\title{
TERRORISM, CRIMINAL LAW AND POLITICS
}

THE DECLINE OF THE POLITICAL OFFENCE EXCEPTION TO EXTRADITION

\author{
Julia Jansson
}
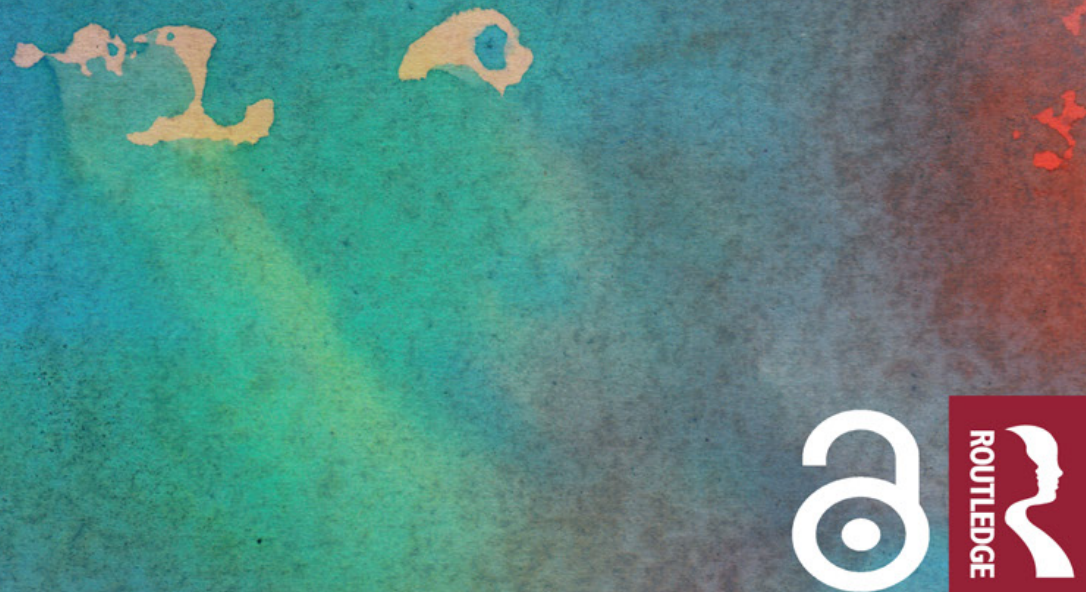


\section{Terrorism, Criminal Law and Politics}

Recent atrocities have ensured that terrorism and how to deal with terrorists legally and politically has been the subject of much discussion and debate on the international stage. This book presents a study of changes in the legal treatment of those perpetrating crimes of a political character over several decades. It most centrally deals with the political offence exception and how it has changed. The book looks at this change from an international perspective with a particular focus on the United States. Interdisciplinary in approach, it examines the fields of terrorism and political crime from legal, political science and criminological perspectives. It will be of interest to a broad range of academics and researchers, as well as to policymakers involved in creating new anti-terrorist policies.

Julia Jansson holds a Doctor of Laws degree from the University of Helsinki, Finland. 


\section{Transnational Criminal Justice}

The concept of 'transnational criminal justice' has frequently been interpreted in the academic literature as 'international criminal justice' or 'global criminal justice.' Many publications that use the term 'transnational' therefore discuss international criminal justice and international legal frameworks. Another form of study that has developed under the umbrella of transnationality in the field of criminal law is comparative. There has hence been a move from the terminology of 'international,' 'global' and 'comparative' criminal justice towards 'transnational' criminal justice.

This series considers these developments, but focuses primarily on publications that adhere to a more literal interpretation of the term 'transnational.' The aim of the series is to provide a forum for discussion of bilateral and multilateral relationships between nations in the field of criminal justice. International law influences these relationships but is not the focus here. Equally, to explain transnational relationships, comparative analyses are required. While incorporating comparative studies in this series, the aim is the explanation of challenges to criminal justice cooperation in bilateral or multilateral relationships.

\section{Series Editor}

Saskia Hufnagel, Queen Mary University of London, UK

\section{Titles in this series:}

\section{Police Cooperation and Sovereignty in the EU}

Norway's Lessons for Europe

Synnøve Ugelvik

\section{Criminal Networks and Law Enforcement}

Global Perspectives on Illegal Enterprise

Saskia Hufnagel and Anton Moiseienko

\section{Terrorism, Criminal Law and Politics}

The Decline of the Political Offence Exception to Extradition Julia Jansson

For more information about this series, please visit: https://www.routledge.com/Transnational-Criminal-Justice/book-series / TRANSCJ 


\title{
Terrorism, Criminal Law and Politics
}

The Decline of the Political Offence Exception to Extradition

\author{
Julia Jansson
}


First published 2020

by Routledge

2 Park Square, Milton Park, Abingdon, Oxon OXI4 4RN

and by Routledge

52 Vanderbilt Avenue, New York, NY 10017

Routledge is an imprint of the Taylor \& Francis Group, an informa business

(c) 2020 Julia Jansson

The right of Julia Jansson to be identified as author of this work has been asserted by them in accordance with sections 77 and 78 of the Copyright, Designs and Patents Act 1988.

The Open Access version of this book, available at www.taylorfrancis. com, has been made available under a Creative Commons AttributionNon Commercial-No Derivatives 4.0 license.

Trademark notice: Product or corporate names may be trademarks or registered trademarks, and are used only for identification and explanation without intent to infringe.

British Library Cataloguing-in-Publication Data

A catalogue record for this book is available from the British Library

Library of Congress Cataloging-in-Publication Data

Names: Jansson, Julia, author.

Title: Terrorism, criminal law and politics / Julia Jansson.

Description: Abingdon, Oxon; New York, NY: Routledge, 2019. |

Series: Transnational criminal justice | Based on author's thesis (doctoral - Helsingin yliopisto, 2018) issued under title: The death of the freedom fighter: how the threat of terrorism is suffocating the protection of political criminals. | Includes bibliographical references. Identifiers: LCCN 2019013170 | ISBN 9780367189044 (hb) | ISBN $9780429199110(\mathrm{eb})$

Subjects: LCSH: Terrorism (International law)-Political aspects. Terrorism-Prevention-Law and legislation. | Political crimes and offenses. | Extradition.

Classification: LCC KZ7220 .J36 2019| DDC 345/.02317-dc23

LC record available at https://lccn.loc.gov/2019013170

ISBN: 978-0-367-18904-4 (hbk)

ISBN: 978-0-429-19911-0 (ebk)

Typeset in Galliard

by Deanta Global Publishing Services, Chennai, India 


\section{Contents}

Abbreviations viii

Key concepts ix

Acknowledgements $\quad \mathrm{x}$

1 Introduction 1

1.1 A bistorico-legal approach 2

1.2 Structure of the book 7

2 Concepts employed

2.1 Political crime and terrorism 9

2.1.1 Defining political crime 9

2.1.2 Classifying political crime 15

2.1.3 Terrorism: the problem of definition 16

2.1.4 Ideologically motivated acts 20

2.1.5 Terrorism as uncivil disobedience 29

2.1.6 Terrorism as an international crime 34

2.1.7 The de-and repoliticisation of terrorism 36

2.2 Extradition: legal and diplomatic function 40

2.2.1 Reciprocal legal assistance 40

2.2.2 Extradition and human rights protections 44

2.2.3 POE versus political refuge: different legal constructions 50

2.2.4 History of the extradition of political criminals 54

2.2.5 Who is a political offender? Four tests 56

2.2.5.1 The UK: the political incidence test 57

2.2.5.2 The US application of the incidence test:

In re Ezeta 189459

2.2.5.3 Evaluating the incidence test 62

2.2.5.4 The French injured rights theory 65

2.2.5.5 The predominance test 66

2.3 Conclusion 69 
3 The rise and decline of romantic liberalism: From the 1800 s to the 1960s

3.1 The emergence of the political offence exception in the 1830s 71

3.1.1 Revolution as evolution 71

3.1.2 POE becomes widely accepted 77

3.1.3 Exception to the exception: the attentat clause of 185685

3.1.4 Four reasons behind the political offence exception 91

3.2 The anarchist threat at the turn of the 20th century 95

3.2.1 Crime against the whole humankind 95

3.2.2 A world without rules: a political goal 96

3.2.3 The depoliticisation of anarchism in 189898

3.2.4 Why was anarchism depoliticised? 104

3.2.5 The 1937 convention 105

3.3 Conclusion 108

4 Taking the political out of the political: 1960s-1980s

4.1 Terrorism challenges the political offence exception 110

4.1.1 Gradual changes in US extradition treaties 1960s-1970s 110

4.1.2 The new revolutionary wave and the US draft convention of 1972113

4.1.3 Politics overrule legal concerns 1970s-1980s 117

4.1.4 Interpol's incapability towards terrorism 121

4.1.5 Terrorism alerts Europe in the 1970s 123

4.1.6 The Iranian hostage crisis provokes a global reaction in 1979131

4.2 Reagan, Thatcher and the narrowing of the exception in the 1980s 133

4.2.1 Legislative war against terrorists 133

4.2.2 Eain v. Wilkes of 1980 as a departure from the incidence test 133

4.2.3 Terrorism starts to affect the US in the 1980s 137

4.2.4 The POE loses its justification 142

4.2.5 US-UK controversies with regard to terrorism in the 1980s 146

4.2.6 Creation of the Supplementary Treaty of 1985151

4.2.7 Evaluating the 1985 treaty 154

4.3 Conclusion 159 
5 Dedication to the fight against terrorism since the 1990s

5.1 Changes in global views on terrorism 161

5.1.1 A new understanding of terrorism in the United States 161

5.1.2 Interpol adopts a new take on terrorism since the 1980s 168

5.1.3 The UN and terrorism as unacceptable violence 172

5.1.4 Why was terrorism depoliticised? 181

5.2 Dismantling the political offence exemption 186

5.2.1 Terrorism as an 'evil ideology' since 2001186

5.2.2 The EAW of 2004 and the annibilation of the POE 188

5.2.3 The POE in modern days 194

5.2.4 Applying the POE in the 2000s 198

5.2.5 "Ballot rather than the bomb": fixing the POE 201

5.3 The repoliticisation of terrorism 211

5.3.1 Do bad motives make worse criminals? 211

5.3.2 Do terrorists have human rights? 214

5.3.3 A threat to democracy 221

5.4 Conclusion 223

6 Conclusion: Protecting political offenders: pipe dream of romantic liberalism?

6.1 The demise of the political offence exception 225

6.2 The delegitimisation of terrorism 228

6.3 Final questions 230

7 Summary

8 Sources and bibliography

Appendix 


\section{Abbreviations}

$\begin{array}{ll}\text { BIA } & \text { Board of Immigration Appeals (USA) } \\ \text { CAT } & \begin{array}{l}\text { UN Convention Against Torture and Other Cruel, Inhuman } \\ \text { or Degrading Treatment or Punishment }\end{array} \\ \text { CPT } & \begin{array}{l}\text { European Committee for the Prevention of Torture and } \\ \text { Inhuman Treatment or Punishment of the Council of Europe }\end{array} \\ \text { ECHR } & \text { European Convention of Human Rights } \\ \text { ECST } & \text { European Convention on the Suppression of Terrorism } \\ \text { EEC } & \text { European Economic Community } \\ \text { ETA } & \text { Euskadi Ta Askatasuna (Basque separatist and nationalist } \\ & \text { organisation) } \\ \text { ETS } & \text { European Treaty Series } \\ \text { EU } & \text { European Union } \\ \text { FLN } & \text { Front de Libération Nationale (France) } \\ \text { FLNC } & \text { Fronte di Liberazione Nazionalu Corsu (Corsica) } \\ \text { FRG } & \text { Federal Republic of Germany } \\ \text { GMT } & \text { Multidisciplinary Group on International Action against } \\ & \text { Terrorism (EU) } \\ \text { ICCPR } & \text { International Covenant for Civil and Political Rights } \\ \text { IHL } & \text { International Humanitarian Law } \\ \text { IHRL } & \text { International Human Rights Law } \\ \text { Interpol } & \text { International Criminal Police Organisation } \\ \text { NSA } & \text { National Security Agency (USA) } \\ \text { PIRA } & \text { Provisional Irish Republican Army } \\ \text { PLF } & \text { Palestinian Liberation Front } \\ \text { PLO } & \text { Palestinian Liberation Organisation } \\ \text { POE } & \text { political offence exception } \\ \text { UDHR } & \text { Universal Declaration of Human Rights } \\ \text { UN } & \text { United Nations } \\ \text { UNHCR } & \text { United Nations High Commissioner for Refugees } \\ \text { UN GA } & \text { United Nations General Assembly } \\ \text { UN GA RES } & \text { United Nations General Assembly Resolution } \\ \text { UN SC } & \text { United Nations Security Council } \\ \text { UNTS } & \text { United Nations Treaty Series }\end{array}$




\section{Key concepts}

Attentat clause - A clause in extradition treaties limiting the application of the political offence exception (POE) so that it does not cover attacks against the lives of heads of state. There are different variations to the clause, some of which cover, for instance, attacks against public officials.

Multilateral treaty clause - Limitation to the POE according to which crimes that one of the parties to the treaty has a duty to extradite or prosecute, as a result of their obligations under the multilateral treaties they are party to, are not considered political offences.

Discrimination clause - Limitation to extradition treaties stating that the party may refuse the extradition request, should they evaluate that the fugitive could not receive a fair trial in case of extradition due to, for instance, their race, political or religious opinions or sexual orientation.

Political offence exception (POE) - A clause commonly used in extradition treaties that allows the requested state to deny the extradition of the fugitive should they consider that the offence for which the request was made was a political offence. The formulations of the exception vary. 


\section{Acknowledgements}

The current study is based on my PhD thesis, which I defended on 9 June 2018. The seed for this project was, however, already planted in 2006 when I first got interested in the work of the International Criminal Police Organisation (Interpol).

Through the years, I have met countless people who have given me their time and knowledge and assisted me in understanding the details of the problems I was researching. People have pushed me and cheered me when the project seemed too much to handle, and assisted me in moving forward by providing opportunities and introducing me to new contacts.

I wish to especially thank Professor Christopher L. Blakesley and Dr Saskia Hufnagel for their invaluable help in finalising this project. They have both been incredibly flexible and supporting. I could have not wished for better guidance! Thank you, Professor Jukka Kekkonen, for acting as my thesis supervisor and general supporter and for enabling amazing opportunities. I also wish to thank my personal mentors in the field of research, Professor Philip Stenning and Dr Tuija Hietaniemi. I have learned so much from you both. In addition, an important thanks goes to the Emil Aaltonen Foundation, the Finnish Cultural Foundation and the Kone Foundation, all of which have enabled me to properly concentrate on this project.

Finally, thank you to my family and friends, including all the amazing people I have met along the way at the Finnish Institute of International Affairs, the Faculty of Law at the University of Helsinki and the Centre of Excellence in Policing and Security at Griffith University in Australia.

I wish to dedicate this book to my Mum, Pirkko Jansson, who accidentally managed to inspire me to study legal issues. 


\section{Introduction}

"Terrorism has nothing to do with politics." This statement was made by an esteemed lawyer specialising in international law, as a reaction to a presentation I held on the political nature of terrorism. Even if this lawyer had an expert view on the topic and some very good reasons to make that claim, their opinion did not alter the starting point of this book, which is opposite to theirs. This book argues that terrorism is, indeed, in all its atrocity, a political act. In fact, its political nature has motivated a widespread attempt to depoliticise it, to label it 'common' criminality. Why? To facilitate international collaboration against it, to inhibit the treatment of terrorists as 'freedom fighters,' to simplify the extradition of terrorists and to remove any justification to atrocious violence.

For a long time, terrorists were treated as political criminals. Even now, as Professor Jan Klabbers has pointed out, "international law has great difficulty in deciding whether terrorists should be treated as ordinary criminals or as political actors." This book argues that this difficulty strongly relates to the so-called political offence exception to extradition (POE) protecting political offenders from extradition. This principle has been used in the vast majority of (Western) extradition treaties since 1834 .

Soon after the POE was created, it became obvious that it could also be used to protect, in addition to offenders fighting for legitimate causes, violent criminals struggling for unwanted political goals. For this reason, it was soon restricted with the so-called attentat clause. Until the emergence of the modern terrorist threat in the 1970s, other limitations to the exception were, however, rare. ${ }^{2}$ Gradually, the restrictions grew in number to cover specific types of serious criminal methods often used by terrorists. For instance, several United Nations (UN) antiterrorism conventions, the 1977 European Convention on the Suppression of Terrorism and the 1985 US-UK Supplementary Extradition Treaty limited the POE in order to exclude terrorists from its protection. When this reactive strategy proved inefficient, debates concerning the annihilation of the exception arose.

1 Klabbers, 2003, 299.

2 Certain war crimes and genocide were already excluded from the scope of the protection of the POE in 1948 and 1949. 


\section{Introduction}

Finally, with the coming into force of the European Arrest Warrant in 2004, the political offence exception has ceased to exist within Europe. It remains to be seen whether this will happen worldwide.

It is argued in this study that this deadly blow to the political offence exception has been a reaction to the modern threat of international terrorism and that it can have implications also for non-violent offenders. The liberal idea that emerged soon after the French Revolution, according to which political dissidents, regardless of their political views, deserve protection, has all but ceased to exist amongst Western countries. This has been a result of the collision of practical problems and an acute sense of threat, with democratic ideals and the rule of law.

The rise of the terrorist threat during the last decades, the international depoliticisation of terrorism and the changes in the political offence exception to extradition from the 1830s until 2004 all go hand-in-hand. Perhaps surprisingly, concurrently with these trends, terrorism has been repoliticised in the national legislation of several countries. This book contextualises these seemingly contrasting developments and the political reasons behind them and analyses their implications. One of the core threads of the study is to examine how the US has affected these changes.

It is the intention of this work to encourage a discussion on the motives of terrorism as well as on the impetus resulting in the creation of the POE. The key argument put forward in this study is that the POE forms a part of the inheritance of the rise of liberalism and should be protected as such. The original aim of the POE was to protect those fighting for the liberal cause and this motivation should be acknowledged when applying the exception. Further, violent terrorists do not deserve the protection of the exception and they should be excluded from it. Such an exclusion will only be possible if terrorism is defined internationally. For this purpose, this book presents a working definition of terrorism. The definition acknowledges that terrorists have political motives.

\subsection{A historico-legal approach}

Western nations have been fighting terrorism in one way or another since the late 1800s. Starting from the early years of the 21 st century, it has been one of the focus points of global criminal and security policies. Because the phenomenon has relatively long historical roots, it is both important and interesting to contextualise it. This book presents a thorough analysis of a vast number of historical sources and demonstrates the important changes in how terrorism has been dealt with. It also highlights some intriguing historical analogies.

The scope of the research extends to a period of nearly 200 years, from 1834 to 2004. The choice of the time period covered is based on some of the initial findings of the research. The natural starting point emerged from the introduction of the political offence exception into extradition treaties in 1834. The ending point is more debatable. The choice is based on a key conclusion of the research: the year 2004 can arguably be seen as a closure for an era which I have 
named the era of romantic liberalism vis-à-vis political offenders. ${ }^{3}$ That year, the POE was effectively eliminated within European Union (EU) member states. In part, the discussion of the study extends beyond 2004 to illustrate more recent developments, but does not focus on creating a systematic analysis of this more recent period.

The study focuses on legal developments within a historical and international political context. The main research questions are "How and when did the current trend of depoliticising terrorism emerge?" "How did terrorism affect the political offence exception to extradition?" and "Why did these changes occur and what are their implications?" With an academic background in political history, I position myself in the field of social sciences even when researching legal topics. This position that integrates divergent fields is fruitful, but naturally, also comes with weaknesses. Some detail is always lost in research that covers a lengthy period of time and is a crossover of different academic fields. However, this study provides a comprehensive historical view and a unique analysis of the themes covered, and as such, it fills a clear gap in existing research.

In order to tackle some of the most fundamental questions that relate to the study of terrorism, I have adopted a critical strategy to the study of terrorism, following Professor Philip Jenkins's ideas. If terrorism is understood as a phenomenon that has "nothing to do with politics," as presented at the beginning of this chapter, the solutions to the problem will look very different to those that are used if terrorism is understood as an inherently political phenomenon.

The analytical method chosen for the purposes of this study is historical and source-critical. Legal changes are contextualised by analysing political developments that have led to them. The research has been inspired by the writings of Judith N. Shkar ${ }^{4}$ and the idea of the law as something functioning within a society, never completely neutral and free of political and moral considerations. Legal changes do not emerge in a separate 'bubble,' but are intertwined and linked with political and social developments. ${ }^{5}$ As a result, legal materials offer a viewpoint to issues that are inherently political, such as terrorism. This book argues that terrorism, as a subject of policy- and lawmaking, is indeed a political phenomenon. Sometimes, however, terrorism has been constructed as a non-political issue; in other words, depoliticised. ${ }^{6}$ Because of this interpretation, a constructionist approach to the theme is useful for the purposes of analysis and for the purposes of selecting the relevant sources.

The interest of this study lies in analysing the ways in which the political offence exception and terrorism as legal constructions have changed since their creation and in examining the political motivations to these changes. According to Jenkins, terrorism has been a flexible problem that has been convenient to

3 See Chapter 3, Section 3.1.1 for a definition of romantic liberalism.

4 See especially Shkar, 1986.

5 See e.g. Kekkonen, 2013.

6 The concept of depoliticisation is discussed in more detail in Chapter 2, Section 2.1.8. 
different interest groups and political causes. ${ }^{7}$ The construction of the terrorist problem during different times and its labelling as political or non-political relates to wider political goals.

The sources used in this study are international treaties, conventions and resolutions, as well as political recommendations. It covers a vast amount of bi- and multilateral extradition treaties and offers an extensive view on the language used in them and their evolution. The viewpoint is global with a special emphasis on the US to enable a systematic analysis of the developments in extradition treaties. In addition, US treaties are compared with some key French and UK extradition treaties. Almost all US extradition treaties are accessible online, ${ }^{8}$ which has facilitated the creation of an analysis that covers the time period from the emergence of the POE to modern days.

The focus on the US can be justified because, according to Boister, it has, during the last century, used its national legislation as a model for new treaties, thus affecting law reforms around the world. ${ }^{9}$ There are significant similarities between extradition treaties, even across civil and common-law systems, as noted by Geoffrey Gilbert. It is typical for courts even to refer to decisions from a different jurisdiction. Provisions regarding extradition in domestic legislations also typically bear resemblance as domestic laws often reflect international treaty provisions. For these reasons, an analysis of even an individual state practice can be meaningful and relatively comprehensive. ${ }^{10}$

Further, the wider diplomatic role of the US in the world since the Second World War is incontestable. It has been one of the leading agents in the international fight against terrorism and played a key part in the UN and Interpol, two organisations that have made considerable efforts in the battle against terrorism. Based on previous research on Interpol, ${ }^{11}$ it was possible to begin with the hypothesis that change in the US's take on terrorism also changed how it was approached by Interpol and that this, in turn, had a noticeable effect on the organisation. The present book deliberates this claim further and elaborates on it.

In addition to the US, the research focuses on Western European states. With a relatively long history of dealing with terrorism, European states such as France and Italy serve as interesting examples. The focus on Western states solely can, naturally, be criticised, and it is clear that there is a lot of room left for research on how non-Western states have viewed terrorism. Specific cases of interests would be Brazil, China and Russia. However, within the confines of a single book, the selection of these two points of focus can be justified.

7 Jenkins, 2003, 189.

8 Although not on one specific site. I have searched them using various search engines including the United Nations Treaty Collection, treaties.un.org (Retrieved 18 October 2018).

9 Boister, 2015, 22.

10 Gilbert, 1991, 1-2.

11 See Jansson, 2008. 
The study does not provide an extensive analysis of the developments of definitions of terrorism in domestic laws. This is because the main interest of the current research lies in antiterrorism tools that concern international relations between states, and not so much each state's internal affairs. In other words, the focus is on how the political nature of terrorism has been understood in the international field. Some national laws are, however, referenced for demonstrative purposes.

In addition to extradition treaties, key research material includes UN Security Council and General Assembly counterterrorism resolutions, UN conventions that relate to terrorism, Interpol antiterrorist resolutions, and different European policy and legal documents, including the Council of Europe documents. ${ }^{12}$ This choice of sources provides a wide set of data starting from the early 1800s until 2004.

The value of official documents for the purposes of a historical analysis can be criticised. According to Gilbert, "Indeed any analysis of transnational terrorism and fugitive offenders based simply on treaty provisions alone is prone to this limited vision of State aims and objectives. The provisions have to be seen in the context of their application and of other measures designed to achieve similar ends." ${ }^{13}$ However, as the interest of this study does not lie in the application of the resolutions and recommendations but in analysing their intention, the choice can be validated. The aim is to build a picture of how terrorism has been viewed and how the (perceived) intensification of the problem has affected decision-making. In other words, the study presents how the terrorist problem has been constructed internationally and how this, in turn, has affected other legal constructions.

Official documents such as treaties, conventions and laws, in general, portray the 'accepted version.' The wording in internationally drafted official documents made for public use, such as Interpol resolutions and UN treaties, is a result of countless hours of diplomatic debates and discussions. As such, they represent a 'global compromise' on terrorism. The same is true for European documents, just in a narrower context. UN resolutions are given by the Security Council (SC) and the General Assembly (GA). The GA's resolutions are recommendatory. These resolutions become legally significant when they are recited and copied into other international instruments. ${ }^{14}$

The sources have been selected with the aim of offering different points of view to the same topic: the texts formulated by the UN are a highly authoritative source in international law; international antiterrorist conventions are legally

12 The choice of documents has been aided by three key works by international law scholars: Noone and Alexander, 1997; Bassiouni, 2001; and Saul, 2011.

13 Gilbert, 1998, 289.

14 See e.g. Bassiouni, 2001. It is noteworthy that it has been argued that the Security Council's role since 2001 has been quasi-legislative in nature as it has been invoking binding obligations to the legislators of member states. See Sambei, Du Plessis and Polaine, 2009, 21. 


\section{Introduction}

binding to those states that have ratified them; resolutions by Interpol offer a law enforcement-oriented view on terrorism; US extradition treaties point to changes in US policies and interests during the studied period, and European documents point to a growing mutual trust amongst European states. The Council of Europe's recommendations and resolutions are also non-binding but their political role is of importance. They are particularly interesting because the Council of Europe concentrates on human rights issues, democracy and the rule of law, all of which are issues that can become highly complicated when dealing with terrorism. An emphasis on them often generates a heated debate on the question of whose rights are more important: those of the terrorists or those of the (potential) victims. A compromise where both parties' rights could be protected seems to have been considered a utopian option.

With the help of the described data set, it is possible to do meaningful basic research on the development of the political offence exemption and of the treatment of terrorism internationally. Presented also is a table ${ }^{15}$ compiling detailed information on US extradition treaties over the years.

The present research is, first and foremost, a political history study that uses legal materials to analyse, explain and portray wider political changes. However, it communicates with a variety of divergent fields, including international and criminal law, political science, legal and political history, and the sociology of law. At the core of this study lies extradition law which is, in itself, an interesting mix of legal and diplomatic issues and as such necessitates a multi-disciplinary approach.

This study aspires to follow the footsteps of scholars who have previously successfully merged two or more of these fields in order to create new knowledge. In the field of international law, M. Cherif Bassiouni's extensive research cannot be bypassed. ${ }^{16}$ Bassiouni has, for instance, brought light to the political offence exception, to irregular rendition processes and to terrorism. Extradition law and the political offence exception have also been a focus of other well-known scholars such as Christopher L. Blakesley, Geoffrey Gilbert, Manuel R. García Mora and Christopher H. Pyle. Pyle's book Extradition, Politics and Human Rights touches upon many of the themes in this study but concentrates on the development of US legislation. The aim of this present book is to complement Pyle's thorough work by introducing a comparative international perspective to the US legal sources that Pyle used, as well as by setting the developments presented by Pyle into the wider context of depoliticisation.

Political crime and the political offence exception cannot be discussed without making a reference to the 1980 book The Political Offence Exception to Extradition: The Delicate Problem of Balancing the Rights of the Individual and the International Public Order by Dr Christine van den Wijngaert. ${ }^{17}$ Van den Wijngaert has pointed to the complexity of the POE with regard to violent inter-

15 See Appendix.

16 See e.g. Bassiouni, 1969, 1973, 1987; and Bassiouni and Wise, 1995.

17 Van den Wijngaert, 1980. 
national criminals whose deeds seem to threaten the very basis of democracy. However, Van den Wijngaert finalised her book close to 40 years ago and many events have since significantly affected the POE.

Political crime as a phenomenon has been a subject of scholarly work especially during the 1960s and 1970s. During this era, the magnitude of the current terrorist threat was still unimaginable, but the idea of political criminals as a more noble class of criminals started to fade out. Concurrently with the rise of international terrorism, interest in the political offence exception amplified and judicial responses to terrorism grew in number. However, since this period, less attention has been paid to the concept of political crime and its relationship with terrorism, in particular. One of the key scholars in this field today is Jeffrey Ian Ross, who has written comprehensive books on the matter. ${ }^{18}$

In dealing with the concept of the political in a wider sense, this study builds a dialogue with German jurist and political scientist Carl Schmitt. In particular, his ideas on the concept of the political are an interesting starting point when discussing the political nature of terrorism. ${ }^{19}$ The contribution of the present book to the debate on the definitions of terrorism could not have been done without Alex P. Schmid's work on the definitions of terrorism. ${ }^{20}$ Also, Ben Saul's massive opus on terrorism, alongside his other research on international law, has served as an important stepping stone. ${ }^{21}$ Further, Mathieu Deflem's research on the depoliticisation of terrorism and Interpol have been major sources of inspiration for this study. ${ }^{22}$

Additionally, the historical foundation for the analysis lays on a wide variety of historical scholarship providing knowledge and understanding of the most important political changes that can be linked to the motivations behind the limiting of the POE as well as the de- and repoliticisations of terrorism.

\subsection{Structure of the book}

This book is mostly built on a chronological structure. Following this introductory chapter, the second chapter offers a critical and historical discussion on the rather complex concepts that are used for the purposes of analysis throughout the research. It argues that terrorism falls into the category of so-called relative political crimes, which are 'common' crimes committed for political purposes. It further discusses the concepts of depoliticisation and offers a condensed view on extradition and the political offence exception to extradition.

The third chapter of the book concentrates on the period starting from the aftermath of the revolution of 1830 in France. During this period, discussed

18 Ross, 2003 and 2012.

19 Schmitt, 1996 (1932).

20 Schmid, 1984, 2004, 2011; Schmid et al., 1988.

21 Saul, 2012.

22 E.g. Deflem, 2002, 2004, 2005 and 2006. 
under the title "The rise and decline of romantic liberalism: from the 1800 s to the 1960s," the so-called political offence exception emerged. The chapter presents the underlying political motivations for the creation of the exception and the first political controversies it sparked in Europe, especially in relation to the protection of political assassins and anarchists. It suggests that the exception was created in the spirit of romantic liberalism in an era of political turmoil in Europe. The chapter ends with a discussion on the League of Nations anti-terrorist convention of 1937, which was created as a result of political alarm caused by terrorist attacks in Europe. The attempt to create a comprehensive convention, however, failed, and the Second World War pushed concerns regarding terrorism to the side.

The second historical period covered is the period after the Second World War until the final decade of the Cold War when the terrorist threat started to resurface on the global security policy agenda. This period is discussed in Chapter 4, "Taking the political out of the political: 1960s-1980s." This era witnessed the first international terrorist attacks that received wide publicity. The US and the UN made attempts to create new comprehensive conventions that would have defined terrorism and joined the world in the fight against it. However, this process failed due to a number of difficult political considerations. The chapter demonstrates that this led to the choosing of a seemingly new strategy; gradual limitations to the POE; and a piecemeal approach to criminalising specific terrorist deeds, which essentially meant the depoliticisation of terrorist acts by separating them from their motivations. This development culminated in the US-UK Supplementary Treaty of 1985, which excluded all violent acts from the protection of the POE and related to the rise of the global terrorist threat as well as of conservatism in both countries.

The third period starts from the beginning of the 1990s when it became clear that the growth of the terrorist threat was not a passing phenomenon and that the US could no longer see itself as separate and protected from global events. These developments are discussed in Chapter 5, "Dedication to the fight against terrorism since the 1990s." The chapter analyses the process where the West started to openly consider terrorism a global threat and the political nature of the phenomenon was pushed to the side. It is argued that the POE that had proved to hinder the fight against terrorism, an inherently political phenomenon, was abolished within the EU in 2004, which also marks the end of the period studied in this book. This chapter also discusses the motivations for the existence of the POE and the implications of its annihilation as well as the reasons behind the chosen strategy of depoliticisation. It further opens a discussion on the repoliticisation of terrorism, which is argued to serve the same purpose as the strategy of depoliticisation.

The contents of the study are brought together in the conclusive Chapter 6, "Conclusion: protecting political offenders - pipe dream of romantic liberalism." This chapter lays out the findings of the study as well as opens up potential for further research. 


\section{Concepts employed}

\subsection{Political crime and terrorism}

\subsubsection{Defining political crime}

This study uses the notions 'political crime' and 'political offence' as synonyms. Both of these concepts have been widely employed in studies of politics and of law, regardless of the lack of definition for either. Defining these concepts is not an easy task, as even the term 'political' seems to evade all attempts at definition. ${ }^{1}$

Otto Kirchheimer has suggested that "something is called political if it is thought to relate in a particularly intensive way to the interests of the community." Understanding the concept in this manner, it is possible to argue that all crime is political. This is true also because all laws portray values and morals in a given society. ${ }^{3}$ Laws come into being as a result of a political decision-making process and reflect the values of those in power in a society.

'Political crime' is not a natural concept, but a political creation in itself. ${ }^{4}$ As Barton L. Ingraham described, political crimes are "acts which officials treat as if they were political and criminal regardless of their real nature and the motivation of the perpetrators. ${ }^{5}$ As a rule of thumb, illegal actions with the intent to oppose the state can be called political crime. ${ }^{6}$

This category of crime has not been accepted in all societies. For instance, England never incorporated the concept into its national legislation, and, as a consequence, the United States never took on the notion. ${ }^{7}$ Ingraham and Tokoro have explained this by the prevalence of the doctrine of legalism in England, reflecting the history and philosophy of the country. Traditionally, the English

1 Knauss and Strickland, 1988, 91.

2 Kirchheimer, 1961, 25.

3 Schafer, 1971, 380.

4 See Kirchheimer, 1961, 26-45 for a detailed account on the development of the idea of political crime.

5 Ingraham, Barton L., Political Crime in Europe: A Comparative Study of France, Germany and England, 1979. Cited in Ross, 2003, 34.

6 See e.g. Garcia-Mora, 1962, 1226.

7 Ferrari, 1920, 308; Ingraham and Tokoro, 1969, 160; Schmid, 1984, 27. 
viewed obedience to laws as a moral necessity. Both in England and the US, the state and the law were seen as the providers of basic protection for the citizens' freedom of expression, including the freedom to express dissenting opinions. ${ }^{8}$ Because the state was the protector of those values, a crime that would gain legitimation from being 'political' could not exist. All crime was 'common' crime. However, such a view did not concern foreign political criminals whose ideologies did not contradict domestic interests. They were treated differently from other criminals. ${ }^{9}$

Many states have been willing to apply the concept of 'political crime,' but, typically, this has been done without giving it a legal definition. The first, and seemingly only, attempt to define political crime within any national law was the German Extradition Law of 1929. It defined political acts as "those punishable offences $[\ldots]$ which are directed immediately against the existence of the security of the State, against the head or a member of the government of the State, as such, against a body provided for by the constitution, against the rights of citizens in electing or voting, or against the good relations with foreign States." The definition has been criticised, especially because it completely excludes crimes committed by totalitarian states against their own citizens. ${ }^{10}$ Some classifications of political crime have, indeed, included 'state crimes,' or crimes committed by the state. ${ }^{11}$ The focus of this study is on oppositional political crime, and for this reason crimes committed by states are ruled out. This is because the main interest in this study is the reactions of the states when opposing oppositional political crime. Oppositional political crimes can further be categorised into two groups: nonviolent and violent crimes. ${ }^{12}$

The concept of political crime can be distinguished from the political use of justice and political trials. These concepts are linked and intertwined, but still form separate categories. Political trials are typically understood as abuses of the legal system for the purpose of furthering political aims. ${ }^{13}$

Otto Kirchheimer has classified political trials into three main categories. ${ }^{14}$ The first category is closely connected to my usage of the concept of political crime. In Kirchheimer's classification, this type of trial concerns common crime

8 Ingraham and Tokoro, 1969, 160. See also Shkar, 1986, 210; and Oppenheim, Jennings and Watts, 1992, 965.

9 McElrath, 2000, 23-24. However, this view changed during the last decades of the 20th century, as discussed in this book.

10 Garcia-Mora, 1962, 1230.

11 Hagan, 1997, 2, 177; Ross, 2003, 5, 38. Whether crimes committed by the state are included in the classification of political crime is under dispute. In Ross's classification, crimes are divided into two groups: oppositional (or anti-systemic) and state (pro-systemic). The first group refers to acts of individuals or groups against the prevailing political force, whereas crimes committed by the state's "criminogenic agencies" (police, military, security forces etc.) against individuals or other governments form the second group. Ross, 2003, 9 .

12 Ross, 2003, 38.

13 Shkar, 1986, 143-151.

14 See also on political trials e.g. Shkar, 1986, 143-151; and Teitel, 2000, 75-77. 
committed for political purposes, aiming at gaining political benefits. In my opinion, terrorism falls into this category, as it indeed has political goals and seeks political effects. I will discuss these claims in more detail in Chapter 2, Sections 2.1.1-2.1.6.

Kirchheimer's second category is the "classic political trial" where the regime aims at discarding its foe by incriminating their behaviour. The third category of political crime is the "derivative political trial, where the weapons of defamation, perjury and contempt are manipulated in an effort to bring disrepute upon a political foe." ${ }^{15}$ Also these two other categories can be linked to the concept of terrorism.

First, 'terrorist' is sometimes used as a label against a person who is considered a danger to the whole society. For instance, Julian Assange, the whistle-blower whose case is discussed in Chapter 5, Section 5.2.4, has sometimes been labelled as a terrorist ${ }^{16}$ even if his actions as the founder and leader of WikiLeaks did not involve any physical violence. ${ }^{17}$ Second, understanding a 'terrorist' deed as a special category of violence allows for it to be treated more severely in a court of law. This idea is linked to my idea of the repoliticisation of terrorism discussed particularly in Chapter 5, Section 5.3.

Interestingly, none of Kirchheimer's categories concern trials for purely political crimes, such as sedition. ${ }^{18}$ It is, however, clear that a trial against someone who has, for instance, committed treason is highly political. Its political nature concerns both the aims and consequences of the crime, as well as the implications of the outcome of the trial. However, as Judith N. Shkar has noted, it is possible, at least theoretically, to have an ordinary criminal trial for a political offence. Nonetheless, she also acknowledges that it is difficult to maintain "judicial calm when the deepest political passions have been aroused." 19

Shkar has also identified three types of political trials. In addition to the aforementioned trial for a political offence bearing resemblance to an ordinary criminal trial, a political trial can also be the conviction of a person for a crime that they have not committed or for an act that has not been classified as criminal in legislation. The latter case contradicts the principle of legality: nullum crimen sine lege. ${ }^{20}$ Third, political trials can be used to strengthen the identity of the ruling power. ${ }^{21}$ The subjects of political trials are the 'other,' against whom the justice

15 Kirchheimer, 1961, 46. According to Kirchheimer, many jurists deny the existence of political trials. Kirchheimer, 1961, 48.

16 Fox News, 30 November 2010, "Yes, WikiLeaks is a terrorist organization and the time to act is NOW"; The Guardian, 19 December 2010, "Julian Assange like a hi-tech terrorist, says Joe Biden."

$17 \mathrm{NB}$ : This statement does not relate to the rape charges against Assange, but merely to his position as the head of WikiLeaks.

18 The division between purely and relative political crimes is discussed later.

19 Shkar, 1986, 150.

20 Shkar, 1986, 152.

21 See Shkar, 1986, 147. 


\section{Concepts employed}

system is used. Political criminals are also the 'others,' who threaten the unity and values of the state. Political trials are useful tools for history-making during a transitional period. With the assistance of trials, it is possible to create a narrative of history that serves to tie a nation together. ${ }^{22}$ For instance, the Nuremberg trial of Nazi war criminals before the International Military Tribunal partly served this purpose. $^{23}$

Political crime, understood as crime against the state, ${ }^{24}$ emerged concurrently with modern state structures. However, the use of the concept in official contexts is a more recent development. It was introduced into the legislation of the majority of Western European countries in the first half of the 19th century. ${ }^{25}$ The term has most commonly been used in relation to extradition, but also to identify crimes that were subject to a special procedure or a special punishment. ${ }^{26}$

Originally, the term 'political crime' had the same legal meaning in both national and international law. In both contexts, naming a criminal deed political resulted in granting preferential treatment to the offender. Since then, the term has been used in different ways in different contexts: (1) the term 'political offence' has had a broader scope in extradition law than in domestic law; (2) the concept 'related' or 'relative' political crimes has only existed in the context of extradition; (3) in extradition law, the same term can be interpreted differently by courts and administrative decision makers; and (4) the exceptions to the political offence exception $(\mathrm{POE})^{27}$ only exist with respect to extradition and are unknown to domestic law. ${ }^{28}$

Internationally, there has been a long-unsolved debate concerning the definition of 'political crime. ${ }^{29}$ A key question is whether common crimes can become political under specific circumstances and, if they can, under which conditions. The answers to these questions vary from country to country. A further complication is caused by the fact that because political offenders typically believe that they are working towards a more pure and higher goal, and illegal means are justifiable

22 Teitel, 2000, 72.

23 See Shkar, 1986, 153-170, for a discussion on the Nuremberg trial as a political trial and on its lack of legalistic grounds. It was set up as a political necessity and for the sake of future political advantage. Whether this was right or wrong depends on one's perspective on the principle of legality. According to Shkar, "Ironically, perhaps, a trial without law, in this instance, was still a closer approximation of justice, more in keeping with legalistic values, than any other course of action." Shkar, 1986, 160.

24 I concentrate my discussion on the concept of political crime to crimes against the state, as explained in the introductory chapter.

25 Ingraham and Tokoro, 1969, 145.

26 Deere, 1933, 247.

27 The POE excludes political crimes from the scope of extradition. The concept will be discussed in detail later.

28 Van den Wijngaert, 1980, 98.

29 See also Schmid, 1984, 20, for a discussion on the term 'political violence,' which raises many similar points that are brought out in this chapter. 
in order to achieve this objective, ${ }^{30}$ the offenders themselves do not always consider their acts illegal. ${ }^{31}$

Most commonly the concept of political crime has been defined in a 'negative' manner by excluding specific crimes from this category. A growing number of crimes, including for instance attacks against the lives of heads of state, war crimes, genocide and finally terrorism, have been labelled as non-political. The exclusion of terrorism from this category is a core interest of this study. International crimes such as war crimes and crimes against humanity covered by the Geneva Conventions are not discussed in detail.

Christine van den Wijngaert, who has done an extensive study on the topic of political crime has written: "['Political offence'] is a comprehensive term encompassing various forms of delinquent behaviour and, as such, it covers a wide range of offences. It can be viewed as a spectrum, with at one end purely passive offences such as political dissidence and on the other active offences of opposition against prevailing social order or against the ruling group in power. It is a continuum of offences in which the political and common elements are more or less represented, rather than a distinct category of crimes which could be distinguished from the 'common offences'." She has also noted that most definitions of a political offence are tautologous, as they use the term 'political' without defining it. ${ }^{32}$

In the strictest reading, only plain political deeds, acts against the state, which do not contain elements of common crime are viewed as political offences. At the other end of the spectrum, the 'political crime' umbrella covers a wide variety of criminal deeds. Most understandings of what 'political crime' is fall between these two extremes. The term can cover crimes that are considered political for an objective reason. These would include, for instance, all crimes committed during the course of political unrest, or all criminal acts that have political consequences, meaning that they have an effect on the 'polis,' the existing socio-political order. It can also cover crimes that are political for a subjective reason, that is all infractions motivated by ideology or politics, as opposed to private interests, such as greed or passion..$^{33}$ In some cases, the pure affiliation of the individual has been sufficient for a crime to be classified as political. For instance, a strong connection with a terrorist group could be interpreted as enough proof of a political motivation of the actions of a person. ${ }^{34}$ Sometimes also acts directly connected with political offences are treated as political offences. ${ }^{35}$ There is no general agreement about what level of 'politicisation' an act must have in order to be considered political. ${ }^{36}$

30 Hagan, 1997, 2, 177-1788; Bassiouni, 2001, 24-26. On justifying the use of violence by terrorists, see e.g. Fletcher, 2006, 906-907.

31 Ross, 2003, 9.

32 Van den Wijngaert, 1980, 96, italics orig.

33 Hagan, 1997, 2; Ross, 2003, 4.

34 Ross, 2003, 5.

35 See in more detail later. Deere, 1933, 248.

36 Oppenheim, Jennings and Watts, 1992, 964. 


\section{Concepts employed}

M. Cherif Bassiouni has suggested that at least three factors must be considered in evaluating a political crime. The first is the involvement and commitment of the actor in the ideology or movement on behalf of which they were acting and their belief for the justification of the means used. Second, the link between the political motive and the crime committed needs to be weighed. The third point that needs to be evaluated is the proportionality of the acts committed in relation to the end sought. ${ }^{37}$

Bassiouni describes "common crimes" as attacks against interests that are shared by organised societies with different social and political views as worth protecting. In contrast, political crimes go against interests that are not common to all societies. The laws that criminalise these acts may vary in time and place. ${ }^{38}$ Similarly, according to García-Mora: "political offence in the courts of one country may be a common crime in those of another." 39

Even if one had a clear definition of political crime, specific cases could still be confusing. Some offences can seem to be political, but after closer scrutiny, they lose that character. A political context does not necessarily make a crime political and circumstances have an effect on how a deed is judged. For instance, the killings of police officers by the Black Liberation Army in the 1970s were treated as political crimes, whereas attacks against police officers by anti-globalisation protesters at the turn of the 20th century were not. ${ }^{40}$ In some cases the intent of a specific act is unclear. Some 'pure' political crimes can be committed for a non-political purpose. An example of this would be acting as a spy for purely financial reasons. ${ }^{41}$ On the other hand, common crimes can also be committed by 'altruistic' motivations. For instance, the motivation for a murder can be to offer euthanasia or as the classic example suggests, food can be stolen in order to feed one's children. ${ }^{42}$

Jeffrey Ian Ross's summarisation of how to recognise political crime follows along the lines of the age-old expression: "If it looks like a duck, walks like a duck and quacks like a duck, then it must be a duck." Further, he continues: "In sum, you can identify a political crime through triangulating among existing laws, the individual's (or group's) motivations, the kind of victim/target attacked, the result and the context of the action." "43 It is clear that such an imprecise definition does and should not suffice for legal purposes. The existence of a concept that continuously has legal implications but lacks a legal definition creates uncertainty and doubt. ${ }^{44}$

37 Bassiouni, 1969, 250. Bassiouni's idea is related to the so-called predominance test, or Swiss test, discussed in Section 2.2.5.

38 Bassiouni, 1969, 229.

39 Garcia-Mora, 1962, 1229.

40 Ross, 2003, 4.

41 Van den Wijngaert, 1980, 30; Ross, 2003, 4-5.

42 Van den Wijngaert, 1980, 31.

43 Ross, 2003, 5.

44 Deere, 1933, 247; Garcia-Mora, 1962, 1226-1227. 
As shown, academics have not agreed upon what political crime is. Drawing the line between political and common crimes becomes even more complicated when the definition becomes a legal or a political question. Christine van den Wijngaert has pointed out that the legal meaning can have concrete ramifications on matters such as the extraditability of a person, whereas the sociological meaning does not have these kinds of implications. ${ }^{45}$

\subsubsection{Classifying political crime}

For analytical purposes, it is useful to separate different types of political crimes. Political crimes are generally classified into two groups. The first is the 'pure' or 'purely' political crimes, which are direct attacks against the political organisation or government of a state. Pure political crimes lack any element of common crime and they do not injure people or cause damage to property. Deeds such as treason, subversion or insurrection fall within this category. ${ }^{46}$

In the strictest interpretation of the political offence exemption, only pure political crimes are considered non-extraditable. This interpretation was vocalised by a French court in the Giovanni Gatti case in $1947 .{ }^{47}$ However, during the time of list-based extradition treaties, pure political crimes were typically never listed as extraditable crimes. ${ }^{48}$

The second group of political crimes is that of 'mixed' or 'relative' political crimes or délits complexes in French. They mix a political/ideological element with a common crime. Mixed political crimes can be, for instance, kidnappings or assassinations committed for an ideological goal. ${ }^{49}$ There are different views on which acts count as relative political offences. Some suggest a relative political offence is one where a common crime is committed in connection to a political act or event. Others consider any common crime with a political motive a relative political crime.

In addition, some have added a third group for classification purposes: that of compound political offences, which are punishable acts combining a purely political offence and a common crime. ${ }^{50}$

The line between a relative political offence and a common crime is not easy to draw. For instance, Van den Wijngaert has defined a political offender as "a person who violates the criminal law on the grounds of his political and ideological convictions. This politico-ideological motivation is the only criterion on which

45 Van den Wijngaert, 1980, 97.

46 See e.g. Deere, 1933, 248; Ingraham and Tokoro, 1969, 146; Bassiouni, 1969, 244-245; Hagan, 1997, 2.

47 In re Giovanni Gatti, 14 ann. Dig. 145 (Cour d'appel, Grenoble 1947). See, in more detail, Section 2.2.5.

48 See also Section 2.2.4.

49 See e.g. Deere, 1933, 248; García-Mora, 1956, 78; Bassiouni, 1969, 244; Ingraham and Tokoro, 1969, 146; Hagan, 1997, 2; Gilbert, 1991, 119; Gilbert, 1998, 215-216.

50 Kälin and Künzli, 2000, 65. 


\section{Concepts employed}

to distinguish political criminals from common offenders and from pseudo-political offenders since there is often no difference between the crimes committed." ${ }^{51}$ In contrast, Bassiouni has criticised the use of the term 'relative' or 'quasi' political offence. He has called them descriptive labels with no judicial value. According to him, the motivation of a crime cannot change its nature. In fact, the focus on the criminal's motive contradicts theories which remove motive from the elements of criminal offences. The element of intent, the mens rea, does not question why a specific act was committed. ${ }^{52}$

If the motivation is understood as the sole factor separating common and political crimes, the line between the two can easily become blurred. ${ }^{53}$ Modern courts typically do not accept that a political motive would suffice in characterising a common crime as political in extradition cases. ${ }^{54}$

The division between pure and mixed political crimes partly follows the traditional classification that divides illegalities into two categories: mala in se and mala probibita, natural as opposed to conventional or statutory crime. Mala probibita refers to classifications of crime that vary according to time and political culture. Mala in se, in turn, represents crimes that are considered condemnable by most nations and across legal systems. Pure political crimes are never mala in se. ${ }^{55}$ Relative political crimes, on the other hand, can be mala in se, that is crimes with a political motive.

Notwithstanding the lack of consensus on the exact meaning of the notion 'political crime,' nearly all states have needed to formulate their own understanding of the phenomenon. This is due to what is called the 'political offence exemption' to extradition. The exemption and its emergence are discussed in detail in Chapter 3, Section 3.1. The classification of specific crimes as political for the purposes of the exception is one of the core themes of this book and thus runs through the whole study.

\subsubsection{Terrorism: the problem of definition}

A study that explores terrorism can never evade the problem of definition. This study focuses on the changes in the way in which terrorism has been understood and dealt with in different times. For this reason, the definitional question is embedded in the research. Hence, this initial conceptual part is merely

51 Van den Wijngaert, 1980, 27, italics added.

52 Bassiouni, 1969, 248-249.

53 "The boundaries become blurred, in instances such as when drug cartels or large-scale criminal organisations use violence against political elites and institutions to exercise control over their chosen domain (drugs, gambling, prostitution). Even in these examples, however, the primary aim of attacking political targets is to safeguard the criminal activity and not to affect the political environment per se." Wight, 2015, 108. See also García-Mora, 1956, 76; Ingraham and Tokoro, 1969, 146; Hagan, 1997, 2; Wight, 2015, 113.

54 Gilbert, 1991, 120.

55 Ferrari, 1920, 308-309. 
preparatory to the wider discussion on the nature of terrorism. The aim of this chapter is to present some of the most widely used definitions of terrorism as well as the problematic nature that lies in trying to create an internationally accepted definition. Finally, it explains my own understanding of the phenomenon and how it should be classified.

The main definitional selection done for the purposes of this study has been to exclude state terrorism from its scope in its entirety even if, it can easily be argued, its human costs have been much higher than those of anti-state terrorism. ${ }^{56}$ The interest of this research lies especially in different states' and international organisations' responses to anti-state terrorism. ${ }^{57}$ Trying to tackle state terrorism in this context would be out of the scope and purposes of this study. Further, state crime is regulated by international human rights law (IHRL) and international humanitarian law (IHL, or the law of armed conflict) and thus forms an entirely different category of crime compared to anti-state terrorism. This does not mean that the state or its individual authorities cannot commit atrocities that amount to terrorism and perhaps should also be labelled as such, but merely that the legal mechanisms that are in place for the purposes of punishing such acts are different to those used against individuals or groups committing oppositional terrorist acts. ${ }^{58}$

Regardless of worldwide counterterrorism efforts and a debate that has been going on for decades, an internationally agreed legal definition of terrorism still does not exist. ${ }^{59}$ For instance, all UN terrorism definitions are diverse. The 1994 Declaration on Measures against International Terrorism defines terrorism as

56 See e.g. Pyle, 1988, 184. The concentration on anti-state violence is, unfortunately, a typical exclusion, done also by scholars researching other forms of political violence than terrorism. See e.g. Schmid, 1984, 22; Bassiouni, 1988, x. Wight has argued that the concept of state terrorism is analytically useless: "I argue that the concept of state terrorism, although it makes intuitive sense, provides no additional purchase on a critique of unacceptable state practices beyond that already covered by international law. Indeed, since there is no agreed international definition of terrorism, then to move certain state practices into the realm of state terrorism effectively leaves those practices outside legal redress. Nothing is gained, and much lost, by talking of state terrorism." Wight, 2015, 15. See also Wight, 2015, 118. The concept is not recognised in international law. Sambei, Du Plessis and Polaine, 2009, 9.

57 It could be argued that the concept of anti-state terrorism is, in fact, not useful, as most acts of terrorism do not actually target the state apparatus but, instead, they attack the general public instead. See Klabbers, 2004, 305.

58 For instance the International Law Commission in its 1991 Draft Code of Crimes against the Peace and Security of Mankind defined international terrorism solely as acts committed by state officials. According to the draft, an international terrorist is "An individual who as an agent or representative of a State commits or orders the commission of any of the following acts: undertaking, organising, assisting, financing, encouraging or tolerating acts against another State directed at persons or property and of such a nature as to create a state of terror in the minds of public figures, groups of persons or the general public." Article 24 , UN Doc. A/46/10, Report of the International Law Commission on the work of its forty-third session (29 April-19 July 1991). Yearbook of the International Law Commission, 1994, Vol. II, Pt. 2, Pt. 2. See also Cassese, 2006, 944.

59 See e.g. Saul, 2005; Young, 2006; Schmid, 2011; Saul, 2012. 
"criminal acts intended or calculated to provoke a state of terror in the general public, a group of persons or particular persons for political purposes," ${ }^{60}$ whereas the Draft Comprehensive Convention on International Terrorism ${ }^{61}$ and the Terrorist Financing Convention ${ }^{62}$ avoid the problem of openly labelling terrorism as 'political,' by referring to the inherently political purposes of listed violent acts: "when the purpose of the conduct, by its nature or context, is to intimidate a population, or to compel a Government or an international organization to do or to abstain from doing any act." These definitions and their relevant details are discussed in the following sections. ${ }^{63}$

The main obstacle for international counterterrorism initiatives and the creation of a shared definition has been the political and ambiguous nature of terrorism. ${ }^{64}$ According to Saul, a debate on how terrorism should be defined will always be a debate on what is meant by concepts describing different types of political violence such as revolution, uprising, guerrilla warfare or war. As the analysis of the different applications of the POE will show, there is no general understanding of which forms of political violence are acceptable ${ }^{65}$ and whether terrorism can, for instance, include deeds committed during armed conflicts against military targets. For this reason, Saul has claimed that "the apparent agreement on the definition of terrorism is still subject to disagreement." 66

Trying to define an act at the same time elusive and highly political is difficult, or possibly even unattainable. As Alex P. Schmid has stated, "definitions generally tend to reflect the political interests and moral judgment (or lack thereof) of those who do the defining." ${ }^{\prime 7}$ Philip Jenkins has underlined the nature of terrorism as a socially constructed concept, which will be understood differently in different times and cultures. ${ }^{68}$ Arguably, this is true of all crimes, as demonstrated by the constant evolution in law making. No law is created in a vacuum free of social and political interests and values, nor should it be. Additionally, all criminal law is established with the intention to send a signal regarding what conduct is unwanted.

60 Part I (3) UN GA Resolution Declaration on Measures to Eliminate International Terrorism, annexed to the Measures to Eliminate International Terrorism, UN Doc. A/RES/49/60, 9 December 1994, italics added.

61 Article 2 (1) (b) Draft Comprehensive Convention on International Terrorism, UN Doc. A/C.6/55/1, 28 August 2000.

62 Article 1 (b) Convention for the Suppression of the Financing of Terrorism [Terrorism Financing], UN Doc. A/54/109, 9 December 1999.

63 Cassese has argued that a customary international consensus of a definition has already emerged, as the resolutions of the UN General Assembly, the Draft Comprehensive Convention, and most national laws and case law take a similar stance on what is to be considered terrorism. Cassese, 2006, 935-957.

64 See e.g. Nuotio, 2006, 1002.

65 Saul, 2006, 5.

66 Saul, 2015, 400 .

67 Schmid, 2011.

68 Jenkins, 2003, ix. 
The classical dilemma and one of the most commonly used opening phrases of terrorism-related studies is “one man's terrorist is another man's freedom fighter." This saying has been confirmed by some and pronounced useless or purely wrong by others. For instance, Jenkins has provocatively argued that "terrorists can succeed - though if they do, we call them 'Mr. Minister' or 'Your Excellency,' rather than terrorists." ${ }^{69}$ If a party gains power, it is more likely that the atrocities they might have committed prior might be forgotten.

Some have attempted to make a definitional distinction between terrorists and 'freedom fighters.' For instance, Allan has claimed that there is a clear difference between the two: "When violence is directed at symbols of a government in power by those whose stated aim is to overthrow, then the violence is a revolution. If the violence is aimed at civilians and civilian property, then the violence is terrorism."70 This clear-cut division has been challenged, and many would agree that, for instance, killing a policeman, on or off duty, may be seen as an act of terrorism. ${ }^{71}$ In addition, the point about the policeman also represents the problem in categorically defining who is a civilian and who is not.

Some have pronounced the entire concept of terrorism dead and analytically useless. Some have, in turn, argued that the prevention and suppression of terrorism have been unsuccessful partly because there is not enough understanding of terrorism or a consensus on how it should be defined. ${ }^{72}$

Even if no internationally accepted legal definition of terrorism exists, many international legal obligations are tied to the use of the concept. Nations have agreed to implement measures against terrorists, without a joint understanding of what the concept means. ${ }^{73}$ Conventions and laws refer to terrorism without defining it creating uncertainty and doubt. For this reason, the lack of definition is a potential source for violations of human rights. ${ }^{74} \mathrm{~A}$ definition of terrorism would create a legal standard which would prevent, at least in part, the random use of the concept and political abuses of the term ${ }^{75}$ and impede the use of the concept as a mere synonym for "evil." 76 It has been pointed out that some national laws have actually defined terrorist offences in a manner that contradicts international human rights law. ${ }^{77}$

Without an international definition of terrorism, each country is able to use the concept for its own purposes, sometimes for oppressing non-violent political protests. Further, if terrorism is not defined, a very broad understanding of

69 Jenkins, 2003, 81 .

70 Allan, 1993, 329.

71 See also e.g. Fletcher who discusses government targets as targets of terrorist acts. Fletcher, 2006, 903-905.

72 See e.g. Bassiouni, 1975, xi; Schmid, 1992.

73 Saul, 2006, 5.

74 See e.g. Saul, 2006, 5, 50; Sambei, Du Plessis and Polaine, 2009, 15; Wight, 2015, 97.

75 Saul, 2006, 22.

76 Saul, 2006, 68.

77 Saul, 2015, 403. 
it may prevail. As a result, it will remain unclear which forms of resistance are legitimate when facing political oppression. 'True revolutionaries' or innocents can be silenced by using the terrorism label. ${ }^{78}$ Additionally, according to Ben Saul, the criminalisation and defining of terrorism internationally would demonstrate the condemning and the stigmatisation of offenders by the international community. ${ }^{79}$

Despite all the problems relating to the concept of terrorism and the lack of a definition, the concept continues to be used. The persistent application of such a debated notion, even if possibly due to the absence of a viable alternative, suggests that the term seems to be applicable in describing or denoting an existing social phenomenon. ${ }^{80}$

The lack of a shared understanding of the concept is highlighted when the term terrorism meets another concept that has not been defined internationally: that of political crime. As discussed in length throughout this study, there is a strong connection between the definition of terrorism and the so-called political offence exception to extradition. Without a solid and widely accepted definition of terrorism, it cannot be properly excluded from the scope of those political offences traditionally protected from extradition. Further, it is problematic that laws are, as a rule, expected to be precise and predictable, but this principle has been applied neither for political offences nor terrorism.

\subsubsection{Ideologically motivated acts}

Is it possible to claim that terrorism is political, even if there is no accepted definition declaring it as such and there is an international trend of depoliticising it? According to Carl Schmitt, "Every religious, moral, economic, ethical or other antithesis transforms into a political one if it is sufficiently strong to group human beings effectively according to friend and enemy." ${ }^{81}$ Using this view as a starting point, it becomes clear that terrorism is a political phenomenon and notion. Terrorism divides people, and terrorists are often described as enemies (of the whole mankind, hostis humani generis). ${ }^{82}$ In fact, terrorism is a value-laden concept and it is only used against one's political opponents. ${ }^{83}$ As Philip Herbst puts it, the label terrorist conveys "criminality, illegitimacy and even madness." 84

78 DeFabo, 2012, 69-70, 92-94.

79 Saul, 2006, 7, 21.

80 Duyvesteyn, 2004, 440 .

81 Schmitt, 1996 (1932), 37. See in more detail, Schmitt, 1996 (1932), 37-45.

82 Saul, 2006, 21.

83 The term, for instance, has been used by China against the Uighur separatist minority, by Russia against the Chechen rebels, by India against the militants in Kashmir, by Indonesia against the insurgents in Aceh and West Papua, by Nepal against the Maoists and by Morocco against the Islamists, just to name some cases. Saul, 2006, 50.

84 Herbst, 2003. 
According to Otto Kirchheimer there is a traditional distinction between inimicus, the private adversary, and hostis, the foe of the commonwealth. ${ }^{85}$ If this distinction is understood as the distinction between political and common crime, it is clear that terrorists, like pirates, belong to the category of hostis.

Scholars have made a multitude of attempts at defining terrorism. An academically often cited definition is that by Alex P. Schmid:

Terrorism is an anxiety-inspiring method of repeated violent action, employed by (semi-) clandestine individual, group or state actors, for idiosyncratic, criminal or political reasons, whereby - in contrast to assassination - the direct targets of violence are not the main targets. The immediate human victims of violence are generally chosen randomly (targets of opportunity) or selectively (representative or symbolic targets) from a target population, and serve as message generators. Threat- and violencebased communication processes between terrorist (organisation), (imperilled) victims, and main targets are used to manipulate the main target (audience(s)), turning it into a target of terror, a target of demands, or a target of attention, depending on whether intimidation, coercion or propaganda is primarily sought. ${ }^{86}$

Even if Schmid's definition divides terrorism into three categories - idiosyncratic, criminal and political terrorism - most of the academic classifications consider an act of terrorism to be an act committed for a political goal. ${ }^{87}$ Different types of terrorism and terrorists groups are usually categorised according to the ideology behind them. ${ }^{88}$ Other ways of classifying terrorist groups include for instance looking at the tactics and targets they use or their historical roots. ${ }^{89}$ In a chart published in Ross's The Dynamics of Political Crime (2003) that combines different academics' definitions of terrorism, out of four terrorism classics - Proal (1898), Sagarin (1973), Ingraham and Tokoro (1969) and Turk (1982) - only one study, that of Sagarin, does not classify terrorism as political crime. ${ }^{90}$

In a study conducted in 1988, Schmid compared a large number of existing definitions of terrorism. 'Violence' was mentioned in 80 per cent of the studied definitions, 'political' in 65 per cent and 'fear' or 'terror' in 51 per cent. This variance shows how difficult it is to find an accurate and acceptable definition of terrorism, but also that most scholars have typically understood that the political

85 Kirchheimer, 1961, 26.

86 Schmid, 2011, 61, italics added.

87 Some other scholars have also identified non-ideologically motivated terrorism. DeSchutter has called this type of terrorism "terrorisme crapuleux." DeSchutter, 1975, 380.

88 See e.g. the classification in Flemming, Schmid and Stohl, 1988, 155-162.

89 Flemming, Schmid and Stohl, 1988, 165-169.

90 Ross, 2003, 35. 


\section{Concepts employed}

nature of terrorism is one of its defining factors. ${ }^{91}$ What is noteworthy is that only 6 per cent of the 109 studies had used 'criminal' as a definitional element. ${ }^{92}$

The same year, the UN Inter-Regional Meeting of Experts accepted the definition by Professor M. Cherif Bassiouni, a well-known authority in the field of international law. Bassiouni defined international terrorism as "an ideologically motivated strategy of internationally proscribed violence designed to inspire terror within a particular segment of a given society in order to achieve a poweroutcome or to propagandise a claim or grievance, irrespective of whether its perpetrators are acting for and on behalf of themselves, or on behalf of a state." ${ }^{\prime 3}$ Bassiouni also made a distinction between domestic terrorism and common crime with the help of two criteria: "l) the ideological motivation of the actor; and 2 ) the political purpose, or power-outcome, contemplated by the act of violence." 94

Similarly to Bassiouni, Philip Jenkins has also been of the opinion that a terrorist is someone acting on behalf of an ideological motivation. "By most definitions, though, we can only speak of terrorism when a specific political intent is involved, and that means were have to know the person or group responsible." $" 5$ According to Jenkins, terrorists do not aim at only producing destruction or chaos, but in long-term, they aim at becoming a real political force and potentially forming a government. ${ }^{96}$

C.A.J. Coady has also underlined the ideological element in a terrorist act. He has written: "But on my account, terrorism is not 'ordinary' murder since it is a form of murder committed for political purposes by (normally) an organised group. $" 97$ His concept of political includes religious goals that tie to politics. ${ }^{98}$ Coady has drawn the following definition for terrorism: "A political act, ordinarily committed by an organised group, which involves the intentional killing or other severe harming of noncombatants or the threat of the same." 99

It is worth comparing Coady's definition with Colin Wight's, who has written that "Terrorism, [is] the use or threat, of violence by non-state actors against non-state actors to communicate a political message in pursuance of political ends, can be one tactic employed by those protesting against the state." 100 These two definitions are less than ten years old. They differ in important ways, most

91 Schmid, 1988.

92 Jongman, Schmid et al., 1988, 5-6.

93 See Bassiouni, 2001, 16-17. Bassiouni's definition includes also acts of terror committed during international and non-international armed conflicts. Bassiouni, 2001, 18.

94 Bassiouni, 2001, 19.

95 Jenkins, 2003, 6 .

96 Jenkins, 2003, 81 .

97 Coady, 2008, 159.

98 Coady, 2008, 165-166.

99 Coady, 2008, 159.

100 Wight, 2015, 12. It is interesting to note that the first antiterrorism exclusion to the POE, the attentat clause, discussed in the following chapter, would not fall into Wight's classification of terrorism at all. Wight gives a more detailed definition of terrorism later in his book. See Wight, 2015, 120-121. 
centrally in the employment of the concept of non-combatant, which Wight is not willing to use. ${ }^{101}$ The other key difference is Wight's underlining of the role of the state in the definition. However, they are related by the way they understand terrorism as an inherently political phenomenon.

Another well-known scholar to underline the political element in terrorism definitions is Clive Walker. According to Walker: "Putting the public in fear should only be called 'terrorism' if perpetrated with a political motive."102 Also, terrorism expert Bruce Hoffman has emphasised the difference between a criminal and a terrorist act. A criminal act is committed for selfish reasons, whereas a terrorist act aims at creating wider repercussions. ${ }^{103}$ As political criminals by definition, terrorists seek benefit not only for themselves but also for the cause and/ or the community that supports that cause. A terrorist might also be glorified for his or her actions, a treatment common criminals rarely receive. ${ }^{104}$

In her research on political crime, Van den Wijngaert also came to the conclusion that from a sociological perspective, most acts of terrorism can be seen as political crimes. ${ }^{105}$ This is because in most cases, at the time of the writing, they were directed against the state or its subdivision. For this reason, terrorist acts were political offences lato sensu, however serious the acts and whatever their ultimate purpose they are aimed at serving. Simultaneously, Van den Wijngaert underlined the difference between this sociological understanding of terrorism as a political offence and its legal definitions, which have varied across times and between interpreters. ${ }^{106}$

The political element has been acknowledged also by the Global Terrorism database, which has gathered information on most international and domestic terrorist attacks since 1970. The database has applied two different definitions in deciding upon which incidents to include in the material. Both definitions mention ideological goals. The first of these definitions is "the threatened or actual use of illegal force and violence by a non-state actor to attain a political, economic, religious, or social goal through fear, coercion, or intimidation." In the second definition, two of three criteria have to be met: (1) "The violent act was aimed at attaining a political, economic, religious, or social goal." (2) "The violent act included evidence of an intention to coerce, intimidate, or convey some other message to a larger audience (or audiences) other than the immediate victims."

101 "The term non-combatants, on the other hand, is too restrictive and, taken literally, implies that attacks on political leaders, for example, would not be terrorism.” Wight, 2015, 11.

102 Walker, 1992, 9.

103 Hoffman, 1998, 41. A similar idea has been expressed e.g. by Cohen. See Cohen, 2012, 240.

104 Ganor and Conte, 2005.

105 Van den Wijngaert, 1980, 24. She excludes those of psychopathic or common nature from these acts, but I would argue that these acts should not be classified as terrorism to begin with, as their motivations are not political and as this has been seen as an important definitional criteria in defining terrorism. This will be discussed further later.

106 Van den Wijngaert, 1980, 24-25. 


\section{Concepts employed}

(3) "The violent act was outside the precepts of International Humanitarian Law."107

According to the International Institute for Counter-Terrorism (ICT) the most important difference between terrorism and what might be perceived as 'ordinary crime' is that "A terrorist is motivated by a higher cause or ideology that is greater than his or her personal motivations or gains. He or she acts for the furtherance of that external cause (whether it be a localised secessionist movement or global jihad) and the benefit this has to both the cause and the people of it." 108 This definition perfectly fits with the most common understanding of political crime. As discussed earlier, a central element that separates political crime from 'ordinary' crime is the motivation.

In Table 2.1, a number of known legal definitions are compared. Two issues become apparent in this initial analysis. First, there is no general understanding of what elements constitute terrorism. Second, as opposed to academic definitions, legal definitions rarely mention political or ideological motivations to be a part of terrorism definitions due to reasons discussed in this study.

A notable exception is the UK Terrorism Act 2000, under which an act of terrorism is an action which "[...] (b) the use or threat is designed to influence the government or to intimidate the public or a section of the public, and (c) the use or threat is made for the purpose of advancing a political, religious or ideological cause." 109

In 2002, the European Union (EU) adopted a Framework Decision on Combating Terrorism, which, for the first time, succeeded in defining terrorism within the EU. The decision makes a key distinction between common crimes and terrorism based on the intent of the act, and thus acknowledges the political aims behind the acts even without making a direct reference to political motives. This distinguishes it from national law in both 'common law' and 'continental' systems. ${ }^{110}$ The decision lists violent acts which are to be considered terrorist offences if they aim at "(1) seriously intimidating a population, or (2) unduly compelling a Government or international organisation to perform or abstain from performing any act, or (3) seriously destabilising or destroying the fundamental political, constitutional, economic or social structures of a country or international organisation." "11

107 See Data Collection Methodology, http://www.start.umd.edu/gtd/using-gtd/. Retrieved 23 July 2017.

108 Ganor and Conte, 2005. For instance, Saul has pointed out that the emblematic terrorist of our time, Osama bin Laden also had political claims, including: "remove foreign military bases; stop supporting Israel and corrupt Muslim leaders; forbid usury; permit shariah law, and convert to Islam." Saul, 2006, 45.

109 Terrorism Act 2000 c. 11, Part I, Section 1.

110 Casale, 2008.

111 Articlel Council Framework Decision of 13 June 2002 on combating terrorism, 2002/475/JHA, OJ L 164, 22 June 2002. 


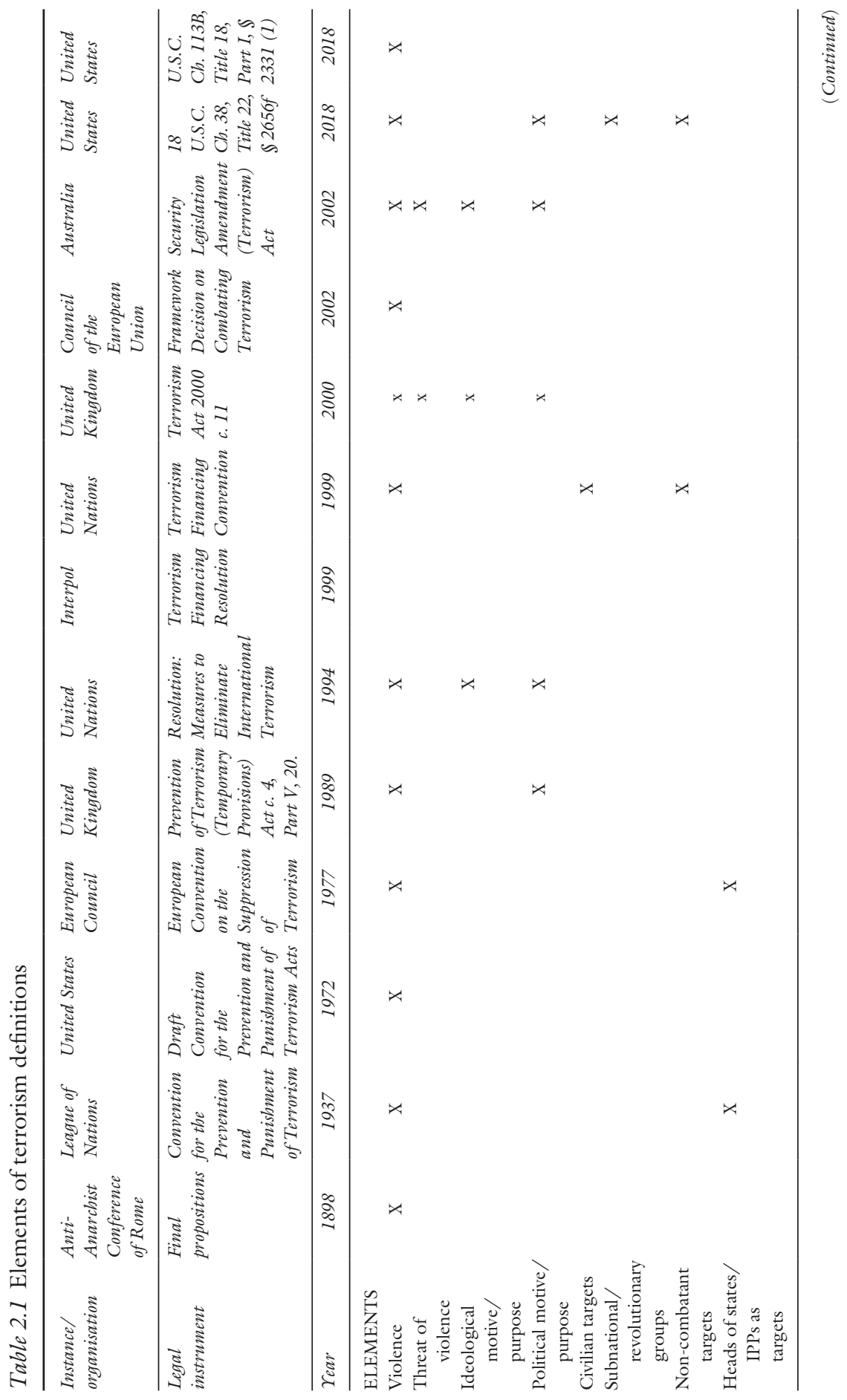




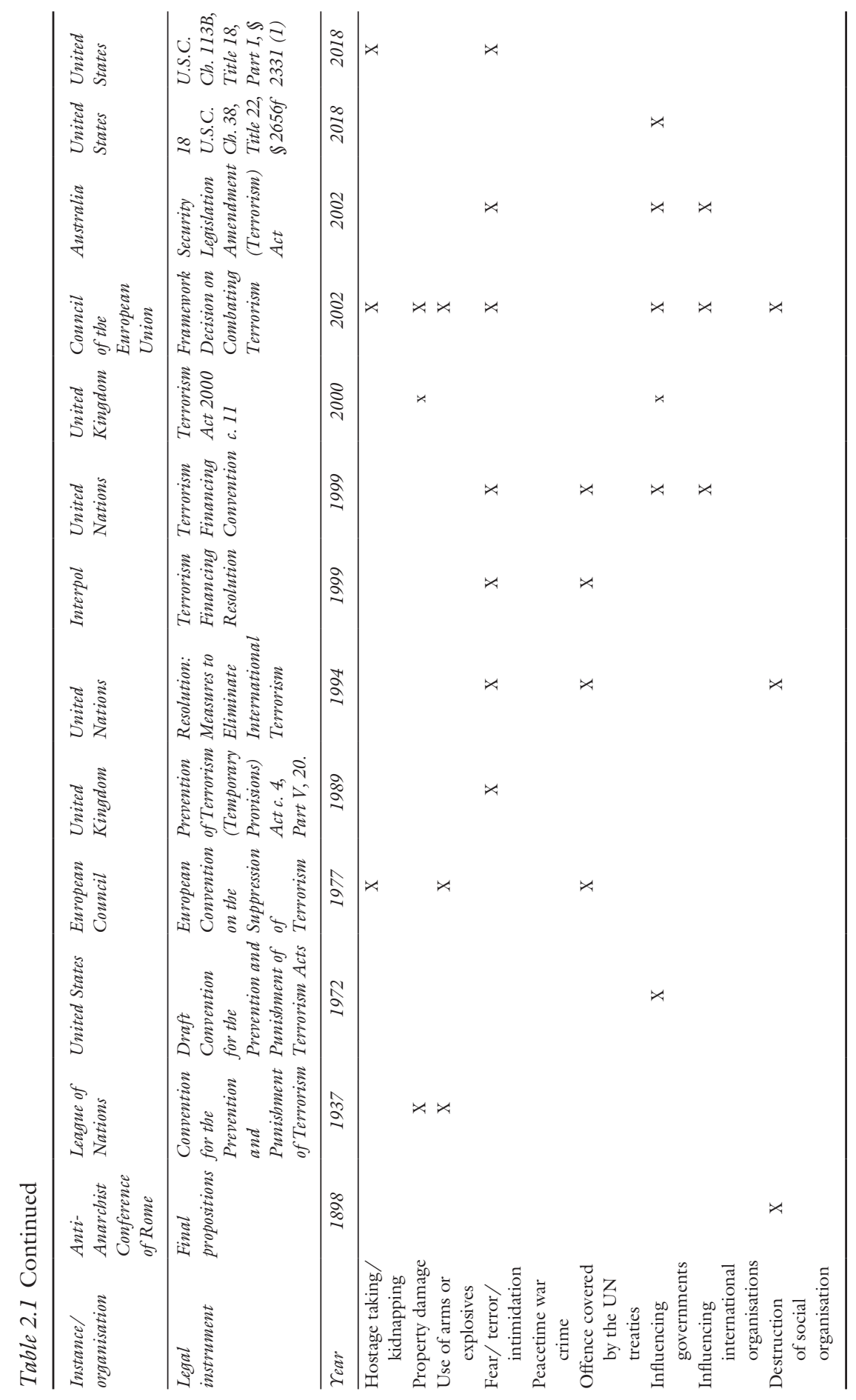


The US federal criminal code defines international terrorism as specific violent criminal activities that occur primarily outside US territorial jurisdiction and that "appear to be intended (i) to intimidate or coerce a civilian population; (ii) to influence the policy of a government by intimidation or coercion; or (iii) to affect the conduct of a government by mass destruction, assassination, or kidnapping." 112 Similar to the EU definition, in this definition the political motive of terrorism has not been openly stated but is referred to in the purposes of terrorist acts. The US federal criminal code also contains another definition of terrorism, for the purposes of the Secretary of State's annual country reports on terrorism in foreign states. According to this definition, 'the term 'terrorism' means premeditated, politically motivated violence perpetrated against noncombatant targets by subnational groups or clandestine agents." ${ }^{113}$ Interestingly, this definition openly accepts the political motivation of terrorism.

Even if not all legal definitions incorporate the concept of the political as a component, it is possible to claim from an analytical point of view that terrorism can be distinguished from common crimes on the basis of its ideological motivation. As discussed, the incentive for 'ordinary crimes' is usually the search for personal gain. What would terrorist acts be without the political/ideological element? They would be called mass killings, hijackings, bombings... Common criminality, often with uncommonly destructive elements. ${ }^{114}$

Can it then be said that terrorism is political criminality if the political/ideological element is always present in the acts? This has been a topic of discussion for decades, and there is no conclusive answer to the question. However, based on the fact that there is always a criminal element to terrorism, and there seems to be a general understanding of terrorism as a means to achieve political goals, realistic or not, it can be claimed that terrorism fits into the category of political crime. This is confirmed by the classifications of authoritative researchers.

However, while the notion 'political crime' seems to be fitting to describe terrorism, it is clear that based on the aforementioned classifications, terrorism is not a 'pure' political crime. It would fall under the concept of 'mixed' or 'relative' political crimes. This makes the question of terrorism as a political crime more complex, as there is no shared understanding of which relative political crimes, if any, count as political crimes.

Some have pointed out that there are similarities between acts of terrorism and 'pure' political crimes. The label terrorism can be used to delegitimise and criminalise opposition to the rule of the state. The same has been true of pure political crimes such as 'sedition,' 'treason' and 'subversion.' It has been claimed that 'terrorism' as a concept is used in a similar manner as these terms before it.

112 U.S.C. Ch. 113B, Title 18, Part I, \$2331 (1).

11318 U.S.C. Ch. 38 , Title 22 , Annual country reports on terrorism, $\$ 2656 f 3(d)$.

114 For instance the Canadian government has made the point that removing the motive element would make terrorism offences indistinguishable from ordinary crimes. See Saul, 2008,3 . 
These terms are used to label differing political views and action in a way that opens them up for state repression. ${ }^{115}$ However, placing terrorism into the same category as these pure political crimes is not justifiable due to its violent element.

Terrorism is often treated as an ideology itself, possibly because the concept seems to link it with other 'isms,' concepts that typically describe ideologies and belief systems. However, according to C.A.J. Coady, in the concept of terrorism, the 'ism' points to the systematic nature of the method or tactic. ${ }^{116}$ Terrorism is not an ideology but is used to serve an ideological purpose. In other words, it is not an end, but a means to an end, as different forms of violence typically are. ${ }^{117}$ Terrorism can never be completely eliminated as it can serve any given ideology. ${ }^{118}$

When terrorism is understood as a means to achieve an end rather than as an end itself, it becomes clear that a division between so-called freedom fighters and terrorists cannot be made. Terrorists use terroristic violence in trying to achieve a political goal. As pointed out by Wight, the nature of the goal does not change the nature of the act. Hence, the goal might, for instance, be labelled as freedom. ${ }^{19}$ As freedom is a term that does not come with a clear-cut definition, it is clear that terrorists might understand their acts as serving the purpose of promoting freedom. For this reason, I find the separation made between 'freedom fighters' and 'terrorists' analytically useless.

An extensive description of terrorism is given by the Memorial Institute for the Prevention of Terrorism (MIPT):

Terrorism is violence, or the threat of violence, calculated to create an atmosphere of fear and alarm. These acts are designed to coerce others into actions they would not otherwise undertake, or refrain from actions they desired to take. All terrorist acts are crimes. Many would also be a violation of the rules of war if a state of war existed. This violence or threat of violence is generally directed against civilian targets. The motives of all terrorists are political, and terrorist actions are generally carried out in a way that will achieve maximum publicity. Unlike other criminal acts, terrorists often claim credit for their acts. Finally, terrorist acts are intended to produce effects beyond

115 Grace and Leys, 1989, 66.

116 Coady, 2008, 155.

117 Coady, 2008, 157. See also Jenkins, 2003, 4. A similar point has been made by Wight, $2015,8,12$. Charles Tilly has made an interesting note between the concepts of force and violence: "Rulers, police, philosophers, and historians often distinguish between force and violence. Force, in this view, consists of legitimate short-run damage and seizure - which typically means that the persons who administer damage enjoy legal protection for their action. Force might therefore include legitimate self-defence but not unprovoked aggression. In such a perspective, violence refers to damage that does not enjoy legal protection.” According to Tilly, the boundary between the two is not necessarily useful or clear. Tilly, 2003, 27.

118 Jenkins, 2003, 4.

119 Wight, 2015, 110. 
the immediate physical damage of the cause, having long-term psychological repercussions on a particular target audience. The fear created by terrorists may be intended to cause people to exaggerate the strengths of the terrorist and the importance of the cause, to provoke governmental overreaction, to discourage dissent, or simply to intimidate and thereby enforce compliance with their demands. ${ }^{120}$

This description makes two strong statements, one of which is accepted by many ("all terrorist acts are crimes") and the second of which has been questioned by some ("the motives of all terrorists are political"). Whether this premise is true depends on which definition of terrorism one accepts. If such a claim is accepted, it can have major implications for instance on the status of the criminal in the eyes of the public (political wrongdoers can even be regarded as selfless saints), and from a legal viewpoint. One important and very practical consequence of a crime being labelled political is the protection the offender can get from extradition procedures. Traditionally, political criminals are protected from extradition by treaty provisions. Understanding terrorism as political criminality could have a major effect on how terrorists are treated, as long as terrorism is not internationally excluded from the protection of the POE.

In my view, terrorism should be excluded from the protection of the POE and it should be viewed as political crime. I understand terrorism as violent criminal action aimed at persons used as symbolic targets with the objective of generating extreme fear in the general population, for the purposes of advancing political or ideological goals. ${ }^{121}$ My definition includes acts committed during wartime, as even during the course of war, using persons (civilians or soldiers) as symbolic rather than strategic targets should not be acceptable. This way it evades the definition of a specifically civilian target. Acknowledging the political roots of terrorism should serve the purpose of analytically separating it from other types of serious crime, which in turn should assist in combatting it in the most appropriate manner.

\subsubsection{Terrorism as uncivil disobedience}

Not all students of terrorism would place it into the category of political crime. According to Schmid, it is problematic to call terrorism political violence. First, this implies that also non-political terrorism would exist. Second, he sees that the

120 Terrorism Knowledge Base/MIPT, http://www.tkb.org/RandSummary.jpp?page=about. Retrieved 12 December 2007.

121 Compare with Cassese, 2006, 937, who has argued that the generally agreed definitional elements of terrorism are that the acts are nationally criminalised, they are intended to provoke a state of terror or coerce a state or international organisation and they are politically or ideologically motivated. See for further discussion on the definition Dugard, 1973; Schmid, 1984, 1992, 2011; Herbst, 2003; Saul, 2005; Fletcher, 2006; Young, 2006; Blakesley, 2007; Bryan, 2012; Wilkinson, 2012; Angli, 2013; and Di Filippo, 2014, amongst many others. 
concept of political violence typically relates to collective movements, whereas terrorism is the work of a marginal segment in society. Third, political violence is typically used to describe a domestic phenomenon, whereas the nature of terrorism is international. Finally, describing terrorism with a term as vague and general as 'political violence' does not seem useful. ${ }^{122}$

I agree with Schmid's idea about terrorism always being a political phenomenon. Non-political terrorism should be described with other concepts. However, I disagree with the idea that terrorism is a marginal phenomenon. True, the number of terrorists is minimal but they can still be motivated by political views shared by a wider group. Additionally, I do not see that there is a need to distinguish between domestic and international terrorism on the definitional level.

Some scholars accept acts committed for other than political motives in their classifications of terrorism. Their categorisations of terrorism would thus include for instance certain types of serious violent acts committed by psychopaths or organised crime groups. There are varying classifications that include other types of terrorism than political terrorism. For instance, the Report of the Task Force on Disorders and Terrorism in 1976 identified five different types of terrorism: political terrorism, non-political terrorism, quasi-terrorism, limited political terrorism, and official or state terrorism. ${ }^{123}$

Out of these, political terrorism was characterised as "violent criminal behaviour designed primarily to generate fear in the community for political purposes." Non-political terrorism, in turn, is committed for private purposes, whereas quasi-terrorism describes "those activities incidental to the commission of crimes of violence that are similar in form and method to true terrorism but which nevertheless lack its essential ingredient." The essential ingredient referred to is the ideological motivation behind the actions. Limited political terrorism in this classification was understood as "acts of terrorism which are committed for ideological or political motives, but which are not part of a concerted campaign to capture control of the state." For instance, lone-wolf types of actions could fall into this category. This categorisation also included official or state terrorism. State behaviour would be considered terrorism in states where the ruling "is based upon fear and oppression that reach terroristic proportions." 124

Other classifications have also been separated between different types of terrorism based on their motivations. Paul Wilkinson (1976) divided terrorism into criminal, psychotic, war, and political, which can be either revolutionary, subrevolutionary, or repressive. Frederick Hacker (1978) saw terrorists representing three groups: 'crusaders,' 'criminals' and 'crazies.' Also, Alex Schmid and Janny de Graaf (1982) classified terrorism into three groups: (1) insurgent terrorism, (2) state or repressive, and (3) vigilante. In this classification, insurgent terrorism

122 Schmid, 1984, 22.

123 National Advisory Committee, 1976, pp. 3-6, cited in Hagan, 1997, 134.

124 Hagan, 1997, 134. 
can further be divided into three subgroups: (a) social revolutionary; (b) separatist, nationalist or ethnical; and (c) single issue. ${ }^{125}$

In more recent academic publications, terrorism is growingly linked with the phenomenon of organised crime as opposed to political crime. Many 'handbooks' and other compilation books discuss these under the same chapter. ${ }^{126}$ This trend follows the lines of the United Nations and police organisations, which are also growingly treating terrorism as a part of a wider problem of organised criminality. ${ }^{127}$ As terrorist acts require assets, and these assets are often at least partly obtained by illegitimately moving money, people and/or chemicals/weaponry across national borders, some have claimed that terrorism is best described as a form of organised crime. ${ }^{128}$ Furthermore, in some cases, former political terrorists have become more and more like common criminals. For instance, in Northern Ireland, some of the former paramilitaries often seen as terrorists have turned towards committing crimes for the purpose of personal gain. ${ }^{129}$

It is interesting that several academic writers include acts committed for purely personal motives in their groupings of terrorism and use a specific term usually implying the presence of a political motive to describe an act committed for nonideological reasons. In these cases, it seems that the term 'terrorism' is merely used to underline the seriousness of the crimes. The use of the term for such a purpose does not serve the aim of trying to create an international definition of terrorism. Interestingly, Murphy, writing in 1985, noted that for some governments, acts of terrorism were exactly those committed for personal motives, and acts committed for a political cause, such as against colonialism or for the cause of national liberation, fell out of the scope of the term, constituting legitimate measures of self-defence. It was thus the rightness of the cause that made the difference. ${ }^{130}$

In addition to the categorisation of terrorism as a common or political crime, another division lies in whether it is seen as a crime at all. It is conceivable to judge a terrorist act as an act of warfare as opposed to a criminal act. If terrorism is considered as a crime, it is necessary to treat it like one: to gather evidence, arrest the perpetrators and put them on trial. This kind of approach may pose problems for international cooperation and is not applicable in cases where the terrorist act is executed by a 'distant organisation' or a country. To consider terrorism as warfare the importance of individual guilt is less relevant and the focus is on the proper identification of the enemy. In contrast, by treating terrorism as

125 Hagan, 1997, 135. See for a discussion on different typologies of terrorism, Wight, 2015, 173-178.

126 Maguire, Morgan and Reiner, 2007.

127 This will be discussed in more detail later.

128 Levi, 2007, 774-775.

129 Levi, 2007, 791.

130 Murphy, 1985, 4. 


\section{Concepts employed}

an 'ordinary' crime, the possibility of treating criminals differently for political reasons is or should be prevented. ${ }^{131}$

Both the 'warfare' and 'criminal' approaches have been used as a basis for anti-terrorist actions. For instance, the ongoing work of Interpol represents the 'criminal' approach and the unfinished wars in Iraq and Afghanistan the 'warfare' approach.

This book concentrates purely on anti-state political terrorism. As most scholars perceive that the political motivation is a constituting factor of terrorism, it is possible to argue that acts without political motives cannot be considered terrorist but serious organised crime. ${ }^{132}$ Thus the concept of terrorism can be understood to exclude 'ordinary' criminal motives or deeds committed by people with mental problems. ${ }^{133}$

Terrorist acts (try to) serve a purpose: they do not usually aim at producing random chaos in society, but at challenging the authority of the ruling government, accelerating social disintegration, or demonstrating the inabilities of the current regime to govern. ${ }^{134}$ Terrorists seek fundamental change in a society, ${ }^{135}$ and use violence as a means of political action. ${ }^{136}$ It is clear that the use of terrorist tactics, indiscriminate violence against the civilian population, is condemnable, but tactics labelled terrorism have also been used to rebel against tyranny and oppression. ${ }^{137}$ Additionally, if assassinations of heads of states are considered terroristic, the criteria of indiscriminate acts are no longer valid.

Many writers before me have seen terrorism as a form of political violence. ${ }^{138}$ I understand political violence in the same way as Wight does, as the use of force for political ends. ${ }^{139}$ Charles Tilly claimed that all forms of collective violence are forms of contentious politics: "[Collective violence] counts as contentious because participants are making claims that affect each other's interests. It counts as politics because relations of participants to governments are always at stake." 140

Some writers have called political terrorism a 'political tactic,' 'political behaviour,' or a 'political shortcut.' 141 There are bases for using such labels. Terrorism is a tactic, chosen out of a selection of different tactics. It is often used when the

131 Ganor and Conte, 2005.

132 Cancio Melia and Petzsche, 2013, 103-104. Such an act could also fall under a national definition of terrorism, as noted by Cassese. Cassese, 2006, 940 .

133 Ross, 2003, 63.

134 Stohl, 1988, 16.

135 Stohl, 1988, 5; Targ, 1988, 130.

136 Cancio Melia and Petzsche, 2013, 103.

137 See e.g. Bassiouni, 1975, xii.

138 Wight, 2015, 2.

139 In this definition, violence is understood as "behaviour involving physical force intended to hurt, damage or kill someone or damage something." Wight, 2015, 106.

140 Tilly, 2003, 26.

141 Corrado and Evans, 1988, 374; Stohl, 1988, 11; Targ, 1988, 130; Wright and Miller, 2005, 1225-1230; Cancio Melia and Petzsche, 2013, 103. 
political goals sought lack democratic support, and when legitimate means seem inefficient in pursuing these goals. ${ }^{142}$

Most of all, terrorism is a means to transmit a message, ${ }^{143}$ a form of political communication, aimed at criticising current political structures. ${ }^{144}$ Common crimes do not aim at disseminating an agenda. The combination of sending a message with seeking change in the society has inspired some to call terrorism 'diplomacy of violence' or 'coercive diplomacy.' 145

In the era of mass media, terrorism in democratic societies is a cry out that is unlikely to go unheard. It is possible that terrorism gets its message through to a larger audience. According to Ted Robert Gurr, "Terrorism is a cheap and easy way of doing so, and one that carries relatively little risk." ${ }^{146}$ However, the strategy can be counterproductive in democratic nations. Only in a handful of cases, terrorism has had a political effect. ${ }^{147}$ It has been claimed that the so-called Munich Massacre committed by the Palestinian group Black September in 1972 made the Palestinian cause known to the wider public. ${ }^{148}$ Even if the goal has not been reached, terrorism has undeniably had an effect on the politics in the Middle East. ${ }^{149}$

The objectives of terrorists vary. Some have 'non-negotiable demands,' such as the total destruction of a specific society or way of life, impossible to satisfy by political agents. These types of terrorists are usually treated as security problems. Others with more achievable goals can use terrorism as a bargaining tactic. ${ }^{150}$ Gurr has compared this kind of terrorism to labour protests. Strikes were also treated as security problems before they grew in proportion and the accommodation of workers' demands became necessary. ${ }^{151}$ At the same time, Gurr's research (1988) showed that in four-fifths of terrorist cases, the objectives could be inferred from the nature of the action. ${ }^{152}$ Thus the purpose of terrorism is a means to communicate a message. Its efficiency of doing so and, naturally, its legitimacy can be questioned.

All of the aforementioned features - aiming for social change, trying to communicate a message, using terrorism as a strategy to achieve political goals - point to the strong link between terrorism and politics. I understand terrorism as a part of a continuum of political action, where at one extreme lies sanctioned political

142 Gurr, $1988,51$.

143 See e.g. Stohl, 1988, 3, 5; Hoffman, 1998, 42; Wight, 2015, 2.

144 Wight, 2015, 3. See in detail on the relationship between terrorism and the state, Wight, 2015.

145 Stohl, 1988, 5.

146 Gurr, 1988, 52 .

147 Gurr, 1988, 48 .

148 See e.g. Chapter 4, Section 4.1.2.

149 Stohl, 1988, 20-23.

150 Gurr, 1988, 53; Flemming, Schmid and Stohl, 1988, 155.

151 It has to be noted, though, that Gurr's text dates from the late 1980s, a time which hadn't yet seen the massive devastation terrorism would cause in the coming decades. Gurr, 1988, 53.

152 Gurr, 1988, 46. 


\section{Concepts employed}

participation (such as voting), in the middle accepted measures of opposition such as protests and civil disobedience, and at the other extreme illegitimate measures and finally terrorism.

As political action, terrorism could be called 'uncivil disobedience,' a concept used by Christian Bay. He has first defined 'civil disobedience' to include "any act or process of public defiance of a law or policy enforced by established governmental authorities, insofar as the action is premeditated, understood by the actor(s) to be illegal or of contested legality, carried out and persisted in for limited public ends $[\ldots]$ by way of carefully chosen and limited means that exclude measures that could cause personal injuries or even the loss of life." Uncivil disobedience, in turn, does not recognise the limits mentioned in this description. ${ }^{153}$ Similarly, Colin Wight has placed terrorism at the extreme end of a continuum of political protest. ${ }^{154}$

As the preceding discussion has shown, there is a clear link between politics and terrorism, no matter how indefensible the acts. The political nature of terrorism is what separates it from other types of violent crime.

\subsubsection{Terrorism as an international crime}

It seems evident to think about terrorism as an international crime. However, international law has had difficulties with dealing with the phenomenon because the body of international law is state centred and has had trouble with fitting international organisations or individuals in the picture. ${ }^{155}$ Further, even the usefulness of labelling terrorism as an international crime can be debated. If such a label is used, terrorism is no longer left to domestic legal systems to prosecute, ${ }^{156}$ but it falls within the international domain which offers, in fact, more protection to the accused than domestic laws do. ${ }^{157}$

A vivid debate on whether terrorism should be considered an international crime is ongoing in the field of international criminal law. ${ }^{158}$ Partly this debate was already solved in 1949 when crimes of terrorism during international armed conflicts were incorporated into the Geneva Conventions. The conventions prohibit the use of "measures of terrorism" and "acts of terrorism." The Fourth Convention forbids "collective penalties and likewise all measures of intimidation or of terrorism" and the 1977 Additional Protocol II prohibits "acts of terrorism" against persons not or no longer taking part in hostilities during

153 Bay, 1989, 42.

154 Wight, 2015, 11.

155 Klabbers, 2004, 300.

156 Because no international tribunal has the competence to prosecute terrorist acts, only states are able to enforce anti-terrorist laws and prosecute those acts that are nationally criminalised. Sambei, Du Plessis and Polaine, 2009, 30.

157 Klabbers, 2004, 301.

158 See e.g. Journal of International Criminal Justice, 2006, issue 5; Cassese, 2006; Saul, 2006; Ambos and Timmerman, 2014. 
non-international armed conflicts. The main aim is to emphasise that neither individuals nor the civilian population may be subject to collective punishments, which, among other things, obviously induce a state of terror. ${ }^{159}$

Once the 'war on terror' was proclaimed after the terrorist attacks in the United States in 2001, the question arose whether terrorist attacks could amount to an armed conflict regulated by International Humanitarian Law (IHL). ${ }^{160}$ It seems that IHL might be able to accommodate terrorist acts but no general consensus over this exists. ${ }^{161} \mathrm{IHL}$ specifically rules out isolated, sporadic and low-level acts of violence. However, in some cases the conflict between a state and an organised group can be intense enough to amount to a non-international armed conflict. ${ }^{162}$ The status of terrorist crimes during peacetime has been more unclear and much debated. Typically, terrorism is not a matter that is brought to an international court but dealt with in domestic courts instead. ${ }^{163}$

International criminal law can be divided into treaty-based crimes and 'true' core international/supranational crimes. Specific acts of terrorism are also defined by UN antiterrorism conventions and are, as such, international treaty crimes. By their very nature, they can become part of the signatory states' legal systems either automatically (monist systems) or through implementation in the legislation (dualist systems). ${ }^{164}$ Certain acts of terrorism are treaty-based international crimes, as discussed further in Chapters 4 and 5 . Treaty-based crimes need to be implemented and prosecuted nationally, which limits their coverage. True international crimes create individual international criminal responsibility and they can be prosecuted in an international court. A treaty-based crime can develop into a true international crime through customary law. ${ }^{165}$

However, there is no general understanding of whether terrorism can also be considered a core international crime. The emergence of an international definition could possibly qualify it as such. ${ }^{166}$ For instance, when the International Criminal Court (ICC) was being created, some states suggested that a new crime

159 Article 33, Convention (IV) relative to the Protection of Civilian Persons in Time of War, 12 August 1949. Article 4 (2) (d) Protocol Additional to the Geneva Conventions of 12 August 1949, and relating to the Protection of Victims of Non-International Armed Conflicts (Protocol II), 8 June 1977.

160 Saul, 2014b, 209.

161 See Saul, 2014b, and Arnold, 2014, or a longer discussion on the relationship of IHL and terrorism. According to Cassese, for example, the creation of the International Criminal Tribunal for Rwanda and the Special Court for Sierra Leone with jurisdiction over terrorist crimes together with UN instruments condemning terrorism would seem to suggest that terrorism can be understood as a war crime. See in more detail Cassese, 2006, 945-946.

162 Saul, 2014b, 212.

163 Nuotio, 2006, 1000.

164 There is variation in monist systems for example concerning where the treaties fall in the hierarchy of laws and in whether their provisions are directly applicable in the criminal proceedings. Sambei, Du Plessis and Polaine, 2009, 9-12. The UN treaties covering specific crimes of terrorism are covered in Chapters 4 and 5 .

165 Ambos and Timmerman, 2014, 23-25.

166 Nuotio, 2006, 1003. 
of terrorism should be under its jurisdiction. This proposition faced opposition, for instance from the United States. One of the key reasons for the opposition was the lack of an international definition of terrorism. In addition, there was fear that the court would be politicised and that nations would not wish to join. Some were worried about the workload of the ICC, while others claimed that terrorism was not a serious enough crime to be considered in the court. Additionally, many of the developing countries wanted a distinction made between terrorism and the struggle for self-determination or independence. ${ }^{167}$ Some have argued that even if terrorism is not a core international crime, it can amount to one in case the attack fulfils specific requirements such being "widespread and systematic" and targeting the civilian population. ${ }^{168}$

In 2012, the Special Tribunal for Lebanon (STL) identified a definition of international terrorism under customary international law. The elements of the definition include the use or threat of use of violence, the indiscriminate nature of the act, its targeting of civilians, and its aim to coerce a government or an international organisation. ${ }^{169}$ According to Saul, the legal consequences of the definition have been rather theoretical than practical. ${ }^{170}$

\subsubsection{The de- and repoliticisation of terrorism}

The process of extradition is one of the key non-violent means to fight terrorism, but it has not gained as much publicity as other, more drastic measures. ${ }^{171}$ Especially prior to the current era, where a war on terrorism ${ }^{172}$ has openly been waged, non-violent means were the most important mechanisms in combatting terrorism. Up until the 2000s, military means were rarely used in the fight against terrorism.

Extradition is not a preventative measure, as it is only used after a crime has occurred. However, the importance of extradition treaties should not be underestimated. They reduce the number of safe havens for terrorists and prevent them from escaping justice. The aut dedere aut judicare principle used in many international antiterrorism conventions obliges states to either extradite persons found

167 Cassese, 2001, 994; Cohen, 2012, 223-229. See for a discussion on the possible inclusion of the crime of terrorism within the jurisdiction of the ICC, Cohen, 2012, and Arnold, 2014.

168 Nuotio, 2006, 1000. In such a case it could represent a crime against humanity. See in more detail Cassese, 2006, 948; and Cohen, 2012, 242-246. For instance, the terrorist attacks against the US in 2001 have sometimes been interpreted as crimes against humanity. See Cassese, 2001, 994-995.

169 STL Interlocutory Decision on the Applicable Law: Terrorism, Conspiracy, Homicide, Perpetration, Cumulative Charging, Case No. STL-11-01/I, 89, Feb. 16, 2011. See also Cohen, 2012, 230-231. See e.g. Ambos and Timmerman, 2014, 28-30, for a commentary on the statement by the STL; and Mettraux, 2014, for a more detailed analysis.

170 Saul, 2015, 406.

171 Petersen, 1992, 771.

172 See in more detail e.g. Blakesley, 2007, 295-307. 
in their territory who are wanted for trial for an extraditable offence by another party or to try the fugitives themselves. ${ }^{173}$

The extradition of terrorists has, however, not always been successful. One reason for the lack of success has been the political offence exception to extradition. To prevent terrorists from escaping justice, terrorist acts have growingly been depoliticised so that they can be excluded from the scope of protection. Depoliticisation is one of the key concepts used as a tool of analysis in this study. In the following, I will define the term for the purposes of this study. ${ }^{174}$ What makes this task challenging is the "extreme ambiguity of the concept." 175 This section elucidates the interpretation of the concept in the framework of this book.

The concept of depoliticisation can be used for various purposes. It can be understood as an official act performed by a government, as something brought about by the media (e.g. depoliticising a conflict) or by actors a specific government or international organisation on a certain issue, or it can be understood as a process in the society.

For instance, at the beginning of the 1960s, there were fears and assumptions of the depoliticisation of society in some Western European countries. Depoliticisation was used to describe a passive phenomenon, as opposed to depoliticising, and it was understood as a threat. ${ }^{176}$ Contemporaries characterised the phenomenon as the "erosion of ideology."177

The Merriam-Webster dictionary now defines depoliticisation and depoliticising equally and in a straightforward manner: "to remove the political character of: take out of the realm of politics." According to David Held, something is depoliticised when it is "arbitrarily treated as if it were not a proper subject of politics." 178 In general, something depoliticised is interpreted as politically neutral. ${ }^{179}$

Depoliticisation can be perceived as the opposite of politicisation. Kari Palonen clarifies the meaning of politicisation by comparing it with politicking. "In Weberian terms, I consider politicking as the search for new power shares within an existing polity, while politicisation concerns the redistribution of such shares in a polity-complex in a manner that opens new Spielräume for politicking." 180 Depoliticisation thus removes an issue from the sweep of political.

The concept of depoliticisation is used in this study in a manner that partly differs from its traditional use. It is used to describe the outcome of the act of depoliticising. Instead of a passive phenomenon, I understand depoliticisation as a deliberative act. Examples of the use of the strategy of depoliticising can be

173 Oppenheim, Jennings and Watts, 1992, 953. See also Plachta, 1999, 123-140.

174 See the special issue on depoliticisation in Policy and Politics, volume 42, number 2, April 2014 , for a detailed discussion on the concept and its current meanings.

175 “l'extrême ambiguïté du concept” Vedel, 1962, 5.

176 Himmelstrand, 1961; Vedel, 1962, 8, 11.

177 Himmelstrand, 1961, 2.

178 Held, 174, 1995.

179 Turner, 1989, 550.

180 Palonen, 2003. 
Table 2.2 Methods of depoliticisation

\begin{tabular}{|c|c|}
\hline Method of depoliticisation & Employed by (examples) \\
\hline $\begin{array}{l}\text { Transfer of political } \\
\text { powers to 'non- } \\
\text { political' actors }\end{array}$ & Application of the POE in the hands of the courts (USA) \\
\hline $\begin{array}{l}\text { Ends do not justify the } \\
\text { means }\end{array}$ & $\begin{array}{l}\text { Council of Europe Recommendation on International } \\
\text { Terrorism } 684 \text { (1972) and } 703 \text { (1973); UN } \\
\text { Declaration on Measures to Eliminate International } \\
\text { Terrorism (1994); Interpol Resolution on the } \\
\text { Financing of Terrorism (1999) }\end{array}$ \\
\hline Exclusion from the POE & $\begin{array}{l}\text { ECST (1977); US-UK Supplementary Treaty (1985); } \\
\text { UN Terrorist Bombing Convention (1998); UN } \\
\text { Terrorism Financing Convention (1999) }\end{array}$ \\
\hline $\begin{array}{l}\text { Claim that terrorism has } \\
\text { nothing to do with } \\
\text { politics }\end{array}$ & Anti-Anarchist Conference of Rome (1898) \\
\hline $\begin{array}{l}\text { No mention of political } \\
\text { motivation }\end{array}$ & $\begin{array}{l}\text { League of Nations Terrorism Convention* (1937); } \\
\text { UN Terrorist Bombing Convention (1998); UN } \\
\text { Terrorism Financing Convention (1999); UN Draft } \\
\text { Convention on Terrorism }(2000)\end{array}$ \\
\hline $\begin{array}{l}\text { Dealing with specific } \\
\text { elements }\end{array}$ & $\begin{array}{l}\text { UN antiterrorism conventions, e.g. the Montreal } \\
\text { Convention (1970); the Hostages Convention } \\
\text { (1979) }\end{array}$ \\
\hline
\end{tabular}

* Convention for the Prevention and Punishment of Terrorism.

found in history. It has been stated that modern liberalism was founded on the depoliticisation of religion as a result of the wars on religion. ${ }^{181}$

The depoliticisation of terrorism can take many different forms, as presented in Table 2.2. I have separated six different forms of depoliticisation for analytical purposes. All these six forms have been visible in the policies, treaties, conventions and laws analysed in this study.

First, depoliticisation can be understood as the transfer of functions commonly thought of as political to organs that are (at least to some extent) remote from political control. Buller and Flinders argue that depoliticisation should be referred to as 'arena-shifting':

decisions are made no less political by delegating them to an 'independent' body or making them according to a rule-based framework. In reality, politics is transferred to a new arena. [...] While politicians may seek to insulate certain issues from the political domain, it is unlikely that the wider public

181 Turner, 1989, 555. 
of that polity will accept that a certain issue is no longer 'political'. It is clear from past experience that if an issue becomes politically salient in the eyes of the public it will make little difference to the public whether the policy is the responsibility of a state-owned company, an independent regulator or a quasi-autonomous agency. ${ }^{182}$

Depoliticisation can thus protect the government from the consequences of unpopular policies. One example of such depoliticisation is the tradition in the US of giving decision-making powers over extradition procedures to the courts instead of the executive.

Second, it is possible to depoliticise terrorism by claiming that whatever the ends of the offenders, they are not justified by the use of terroristic means. This formulation does not depoliticise the acts themselves, as it acknowledges their motivations. However, it depoliticises their treatment.

Third, excluding terrorists from the scope of the protection of the political offence exception can be seen as a form of depoliticisation. This is one of the core themes of this study. This solution is related to the previous one, as it does not necessitate the denial of the political nature of the acts, but merely excludes them from being treated similarly to other political crimes.

The fourth, most overt way to depoliticise terrorism is to openly claim it has nothing to do with politics. This open formulation has only been used by the Anti-Anarchist Conference of Rome 1898. ${ }^{183}$

Fifth, it is possible to understand that referring to terrorism as something non-political is also a strategy of depoliticisation. This is because as established, terrorism is, by (academic) definition, an inherently political phenomenon.

Finally, one of the most commonly used tactics to depoliticise terrorism is to criminalise, with no mention of their motivations, specific acts typically used by terrorists, be they done for political or other reasons. This way terrorism can be treated as common criminality. This is linked with the fifth method, not mentioning the political objectives at all.

Following Mathieu Deflem's ideas, the last strategy implies that terrorist acts are stripped of their political contexts and aims and their criminal nature is emphasised. More concretely, terrorist acts are broken down into their constituent parts, so that their criminal elements can be identified and subjected to police investigations. ${ }^{184}$ Deflem sees that the depoliticisation or criminalisation of terrorism "is accomplished by defining terrorism very vaguely ('a crime against humanity') and/or by identifying and isolating the distinctly criminal elements (bombings, killings) from terrorist incidents." Understanding terrorism separate from its ideological motivations enables one to consider it criminal. This way

182 Buller and Flinders, 2005.

183 See in more detail Chapter 3, Section 3.2.

184 Deflem, 2006. 
terrorism can be separated from politics. The same logic was followed first in extradition treaties and later also in UN antiterrorist treaties. ${ }^{185}$

Repoliticising, a term also used in this study, is the opposite: it underlines the political nature of terrorist acts. Punishing certain political acts that are not in themselves criminal due to their relationship with terrorist acts can also be understood as repoliticisation. Such acts can include for instance spreading terrorist propaganda. It is argued in this book that the purpose of the repoliticisation of terrorism has, perhaps surprisingly, been the same as the depoliticisation. Repoliticisation serves the purpose of more severely condemning terrorist actions, of criminalising auxiliary acts and of bringing terrorists to military courts. Chapter 5 , Section 5.3 discusses the repoliticisation of terrorism which has occurred simultaneously with the trend of depoliticising terrorism.

\subsection{Extradition: legal and diplomatic function}

\subsubsection{Reciprocal legal assistance}

Extradition is one of the key concepts of this study. It is suggested that one of the reasons why terrorism has been depoliticised globally is the so-called political offence exception to extradition (POE), which has traditionally been included in almost all extradition treaties. The aim of this part is to give an overview of the topic of extradition.

Extradition is a form of mutual legal assistance between two states, and as such it lies at the intersection of national and international law. ${ }^{186}$ In extradition proceedings, one state requests the surrender of a fugitive for prosecution or for the purpose of executing a sentence. National sovereignty requires that each state has jurisdiction over persons in its own territory. The state has no duty to admit or to exclude aliens to or from its territory, and thus no duty to extradite upon request unless a treaty is in place. ${ }^{187}$ In other words, international law does not require extradition. ${ }^{188}$ Extradition is regulated either through bilateral treaties, regional multilateral treaties, mutual recognition schemes such as the European Arrest Warrant (EAW), UN Conventions, ad hoc arrangements or through comity, which means the willingness to extradite when no treaty is in place. ${ }^{189}$ Bilateral

185 E.g. "In terms of the objectives of social control, the bureaucratisation of policing involves most noticeably a de-politicisation of the target of counter-terrorism. This criminalisation of terrorism is accomplished by defining terrorism very vaguely ('a crime against humanity') and/or by identifying and isolating the distinctly criminal elements (bombings, killings) from terrorist incidents." Deflem, 2006.

186 Blakesley, 2007, 257-258.

187 See e.g. Sambei, Du Plessis and Polaine, 2009, 405; or Oppenheim, Jennings and Watts, 1992, 948-971, on the rules of international law concerning extradition; and Gilbert, 1998 , for a detailed view on extradition processes.

188 Gilbert, 1991, 8.

189 See e.g. Sambei, Du Plessis and Polaine, 2009, 406; Murphy, 1985, 36. However, extradition without a treaty is also possible. Oppenheim, Jennings and Watts, 1992, 951, 957. 
treaties bear resemblance to one another, as they typically were created based on the French model. ${ }^{190}$

The extradition process is regulated through domestic legislation or self-executing treaties in municipal courts. ${ }^{191}$ In addition to extradition based on treaties, some states, such as the United States, may extradite fugitives even without the existence of a treaty between the requesting and requested state, depending on specific provisions in its national legislation. ${ }^{192}$

Extradition aims at ensuring the application of criminal law. It is a means to secure "that the preventive, educative or expressive uses of the criminal law are not diluted by the recurrent spectacle of offenders managing to avoid trial by fleeing to a foreign sanctuary." ${ }^{193}$ As such, it also forms a part of the procedural framework of international criminal law. ${ }^{194}$

There are two ways of looking at extradition. On the one hand, it can be seen as a tool serving a common global interest in guaranteeing that justice is served. This would require the existence of an internationally shared social or moral order. ${ }^{195}$ As a consequence, one of the roles of national criminal laws would be to secure that common order. On the other hand, extradition can be seen as a form of international cooperation aiming at supporting reciprocal self-interest. It is in the interest of each state to be able to execute its criminal law. In order to gain its fugitives back, the state, however, needs to assist others with the same aim. ${ }^{196}$ As Boister has argued, the enforcing of the criminal laws of a state is an expression of their sovereignty. Extradition as a process is interesting because it forces states to rely on the sovereign decision-making of other states to be able to enforce their national laws against those criminals who cross borders. ${ }^{197}$

In the past, extradition typically formed a part of a treaty concerning another matter. The first multilateral convention that dealt also with extradition was the Treaty of Amiens of 1802. However, its extradition article was never put into

190 Freestone, 1981, 206. See also American Journal of International Law, Introductory Comment, Supplement, 1935, 45.

191 Gilbert, 1991, 1.

192 See The Restatement (Fourth) of Foreign Relations Law of the United States: Jurisdiction $\$ 312$, Tentative Draft No 3 (2017): “The United States generally extradites only pursuant to treaties. A narrow statutory exception to this practice authorises the extradition of persons other than citizens, nationals, or permanent residents of the United States who have committed crimes of violence against U.S. nationals in foreign countries, upon certification by the Attorney General." See also 18 U.S.C. \$ 3181(b). Gilbert, 1991, 125; Oppenheim, Jennings and Watts, 1992, 968; Gilbert, 1998, 227. See more on self-executing treaties in the US in e.g. Blakesley, 2007, 266-275; and Blakesley, 2002, 541. See for a detailed history of US extradition practice Nadelmann, 1993.

193 Bassiouni, Wise, 1995, 26. See also e.g. Gilbert, 1991, 3.

194 Gilbert, 1991, 3.

195 Bassiouni and Wise, 1995, 26-28.

196 See Pyle, 1986 and 2001.

197 Boister, 2015, 11. 


\section{Concepts employed}

force due to war. ${ }^{198}$ The Webster-Ashburton treaty of 1842 between the US and Great Britain that covered a variety of issues concerning the US-British North American (later Canadian) border had an article that covered the extradition of those wrongdoers charged with murder, assault with intent to commit murder, piracy, arson, robbery, forgery and utterance of forged paper. ${ }^{199}$ Little by little, treaties concentrating solely on extradition were signed. The first US treaty that dealt solely with extradition was the 1843 treaty with France. ${ }^{200}$ The first multilateral treaty that concentrated exclusively on extradition was the Treaty on Extradition Signed in Lima, Peru, 1879, which was signed by nine Central and Southern American states. ${ }^{201}$

Several treaties dealing with international crime have included extradition as a central tool. For instance, in the UN Conventions that relate to terrorism, extradition is a key element in dealing with terrorist deeds. Other treaties that mention extradition as a key control mechanism include the Geneva Conventions of $1949 . .^{202}$

Extradition has a dual function: legal and diplomatic. A decision to extradite is never a purely judicial matter, as it affects and is affected by questions of foreign policy. ${ }^{203}$ Christopher H. Pyle has claimed that extradition is highly political and it lies at the intersection of international politics, ethnic politics and interbranch rivalries. $^{204}$

The political nature of extradition is visible in the process of allowing extradition. According to Bassiouni, the closer the political systems of the requesting and requested states are, the less likely it is that the crime will be considered a political offence and the more likely it is that extradition is granted. ${ }^{205}$ For instance, it has

198 See for a short history of multilateral extradition conventions American Journal of International Law, Introductory Comment, Supplement, 1935, 47-48. See also Zanotti, 2006, 1 , on the Amiens treaty.

199 Webster-Ashburton Treaty, 9 August 1842; Abbell, 2010, 3.

200 Convention for the Surrender of Criminals between the United States of America and His Majesty the King of the French, 8 Stat. 580 (1844), 9 November 1843.

201 Zanotti, 2006, 1. The Lima treaty was adopted by the American Congress of Jurists and was signed by the representatives of Argentina, Bolivia, Chile, Costa Rica, Ecuador, Guatemala, Peru, Uruguay and Venezuela. Zanotti, 2006, 5. A detailed list of multilateral conventions and treaties that deal with extradition can be found in Zanotti, 2006.

202 Article 49, second paragraph, of the 1949 Geneva Convention I; Article 50, second paragraph, of the 1949 Geneva Convention II; Article 129, second paragraph, of the 1949 Geneva Convention III; and Article 146, second paragraph, of the 1949 Geneva Convention IV provide: "Each High Contracting Party shall be under the obligation to search for persons alleged to have committed, or to have ordered to be committed, such grave breaches, and shall bring such persons, regardless of their nationality, before its own courts. It may also, if it prefers, and in accordance with the provisions of its own legislation, hand such persons over for trial to another High Contracting Party concerned, provided such High Contracting Party has made out a prima facie case."

203 See e.g. Van den Wijngaert, 1980, 39; Freestone, 1981, 206; Pyle, 2001, 155.

204 Pyle, 2001, viii. See also Nadelmann, 1993, 815-816.

205 Bassiouni, 1969, 232, 249. 
been shown that communist countries categorically refused to extradite nationals to non-communist countries. ${ }^{206}$ Further, Bassiouni has claimed that the refusal or allowing of extradition has always been more a matter of political interests than a matter of objective judicial decision-making or of pondering the rights of the individual concerned. ${ }^{207}$

Due to the legal-diplomatic duality, there is variance in whether the decision to extradite belongs to the judiciary or to the executive. In the US, the courts decide on the extraditability of a person and the Secretary of State decides on whether the fugitive is surrendered. The courts' role has been criticised for instance by William M. Hannay who has argued that "a courtroom is an inappropriate forum in which to attempt an evaluation of the complex internal political struggles of foreign countries." ${ }^{208}$ Similarly, Cindy Schlaefer has seen a serious problem with the judiciary resolving political issues, as in the case of applying the POE to for instance terrorism, the decision-making will always be political. ${ }^{209}$

In contrast, Christopher L. Blakesley has supported the role of US courts in the application of the POE:

True, if the judiciary must make this decision, it might make a mistake. A mistake would be tragic. However, even if the government believes the Executive Branch would not make such mistakes, it seems the judiciary, armed with jurisprudence developed over the past two hundred years and the constitutional mandate to decide such issues of fact and law, is best equipped to render just decisions case by case. More important, failure to leave this as a judicial prerogative is a failure to abide by our primordial constitutional principles of checks and balances, the separation of powers, and the notion that questions of law and fact relating to human liberty are within the province of the judiciary. ${ }^{210}$

In principle, the role of the judicial inquiry is to make sure that the extradition request fills the criteria laid down for it. The aim is not to evaluate the guilt or innocence of the requested person. However, this is truer with regard to continental systems. Common-law countries have tended to require that all initiations of legal processes satisfy certain standards, thus fulfilling the probable cause requirement. In other words, an extradition decision should be based on reasonable grounds to believe that the fugitive is guilty of the crime accused. These criteria are not easy to satisfy.

206 Gold, 1970, 196.

207 Bassiouni, 1969, 232.

208 Hannay, 1980, 383. See also e.g. Lubet, 1982, 281.

209 Schlaefer, 1981, 642-643.

210 Blakesley, 1986, 123. 


\subsubsection{Extradition and human rights protections}

Extradition is a process between two states. The fugitive, whose extradition is sought, is at the core of the process, but until recently, the rights of this individual were not of major concern. Nowadays these rights are growingly taken into account but they are always weighed against the interests of the states concerned, as well as against the interest of the world community in preserving the global order. ${ }^{211}$ For this reason, there is always tension between the rights of the fugitive and the interests of the state in suppressing crime. ${ }^{212}$ The extradition procedure is an official procedure and, as such, it has to take into account the rights of the fugitive. Extradition treaties typically contain clauses that aim at protecting the human rights of the person sought for extradition. These include, for instance, the double criminality principle, the political offence exception and the discrimination clause. ${ }^{213}$ Even without specific clauses, international human rights rules regulate extradition processes. However, the main concern of these limitations has been, first and foremost, to create protection for the sovereignty of the state rather than for the protection of the individual. ${ }^{214}$ Transnational crime suppression conventions aim principally at suppressing crime and it remains a duty of the states to protect the human rights of individuals. ${ }^{215}$ It is left to the state to decide whether to breach its duties under the suppression convention or to act according to international law. ${ }^{216}$

Since the Second World War, the rights of individuals have become growingly protected. However, as pointed out by Currie, for a long time, the duty of a state to protect the human rights of a fugitive was connected only to its territory. Once the person was extradited, the duty practically vanished. Legal decision-making in the 1980s and 1990s changed this perspective. For example, the famous case of Soering decided upon by the European Court of Human Rights extended the duty of concern over the human rights of the fugitive: the states that are parties to the ECHR are now considered to be bound by human rights norms upon their participation in international collaboration. ${ }^{217}$

In international law, the primary concern is nowadays always to protect the rights of individuals, as opposed to facilitate extraditions. This is because the human rights norms arise from notions of jus cogens. Such a viewpoint has been

211 Bassiouni, 1973, 25. See Gilbert, 1998, 147-174; and Dugard and Van den Wijngaert, 1998,188 , for more details concerning the relation between extradition and human rights.

212 Dugard and Van den Wijngaert, 1998, 187. See Blakesley, 2000, for a thorough discussion on the topic.

213 Boister, 2002, 202. See in more detail about the double criminality principle e.g. Blakesley, $2000,40-49$.

214 Blakesley, 2000, 2-4.

215 See in more detail on the protection of human rights in the crime suppression conventions e.g. Boister, 2002; and Currie, 2015, 28-34.

216 Boister, 2002, 219.

217 Soering v. the United Kingdom, Application no. 14038/88, 7 July 1989. See also Blakesley, 2000, 64-69; Boister, 2002, 204-205; and Currie, 2015, 36. 
supported by scholarly writing on the Soering case and by statements made by three premier nongovernmental international law associations: the Institute of International Law, the International Law Association and the International Association of Penal Law. ${ }^{218}$

Boister has suggested that the Soering case could have had a more global effect through the case of $\mathrm{Ng} v$. Canada. In $\mathrm{Ng}$, the UN Human Rights Committee endorsed the Soering approach and decided that the extradition of $\mathrm{Ng}$ to California, where he could have faced death row and been executed by gas asphyxiation, represented a breach of Canada's duties under the International Covenant for Civil and Political Rights (ICCPR). However, the US has been opposed to this interpretation in the application of the ICCPR. ${ }^{219}$

Regardless of the strengthening of human rights norms during the past decades, the rights of the individuals have in many cases been pushed to the side. Especially since the terrorist attacks against the US in 2001, new methods that have been considered more efficient in the fight against terrorism have been used in the transfer of suspected terrorists. ${ }^{220}$ Unlawful seizures and irregular rendition devices have been used as alternatives to extradition since the 1970s and 1980s. ${ }^{21}$ Since that period, military language has been commonly applied to the fight against crime. Wartime metaphors have facilitated the ignorance of the presumption of innocence and as well as the use of the law as an instrument of oppression. ${ }^{222}$

These 'alternative' methods do not provide the same legal safeguards for fugitives' rights as the extradition process does. ${ }^{223}$ Their nature is mostly extralegal or illegal, and they are typically resorted to when legal means of rendition are exhausted. ${ }^{224}$ Deportation, for instance, has been an important method

218 Dugard and Van den Wijngaert, 1998, 194-195.

219 Boister, 2002, 205. See also Chitat Ng p. Canada, Communication No. 469/1991, U.N. Doc. CCPR/C/49/D/469/1991 (1994).

220 Currie, 2015, 37.

221 M. Cherif Bassiouni has classified these into three categories: "(1) the abduction and kidnapping of a person in one state by agents of another state; (2) the informal surrender of a person by agents of one state to another without formal or legal process; and (3) the use of immigration laws as a device to directly or indirectly surrender a person or place him in a position in which he or she can be taken into custody by the agents of another state." Bassiouni has strongly criticised these methods: "Aside from the flagrant violation of the individual's human rights, these practices affect the stability of international relations and subvert the international legal process." States using kidnapping as a rendition technique while simultaneously on the official level calling kidnappings terrorism hardly strengthens trust in the international legal system. Bassiouni, 1973, 26-27. For more details see e.g. Bassiouni, 1973; Van den Wijngaert, 1980, 50-63; Freestone, 1981, 204-205; Murphy, 1985, 81-93; Gilbert, 1991, 182-207; Nadelmann, 1993, 857-882; and Gilbert, 1998, 337-377.

222 Pyle, 2001, 146.

223 Freestone, 1981, 205; Gilbert, 1991, 4; Sambei, Du Plessis and Polaine, 2009, 407.

224 Bassiouni, 1973, 62. See Oppenheim, Jennings and Watts, 1992, 940-948, on the rules of international law concerning the expulsion of aliens. 
in bringing offenders to trial. As it is a simpler procedure than extradition, it has often been used by states willing to collaborate in capturing terrorists but unwilling to use the complicated method of extradition. ${ }^{225}$ McElrath has claimed that extradition and deportation are not separate from one another, but that deportation is merely the substitute for situations where extradition fails. ${ }^{226}$

Since the early years of the 21 st century, a new concept which relates to the surrender of suspected terrorists has emerged, the so-called extraordinary rendition. The concept is usually understood as the removal of a terrorist without judicial supervision. Extraordinary rendition is used instead of extradition to avoid judicial limitations such as the application of specific human rights norms such as norms regulating the status of prisoners of war or the political offence exception. $^{227}$

The legality of these methods in the surrendering of fugitives is disputable. For instance, Basso has suggested that deportation can legally be used instead of extradition. According to her, different ideologies lay behind deportation and extradition. Even if both have the same result, removing a person from the country, they serve different purposes. ${ }^{228}$ The difference between extradition and deportation is that only aliens can be deported, whereas, for instance, the US law allows for the extradition of nationals. ${ }^{22}$ The US has used deportation in cases where a foreign nation with which it does not have an extradition treaty has demanded the return of a fugitive. ${ }^{230}$

The purpose of deportation is to remove a person who is unwanted in a specific country, without a need for punishment. In extradition, a fugitive is surrendered for trial or for the execution of a punishment. For this reason, deportation can never substitute for extradition. Someone who cannot be extradited can still be deported. ${ }^{231}$ Additionally, in extradition, the fugitive is delivered to the requesting state, whereas a deportee can typically choose the state where they go. ${ }^{232}$ Deportation is used as a substitute for extradition typically in cases which concern two neighbouring states, where it is easy to transfer the deportee. ${ }^{233}$

Even if deportation as an alternative to extradition seems like a path around legal norms, deportees are still protected by human rights rules. For instance, the Convention Against Torture prohibits the extradition or expulsion of a person

225 Freestone, 1981, 205.

226 McElrath, 2000, 64.

227 See in more detail e.g. Borelli, 2014, 363. See also Boister, 2002, 203.

228 Basso, 1989, 330-332.

229 Epps, 1979, 76.

230 Basso, 1989, 332.

231 Basso, 1989, 330-331; see also e.g. Epps, 1979, 76; Oppenheim, Jennings and Watts, $1992,945$.

232 Epps, 1979, 76.

233 Oppenheim, Jennings and Watts, 1992, 947. 
"to a State where there are substantial grounds for believing that he would be in danger of being subjected to torture." 234

During the 20th century, especially immediately after the Second World War, international human rights law and the limitations to the powers of states visà-vis their subjects developed in big leaps. ${ }^{235}$ During this period, new means of protecting individuals from states emerged. With regard to expulsion, the principle of non-refoulement saw daylight, ${ }^{236}$ and with regard to extradition, the discrimination clause was created. Additionally, the principle of refuge was also laid down. ${ }^{237}$

The discrimination clause, created and modified based on Article 33 of the Refugee Convention, ${ }^{238}$ extended the protection of fugitives to those who risked getting discriminated based on their political ideologies. It is applicable in situations where it is suspected that the person is sought for the purpose of prosecuting them for a political offence, or that their extradition might result in their prosecution on grounds of race, religion, nationality, political opinions or other comparable reasons, or if one of these reasons could affect the way the person is treated in the requesting country. ${ }^{239}$ The discrimination clause has also been labelled as the "equal protection clause" 240 or the "freedom from persecution clause." ${ }^{241}$ A related clause was already suggested in 1880 by the Institute of International Law at its Oxford meeting. In its final resolutions, this authoritative institute affirmed that in order to extradite someone for the commission of a political crime, the requesting state should assure that the person extradited would not be brought to "des tribunaux d'exception." 242

The discrimination clause partially overlaps with the POE. However, their purposes are different. The POE was created to protect those who commit

234 Article 3, Convention against Torture and Other Cruel, Inhuman or Degrading Treatment or Punishment (CAT), A/RES/39/46, 10 December 1984.

235 Van den Wijngaert, 1980, 18; see also e.g. Galgani, 2013, 182-183.

236 See Article 33, United Nations Convention Relating to the Status of Refugees, 28 July 1951.

237 See the following section on the concept of refuge.

238 United Nations Convention Relating to the Status of Refugees, 28 July 1951. See also Kälin and Künzli, 2000, 68.

239 See e.g. the wording in the France-Israel treaty of 1958, Article 4: "L'extradition ne sera pas accordée lorsque l'Etat requis considérera que les éléments de l'infraction ou les motifs de la demande sont fondés sur des considérations politiques, raciales ou religieuses." Convention d'extradition entre la France et l'état d'Israél, 12 November 1958. See also e.g. Pyle, 1988, 188. A landmark case applying the discrimination clause concerned Soering, who fled to the UK after allegedly murdering his girlfriend's parents in the US. His case was referred to the ECHR based on the claim that he would risk being subjected to inhuman or degrading treatment by being kept on death row for an extensive period of time. The ECHR decided that the UK should not extradite Soering. See in more detail Dugard and Van den Wijngaert, 1998, 191-192.

240 Petersen, 1992, 773.

241 See e.g. Gilbert, 1991, 152-153.

242 Article 15, Justifia et Pace, Institut de Droit International, Session d'Oxford, Résolutions d'Oxford (Extradition), 9 September 1880. 
political offences, whereas the discrimination clause can also protect common offenders, should their treatment be prejudiced in one way or another if extradited. Additionally, the POE protects offenders entirely from being prosecuted, whereas the discrimination clause protects them from unfair trials.

The discrimination clause was first introduced in the European Convention of Extradition in 1957, and its historical roots can be found in the French law on extradition of 1927. The principle is based, similar to the POE, on the consideration that all political offenders might not receive a fair trial, especially in the state whose interests they have attacked. ${ }^{243}$

The discrimination clause prevents the political uses of the trial process and guarantees the due process of law. However, states have been reluctant to use this clause, as it means taking a stand on the judicial process of another state and its internal dynamics and could, for this reason, result in unwanted diplomatic incidents. The existence of the clause seems to demonstrate an inherent element of mistrust between treaty partners. It has also been criticised for mixing judicial matters with wider political interests. ${ }^{244}$

Since the introduction of the discrimination clause to the European Convention on Extradition in 1957, similar provisions have emerged in some US treaties. ${ }^{245}$ The discrimination clause is now a common addition in many extradition treaties. ${ }^{246}$ However, it has not been commonly used by the US, as US courts have been tied by the rule of non-inquiry, preventing them from evaluating the fairness of a foreign judicial system. ${ }^{247}$

A nearly identical legal construction to the discrimination clause is the nonrefoulement principle. The UNHCR, the United Nations Refugee Agency, 1951 Convention Relating to the Status of Refugees includes the following clause: "No Contracting State shall expel or return ("refouler") a refugee in any manner whatsoever to the frontiers of territories where his life or freedom would be threatened on account of his race, religion, nationality, membership of a particular social group or political opinion." 248 However, the non-refoulement only applies to political refugees, whereas the non-discrimination only protects fugitives who

243 Van den Wijngaert, 1980, 2-3. See also Abbell 2010, 119; and Galgani, 2013, 182-183.

244 Freestone, 1981, 213-216; Petersen, 1992, 774; Galgani, 2013, 183-184.

245 The first one was the Jamaica International Extradition Treaty with the United States, 14 June 1983. See also Abbell, 2010, 119; Galgani, 2013, 182.

246 Gilbert, 1991, 152-153.

247 Blakesley has commented this rule in the following way: "[The rule of non-inquiry] is applied by courts to avoid considering the propriety of extradition, when questions about the fairness of the requesting state's justice system are raised. The requested state sees its interest in not embarrassing the requesting state as being stronger than the fugitive's interest injustice or fairness." Blakesley, 2000, 5.

248 Article 33(1), Convention Relating to the Status of Refugees, 28 July 1951. However, the principle of non-refoulement does not limit the actions of the state upon the refugee in other ways. The state may refuse asylum, or send the person elsewhere or even imprison them. The only restriction this principle offers is that the refugee cannot be returned to where they are likely to be persecuted. Stanbrook and Stanbrook, 2000, 93. 
are sought for punishment or prosecution. ${ }^{249}$ As a principle of customary international law, the non-refoulement principle is binding upon all states, whether they are signatories of the convention or not. ${ }^{250}$

A similar clause to the non-refoulement clause had already been incorporated into the 1933 League of Nations Convention on the International Status of Refugees. This principle was used in the latter part of the decade to protect refugees from Nazi Germany and from Spain during its civil war. ${ }^{251}$

In addition to the POE and the discrimination clause, there are several grounds based on which states can deny extradition provided in treaties. For instance, states can deny extradition based on domestic policy considerations. Most states are, problematically, ${ }^{252}$ opposed to the extradition of their own nationals due to considerations of national sovereignty, domestic policy and political considerations. This practice of non-extradition of nationals has existed as long as the practice of extradition itself and is the most common in civil law jurisdictions. ${ }^{253}$

Like the practice of non-extradition of political offenders, this practice can also be seen as a reflection of mistrust between states. Partly it is a result of similar concerns as the POE or the discrimination clause: the fear of unfair treatment in the receiving state. ${ }^{254}$ It protects the right of the state to exercise jurisdiction over its own nationals and the nationals from being surrendered to a foreign jurisdiction. At the same time, however, it can also protect the perpetrators of serious crimes. ${ }^{255}$

Regardless of the controversies that relate to its application, many nations refuse to extradite their own nationals. This principle has also formed a part of many international extradition conventions, such as the European Convention on Extradition of $1957^{256}$ and the UN Model Treaty on Extradition of $1990 .{ }^{257}$ In the 1996 European Union Extradition Convention, the right to refuse extradition based on the nationality of the offenders was denied. However, this provision was still subject to reservations. ${ }^{258}$

The principle has proved to be extremely problematic, especially with regard to the extradition of perpetrators of international crimes. The system of international

249 Van den Wijngaert, 1980, 66. See in more detail regarding the position of the political offender vis-à-vis human rights rules Van den Wijngaert, 1980, 66-93. See also Oppenheim, Jennings and Watts, 1992, 971.

250 Stanbrook and Stanbrook, 2000, 93.

251 Article 3 Convention relating to the International Status of Refugees, 28 October 1933. League of Nations, Treaty Series Vol. CLIX No. 3663. See also Stanbrook and Stanbrook, 2000, 92.

252 One example of the problems caused by the usage of this principle is the denial of Libya to extradite its own nationals for the purposes of trial after the Lockerbie bombing in 1988 . Plachta, 1999, 130-132.

253 Deen-Racsmány, 2007, 3. See Shearer, 1966; Nadelmann, 1993, 847-857; Plachta, 1999; and Deen-Racsmány, 2007, for more details the practice of non-extradition of nationals.

254 Nadelmann, 1993, 847; Plachta, 1999, 99.

255 McDermott, 2015, 291.

256 European Convention on Extradition, ETS No. 24, 13 December 1957.

257 UN Model Treaty on Extradition. Annex: A/RES/45/116, 14 December 1990.

258 Article 7 Convention, drawn up on the basis of Article K.3 of the Treaty on European Union, relating to extradition between the Member States of the European Union, Dublin, 27 Sept. 1996, O.J. 1996, C 313/12. 
courts cannot function if criminals are sheltered within the borders of their own nation states. ${ }^{259}$ A suggested solution for the problems created by the application of this principle has been the introduction of the aut dedere aut judicare clause in a number of international legal instruments. This principle obliges states to either extradite persons found on their territory, wanted for trial by another state for an extraditable offence or to try the fugitives themselves. ${ }^{260}$ However, the application of this principle is not without problems, either. ${ }^{261}$

Similar to the POE, this principle has also ceased to exist within the European Union with the coming into existence of the European Arrest Warrant (EAW). ${ }^{262}$ As with the elimination of the POE, the evisceration of this principle can be seen to reflect shared cultural values and mutual trust between European states. ${ }^{263}$

There is a strong link between human rights law and terrorism. First, an act of terrorism clearly undermines the human rights of the victims. Second, the prevention and the combatting of terrorism can be executed in such a manner that the human rights of the suspects are seen as secondary to the goal of punishing the perpetrators. For this reason, human rights concerns with regard to the battle against terrorism have become central to the $\mathrm{UN}$, for instance. ${ }^{264}$

\subsubsection{POE versus political refuge: different legal constructions}

In many instances, the concepts of invoking of the POE and providing asylum are blurred, and the concept of political refuge and the principle of non-extradition of political offenders are entangled. ${ }^{265}$ The application of the POE is even sometimes referred to as political asylum. ${ }^{266}$ Many writers seem to equate the invoking of the POE with offering refuge to the fugitive. ${ }^{267}$ In 1982, Steven Lubet wrote: "In fact,

259 Deen-Racsmány, 2007, 8.

260 The aut dedere aut judicare principle obliges states to either extradite persons found of their territory who are wanted for trial for an extraditable offence by another state or to try the fugitives themselves. Oppenheim, Jennings and Watts, 1992, 953. See on the principle and its history in more detail e.g. Bassiouni and Wise, 1995; and Plachta, 1999, 123-140.

261 See Dugard and Wijngaert, 1998, 209-210.

262 Council Framework Decision of 13 June 2002 on the European Arrest Warrant and the Surrender Procedures between Member States - Statements Made by certain Member States on the Adoption of the Framework Decision, 2002/584/JHA, OJ L 190, 18 July 2002.

263 It is interesting to note that the practice of non-extradition of nationals was persistent between Communist states. See Plachta, 1999, 101-102.

264 See Nuotio, 2006, 1004-1005. See in more detail on infringements of human rights during the course of terrorism investigations Sambei, Du Plessis and Polaine, 2009, 352-371.

265 Gilbert has pointed out that "both popularly and even judicially, the right to asylum is confused with the principle of non-refoulement, which does not help make for a clear analysis." Gilbert, 1991, 233. See Gilbert, 1991, 231-244; Nicholson and Twomey, 1999; and Li, 2017, 91-111, for details on refugee law in relation to extradition law; and Gilbert, 2014, for a discussion on the link between terrorism and refugee law. See in more detail regarding the links between the Refugee Convention and the POE Kälin and Künzli, 2000.

266 Van den Wijngaert, 1980, 71.

267 See e.g. García-Mora, 1956, 2; Bassiouni, 1969, 232; Gold, 1970, 197; Stanbrook and Stanbrook, 2000, 16. 
the principle that a nation should not deliver a political offender to the government against which he has taken up arms is held so universally that we now commonly may speak of a right of political asylum. Thus, the political offence exception is a concept which is involved intimately with the international protection of human rights."268

Similarly, in 1909 Assistant Solicitor of the US Department of State Reuben J. Clark argued that "[ the general purpose of the political clause in extradition treaties appears to be to provide against the surrender of political refugees for punishment for political crimes." ${ }^{269}$ Here Clark was using the concept of refugee as synonymous with the concept of fugitive. Even if in Clark's time these concepts were related and used interchangeably, ${ }^{270}$ nowadays they have different meanings. However, in some cases, the two concepts may also overlap. A person might be of the opinion that they are a refugee, but the state requesting their extradition would consider them a fugitive.

The concept of asylum is older than the protection of political offenders. During religious wars, other states offered refuge to those targeted for their faith. Slowly, the idea of asylum evolved, but for a long time, it did not concern criminal fugitives. ${ }^{271}$ Asylum can be defined as "protection which a state grants to a foreign citizen against his own government." 272

The core in both the protection of refugees and of political offenders is the same: trying to protect a person from unfair treatment from political opponents. However, the legal rules protecting them are different. ${ }^{273} \mathrm{~A}$ political offender seeking refuge is not a, strictly speaking, a refugee. The political criminal has always committed an offence, whereas the political refugee cannot return to the country of his origin because he is persecuted because of his political convictions or other personal reasons, such as religion. ${ }^{274}$ Thus the political offender is an active part in a political conflict, whereas the refugee is a passive victim of persecution. ${ }^{275}$

268 Lubet, 1982, 283.

269 Clark, 1909, 109.

270 In fact, in the Introductory Comment to the Supplement on extradition in the American Journal of International Law in 1935, asylum is linked "only to those who have committed political or military offen[c]es." It also noted that prior to the emergence of the POE, the right of asylum had also protected common criminals. American Journal of International Law, Introductory Comment, Supplement, 1935, 45-46, italics added.

271 Van den Wijngaert, 1980, 6-7.

272 García-Mora, 1956, 1.

273 Van den Wijngaert, 1980, 28. See in more detail concerning the differences between refuge and the protection of political offenders e.g. Gilbert, 1998, 431-450. See also Gil v. Canada (M.E.I.), [1995] l F.C. 508 (F.C. Appeal).

274 See Article 1, United Nations Convention Relating to the Status of Refugees, 28 July 1951 , which defines a refugee as a person "owing to wellfounded fear of being persecuted for reasons of race, religion, nationality, membership of a particular social group or political opinion, is outside the country of his nationality and is unable or, owing to such fear, is unwilling to avail himself of the protection of that country; or who, not having a nationality and being outside the country of his former habitual residence as a result of such events, is unable or, owing to such fear, is unwilling to return to it." See on the discussion on the interpretations of the concept e.g. Sztucki, 1999.

275 Van den Wijngaert, 1980, 27-28. 


\section{Concepts employed}

Geoffrey Gilbert has spelled out the distinction between asylum in the more general sense and asylum as a legal concept: "Asylum in its colloquial sense means a decision not to expel or deport an alien to a state where he might be persecuted; under Article 33 of the 1951 Convention Relating to the Status of Refugees, this obligation is termed non-refoulement. Asylum is much more serious measure in that it grants to the refugee rights approaching those of a national."276

Similarly, M. Cherif Bassiouni has made a distinction between "asylum in the sense of permission by one state to an individual to enter its territory or remain therein when such individual is not sought by another state" and "asylum in the sense of allowing a person sought by a state to be shielded from its processes by a denial of extradition." 277

Formal refugee status protects the person from extradition. In this regard, being granted asylum has the same result as invoking the political offence exception to extradition. ${ }^{278}$ However, the denial of extradition does not automatically mean the person is granted asylum. ${ }^{279}$ The state can decide whether it wants to grant asylum in addition to denying extradition. This decision depends on two key factors: First, what effect would the granting of asylum have on the foreign relations of the requested and requesting states? Is the fugitive worth that disruption? How important are the values that the protection of the fugitive represents to the protecting state? Second, would providing refuge compromise the national public order of the receiving state? ${ }^{280}$

If the requested person is not extradited, they can still be deported under asylum laws. This is common, even if, arguably, it is not something that should be a part of US practice, for instance. ${ }^{281}$ Some have argued that granting the political offence exception should also mean granting asylum. ${ }^{282}$ As discussed earlier, sometimes extradition is formally denied, but the fugitive is still expelled through extralegal procedures. Some judges have promoted the idea that refugee and asylum principles could be used when evaluating the political nature of an offence. ${ }^{283}$

States are not bound by either the POE or the idea of asylum. As discussed earlier, the invoking of the POE is dependent on treaty provisions and the states' political decisions. With regard to asylum, it remains unclear if international law, in fact, establishes a duty to protect. Whether such a right exists depends on the circumstances and the state of refuge and on how international law is

276 Gilbert, 1991, 232-233.

277 Bassiouni, 1969, 233. See also Li, 2017, 21-23.

278 Bassiouni, 1969, 231; Stanbrook and Stanbrook, 2000, 96. Sometimes similar considerations have been used in both cases, see Gilbert, 2014, 479.

279 Bassiouni, 1969, 231-234; Murphy, 1985, 41.

280 Bassiouni, 1969, 234.

281 Epps, 1979, 78; Epps, 1988, 207-208; McElrath, 2000, 46.

282 García-Mora, 1956, 78.

283 Gilbert, 1991, 231. 
interpreted. Traditionally, it is seen that the receiving state can decide whether it offers asylum. ${ }^{284}$

Many states' legislation provides the right to asylum for persons persecuted for political reasons. However, the Universal Declaration of Human Rights only provides the right to seek asylum from persecution, but not the right to gain asylum. ${ }^{285}$ The same applies to the Declaration on Territorial Asylum of 1967. 286 Nonetheless, it is possible to claim that any foreign state is provisionally an asylum to an individual fleeing their home country, as all states hold territorial supremacy over those who reside on their territory. ${ }^{287}$

The difference between offering asylum to a refugee and invoking the nonrefoulement principle discussed earlier is that the non-refoulement principle does not prevent the state from sending a person to another state as long as his life or freedom is not threatened there. ${ }^{288}$ Additionally, the Refugee Convention does not seem to have an impact on extraditions as its Article l(F)(b) limits its protection of the entire convention from those "with respect to whom there are serious reasons for considering that $[\ldots]$ he has committed a serious nonpolitical crime outside of the country of refuge prior to his admission to that country as a refugee." Additionally, the non-refoulement clause is especially limited so that it does not protect a person who, based on reasonable grounds, is regarded as a danger to the security of the receiving country or has committed a "particularly serious crime." 289 Most extraditable offences are these types of serious offences. However, it once again seems that the definition of a 'nonpolitical' offence or 'particularly serious crime' is left to the state deciding upon offering refuge.

Comparably, according to the Universal Declaration of Human Rights (UDHR), asylum cannot be used to avoid prosecution for non-political crimes or other acts "contrary to the purposes and principles of the United Nations." 290 The Declaration on Territorial Asylum also limits the right to asylum in a similar manner but does not exclude those struggling against colonisation from its scope. ${ }^{291}$ The UN Security Council Resolution 1373 of 2001 excluded terrorists from the protection of the refugee status. ${ }^{292}$

These limitations aim at protecting the receiving community from accepting a dangerous person. Simultaneously, they make it possible to shelter those who

284 Gilbert, 1991, 233-236. See also Li, 2017, 24-49.

285 Article 14, UDHR 10.12.1948, GA Res 217 A.

286 Declaration on Territorial Asylum, UN GA Res 2312 (XXII) 14 December 1967.

287 Oppenheim, Jennings and Watts, 1992, 901. See generally on the status of refugees in international law pp. 890-896 and Li, 2017.

288 Gilbert, 1991, 238. See in more detail, Li, 2017, 101-103.

289 Article 33(2), Convention Relating to the Status of Refugees, 28 July 1951.

290 Article 14 (2), UDHR, 10 December 1948, A/RES/217 (III).

291 Article 1, Declaration on Territorial Asylum, 14.12.1967, A/RES/2312 (XXII).

292 UN Security Council Resolution 1373 Threats to International Peace and Security Caused by Terrorist Acts. UN Doc. S/RES/1373, 28 September 2001. 


\section{Concepts employed}

have committed less serious common crimes or political offences. ${ }^{293}$ Some have claimed that one of the possible purposes in creating these conventions has also been to protect politically motivated offenders from oppressive regimes. ${ }^{294}$ In this way, the Refugee Convention, the UDHR and the POE meet.

\subsubsection{History of the extradition of political criminals}

Extradition itself has a long history. Early extradition served as an "arbitrary tool of kings by means of which they sought to gain control of persons who had offended them." ${ }^{295}$ Until the French Revolution, political crimes were seen as the most heinous of all crimes. By threatening the entire state and not just individuals, they potentially could create chaos. For this reason, special tribunals and severe punishments were required for political crimes. Political crimes had a specific name, crimen majestatis (crimes de lèse-majesté, crimes contre la sûreté de l'état), crimes against the divine right of governments. Because of the severity of their crimes, the capturing of political criminals was seen as a priority. This triggered the birth of the tradition of extradition centuries ago. The practice was already known in Egyptian, Chinese, Chaldean and Assyro-Babylonian civilisations. ${ }^{296}$

Most extradition treaties were designed to return political offenders to their country of origin for punishment. For instance, the treaty of 1834 between Prussia, Austria and Russia stated, "All persons that, in Austria, Russia and Prussia have been found guilty of a crime of high treason, capital treason or armed rebellion, or a member of an association whose purpose is directed against the security of the throne and the government, will not find protection or asylum in the other states. The parties reciprocally agree to surrender all persons accused of such crimes." A similar clause can be found in the 1828 treaty between Switzerland and France. ${ }^{297}$ These treaties were amongst the last ones to concentrate on political offences.

The extradition for common crimes was not equally important as for political offences, as they did not create a threat to the public order and they were usually prosecuted only by the victims. In addition, not that many common criminals fled the country, as exile was a harsh penalty in itself; the rights states offered to foreigners were scarce. ${ }^{298}$

Only at the end of the 18th and at the beginning of the 19th century did extradition treaties for common crimes emerge as a part of diplomatic practice between states. ${ }^{299}$ Until then, the sovereignty of nations and the principle of non-

293 Handbook on Procedures and Criteria for Determining Refugee Status under the 1951 Convention and the 1967 Protocol relating to the Status of Refugees, HCR/IP/4/Eng/REV.1 Reedited, Geneva, January 1992, UNHCR 1979.

294 See Steinbock, 1999, for a discussion on the matter.

295 Deere, 1933, 249.

296 See e.g. Ferrari, 1920, 311; Deere, 1933, 249; Epps, 1979, 62; Van den Wijngaert, 1980, 5.

297 García-Mora, 1956, 74.

298 Van den Wijngaert, 1980, 5; Oppenheim, Jennings and Watts, 1992, 951.

299 Epps, 1979, 62; Van den Wijngaert, 1980, 5-7. 
interference in the matters of another state were seen as more fundamental than the need to capture criminals. ${ }^{300}$ The extradition of common criminals became more important when criminals moving across borders started to seriously affect states' economic interests. This created a common interest for the suppression of crime. ${ }^{301}$ Thus the growing use of the practice of extradition arose from an increased interdependence between states.

A typical extradition treaty from the mid-19th century onwards included a list of offences that created a duty to extradite to the contracting state. Such a list ordinarily included crimes such as murder, arson, bigamy and embezzlement. The list system persisted throughout the 19th century. During the 20th century, these lists were in most cases replaced by a provision that crimes of certain gravity were extraditable, subject to the double criminality principle, meaning that the crimes needed to be classified as such crimes in both states.

For a variety of reasons discussed later, states have wished to protect political offenders from extradition. As extradition is a highly political matter, the extradition of political offenders is even more so. According to Christopher H. Pyle, "The extradition of political fugitives has more to do with politics than with justice." ${ }^{302}$ For the purpose of offering protection, the political offence exemption to extradition was created in the 1800 s. The POE is a reservation in extradition treaties which allows states to deny the extradition of an offender should their actions be considered to be of a political character. ${ }^{303}$ As the reservation provides a right to refuse extradition, but not a duty to renounce it, it does not guarantee the immunity of political offenders from extradition. ${ }^{304}$

As discussed earlier, sometimes extradition can take place even when no extradition treaty between the requesting and requested state exists. The decision whether to extradite always lies with the requested country, subject to binding treaty provisions. The requested state can thus choose to extradite a political offender to a state with which it has an existing extradition treaty that contains the POE, or any offender to a state with which it does not have a treaty.

The political offence exception has been incorporated into most extradition treaties since the mid-19th century and it is one of the first international legal doctrines that aimed at protecting the individual. ${ }^{305}$ Many regard it as a fundamental democratic principle ${ }^{306}$ and some as a legally binding principle. Others regard it as a political axiom of liberal democracies. Geoffrey Gilbert has argued

300 See Held, 1995, 74-78.

301 Deere, 1933, 249; Oppenheim, Jennings and Watts, 1992, 951.

302 Pyle, 2001, ix.

303 Van den Wijngaert, 1980, 1.

304 Gold, 1970, 192; Van den Wijngaert, 1980, 45, 133.

305 On a wider scale, this tendency only blossomed after World War II. See e.g. Van den Wijngaert, 1980, 37.

306 Van den Wijngaert, 1980, 133. 
that the POE might have become a part of the 'folklaw' of the political tradition of Western democracies. ${ }^{307}$

Regardless of the prevalence of the POE, its scope is typically not defined in treaties. As explained, in the past, extradition treaties contained a list of extraditable offences. Because these lists did not incorporate pure political crimes such as treason, the exception was first and foremost applicable to relative or mixed political offences. However, as discussed, there is no general consensus over which acts constitute relative political offences. Nowadays, treaties growingly contain clauses that define extraditable offences without using the list system, but rather by setting a minimum penalty for the offence to be extraditable. As many crimes, such as treason, come with severe penalties and are punishable in most states, it is possible to consider such crimes extraditable, unless protected by the POE. Additionally, many crimes that could in theory be classified as political offences have been depoliticised so that they are not included in the exception. The political offence exception and the depoliticisation of specific crimes, including terrorism, are discussed and analysed in detail throughout this book.

As there is no generally accepted definition of political crime, states are able to use the POE as they please. However, as Lieberman has pointed out, the states' own interests should protect the exception from over usage. If the exception is invoked too often, it is less likely that the requested state will accept an extradition request. Additionally, the overuse of the principle may disrupt the political order and stability, which in turn can diminish the whole extradition framework and criminal prosecutions. ${ }^{308}$

Throughout times, the political offence exception has caused debates and diplomatic collisions, especially because it has been used to protect not only non-violent offenders but also perpetrators of atrocious acts of wanton violence. Arguably, the protection of such criminals was never the purpose of the exception. ${ }^{309}$

The most important changes to extradition treaties relate to the rise of international terrorism in the 1960s and 1970s. The European Convention on the Suppression of Terrorism (ECST) of 1977 excluded terrorists from the protection of the POE. Since this treaty, both US and European extradition treaties have slowly limited the POE so that it would no longer protect violent offenders. The question remains whether the chosen limitations have been able to protect the spirit of the POE whilst excluding a wide variety of offences from the protection.

\subsubsection{Who is a political offender? Four tests}

In 1909, Frederic Coudert stated:

If this be the law and the United States is forced to refuse extradition for acts which are abhorrent to rudimentary notions of morality, is it not time

307 Gilbert, 1998, 280.

308 Lieberman, 2007, 183.

309 See especially Chapter 3, Section 3.1.4, for the discussion on the purposes of the exemption. 
that some change be made in the law? Are we to be slaves to mere legalism, or will we try to fulfil the real purpose of extradition, viz.: remove from this country those persons whose brutal and hideous conduct, whatever its ultimate causes may have been, make them dangerous and unfit members of our society?[...] Is legal language so feeble that we can find no rule to differentiate between acts which excite our severest condemnation and those which may be well admired? ${ }^{310}$

The coming into practice of the political offence exception and its later use has been dependent on the definition of 'political crime.' For this purpose, offences were categorically divided into relative and pure political offences, as discussed earlier. Different nations included different acts in the scope of the exception. Applying the POE to pure political offences, such as treason or sedition, has been straightforward in state practice. However, when faced with a mixed or relative political crime, the application of the exemption has proved difficult, as the requested state has to evaluate and balance an act that violates both state and private interests. ${ }^{311}$

As the judiciary has been faced with cases where an offender sought has claimed that the offence in question was of political nature, it has been forced to evaluate and delineate the POE. For this purpose, different courts have created tests that assist in determining who is protected by the exemption. ${ }^{312}$ There are four tests that typically have been used for the purpose of deciding whether the POE can be applied. These are the political incidence test, the predominance test, the political motivation test, the injured rights theory, and as a fifth test, the mixed approach which combines all four. In the following, the emergence and application of these four theories are presented. The aim is to provide a view on the difficulties in applying the POE, which has had implications on the decisions to delineate or even demolish it.

\subsubsection{The UK: the political incidence test}

As described, the United Kingdom and the United States never had specific laws that concerned political crime due to the prevalence of the doctrine of legalism ${ }^{313}$ within English history and philosophy. As the state provided for the basic freedoms of its citizens, it was considered a moral duty for the citizen to obey the law. In fact, in the United States, political crime was traditionally viewed as more immoral than an ordinary crime. This is because the political criminal challenges the whole society, the guarantor of liberties. ${ }^{314}$

310 Coudert, 1909, 141-142.

311 Sofaer, 1986, 126.

312 This chapter presents these tests and some of the most notable cases summarily. For more detailed information, see e.g. Van den Wijngaert, 1980, 111-120.

313 Legalism, as defined by Shklar, "is the ethical attitude that holds moral conduct to be a matter of rule following, and moral relationships to consist of duties and rights determined by rules." Shklar, 1986, 1.

314 Ingraham and Tokoro, 1969, 160-161. 
The lack of such a concept in national legislation has not prevented these countries from accepting the political offence exemption to extradition in their bilateral extradition treaties and applying a rather liberal view on political offenders from other countries.

The UK has since the late 1800s applied the so-called political incidence test. This test was gradually developed in UK case law. ${ }^{315}$ It first limited the POE to deeds committed 'in the course of' and 'in furtherance of' a political disturbance attempting to change either the government or its approach. This interpretation was developed in the 1891 case In re Castioni. ${ }^{316}$

In the Castioni case, Swiss officials made a request to England for the extradition of Angelo Castioni who had murdered Luigi Rossi, a public official, during an armed popular uprising. As this deed, in addition to furthering political goals, was incidental to and formed a part of wider political disturbances, and did not relate to private grudges, the conditions of the incidence test were filled. ${ }^{317}$

Hannay has suggested that the court in the Castioni case relied on "some notion of 'respectable' political upheavals such as the War of the Roses or the American or English civil wars in which gallant men in dashing uniforms met fair and square on the field of battle." ${ }^{318} \mathrm{He}$ has also argued that "the brutality of modern terrorism has rendered the Castioni test obsolete and the complexity of modern political struggles has rendered it unworkable." 319

The application of the political incidence test by the United Kingdom was, however, not consistent. In the Kolczynski case ${ }^{320}$ in 1954, Poland requested the extradition of Kolczynski and six other seamen who had revolted in British waters. The revolters brought their ship to an English port to seek political asylum. They expressed their concern about their political discussions being overheard on board and claimed that they would face trial should they be returned to Poland. There was no political uprising in Poland, but the British court deemed that it should be no crime for one to leave his country, ${ }^{321}$ even if the extradition treaty between Poland and the UK included revolt in its list of extraditable crimes. ${ }^{322}$

L.C. Green argued in 1962 that the Kolczynski case both preserved an appearance of continuity with earlier practice, as well as gave the courts

315 See in more detail the development of the POE in British law Pyle, 2001, 84-95.

316 In re Castioni [1891] 1 Q.B. 149. See e.g. Gilbert, 1985, 697; Gilbert, 1991, 121; Pyle, 2001, 93-95.

317 See e.g. García-Mora, 1956, 79; Green, 1962, 330; Bassiouni, 1969, 250; Epps, 1979, 62; Van den Wijngaert, 1980, 111; Schlaefer, 1981, 625; Gilmore, 1992, 705; Noone and Alexander, 1997, 62-64, for details on the decision.

318 Hannay, 1980, 401.

319 Hannay, 1980, 411.

320 Regina v. Governor of Brixton Prison, Ex parte Kolczynski, [1955] 2 Q.B. 540.

321 See e.g. Epps, 1979, 66-68; Van den Wijngaert, 1980, 112; Schlaefer, 1981, 626-627; Banoff and Pyle, 1984, 186; Gilmore, 1992, 709; Noone and Alexander, 1997, 66-68; and Stanbrook and Stanbrook, 2000, 72, for details on the decision.

322 Article 3 (29) Extradition treaty between His Majesty, in respect of the United Kingdom, and the President of the Polish Republic, 11 January 1932. 
flexibility. It made it possible for the courts to decide to protect a certain individual who might have faced political persecution if returned, rather than only refuse the extradition of an offender who had committed a particular type of offence. ${ }^{323}$ The decision was based on the application of the discrimination clause in the UK-Poland treaty, which allowed for the request of extradition to be denied "if he proves that the requisition for his surrender has, in fact, been made with a view to try or punish him for a crime or offence of a political character." ${ }^{24}$ Valerie Epps has pointed out that Kolczynski was one of the cases where it was clear that the fugitive's political views and the fact that Poland was a Communist state affected the outcome of the extradition request: a fugitive with acceptable political views was more likely to receive protection under the POE. ${ }^{325}$

Nowadays, for the United Kingdom to deny extradition for a political offender, the political offence committed does no longer need to be in connection with a specific political uprising. However, the person whose extradition is sought needs to be in political opposition with the requesting state. ${ }^{326}$ These criteria emerged in the Cheng case, where the crime the fugitive was requested for was directed against Taiwan, whereas the requesting state was the US. In this case, the British court allowed extradition for a crime that was undoubtedly of political motivation. ${ }^{327}$

\subsubsection{The US application of the incidence test: In re Ezeta 1894}

In its early decisions concerning the applicability of the POE, the United States closely followed the United Kingdom. However, unlike the United Kingdom, the US courts did not require a clear link between the crime itself and the political goal it was committed for.

The United States has a history of treating political offenders leniently. In the late 1800s and early 1900s, most political offenders earned refuge, even when the conditions of their crimes were not tightly connected with political activities. Further, also acts against private individuals, not only political persons, could qualify. ${ }^{328}$

323 Green, 1962, 331.

324 Article 7, Extradition treaty between His Majesty, in respect of the United Kingdom, and the President of the Polish Republic, 11 January 1932.

325 Epps, 1979, 68. Similarly, Gilbert has called the cases where the courts departed from the incidence test when fugitives from Communist countries were in question, "a small 'hiccup" in the systematic application of the POE. Gilbert, 1991, 121.

326 DeFabo, 2012, 81.

327 Cheng v. Governor of Pentonville [1973] 2 A Il E.R. 204, 209. See in more detail e.g. Epps, 1979, 67; Carbonneau, 1980, 280; Banoff and Pyle, 1984, 188; Noone and Alexander, 1997, 70-73; Sambei, Du Plessis and Polaine, 2009, 428-430.

328 Clark, 1909, 120. See also e.g. Deere, 1933, 268; Evans, 1969, 204; Stanbrook and Stanbrook, 2000, vii-viii; Pyle, 2001, 115. 
In most cases where a fugitive sought the protection of the POE, US courts required that there must be a revolutionary movement in the demanding country and that the fugitive be a member of this movement. The crime itself needed to be committed "in the course of, and as a part of, the political activities of that party to which he belonged." The extent or prospect of success of the uprising in question was not important. The courts did not assess the "wisdom of the act in furthering the asserted political objective, the motive of the accused, nor the organisation or hierarchy of the uprising group." 329 Neither did they investigate the fairness of the requesting system or the basis of the extradition. This so-called rule of non-inquiry permitted the judges to refrain from making political assessments, but at the same time "This deliberative unrealism would contrast sharply with the traditional scepticism regarding the capacity of foreign regimes to match American standards of justice." 330

Traditionally, the US, for instance, had a strong dedication to remaining neutral when it came to the morality of certain acts or their purposes. As Secretary Root explained to the Russian Ambassador who had pushed the US to the adoption of the Swiss proportionality test in 1909 (discussed later): "However much the Government of the United States may deplore or condemn acts of violence done in the commission of acts bearing a political purpose, however unnecessary or unjustified they may be considered, if those acts were, in fact, done in the execution of such a purpose, there is no right to issue a warrant of extradition therefor." 331

The US position was first developed in 1894 in the In re Ezeta case, ${ }^{332}$ in which the court's ruling was based on the logic of the Castioni case. In this ruling, the court interpreted that any crime committed "in the course of" or "in furtherance of" a political disturbance, civil war or insurrection, could be considered of a political character. ${ }^{333}$

In the case, General Antonio Ezeta, the former president of the Republic of Salvador (now El Salvador), and four of his commanders and staff officers were wanted for crimes, including executions, they allegedly had committed to attempting to suppress a coup d'état which took place in 1894. Ezeta was also accused of robbing a bank and using the stolen money for his soldiers' wages. The court saw that as the crimes were connected with the armed conflict, they were political in nature and not extraditable. As in many other US extradition treaties, Article 3 of the US-Salvador extradition treaty from 1874 provided that

329 Lieberman, 2007, 189.

330 Pyle, 2001, 118. See more on the rule of non-inquiry e.g. Dugard and Van den Wijngaert, 1998, 189-191; and Blakesley, 2002, 605-609.

331 Cited in Pyle, 2001, 114.

332 In re Ezeta. In re Bolanos, In re Colocho. In re Cienfuegos. In re Bustamante, 62 F. 972 (District Court, N.D. CA 1894).

333 See e.g. Garcia-Mora, 1962, 1244-1245; Epps, 1979, 68-69; Hannay, 1980, 391-392; Lubet, 1982, 262; Gilbert, 1985, 700; Banoff and Pyle, 1984, 183-184; Pyle, 2001, 109110; Piemonte, 2013, 623, for a discussion on the case. 
"The provisions of this treaty shall not apply to any crime or offence of a political character." 334

The court did not examine the goals or tactics used. The two criteria based on which the District Court made its decision were, first, that an uprising, revolution or rebellion against an existing government had to be occurring concurrently with the commission of the crime. Second, the crime had to be committed in order to assist this rebellion. The District Court judge justified this by arguing that "I have no authority, in this examination, to determine what acts are with the rules of civilised warfare, and what are not. War, at best, is barbarous and hence it is said that "the law is silent during war." 335 As such, as feared by the Castioni court, the Ezeta decision made it possible to consider almost any crime as political. ${ }^{336}$ The decision also showed that the protection by the POE was not limited to revolutionaries against autocracies. ${ }^{337}$

Another case where the political incidence test protected an offender from extradition from the US for questionable reasons was that of Lynchehaun in 1903. The Catholic Irishman James Lynchehaun was requested by the British government for brutally assaulting and murdering his Protestant landlady. At first, it seemed that Lynchehaun's attack was motivated by personal grudge over his eviction. Upon his arrival to the US, Lynchehaun, however, claimed the offence had been of political nature and the attack was part of an organisational decision by the Irish Republican Brotherhood to fight for the cause of oppressed tenants. In consequence, the American court saw the crime as "incidental to a popular movement to overthrow landlordism in Ireland" and thus unextraditable. ${ }^{338}$

Similarly to the Ezeta case, the Ornelas case ${ }^{339}$ from 1896 followed the logic of the Castioni ruling. In this case, Mexico sought the extradition of three men who were wanted for murder, arson, robbery and kidnapping, allegedly committed during an attack on a local village. Unlike the District Court had done, the Supreme Court finally granted extradition. It took into consideration the nature of the crimes, the way in which they had been committed and the persons of the victims. As there were no Mexican government forces near the village at the time of the attack and the accused had fled the scene with stolen items, the court deduced that the crimes were not incidental to a political occurrence. ${ }^{340}$

334 The contents of the treaty is cited in In re Ezeta. In re Bolanos, In re Colocho. In re Cienfuegos. In re Bustamante, 62 F. 972 (District Court, N.D. CA 1894).

335 In re Ezeta. In re Bolanos, In re Colocho. In re Cienfuegos. In re Bustamante, 62 F. 972 (District Court, N.D. CA 1894). Also cited in Lieberman, 2007, 191.

336 Gilbert, 1991, 125; Gilbert, 1998, 227.

337 Pyle, 2001, 109-110.

338 See in more detail García-Mora, 1956, 79; McElrath, 2000, 11; Pyle, 2001, 116; and The Irish Independent, "Hero or villain? The gruesome tale of the 'real' Playboy of the Western World," 6 May 2012.

339 Ornelas v. Ruiz 161 U.S. 502, 510-512 (1896).

340 See in more detail e.g. Garcia-Mora, 1962, 1245-1247; Epps, 1979, 69-70; Hannay, 1980, 392; Gilbert, 1991, 125; Gilbert, 1998, 229; Piemonte, 2013, 623-624. 


\section{2}

Concepts employed

In the light of the Ornelas case, it is interesting to note that the extradition treaty between the US and Mexico that was renewed a few years after the decision in 1899 had been the only treaty in US history to include only purely political crimes into the scope of the POE. ${ }^{341}$ It is possible that the case affected the decision-making of the drafters of the treaty, and that their wish was to prevent the possibility of violent offenders escaping extradition, even if in the Ornelas case the fugitive did not manage to escape justice.

Extradition law in the United States does not contain the so-called discrimination clause, a provision that extradition can be banned for the fear that the person requested might face persecution if returned. The clause has also been rarely used in US extradition treaties. ${ }^{342}$ The only question courts decide upon is whether the person accused is wanted for a political crime. ${ }^{343}$ Thus, one of the main reasons behind the creation of the POE, the possibility of the suspect receiving biased treatment by the requesting state's courts, has never been discussed in applying the incidence test. ${ }^{344}$

\subsubsection{Evaluating the incidence test}

As the political incidence test concentrates on evaluating the existence of a political disturbance instead of the motives of the perpetrator, some have considered it as the most objective way to assess whether the POE is applicable. ${ }^{345}$ It excludes deeds by individuals and groups with no popular support. As a result, groups such as the RAF in Germany or the Direct Action in France could not have received the protection of the POE even if their acts clearly were politically motivated. ${ }^{346}$

However, even if seemingly simple, applying the incidence test has not been straightforward, as it has remained unclear how the concepts of political conflict or incidence are defined. ${ }^{347}$ Additionally, while judges in US courts have typically concentrated on the target of the action, which has sometimes been seen as a more 'objective' approach, it still remains unclear what kind of a target could turn a 'common' crime into a 'political' crime. ${ }^{348}$ Further, when the political incidence test is applied, the seriousness of the acts is not considered. This approach has been criticised, for instance, by Christine van den Wijngaert, who has argued that the gravity of the crimes should be used as the main criteria for establishing whether the POE is applicable. ${ }^{349}$

341 Article 3, United States-Mexico Extradition Treaty, 22 February 1899. See "Political Offence," 1909.

342 See Section 2.2.2.

343 Banoff and Pyle, 1984, 170.

344 Banoff and Pyle, 1984, 182.

345 Van den Wijngaert, 1980, 111; Sapiro, 1986, 671.

346 Pyle, 1988, 187.

347 Sapiro, 1986, 672; Lieberman, 2007, 188-189.

348 Sapiro, 1986, 675-676.

349 Van den Wijngaert, 1980, 117-118. 
The incidence test has received criticism for being simultaneously overinclusive and underinclusive. The underinclusiveness of the incidence test is visible when no 'recognised' rebellion exists. In such a case, those attacking the government cannot be protected by the POE. ${ }^{350}$ Then again, the test is sometimes overinclusive, as it can be used to protect any act that coincides with political turbulence or assists a rebellion in any way. ${ }^{351}$ Steven Lubet argued in 1982 that bringing the Castioni test to its "insane but logical end," might end up protecting terrorists from extradition. This point of view was based on the British experience. In Britain, courts had ended up nearly abandoning the test for this reason. ${ }^{352}$ In the 1980s, it became clear that Lubet's prediction had been correct. The details of this will be discussed in Chapter 4, Section 4.2.

The problematic nature of the direct application of the incidence test first became clear when Yugoslavia sought for the extradition of Artukovic, ${ }^{353}$ an exMinister of the Interior of a pro-Hitler government in Croatia during WWII. Artukovic was responsible for thousands of killings, which amounted to war crimes and genocide. The United States court deciding the case considered the crimes political, and thus non-extraditable. ${ }^{354}$ According to Christopher H. Pyle, "The decision to grant Artukovic benefit of the political offence exception has been called 'one of the most roundly criticised cases in the history of American extradition jurisprudence.' More than any other decision, it caused the political offence exception to lose its reputation as a shield for liberal revolutionaries and come to be seen as a 'legal loophole' benefiting every sort of tyrant its inventors most despised." ${ }^{355}$ It remains unclear whether the strict interpretation of the incidence test was a purely judicial opinion, or if it was affected by wider political considerations, namely the fact that the request was made by a Communist country. ${ }^{356}$

Similarly, the Ramos $v$. Diaz ${ }^{357}$ case of 1959 has been suspected to have been influenced by anti-Communism. The case involved two Cubans who had been convicted of murder by the Castro government. The pair escaped from prison

350 Kulman, 1986, 767.

351 García-Mora, 1956, 79; Garcia-Mora, 1962, 1246-1247; Lubet, 1982, 263; Kulman, $1986,766$.

352 Lubet, 1982, 263-264.

353247 F.2d 198 (9th Cir. 1957), vacated and remanded, 355 U.S. 393 (1958), surrender denied on remand sub nom. United States v. Artukovic, 170 F. Supp. 383 (S.D. Cal. 1959). See e.g. Garcia-Mora, 1962, 1247.

354 See e.g. Bassiouni, 1973, 36; Epps, 1979, 71-72; Van den Wijngaert, 1980, 118-119; Hannay, 1980, 392; Schalefer, 1981, 627-629; Lubet, 1982, 263; Banoff and Pyle, 1984, 184; Sofaer, 1986, 130; and Pyle, 2001, 132-139, for details on the decision. It has to be noted that the US only ratified the Genocide Convention of 1948 in 1988. Convention on the Prevention and Punishment of the Crime of Genocide, UNTS No 1021, 9 December 1948.

355 Pyle, 2001, 138-139.

356 Hannay, 1980, 392.

357 Ramos v. Diaz, 179 F. Supp. 459 (S.D. Fla. 1959). 


\section{Concepts employed}

and fled to the United States. Their claim was that the murder had been committed as part of revolutionary activities. The court was of the opinion that the Cuban government had not shown that the crimes were non-political in nature and for this reason denied extradition. ${ }^{358}$

In comparison, in the case of Gonzales ${ }^{359}$ in 1963, extradition was granted. The defendant allegedly took part in the torturing and killing of two prisoners while working in a military or quasi-military capacity for the dictatorial Trujillo regime in the Dominican Republic. The court held that the offences were not political in nature. Valerie Epps has pointed to the political relevance of this decision; the regime requesting for the extradition was the new regime, not the Trujillo dictatorship which the US disfavoured. ${ }^{360}$ In a footnote, Judge Tyler pointed to the case of Kolczynski and "the history of the political offence exception in Anglo-American law" which "arguably indicates that the political offence exception legitimately can be applied with greater liberality where the demanding state is a totalitarian regime seeking the extradition of one who has opposed that regime in the cause of freedom." ${ }^{361}$

In the case of Mylonas in $1960,{ }^{362}$ the Greek request for the extradition of an accused embezzler was denied, partly against the rule of non-inquiry typically applied by US courts. The court noted that the accused Mylonas had been an active anti-Communist and would not necessarily get a fair trial in the hands of the predominantly Communist municipal government. ${ }^{363}$ This stance was taken notwithstanding the lack of a discrimination clause in the US-Greece extradition treaty. ${ }^{364}$

Epps has compared the Mylonas case to the similar case of Jimenez $v$. Aristeguieta where extradition was permitted. ${ }^{365}$ Jimenez was the former president of Venezuela. He had gained power through a military coup d'état but was later overthrown. The new regime sought for his extradition from the US based on charges of embezzlement and murder. Evidence for the embezzlement charge was found to be sufficient, and Jimenez was extradited regardless of claiming that the offences had been political. According to Epps, the difference between the cases of Mylonas and Jimenez "appears to be that Jimenez had been part of a disfavoured regime, and the United States had no wish to offend the newly established Venezuelan government."366

358 See e.g. Epps, 1979, 73; Hannay, 1980, 397-396.

359 In re Gonzalez, 217 F. Supp. 717 (S.D.N.Y. 1963).

360 Epps, 1979, 73.

361 In re Gonzalez, 217 F. Supp. 717 (S.D.N.Y. 1963). Also cited in Epps, 1979, 73.

362 In re Mylonas, 187 F. Supp. 716 (N.D. Ala. 1960).

363 See e.g. Epps, 1979, 73-74; Banoff and Pyle, 1984, 190.

364 Greece International Extradition Treaty with the United States, 6 May 1931.

365 Aristeguieta v. Jimenez, 274 F.2d 206 (5th Cir. 1960).

366 Epps, 1979, 74. 
Nowadays, the US test categorically excludes certain crimes from the scope of the POE for being inefficient as a means to achieve a political objective. ${ }^{367}$ According to Christopher H. Pyle:

In retrospect, it is curious that more was not done earlier, in both the UK and the US, to exclude wanton crimes from the scope of the political offence exception. But in Meunier, Ezeta, the Mexican border raid cases, the Russian death-squad cases, and Lynchehaun, the terroristic nature of the crimes was downplayed, as was the requirement of a full-scale, popular revolution. So long as the 'movement' did not export its killing to Western Europe or the US, its atrocities and futility could be tolerated by an America that was still sufficiently uninvolved in international relations to be able to see the rebels (or their adversaries) for what they were. ${ }^{368}$

\subsubsection{The French injured rights theory}

Where the United States' take on the political offence exemption has been an encompassing one, France has taken a narrow stance on the matter. In the case of In re Giovanni Gatti ${ }^{369}$ in 1947, the Grenoble Court of Appeals outlined that only crimes directly injuring the state, causing no harm to individuals, could be included within the scope of the exemption. Thus only a few crimes could fall into this category: espionage, sedition or treason. ${ }^{370}$ It is noteworthy that these are crimes that were not typically listed as extraditable offences in extradition treaties, meaning that the POE in the French treaties was essentially void.

In the Gatti case, the fugitive, Giovanni Gatti, had attempted to kill a member of a Communist cell. San Marino sought his extradition, but Gatti pleaded that he could not be extradited as his offence was political in nature. ${ }^{371}$ The court, however, reasoned: "The fact that the reasons of sentiment which prompted the offender to commit the offence belong to the realm of politics does not itself create a political offence. The offence does not derive its political character from the motive of the offender but from the nature of the rights it injures." 372 "The reasons on which nonextradition is based do not permit the taking into account of mere motives for the purpose of attributing to a common crime the character of a political offence." ${ }^{373}$ Further: "In brief, what distinguishes the political

367 Lieberman, 2007, 189.

368 Pyle, 2001, 117.

369 Gatti (1947) Ann. Dig. 145, 146 (Case no. 70). Cited in Garcia-Mora, 1962, 1236; Green, 1962, 335; and Gilbert, 1985, 700 .

370 García-Mora, 1956, 77; Garcia-Mora, 1962, 1236, 1249-1250; Green, 1962, 335-336; Carbonneau, 1980, 276; Gilbert, 1985, 700; Gilbert, 1991, 127.

371 García-Mora, 1956, 77; Garcia-Mora, 1962, 1236, 1249-1250; Green, 1962, 335-336; Carbonneau, 1980, 276; Gilbert, 1985, 700.

372 Garcia-Mora, 1962, 1249-1250. See also e.g. Hannay, 1980, 391.

373 Cited in Garcia-Mora, 1962, 1250. 
crime from the common crime is the fact that the former only affects the political organisation of the state, the proper rights of the state, while the latter exclusively affects rights other than those of the state." 374

The French take has been labelled as the 'injured rights theory ${ }^{375}$ or the objective test $\mathrm{t}^{376}$ and it limits the scope of political offences to crimes that target the political organisation of the state, regardless of the political motivation of the offender or lack thereof. ${ }^{377}$ The political nature of the crime is thus not defined by the motive of the offender, but rather by the target and the means used. As a result, relative political offences containing elements of common crime were excluded from the French interpretation. ${ }^{378}$

The French model received criticism, as the protection of the political offence exemption was denied to those offenders whose target was other than political institutions. At the same time, common criminals with purely private motives using the state as a target can be protected by the exemption, which originally aims at protecting political offenders. ${ }^{379}$

\subsubsection{The predominance test}

All of the aforementioned approaches used to determine whether a fugitive can be protected by the political offence exemption have received criticism. As they all ignore the outcome of the extradition, one of the main reasons for which the exemption was created in the first place was forgotten: the worry about the treatment the person might receive should they be extradited. In addition, these approaches also attempt to examine the consequences or the motivation behind the acts. Such considerations do not usually belong to criminal law, except when the motivation of the person is used to determine the guilt in concreto or the penalty (aggravating or mitigating circumstances). These deliberations do not, however, affect the nature of the crime in question. ${ }^{380}$

The Swiss approach, the so-called predominance test, or political motivation test, applied also for instance by the Netherlands, ${ }^{381}$ tries to avoid the aforementioned issues and has become the most widely accepted amongst academics. ${ }^{382}$ In the 19th century, Switzerland served as a safe haven for political refugees who were using its soil as a base of their revolutionary activities. Several extradition requests to capture these fugitives failed, and as a result, other countries criticised

374 Cited in Garcia-Mora, 1962, 1236.

375 Blakesley, 1986, 113.

376 Garcia-Mora, 1962, 1249.

377 Garcia-Mora, 1962, 1249; Bassiouni, 1969, 250.

378 Green, 1962, 335; Bassiouni, 1969, 251; Gilbert, 1985, 700.

379 DeFabo, 2012, 79; Garcia-Mora, 1962, 1251.

380 See e.g. Van den Wijngaert, 1980, 126.

381 Van den Wijngaert, 1980, 130; Gilbert, 1998, 303.

382 See e.g. Garcia-Mora, 1962, 1256; Gilbert, 1991, 128; Gilbert, 1998, 234. 
Switzerland for the protection of rebels. In 1892, Switzerland enacted an extradition law which incorporated the predominance test. ${ }^{383}$

In the predominance test, first laid out in the V.P. Wassilieff case, the relationship between the offence and the end it seeks are balanced. In the Wassilieff case, Russia sought the extradition of its national wanted for the murder of a chief of police. Extradition was granted, as, to the surprise of other states, the Swiss court considered the act as predominantly a common crime, as it did not pursue the realisation of a purely political offence and the accused would have had other, non-violent means for pursuing his political goal. ${ }^{384}$ Thus the Swiss test tried to evaluate whether the end sought could be efficiently be achieved through the use of the illegal means in question. As explained in the case of In re Nappi, if the means were seen as efficient in pursuing the political goal, the political element could be seen to prevail. ${ }^{385}$ This meant a change in the traditional policy of the Swiss to protect political offenders. ${ }^{386}$

Based on the proportionality test, Switzerland also granted the extradition of Kaphengst in 1930. In this case, a German national was accused of terroristic bombings in Prussia, allegedly political in motive. ${ }^{387}$ Similarly, Della Savia, ${ }^{388}$ who was a member of an anarchist-nihilist organisation called 22 October, was extradited. The Swiss court held that the acts did not have a clear relation to any political struggle. The court pointed out that the accused might have achieved his political end by legal means and was not forced to resort to atrocious methods. Interestingly, Savia was caught with the assistance of Interpol, which was dedicated to keeping out of political matters. ${ }^{389}$

The predominance test was further developed in In re Ockert. ${ }^{390}$ The test now measured also proportionality, meaning that the means used needed to be in proportion to the end sought. In the In re Kavic case, ${ }^{391}$ members of the crew of a passenger plane who were Yugoslav nationals intimidated other crew members, redirected the plane to Switzerland and sought asylum. The Swiss court came to the same conclusion as its English counterpart in a similar case, Ex parte

383 See e.g. Deere, 1933, 256-257; García-Mora, 1956, 79-80; Garcia-Mora, 1962, 1252; Green, 1962, 333.

384 [1909] Foreign Relations. U.S. 519 (1914). See e.g. García-Mora, 1956, 79.

385 In re Nappi, 19 LL.R. 375 (Fed. Trib., Switz., 1952). Cited in Gilbert, 1991, 128; Gilbert, $1998,234$.

386 See Jensen, 2014, 332 .

387 Garcia-Mora, 1962, 1254.

388 Della Savia contro Ministero pubblico della Confederazione, BGE 95 I 462 (1969). See also Deere, 1933, 259; García-Mora, 1956, 87; Garcia-Mora, 1962, 1254; and Van den Wijngaert, 1980, 127-128, for details on this case.

389 See in more detail Chapter 4, Section 4.1.4.

390 In re Ockert, Bundesgericht, Oct. 20, 1933, 59(1.) Entscheidungen des Schweizerischen Bundesgerichtes 136, 137, [1933-34] Ann. Dig. 369, 370 (No. 157) (Swit.).

391 In re Kavic, [1952] Int'l L. Rep. 371 (No. 80) (Swit.) 
Kolczynski: ${ }^{392}$ the Federal Tribunal invoked the predominance theory and denied extradition. It concluded that the ideals connected with the escape from a totalitarian regime and the link between the deed and its aim were strong enough to justify the injury to private property and other, less serious crimes. ${ }^{393}$

The protection of fugitives from totalitarian states was of wider concern in the decades following the Second World War. For instance, in 1961, Otto Kirchheimer wrote: "More and more it is considered a noble service to shield nonpolitical fugitives whom totalitarianism threatens with a politically motivated prosecution." ${ }^{394}$ At this stage, the liberal roots of the POE were clearly visible.

Switzerland applied the tightest criteria to violent crimes in evaluating whether the political element could outweigh the common element of the crime. The key was that violence had to be the only means to achieve the sought political end. Hence, the Swiss test seems to exclude all terrorism from the scope of the political offence exemption. ${ }^{395}$ However, it does not categorically deny a political character to certain offences, as opposed to for instance the attentat clause. ${ }^{396}$

The Swiss proportionality test would seem to best serve the purpose of protecting 'true' revolutionaries and excluding terrorists. In addition to many scholars, the application of the predominance test to the POE has received support from Irish ${ }^{397}$ and Dutch courts, ${ }^{398}$ some extradition treaties and the national legislation of some countries. ${ }^{399}$ The UN Convention Relating to the Status of Refugees of 1951 also refers to a similar criterion when assessing the nature of the crimes committed by a refugee. The Refugee Convention also protects political

392 Regina v. Governor of Brixton Prison, Ex parte Kolczynski [1955] I Q.B. 540. See Chapter 3, Section 3.2.1.

393 Garcia-Mora, 1962, 1254-1255.

394 Kirchheimer, 1961, 380.

395 See e.g. Deere, 1933, 258; García-Mora, 1956, 77; Garcia-Mora, 1962, 1254; Bassiouni, 1969, 252; Van den Wijngaert, 1980, 126-129; Gilbert, 1985, 700-702; Gilbert, 1991, 129; Gilbert, 1998, 236, 305; Stanbrook and Stanbrook, 2000, 77. However, Deere has suggested that even anarchist offences have fallen into the category of political offences based on the application of the predominance test. Deere, 1933, 257.

396 Deere, 1933, 253. See Chapter 3, Section 3.1.3, for a discussion on the attentat clause.

397 According to Gilbert, for the Irish courts, the turning point was the McGlinchey p. Wren decision of 1982. Gilbert, 1991, 148.

398 Gilbert, 1991, 150.

399 García-Mora has pointed out that "The convention between Poland and Czechoslovakia which provides that extradition will not be granted 'if the offence is political or is connected with a political offence, unless the characteristic of an offence under ordinary law predominates.' Convention Between Poland and Czechoslovakia, 21 January 1949, Article 60, (b), 31 U.N.T.S. 300. See also Treaty of Extradition with Brazil, 13 January 1961, Article V, para. 6(a), 44 Dept State Bull. 166 (1961); Extradition Treaty Between Brazil and Bolivia, 25 February 1938, Article III, $\$ 1$, 54 U.N.T.S. 348; Convention between Finland and Sweden, 29 November 1923, Article 2, para. 1, 23 L.N.T.S. 42; Convention between Latvia and Lithuania, 12 July 1921, Article 2, 25 L.N.T.S. 313; Additional Protocol to the Extradition Treaty between Argentina and Italy, 9 June 1904, Article IV, [1905] Foreign Relations. U.S. 33 (1906). Garcia-Mora, 1962, 1255. 
criminals and determines whether an offence is considered political by looking at "whether it has been committed out of genuine political motives and not merely for personal reasons or gain." Additionally, a "close and direct causal link between the crime committed and its alleged political purpose and object." Finally, "The political element of the offence should also outweigh its commonlaw character. This would not be the case if the acts committed are grossly out of proportion to the alleged objective." Further, the atrocious nature of the crimes may also affect whether the crime is considered political. ${ }^{400}$

However, as Geoffrey Gilbert has pointed out, the test is not perfect for modern requirements: "To use it [the predominance test] is merely to continue applying nineteenth-century standards, drafted to combat the problems of that era in Europe, to twentieth-century circumstances. Moreover, the Swiss interpretation is open to abuse, since it is possible to extradite a fugitive in circumstances where his trial would be prejudiced and partial in the requesting state. ${ }^{401}$ Additionally, also the Swiss test is subjective and dependent on the political views of the requested state. ${ }^{402}$ However, according to Gilbert, the Swiss test is the most suitable for the use of trying to achieve both ends, the promotion of the international public order and the protection of political activism, ${ }^{403}$ as it is simple and universally applicable and preserves judicial discretion. The Swiss test has sometimes also been applied in German and English extradition cases. ${ }^{404}$

\subsection{Conclusion}

This chapter has been an introduction to the key concepts used in this study. It has presented the concepts of 'political crime,' 'terrorism,' 'extradition,' the 'political offence exception to extradition' as well as 'depoliticisation' in a manner that makes it possible to use all of these concepts as subjects of study and tools for analysis in the coming chapters of the book. As shown, none of these concepts is easily definable and one objective of this research is to be involved in the discussion that surrounds the ongoing process of definition.

The aim of this chapter has also been to position my research on the map of existing scholarship, with regard to the use of the key concepts but also with

400 Para 152, Handbook on Procedures and Criteria for Determining Refugee Status under the 1951 Convention and the 1967 Protocol velating to the Status of Refugees. HCR/IP/4/Eng/ REV.1, UNHCR 1979, reedited January 1992.

401 Gilbert, 1991, 130.

402 Gilbert, 1991, 151; Gilbert, 1998, 307.

403 Gilbert, 1991, 131.

404 See e.g. the case of T where the UK extradition court as well as the House of Lords ruled that a bomb attack by Islamists against an airport in Algiers could not, in spite of its political context and motivation, be considered a relative political offence because of the danger posed to innocent bystanders. Tv. Secretary of State for the Home Department [1995] 2 All E.R. 1042, [1994] I W.L.R. 545; Tv. Secretary of State for the Home Department [1996] 2 All E.R. 865. Kälin and Künzli, 2000, 66. 


\section{Concepts employed}

regard to the researchers I engage in a discussion with. As stated, my viewpoint is that of a social scientist engaged in research on a variety of legal issues. My background is visible in the way I look at legal concepts; first and foremost, I understand them as products of their own time and as social constructions.

This viewpoint has given me the possibility to look beyond legal concepts and to frame them in a way that makes their usage more transparent and understandable. I readily accept that for the purposes of applying the law, my considerations might not necessarily be useful, because the more I look into these concepts, the more questions I find unanswered. However, for the purposes of further analysis and research, unanswered questions should prove a fertile ground to build on for others.

The next chapter begins with deepening the understanding of the concept of the political offence exception and offers a historical viewpoint to its development. 


\section{The rise and decline of romantic liberalism \\ From the 1800s to the 1960s}

\subsection{The emergence of the political offence exception in the 1830s}

\subsubsection{Revolution as evolution}

One of the leading historians of our times, Eric Hobsbawm, called the early 19th century (1789-1848) the Age of Revolution. ${ }^{1}$ This period saw an unprecedented amount of political turmoil in Europe and North America, and permanently changed the ideological views on how the world should be run. The Age of Revolution witnessed the rise of nationalism and of new nation states. Emerging nations needed to assert their independence, authority and equality in the new field of political players. One of the key areas where new relationships were established was the field of treaty law, which extradition formed a part of. The idea that the state is limited by the law emerged. The Age of Revolution also witnessed a new take on political offenders, who were now seen as heroes fighting for liberty ${ }^{2}$ instead of traitors opposing the might of the king. This led to the creation of the so-called political offence exception (POE), which protected political criminals from extradition.

The first steps in what later became known as human rights law were taken during this same period. As a distinction from autocratic regimes, the newly established liberal nations set up rights for individuals, the legal safeguards provided by extradition treaties being part of them. Geoffrey Gilbert has described this process as "prevailing philosophies of the eighteenth century shaped the developing extradition law under the unfolding umbrella of international law."

The idea that political offenders were in need of protection emerged in the spirit of a revolutionary atmosphere, combined with emerging liberalist ideas

1 Hobsbawm, 1962.

2 For instance Jules Michelet (1798-1874), professor of history in Paris and a republican, understood the revolutionaries of 1789 as brave, creative and big-hearted. See more on contemporaries' ideas on the revolutionaries of the Age of Revolution. Gemie, 2006, 125-135.

3 Gilbert, 1991, 11. See also Gilbert, 1991, 115; and Gilbert, 1998, 208. 
concerning the rights of the individuals. The unwillingness of nations to surrender political fugitives has been linked with the falling apart of the feudalist system. The feudalist system had been built on a structure of personal obligations. During the Age of Revolution, this structure disintegrated and criminal law became less politicised. Concurrently, major ideological changes took place. Scientific thinking rose with the decline of religious, especially Catholic, impact. The concept of freedom of the press emerged.

This transformation affected the way in which the political criminal was viewed. The rise of the political offence exception was, in Bassiouni's words: “due to the emergence of constitutionalism in the nineteenth century, when the right to freedom and to revolt for freedom became an active reality. Its mottos were set by the eighteenth-century philosophers, who drew largely on the humanism of their predecessors."4

Samuel T. Spear, who authored Law of Extradition, International and InterState in 1885 wrote:

The general sense of civilised nations, especially in modern times, is that merely political offenders are not proper subjects for extradition; and any nation that, having obtained the custody of a fugitive upon other grounds, should put him on trial for a political offence, would be deemed guilty of a gross act of bad faith, and that, too, whether the treaty under which the extradition was secured did or did not contain an express stipulation to the contrary. ${ }^{5}$

The nature of political crimes was now viewed as being progressive and revolutionary or evolutionary, as opposed to the regressive and involutionary nature of ordinary crimes. ${ }^{6}$ Christine van den Wijngaert has talked about "an almost naïve identification of the political offender with the liberal revolutionary" and the exception being "drafted in an atmosphere of romanticism and glorification of political offenders." Political criminals were seen as morally superior, as their motive was to benefit the whole society. ${ }^{8}$ What was not considered was the possibility that they might themselves turn against the liberal legal order. ${ }^{9}$

This study uses the concept of 'romantic liberalism' to describe the sentiments towards revolutionaries in the 1800s. The use of the concept is related to that of Gustavsson who has defined 'romantic liberalism' as "a romantic understanding of why we need a political system with extensive and universal individual liberties." Further, "romantic liberalism gives pride of place to dedicated and authentic

4 Bassiouni, 1969, 244. See also García-Mora, 1956, 74.

5 Spear, 1885,50 .

6 Ferrari, 1920, 311.

7 Van den Wijngaert, 1980, 14.

8 Van den Wijngaert, 1980, 29.

9 Van den Wijngaert, 1980, 14. 
self-expression, not to autonomous self-reflection." ${ }^{10}$ According to her, romantic liberalism "does not stress temperance or agreement in public life. Conflict and strong sentiments are not disturbing elements, but welcome signs of authenticity, vitality and courage." 11 At the core of my definition of romantic liberalism is the understanding of political criminals as heroic figures. The romanticism relates to the idealisation of their goals which were perceived to outweigh and justify also the use of violence in pursuance of self-determination and liberty.

The turn in how the political offenders were viewed reflected a wider change in governance, where European countries one by one moved from autocracy towards liberal democracy. It made it possible to support those who were in the process of trying to overturn despotic regimes and spread the ideal of the democratic state. ${ }^{12}$ It portrayed a revolution in the relationship between the state and the citizen.

A new liberal idea gained ground. According to this idea, the law limits the state. Thus the citizen now had the right to resist, in case the state violated the law or acted in an unjust or immoral way. The right to resist also applied when the state did not serve the society in the best possible way. This principle embraced the idea that crime was a concept which depended on the legitimacy of the government. If the government lost its legitimacy, what it defined as crime could sometimes be seen as justifiable. ${ }^{13} \mathrm{~A}$ similar viewpoint is reflected in the preamble of the Universal Declaration of Human Rights of 1948: "Whereas it is essential, if man is not to be compelled to have recourse, as a last resort, to rebellion against tyranny and oppression, that human rights should be protected by the rule of law." 14

The political criminal, before appraised a public enemy, now became appreciated as someone in search for, and working on the front lines of, progress. Their crime lay in trying to hasten it by illegal and sometimes even violent means. As a result, the political criminal became to be seen as more 'moral' than the ordinary criminal. ${ }^{15}$

The more accepting treatment of political criminals has been especially linked with the political conditions in France. The Declaration of Human Rights created as a result of the French Revolution of 1789 underlined the political rights of men and the right to resist oppression. ${ }^{16}$ In the Jacobean Constitution of 1793, it was declared that the French people "grant asylum to foreigners banished from their countries for the cause of freedom." ${ }^{17}$ As there had been many overthrows

10 Gustavsson, 2014, 63.

11 Gustavsson, 2014, 64.

12 Van den Wijngaert, 1980, 18.

13 Ingraham and Tokoro, 1969, 146.

14 Universal Declaration of Human Rights (UDHR), GA Res 217 A, 10 December 1948.

15 Ferrari, 1920, 311; Kirchheimer, 1961, 33; Ingraham and Tokoro, 1969, 146, 152; Pyle, 2001, 82 .

16 "Le but de toute association politique est la conservation des droits naturels et imprescriptibles de l'homme. Ces droits sont la liberté, la propriété, la sûreté, et la résistance à l'oppression." Article 2, Déclaration des Droits de l'Homme et du Citoyen de 1789.

17 Sofaer, 1986, 126; See also Pyle, 2001, 79-80. 


\section{Rise and decline of romantic liberalism}

of government in France during the 19th century, it became easy to view political criminals as people who had tried to gain power, but just did not have luck in it. ${ }^{18}$ Because only the outcome of the rebellion defined who was the criminal and who the legitimate ruler of a state, rebellion against suppression could be viewed as legitimate. For this reason, political criminals gained a new status where they were considered to deserve protection. ${ }^{19}$

A major turn in the treatment of political crime occurred after the French revolution of 1830. After the revolution, the liberals that rose to power wanted to prohibit governments from using the legal process against their political rivals. ${ }^{20}$ One of the most important cases underlining the need for the protection of the rights of political offenders concerned the extradition of Neapolitan officer Galotti, who was requested for his participation in the 1820 revolution. France granted Galotti's extradition to Naples on the condition that he would not be prosecuted for political offences. Upon Galotti's return to Naples, he was immediately sentenced to death for the participation in the revolution. The French threatened Naples with war and managed to get Galotti back to safety. ${ }^{21}$ As the Galotti case had provoked a public outcry, the new French government established more lenient rules against political offenders, including milder penalties in comparison to ordinary crimes. Around the same time, the principle of non-extradition in international treaties and the right of asylum in political matters emerged. ${ }^{22}$ According to Christopher H. Pyle, "Romanticism, couched in the language of social science, led countries like France to treat domestic political criminals with leniency." 23

Otto Kirchheimer has described the way political offenders were seen between the 1830s until the First World War in the following way:

The state, it was reasoned, had to safeguard itself against its foes, but this did not necessarily imply a need to stamp one's foe as a dishonourable man and a scoundrel. Whatever part psychological and sociological optimism and romanticism played in this attitude, where it obtained it included the granting of special privileges to the political offender: a scale of so-called parallel punishments, including at times the abolition of the death penalty and the creation of some form of custodia bonesta, lacking any dishonourable connotation, was worked out; and there was a minimum special treatment under ordinary prison conditions and non-imposition of loss of civil rights. ${ }^{24}$

18 Ingraham and Tokoro, 1969, 154.

19 Van den Wijngaert, 1980, 3.

20 American Journal of International Law, Introductory Comment, Supplement, 1935, 45; Pyle, 2001, 81.

21 Deere, 1933, 250; Van den Wijngaert, 1980, 12.

22 Ferrari, 1920, 311; Ingraham and Tokoro, 1969, 146, 152; Van den Wijngaert, 1980, 12.

23 Pyle, 2001, 82.

24 Kirchheimer, 1961, 40. 
The political offence exemption was first codified in newly independent Belgium's Extradition Act of $1833 .^{25}$ The act was also the first to codify legal rules concerning extradition, as previously extradition had been handled at the executive level only. ${ }^{26}$

The emergence of the political offence exemption to extradition was connected to a wider change of ideals. Belgium had gained its independence through a process that began with a violent revolt against the Dutch King William I and provided an example of a legitimate government being born from a rebellion. ${ }^{27}$ The Belgian clause can be interpreted as a direct reaction to these historical developments providing a means to support rebels elsewhere.

Internationally, the clause was introduced in the Franco-Belgian treaty of 1834, and added to the French bilateral treaties with the United States in 1843 and England in 1852. ${ }^{28}$ The political offence exemption in extradition treaties had varying provisions and different wordings, but its contents remained essentially unchanged: political offenders were to be excluded from the scope of mandatory extradition the treaties provided for. ${ }^{29}$ Typically, the scope of political offences was not defined or in any way limited.

Because the typical extradition treaty contained a list of extraditable offences, which never included 'pure' political crimes, it can be claimed that the existence of the POE was based on the idea that offenders who commit relative political offences are worthy of protection. In other words, crimes listed in the treaty can be protected from extradition, provided they are considered political in nature.

As foreign political criminals were now considered to be heroes rising against tyranny, the exemption to extradition became a way of supporting their battles. Its coming into being was a result of both new political ideologies, as well as practical strategic views by the states. Based on the idea that the "enemy of my enemy is a friend," it provided states with the possibility to support rebellious action in their enemy states without participating in a war themselves. It reflected the new view according to which democracies could be established through rebellion. In addition, the POE made diplomacy less complicated, because the protection of political offenders became standard practice. As a result, political offenders, who had been the cause for which the practice of extradition had originally been created, now became sheltered from it.

Yet, the more lenient treatment of political criminals was not only a result of defending these 'altruistic' and 'honourable' criminals but also of the belief that they could not be deterred by punishment. As a result, the death penalty for political crimes was abolished in France in 1848. For the same reason, political

25 See e.g. García-Mora, 1956, 75; Garcia-Mora, 1962, 1231; Sofaer, 1986, 126; Pyle, $2001,82$.

26 Van den Wijngaert, 1980, 12; Oppenheim, Jennings and Watts, 1992, 954.

27 See e.g. Mulligan, 2006, 405.

28 García-Mora, 1956, 75; Van den Wijngaert, 1980, 13.

29 Other limitations were also included in the treaties, but this study concentrates purely on the political offence exception. 
criminals had milder imprisonment conditions; they were treated more respectfully and forced labour as punishment for political crime was eliminated. For instance, France, Italy, Germany and Japan favoured political criminals in their punishment systems. ${ }^{30}$

M. Cherif Bassiouni has underlined that the primary aim of the POE, as well as other restrictions and limitations to extradition, was not the protection of the individual, but of the advantages of the states involved. The requested state has always had discretion in deciding whether the POE is applied and could apply it based on its self-interests. For this reason, Bassiouni had proposed in 1969 that there should be a juridical standard for the application of the POE. ${ }^{31}$ According to Christopher H. Pyle, the laws created for the protection of political offenders did not express sympathies for the political offenders but rather aimed at preventing them from becoming martyrs. ${ }^{32}$ This preferential treatment was first introduced on the domestic level and, only later, brought to international treaties on political asylum and the political offence exemption.

In some countries, the treatment of domestic political offenders differed notably from the treatment of foreign political offenders. If a political offence was committed within the state's own borders, the perpetrator was punished according to the laws of the state, even harshly. In cases where the crime had been committed abroad, the perpetrator could be set free due to the political motives of the act. ${ }^{33}$

According to Ingraham and Tokoro, the idea of a separate concept of political crime and toleration towards this type of criminals can only arise under very specific conditions:

(1) in which the dominant political philosophy was liberalism, (2) where the state's claim to legitimacy was infirm and relativistic, (3) where there was a clear division between the concept of the state (as merely representative of those interests in society politically in the ascendant) and the society as a whole, and (4) where the government's or the state bureaucracy's conception of itself was not as the representative of all the people of the society, but rather as the custodian or protector of a constitutional order which ensured the institutions constituting the source of its political and economic power. ${ }^{34}$

These conditions were met by most of the European parliamentary and constitutional-monarchical governments during the 19th century. Additionally, according to Ingraham and Tokoro, the more lenient treatment of political criminals related to the status of these criminals as (former) members of the ruling class.

30 Ingraham and Tokoro, 1969, 147.

31 Bassiouni, 1969, 224, 227.

32 Pyle, 2001, 81.

33 Coudert, 1909, 140.

34 Article 3, United States-Mexico Extradition Treaty, 22 February 1899. See "Political Offence," 1909. 
Thus the rebels could be seen as idealistic errant 'sons' and 'brothers. ${ }^{35}$ In addition, many revolutionary movements were initiated by students, and most political criminals represented the professional and intellectual segments of the bourgeoisie. $^{36}$

The 19th century gave room to the development of a new political atmosphere in which participation in the field of politics was available to a larger crowd than before. This gave way to the protection of political criminals but also to issues such as the general vote. No longer was it only the ruling class that could have a say in politics, but more voices could be heard. As the rights of citizens did not evolve at the same pace as the ideological change in a more accepting view of political participation, the POE can be seen to have been a 'vent' through which the desire for change could go through. If expressing dissenting opinions was still a crime in one country, another state could offer protection to this person who was not considered a criminal.

As such, the POE also represented a means through which the distrust between states could be expressed. It was a seemingly neutral and apolitical practice, as it was applied by the courts instead of the executive in most states. As such, it represented a way to express diplomatic disagreements in a sophisticated matter.

As the POE is historically related to the rise of democracies and liberalism, according to some, it is not ideologically neutral and should not be applied as such. Others have, in contrast, been of the opinion that courts as neutral organs should not take part in evaluating the legitimacy of political goals. For instance, Noone and Alexander have been sceptical of naming specific violent tactics 'illegitimate.' They have argued that the condemnation of specific violent tactics, which they understood to be a reaction to the threat of international terrorism could result in imposing an outsider's point of view on how internal political conflicts should be managed. ${ }^{37}$

\subsubsection{POE becomes widely accepted}

The sheltering of political criminals for ideological reasons became a common practice during the 19th century. The political offence exception spread across the world and became a part of most extradition treaties during the $1800 \mathrm{~s}^{38}$

Conservative regimes in Europe were at first opposed to the idea that political offenders needed protection and they attempted to pressurise smaller states to extraditing political offenders. ${ }^{39}$ In the 1830s, Prussia, Russia, Austria and

35 Ingraham and Tokoro, 1969, 154.

36 Ingraham and Tokoro, 1969, 167, footnote 34.

37 Noone and Alexander, 1997, 96.

38 See e.g. Ecuador International Extradition Treaty with the United States, 28 June 1872; Convention between the United States of America and the Austro-Hungarian Monarchy relating to Extradition for the Mutual Delivery of Criminals, Fugitives from Justice, in Certain Cases, 3 July 1856; Traité d'Extradition entre la France et la Grèce, 11 April 1906.

39 Pyle, 2001, 80. 
later also Spain agreed to extradite those political criminals who were plotting or acting against the crown. However, with the growing need to create extradition agreements with liberal states, autocratic states were also coerced to accepting the POE from the 1850 s onwards. ${ }^{40}$

Since its independence in 1776, the newborn nation of the United States had come to be known as a site of political asylum for fugitives from around the world, especially Europe. ${ }^{41}$ The 'old world' was considered a nest for tyrants, due to which those fleeing it deserved protection. ${ }^{42}$ For instance, US President Tyler (1841-1845) made a public statement that persons engaging in revolutions for liberty would not be extradited. ${ }^{43}$ For this reason, the POE was consistently used in US extradition treaties.

The last 'old fashioned' US extradition treaty that did not contain the POE was the Webster-Ashburton Treaty of 1842 with Great Britain (United Kingdom). ${ }^{44}$ The aim of the Webster-Ashburton Treaty was in contradiction with the growing trend of protecting political offenders of the era. It specifically targeted politically motivated criminals who sought to escape justice by crossing the vast US-Canada border. According to Christopher H. Pyle, Article 10, which contained the extradition provisions for serious crimes such as "murder, or assault with intent to commit murder, or Piracy, or arson, or robbery, or Forgery, or the utterance of forged paper" 45 was "In modern parlance [... intended to end 'terrorism." 46

The collaboration in the capturing of political offenders could be related to the contemporary political conditions in the US and Great Britain. In the early decades of the 1800s, Britain had liberalised and, similarly to the US, turned into an asylum for political offenders who had partaken in liberal revolutions in Continental Europe. The political relations between the US and Britain had normalised, and the US supported Britain against the conservative regimes of Prussia, Austria and Naples. As the two nations had converging views over who deserved protection, the POE was not necessary. Additionally, the treaty left other possibilities to deny extradition for political offenders. Regardless, the lack of the POE was criticised in the US Congress. ${ }^{47}$

40 Pyle, 2001, 83.

41 Clark, 1909, 120. See also e.g. Deere, 1933, 268; Evans, 1969, 204; Stanbrook and Stanbrook, 2000, vii-viii; Pyle, 2001, 115.

42 Pyle, 2001, 79.

43 McElrath, 2000, 8.

44 The Webster-Ashburton Treaty. Treaty to Settle and Define the Boundaries between the Territories of the United States and the Possessions of Her Britannic Majesty in North America, for the Final Suppression of the African Slave Trade, and for the Giving Up of Criminals Fugitive from Justice, in Certain Cases, 9 August 1842. See Pyle, 2001, 68, for more details on this treaty.

45 Article 10, The Webster-Ashburton Treaty, 9 August 1842.

46 Pyle, 2001, 72.

47 Pyle, 2001, 67-75. 
The POE was introduced to US extradition conventions in the 1843 treaty with France. ${ }^{48}$ Since then, it was added to all US extradition treaties studied ${ }^{49}$ except for the 1852 treaty with Germany (Prussia and Germanic Confederation). ${ }^{50}$ The scope of the POE in the US-France treaty was more limited than in future US extradition treaties. It denied extradition only for crimes or offences "of a purely political character." 51 Such provision was actually unnecessary. As extradition provisions of that era typically did, this treaty contained a limited list of extraditable offences, which did not incorporate any 'purely political' offences. ${ }^{52}$ In other words, purely political crimes would not have been extraditable even if the POE would have not been included in the treaty.

Along with the US-Mexico treaty of $1899,{ }^{53}$ the US-France treaty was the only US extradition treaty to limit the POE to pure political crimes. It is possible that between the then-liberal government of France and the US a wider exemption was not considered necessary. ${ }^{54}$ Interestingly enough, as discussed in Chapter 5, Section 5.1.1, the POE in the US-France treaty of 1996 covered a wide range of crimes that were connected with political offences as well as crimes inspired by political motives.

The fact that all US extradition treaties, except for one, since the French treaty of 1843 contained the POE can be seen to represent a quick breakthrough of the liberalist ideology that considered political offenders as a special class of criminals, worthy of protection. It is interesting that this solution became diplomatically acceptable, as invoking the POE is essentially a way of expressing distrust in the impartiality of the judiciary of the requesting state. ${ }^{55}$

48 Convention for the Surrender of Criminals between the United States of America and His Majesty the King of the French, 8 Stat. 580 (1844), 9 November 1843.

49 See Appendix.

50 Convention for the Mutual Delivery of Criminals, United States and Germany (Prussia and Germanic Confederation), 16 June 1852.

51 Article 5, Convention for the Surrender of Criminals between the United States of America and His Majesty the King of the French, 8 Stat. 580 (1844), 9 November 1843.

52 The offences extradition was granted for were: "murder, (comprehending the crimes designated in the French Penal Code by the terms, assassination, parricide, infanticide, and poisoning,) or with an attempt to commit murder, or with rape, or with forgery, or with arson, or with embezzlement by public officers, when the same is punishable with infamous punishment." Article 2, Convention for the Surrender of Criminals between the United States of America and His Majesty the King of the French, 8 Stat. 580 (1844), 9 November 1843. Even if a typical extradition treaty in the 19th century provided for a list of extraditable crimes which did not include pure political offences, for instance Samuel T. Spear saw it to be unclear whether the POE protected those who committed relative political offences. Spear, 1885,50 .

53 Article 3, United States-Mexico Extradition Treaty, 22 February 1899.

54 Pyle, 2001, 74. Also David Dudley Field in his well-known study "Outlines of an International Code" suggested that only pure political crimes should be exempted from extradition. Art. 215 (1), Field, 1876, 108.

55 Gilbert, 1985, 695. 
Coming to the 1860s, the POE had become a common feature in most extradition treaties between Western states. ${ }^{56}$ The importance of the POE was also reinforced by the esteemed Institute of International Law at its Oxford meeting in 1880. In the resolution finalised at the meeting, it was suggested that political acts should be excluded from the scope of extradition. ${ }^{57}$ In 1892 its Geneva session confirmed this view. ${ }^{58}$ The POE also received support from the First South American Congress on Private International Law held in $1889 .{ }^{59}$

The Institute of International Law (IIL) specifically discussed the need to protect both pure and relative political offences, "provided the crimes are not of the graver sort, from the point of view of morals and the ordinary penal law." Such grave crimes were listed to include "assassination, murder, poisoning, mutilations and severe wilful and premeditated woundings, attempts to commit crimes of these sorts, and attacks against property by burning, explosion, inundation, as well as grand larceny, especially those that are committed with weapons in hand and with violence." Also, crimes committed during an insurrection or civil war were to be excluded from the scope of extradition, "unless these acts constitute acts of odious barbarity and of vandalism which are prohibited by the laws of war." ${ }^{60}$ The limitations the IIL set for the POE only became more common after the threat of terrorism spread in the West since the 1970s, as argued in this book. The limitations with regard to damage to property only emerged on the legislative level at the beginning of the $2000 \mathrm{~s}^{61}$ and are still not widely accepted.

Some states regard the POE as a rule established under international law. ${ }^{62}$ The fact that the exception is incorporated into a vast amount of extradition treaties, especially in Western countries, would support this claim. ${ }^{63}$ However, this view is controversial. ${ }^{64}$ For instance, Oppenheim's widely cited Handbook in

56 Pyle, 2001, 83.

57 Article 13: "L'extradition ne peut avoir lieu pour faits politiques." Justifia et Pace, Institut de Droit International, Session d'Oxford, Résolutions d'Oxford (Extradition), 9 September 1880.

58 Cited in Ferrari, 1920, 310-1. An agreement with a similar provision was soon concluded by the US and Mexico in 1899. Extradition Treaty with Mexico, 22 February 1899, Article III, para. 2, 31 Stat. 1818. Garcia-Mora, 1962, 1231.

59 Article 16, First South American Congress on Private International Law, Treaty on International Penal Law, 23 January 1889.

60 Article 2, Révision des articles 13 et 14 des Résolutions d'Oxford (Extradition) Justifia et Pace, Institut de Droit International, Session de Genève, 8 September 1892. Translation/ citation in Ferrari, 1920, 310-311.

61 See in more detail Chapter 5, Section 5.2.3.

62 Gilbert, 1985, 696.

63 See Van den Wijngaert, 1980, 1, for a list of treaties where this principle was incorporated in 1980. See also the Appendix of this book with a list of US extradition treaties.

64 For instance, only recently, in 2010 Michael Abbell wrote: "In 1834, France introduced the political offence exception into its treaties, and by the 1850's it had become a general principle of international law incorporated in the extradition treaties of Belgium, England, and the United States as well." Abbell, 2010, 115, italics added. Then again, Gilbert has noted that according to most commentators and cases, it seems that the POE is a matter of state practice, not international law. Gilbert, 1991, 117. 
International Law claims that "Political criminals are, as a rule, not extradited," 65 but, at the same time, it comes to the conclusion that there probably is no rule of international customary law that prevents the extradition of political criminals. ${ }^{66}$

In 1935, a group of American legal scholars and jurists published a Draft Convention on Extradition, as a part of a wider series of drafts in key questions in international law organised by Harvard Law School. The League of Nations had attempted to create a draft convention on the matter in 1925, but failed. The aim of the 1935 convention was to provide for a starting point for a wider codification of international law. It contained the POE and gave the following description of political offences for the purposes of its application:

As it is used in this Convention, the term 'political offence' includes treason, sedition and espionage, whether committed by one or more persons; it includes any offence connected with the activities of an organised group directed against the security or governmental system of the requesting State; and it does not exclude other offenses having a political objective. ${ }^{67}$

A heated debate on whether the non-extradition of political offenders is a rule of international law was provoked by the European Convention on the Suppression of Terrorism signed in 1977. ${ }^{68}$ The convention excluded terrorism from the scope of the political offence exception. Some experts argued that this was a derogation from a principle of international law. A conclusive answer to whether it actually was such was not found. ${ }^{69}$

Regardless of its widespread usage, the POE never became standard practice in all extradition treaties. For instance, the Commonwealth Fugitive Offenders Act of 1881, aiming at protecting persons against injustice, oppression and undue punishment did not contain the POE. ${ }^{70}$ Even if it could be explained by the political unity of the Empire, the lack of the POE was considered controversial. Once the Commonwealth countries gained independence, the need for the creation of new extradition treaties incorporating the POE emerged. The new Commonwealth Scheme Relating to the Rendition of Fugitive Offenders of 1966

65 Oppenheim, Jennings and Watts, 1992, 959.

66 Oppenheim, Jennings and Watts, 1992, 963.

67 Art. 5, Draft Convention on Extradition (Harvard Draft). See American Journal of International Law, General Introduction, Supplement, 1935, 1-14.

68 The details of this convention are discussed in Chapter 4, Section 4.1.5.

69 Van den Wijngaert, 1980, 43-44: "Briefly summarised, both parties based their conclusions on the following data in international extradition law: (i) the political offence exception is a generally accepted principle in extradition law. This can be deduced from the general incidence of the rule in extradition laws and treaties; (ii) may extradition laws and treaties have, however, provided for exceptions to the political offence exception; (iii) except for the Genocide Convention, such exceptions were never generally accepted, and several times, proposals to restrict the political offence exception in international treaties were rejected."

70 Commonwealth Fugitive Offenders Act of 1881, 44 and 45 Vic. c. 69 (Imperial). See also Oppenheim, Jennings and Watts, 1992, 966. 
included all the standard features of modern extradition treaty practice, including the POE. ${ }^{71}$

Even if the POE became commonly used, its formulations were not consistent. Soon it also became subject to limitations. However, the formulations and the limitations did not make the POE lose its essence, at least not before the 1980s.

A notable amount of early extradition treaties used the British Extradition Act of 1870 as a model. The act contained the following formulation of the POE: "The provisions of this Convention shall not import a claim of extradition for any crime or offence of a political character, nor for acts connected with such crimes or offences; and no person surrendered by or to either of the Contracting Parties in virtue of this Convention shall be tried or punished for a political crime or offence." 72 This, according to García-Mora, "set the pattern for the standard treatment of relative political offences in Anglo-American law."73

Other types of formulations were also widely used. For instance, according to the Montevideo Convention on Extradition, adopted by the American Republics in 1933, extradition could be denied "when the offence is of a political nature or of a character related thereto." ${ }^{74}$ Article 4 of the Pan American Convention on Territorial Asylum of $1954^{75}$ stipulated that the "right of extradition is not applicable in connection with persons who, in accordance with the qualifications of the solicited State, are sought for political offences, or for common offences committed for political ends, or when extradition is solicited for predominantly political motives." The European Convention on Extradition from 1957 provides that extradition may not be granted for "political acts." Another formula excludes a person from the scope of extradition "when the crime or offence for which the person's extradition is requested is of a political character." 76 A common formulation has been to exclude "political offences or acts connected therewith" (Actes connexes in the French version). ${ }^{77}$

The British Extradition Act of 1870 had repeated the inclusion of 'connected offences' in addition to crimes of a political character that had its roots already

71 Commonwealth 1966: Rendition of Fugitive Offenders within the Commonwealth (Cm 3008, 1966). Oppenheim, Jennings and Watts, 1992, 967; Stanbrook and Stanbrook, 2000, 11.

72 s3(1) Extradition Act, 1870 (33 and 34 Vict. c. 52); Gilbert, 1991, 121; Abbell, 2010, 115. The POE was repeated in the same form in the s4(1)(a) Fugitive Offenders Act 1967 and in s2(2)(a) Backing of Warrants (Republic of Ireland) Act 1965. Gilbert, 1991, 121.

73 Garcia-Mora, 1962, 1240. See also Oppenheim, Jennings and Watts, 1992, 954.

74 Article 3 (e) Convention on extradition adopted by the seventh International Conference of American States, 26 December 1933 (Montevideo Convention).

75 The Pan American Convention on Territorial Asylum, 28 March 1954.

76 See e.g. Extradition Treaty of 13 January 1961 between the United States and Brazil.

77 The concept of 'connected offence' was not generally accepted in common law countries, but it has persisted in the French language. For instance it has been included in the French version of the European Convention on Extradition. Stanbrook and Stanbrook, 2000, 5. Such a clause was included for instance in the Convention Concerning Extradition and Judicial Assistance in Criminal Matters, between Israel and Italy on 24 February 1956. 
in the 1833 Belgian Extradition Act and the 1834 Belgian-French treaty. ${ }^{78}$ This widened the coverage of the exception and seems to have made it applicable also to a variety of offences. ${ }^{79}$

This feature was commonly used. For instance, the US-Belgium extradition treaty of 1882 stated: "The provisions of this convention shall not be applicable to persons guilty of any political crime or offence or of one connected with such a crime or offence." 80

However, even if this clause was codified in the British Extradition Act, it was not added to all UK treaties. For instance, it was not included in the UKArgentine treaty of $1889 .{ }^{81}$ By comparison, the United States incorporated the exclusion of connected offences to a fifth of its extradition treaties. ${ }^{82}$ No US case apparently ever dealt with connected offences, but according to Michael Abbell, the connection between the connected crime and the political offence would have needed to be straightforward. If a suspect was sought for different acts, some of political and some of common character, their extradition could have been denied for the offences of a political character, but still granted for the common offences. ${ }^{83}$

In addition to extending the POE to connected offences, the British Extradition Act of 1870 also provided for the denial of extradition in case it seemed that the motivation behind the request was to punish the fugitive for a political offence. ${ }^{84}$ The same clause was added to for instance the US-Colombia treaty from 1888: "If it be made to appear that the extradition is sought with the view of trying or punishing the person demanded for an offence of a political character, surrender shall not take place; nor shall any person be tried or punished for a political offence, committed previously to extradition, or for any offence other than that for which extradition was granted." 85 Similarly, almost a century later, the 1970 Spain-US treaty provided that extradition could be denied if "[the requested] Party has substantial grounds for believing that the request for

78 Garcia-Mora, 1962, 1240. It was also repeated in later French-Belgian treaties. Article 2, Convention d'extradition France-Belgique 29 April 1869. See also Article 3, Convention d'extradition France-Belgique 15 August 1874; Article 4, Traité d'extradition entre la France et la Pologne, 30 December 1925; Treaty on extradition between France and the United Kingdom of Great Britain and Northern Ireland, 14 August 1876.

79 The idea of "connected offences" was alive still after the Second World War. See e.g. Convention on Extradition between the United States of America and Sweden, 24 October 1961, Article 5. See also Garcia-Mora, 1962, 1232.

80 Article 4, US-Belgium extradition treaty, 13 June 1882.

81 Article 6, United Kingdom-Argentina Treaty for the mutual extradition of fugitive criminals, 22 May 1889, as amended by the Protocol of 12 December 1890.

82 Twenty-five out of the 121 treaties studied. See Appendix with the listing of all US extradition treaties and their contents.

83 Abbell, 2010, 117-118.

84 s3(1) Extradition Act, 1870.

85 Article 5, Convention between the United States of America and Colombia for the reciprocal extradition of criminals, 7 May 1888. 


\section{Rise and decline of romantic liberalism}

extradition has been made for the purpose of trying or punishing a person for an offence of the above-mentioned character." 86 The provision was also added to the so-called Bustamante code, which was an attempt to establish common rules amongst American states in $1928 .{ }^{87}$

This provision is closely related to the discrimination clause, as it requires the requested state to evaluate the motives behind the request. However, where the discrimination clause is applied when it is suspected that the fugitive cannot receive fair treatment in the requesting country, this clause necessitated that the fugitive was in fact wanted for another crime than the one the request was made for.

A less protective view was offered by for instance the treaty between the US and the UK from 1889, which stated that a "fugitive criminal shall not be surrendered if the offence in respect of which his surrender is demanded be of a political character, or if he proves that the requisition for his surrender has, in fact, been made with a view to try to punish him for an offence of a political character." 88 Similar or identical wordings can be found in many extradition treaties between different countries from the same period. ${ }^{89}$ As opposed to the Colombia treaty, where a suspicion that the fugitive was requested for other crimes than the ones they were sought for was enough, this provision left the burden of proof on the matter to the fugitive himself. This formulation was used in US extradition treaties for a long time, and it was included in for instance the 1947 treaty with South

86 Article 5/A/4, Spain International Extradition Treaty with the United States, 29 May 1970. A similar provision is in Article 7 of the Treaty on Extradition between the Kingdom of Denmark and the United States of America, 22 June 1972: "if the requested State has reason to assume that the requisition for his surrender has, in fact, been made with a view to try or punish him for a political offence or an offence connected with a political offence." Also see Article 4 of the Extradition Treaty with the Federal Republic of Germany, 20 June 1978. Article 4 of the Japan International Extradition Treaty with the United States (3 March 1978 ) allows the court to consider whether the request appears to be politically motivated.

87 Article 356, Código de Derecho Internacional Privado (Código de Bustamante) Convención de Derecho Internacional Privado, 20 February 1928.

88 Convention between the United Kingdom and the United States of America for the Mutual Extradition of Fugitive Criminals, 12 July 1889. See also the identical provisions in other extradition treaties between the US and the UK. Article 6, Extradition Treaty between His Majesty, in respect of the United Kingdom, and the President of the United States of America, 22 December 1931.

89 See e.g. Article 5, Treaty on Extradition between France and the United Kingdom of Great Britain and Northern Ireland, 14 August 1876; Article 6 Treaty between the United Kingdom and Finland for the Extradition of Criminals, 30 May 1924; "L'extradition ne sera pas accordée si l'infraction pour laquelle elle est demandée, est considérée par la partie requise comme un délit politique ou un fait connexe à un semblable délit, ou sit l'individu réclamé prouve que la demande d'extradition a été faite en réalité dans le but de le poursuivre pour une infraction de cette nature." Article 6, Traité d'Extradition entre la France et la Grèce, 11 April 1906; Article 6, Convention d'extradition entre la France et les Etats-Unis d'Amérique, 6 January 1909; Article 6, Convention d'extradition entre la Bulgarie et la France, 29 December 1911; Article 6, Treaty between Great Britain and Latvia for the Extradition of Criminals, 16 July 1924. 
Africa, ${ }^{90}$ the 1971 treaty with Canada, ${ }^{91}$ the 1972 treaty with Argentina ${ }^{92}$ and the 1973 treaty with Italy ${ }^{93}$ among others. ${ }^{94}$

Abbell has pointed out that this provision requires the requested state taking a position on the internal politics of the requesting country. As this is a foreign policy matter, courts have been reluctant to take a stance with regard to it. ${ }^{95}$

\subsubsection{Exception to the exception: the attentat clause of 1856}

The man in the street would recoil in horror should you ask him to class as equally entitled to asylum on American soil men like Lafayette or Carl Schurz and the Communists of 1870 who cruelly tortured and killed, General Breda, an honourable and distinguished officer, who, desiring to save useless bloodshed, presented himself with a white flag as a messenger of peace. The spontaneous differentiation which the universal instinct of every civilised community would make between such cases, may not as yet correspond to any legal distinction $[\ldots]{ }^{96}$

As discussed earlier, the key problem of the political offence exception to extradition has been the definition of political offences and their varied nature. The concept has often seemed to cover a variety of deeds, more or less connected with politics, from non-violent resistance to the state to extremely violent attacks against civilians. Thus the category is open to many different types of offenders, but the special treatment considers them to be only one homogenous group.

The statement opening this section was given by Mr Frederic R. Coudert of New York City at the Annual Meeting of the American Society of International Law in 1909. He continued:

The query is: can some method be found, by which international law, keeping in touch with the moral requirements of the age, shall differentiate between those who have sought refuge here, after having honestly and fairly - although by revolutionary methods - sought to change or modify, a governmental system, and those who, although their acts may have been inspired by political motives, have yet been guilty of acts generally reprobated by all civilised nations? ${ }^{97}$

90 Article 6, Treaty between the United States of America and the Union of South Africa Relating to Extradition, 18 December 1947.

91 Article 4, Treaty on Extradition between the Government of Canada and the Government of the United States of America, 3 December 1971.

92 Article 7, Treaty on Extradition between the United States of America and the Republic of Argentina, 21 January 1972.

93 Article 6, Treaty on Extradition between the United States of America and Italy, 18 January 1973.

94 Article 4, Treaty on Extradition between the United States of America and the Republic of Paraguay, 24 May 1973; Article 7, Extradition Treaty between the United States of America and Finland, 11 June 1976; Article 7, Extradition Treaty between the United States of America and the Kingdom of Norway, 9 June 1977.

95 Abbell, 2010, 118.

96 Coudert, 1909, 126.

97 Coudert, 1909, 127. 
In the same meeting, J. Reuben Clark, assistant solicitor of the Department of State, also questioned whether there could not be a political act that was so barbarous that it should not be protected by the exception and whether the limits should be similar to the rules of war. ${ }^{98}$

Since its early days, the political offence exception created diplomatic problems. There is still no conclusive agreement on how to distinguish political crimes from common crimes and justified political crimes from non-justified ones. Creating exceptions to the political offence exemption has been an attempt to tackle at least part of the problem. With exceptions to the exception, some of the most violent crimes, sometimes including terrorism, have been more or less successfully excluded from the scope of the protection.

Soon after the creation of the POE, it became obvious that it offered protection to persons who were able to destabilise the fragile new world order. These people were the assassins of heads of state. Two decades after the creation of the POE, the so-called Belgium clause, later better known as the attentat clause, was created to exclude this form of political violence from the scope of protection of the POE. The clause was the first where depoliticisation was used with regard to a specific violent act.

The attentat clause was introduced as a reaction to the Jacquin case, where France requested the extradition of Celestin Jacquin, who allegedly had attempted to kill Emperor Napoleon the III. The request was turned down by the Court of Appeal of Brussels, on account of the political offence exception. This decision caused a major diplomatic problem. Finally, France withdrew its request but pressured Belgium into adding a clause preventing the application of the POE in similar future cases. ${ }^{99}$ The text was as follows:

Ne sera pas repute délit politique ni fait connexe à semblable délit, l'attentat contre la personne du chef d'un gouvernement étranger ou contre celle des membres de sa famille lorsque cet attentat constitue le fait, soit de meurtre, soit d'assassinat, soit d'empoisonnement. ${ }^{100}$

In other words, this provision thus excluded attacks against the life of a head of state or their family members from the scope of the protection of the POE and thus depoliticised these acts.

The attentat clause became a widely accepted standard in extradition treaties. ${ }^{101}$ Its use was recommended by the Anti-Anarchist Conference of Rome in

98 Clark, 1909, 122-123. Raising the topic on the rules of war with regard to terrorist violence has been repeated quite often since then. Some have argued that terrorism should be punished under these rules, whereas others have stated that this is impossible as terrorism is a violent act committed during times of peace.

99 Deere, 1933, 252; Van den Wijngaert, 1980, 15; Sofaer, 1986, 127.

100 Cited in Van den Wijngaert, 1980, 15.

101 See e.g. Oppenheim, Jennings and Watts, 1992, 969. 
$1898,{ }^{102}$ and according to Richard Bach Jensen, this led to its spread into most European countries before World War I. ${ }^{103}$

The contents of the clause have varied, sometimes covering only attacks against the lives of heads of state, but sometimes also those of their families or members of the government. In some cases, it has covered different types of violent acts, and sometimes only murders. Typical wording for the attentat clause can be found for instance in the US-Belgium treaty of 1882: "An attempt against the life of the head of a foreign Government, or against that of any member of his family, when such attempt comprises the act either of murder or assassination, or of poisoning, shall not be considered a political offence or an act connected with such an offence."104

The Belgian treaty introduced the clause to US extradition treaties. It was drawn soon after the assassination of US President Garfield, so it is possible to interpret the adding of the clause as a reaction to this event. The same clause formed a part of many later treaties but was formulated a bit differently. ${ }^{105}$ For instance, in the 1909 Honduras International Extradition Treaty with the United States, ${ }^{106}$ "When the offence charged comprises the act either of murder or assassination or of poisoning, either consummated or attempted, the fact that the offence was committed or attempted against the life of the sovereign or head of a foreign state or against the life of any member of his family, shall not be deemed sufficient to sustain that such a crime or offence was of a political character, or was an act connected with crimes or offences of a political character." A similar provision was added by the United States to the 1911 Treaty

102 Discussed in detail in Section 3.2.

103 Jensen, 1981, 330-331.

104 Article 4, US-Belgium extradition treaty, 13 June 1882. See also Spears, 1885, 49. The same provision was added for instance to the Extradition Treaty between Guatemala and the USA, 27 February 1903. In French, a nearly identical formulation can be found for instance in the Franco-Belgian treaty of 1869: "Ne sera pas réputé délit politique ni fait connexe à un semblable délit l'attentat contre la personne d'un souverain étranger ou contre celles des membres de sa famille, lorsque cet attentat constituera le fait soit de meurtre, soit d'assassinat, soit d'empoisonnement" (Article 2, Convention d'extradition France-Belgique, 29 April 1869). In the Franco-Belgian treaty of 1874, the formulation "souverain étranger" was changed to "Chef d'un état étranger." See also e.g. Article 8, France-SaxeWeimar: Convention d'extradition, 7 August 1858; Article 4, Traité d'extradition entre la France et la Pologne, 30 December 1925.

105 See e.g. the extradition treaty between the United States of America and Turkey from 1923, where the formulation talks about "political crimes or offences" instead of just "political offences." Article 3, Extradition Treaty between the United States of America and Turkey, 6 August 1923. The same provision was for instance in the Greece International Extradition Treaty with the United States, 6 May 1931, Article 3. However, the 1979 treaty with Turkey talks about offences of political character. Article 3, Treaty on Extradition and Mutual Assistance in Criminal Matters between the United States of America and the Republic of Turkey, 7 June 1979.

106 Article 3, Honduras International Extradition Treaty with the United States, 15 January 1909. 
of Extradition with El Salvador, ${ }^{107}$ to the 1923 treaty with Estonia, ${ }^{108}$ the 1925 treaty with the Czech Republic, ${ }^{109}$ the 1927 treaty with Poland, ${ }^{110}$ the 1930 treaty with Austria ${ }^{111}$ and the 1931 treaty with Greece. ${ }^{112}$ Also, the 1933 InterAmerican Convention on Extradition states that attempts "against the life or person of the Chief of State or member of his family shall not be deemed to be a political offence."113

The difference between this provision and the earlier versions lay in the way the depoliticisation was done. The US-Belgium treaty of 1882 was the first one in US extradition treaties to depoliticise certain acts, but the later treaties had a much stronger formula of depoliticisation. Whilst the Belgian treaty along with others marked that an attempt against the life of a head of state or their family member "shall not be considered a political offence," 114 for instance, the Honduras treaty stated that such an attempt "shall not be deemed sufficient to sustain that such a crime or offence was of a political character."115

The first formulation used in the US-Belgium treaty merely suggests that for the purposes of the treaty, the crimes shall not be considered political; in other words, the formulation talks about how the crimes are treated. The formulation in the Honduras treaty, in turn, expresses that the nature of such crime is not political. Even if the outcome of these statements might be identical, the second formulation is interesting as it denies the political nature of a pronouncedly political act: the killing of a head of state. ${ }^{116}$

107 Article 3, Treaty of Extradition between the United States of America and El Salvador, 18 April 1911.

108 Article 3, Extradition Convention between the United States of America and Estonia, 8 November 1923.

109 Article 3, Czech Republic International Extradition Treaty with the United States, 2 July 1925.

110 Article 3, Treaty of Extradition between the United States of America and the Republic of Poland, 22 November 1927.

111 Article 3, Convention between the United States of America and Austria Regarding the Reciprocal Extradition of Criminals, 31 January 1930.

112 Article 3, Greece International Extradition Treaty with the United States, 6 May 1931. See also Article 4, Extradition Treaty with the Federal Republic of Germany, 20 June 1978.

113 Article 3(e), Article 3, Convention on Extradition Adopted by the Seventh International Conference of American States, 26 December 1933.

114 See e.g. the 1933 Inter-American Convention on Extradition that states that extradition may not be granted when the offence is of a political nature or of a character related thereto. Article 3(e) of the Montevideo Convention 1933 also states that attempts "against the life or person of the Chief of State or member of his family shall not be deemed to be a political offence." See also Article 5, Mexico International Extradition Treaty with the United States, 4 May 1978.

115 Article 3, Honduras International Extradition Treaty with the United States, 15 January 1909.

116 For instance Colin Wight has argued that political assassinations should not be labelled terrorism. "To claim that an action is not terrorism but political assassination is not to justify it, or excuse it. So to reiterate, groups that explicitly target only state actors should not be labelled terrorist." Wight, 2015, 117. 
The application of the attentat clause was never consistent. In some cases, the POE was applied to protect those who had committed an attack against a head of state. For instance, an Italian court found in 1934 the murder of King Alexander of Yugoslavia to be a political offence. ${ }^{117}$ When the attentat clause was added to the European Convention on Extradition of 1957, the first multilateral convention on extradition in Europe, 5 out of the 19 signatory states of the European Convention on Extradition, formulated a reservation with regard to it, retaining the right to, in some cases, treat the killing of a head of state as a political crime. ${ }^{118}$ The attentat clause persisted well over a century, during which period it typically remained the only limitation to the POE. ${ }^{119}$

In addition to excluding attacks against heads of state, some extradition treaties depoliticised all crimes against life and thus excluded them from the political offence exception. An example of this can be found in the aforementioned resolutions of the Institute of International Law Geneva meeting in 1892. This was however not common practice. Usually, other criteria were also invoked. ${ }^{120}$

The exclusion of all crimes against life, the so-called unqualified attentat clause, was added to the Model Draft of an Extradition Treaty prepared by a SubCommission of the International Penal and Prison Commission in 1931, which excluded from the scope of the POE all murders and attempted murders "if they are committed with special barbarity or cruelty." 121 The Arab States and Arab League Extradition Agreement of 1952, excluded, in addition to "crimes of assault against monarchs, presidents of States, their spouses or their direct descendants," "crimes of assault against crown princes" and "crimes of premeditated murder" as well as "terroristic crimes" from the scope of political offences. ${ }^{122}$ This treaty was the first multilateral extradition treaty to do such an exclusion. The agreement was signed by Egypt, Iraq, Jordan, Lebanon, Saudi Arabia and Syria, and ratified by Egypt (with reservations concerning the limitations to the POE), Jordan and Saudi Arabia. ${ }^{123}$

The unqualified attentat clause was not typically used in US bilateral extradition treaties. However, the 1930 extradition treaty with Germany and the US contained the following version of it: "However, a wilful crime against human life, except in battle or an open combat, shall in no case be deemed a crime

117 See Section 3.2.5 or a detailed discussion on the case. Van den Wijngaert, 1980, 136-37.

118 Article 3, European Convention on Extradition Paris, Treaty Series No. 24, 13 December 1957.

119 See e.g. Article 3, Treaty between the Kingdom of Belgium, the Grand Duchy of Luxembourg, and the Kingdom of the Netherlands Concerning Extradition and Mutual Assistance in Criminal Matters, 27 June 1962.

120 Van den Wijngaert, 1980, 139.

121 Cited in Green, 1962, 339. Green makes an interesting observation concerning the defining of political crime in this draft. Article 6 seems to suggest that also "ordinary" persons can thus be victims of political crime, but the same article seems to suggest that political crimes are such crimes that are directed against state authority only. Green, 1962, 340.

122 Article 4 (4), The Arab States and the Arab League Extradition Agreement, 14 September 1952.

123 Shearer, 1971, 52. 
of a political character or an act connected with crimes of offences of such character." 124 The German Extradition Act of 1929 contained a similar provision.

Also the French-German treaty of 1951 excluded crimes against life committed outside of an open combat situation from the protection of the POE, but the formulation in this treaty was different to that of the US-Germany treaty: "Le caractère politique de l'infraction ne fera pas de plein droit obstacle à l'extradition dés lors qu'il s'agit d'un attentat à la vie non commis en combat ouvert." ${ }^{125}$ In other words, according to this treaty, the political character of the offences does not limit the possibility to extradite, while the US-German treaty depoliticised the mentioned crimes by saying that they were not be regarded as crimes of a political character.

An even more restrictive formulation of the POE can be found in two Finnish extradition treaties from the 1920s. In both the Estonia-Finland and the AustriaFinland treaty, all predominantly common crimes were excluded from the scope of the protection of the POE. ${ }^{126}$ The same exclusion was done in the USArgentina treaty of $1972,{ }^{127}$ but replaced with other, more common limitations in the renewed US-Argentina treaty of 1997. ${ }^{128}$ The US-Austria treaty of 1998 also categorically excluded murders from the political offences protected by the POE. ${ }^{129}$ The same is true of the 1999 treaty with South Africa. ${ }^{130}$ Such a provision has become more common in the 2000s. For instance, the Canada-Italy treaty

124 Article 4, Extradition Treaty between Germany and the United States of America, 12 July 1930.

125 Article 4, Décret n 59-1352 portant publication de la Convention franco-allemande d'extradition du 29 novembre 1951, 29 November 1951.

126 Article 3, Extradition Convention between Estonia and Finland, 2 January 1925; Article 3, Convention Relating to Extradition and Judicial Assistance in Criminal Matters between Austria and Finland, 22 October 1928. Not all Finnish extradition treaties contained this clause, e.g. the UK-Finland treaty dating from the same period did not have such an exclusion. See e.g. Article 6, Extradition Treaty between the United Kingdom and Finland, 30 May 1924.

127 Article 7, Treaty on Extradition between the United States of America and the Republic of Argentina, 21 January 1972: "Extradition shall not be granted in any of the following circumstances: e) When the offence in respect of which the extradition is requested is of a political character or is connected with an offence of a political character, or when the person whose extradition is requested proves that the extradition is requested for the purpose of trying or punishing him for an offence of the abovementioned character. The allegation of a political motive or end shall not impede the extradition if the alleged offence constitutes primarily a common offence, in which case the requested Party may request that the requesting Party give assurance that the political motive or end will not contribute to the aggravation of the penalty."

128 Article 4, Extradition Treaty between the Argentina Republic and the United States of America, 10 July 1997

129 Article 4, Extradition Treaty between the Government of the Republic of Austria and the Government of the United States of America, 8 January 1998.

130 Article 4, Extradition Treaty between the Government of the United States of America and the Government of the Republic of South Africa (with annex), 16.9.1999. See also Article 3 (1) (b) (c) and (d), Treaty between the Government of Canada and the Government of the Republic of South Africa on Extradition, 12 November 1999, excluding for instance murder, inflicting serious bodily harm and sexual assault from the protection of the POE. 
of 2005 excludes crimes such as the unlawful killing of a human being, inflicting serious bodily harm and criminal conduct of a sexual nature from the scope of political crimes. ${ }^{131}$

The unqualified attentat clause provides a strong ideological statement: no crime against life should be considered political. The application of this limitation more widely would have ended the controversies that later rendered the whole POE almost extinct. Then again, its application would have also prevented the protection to a number of political offenders whose actions have been seen as legitimate by some or many.

\subsubsection{Four reasons behind the political offence exception}

As described, the political offence exemption was born during an era of political turmoil during the Age of Revolution. As a new liberal ideology emerged, the political criminal was now seen as someone worthy of protection. For the purposes of this study, it is worth analysing the exemption a bit further. What did the political criminals deserve protection from? How was their status viewed?

Several considerations have motivated the creation of the POE. First, as their crimes target the institutional existence or structure of the state, political criminals are less likely to receive fair treatment than common criminals. For this reason, one of the aims of the exception has been to protect political criminals from unfair treatment, due to the political passions of those involved in the judicial process. $^{132}$

The protection from unfair trials is one of the main reasons for the pertinence of the POE. ${ }^{133}$ However, the efficiency of the exemption in serving this purpose is debatable. Other means, such as the discrimination clause, have been seen as more efficient and less problematic.

According to Miriam E. Sapiro, the exception is a "poor means" to accomplish the aim of protecting the political offenders from unfair trials. First, she has argued, it is wrong to assume that the political offender would necessarily receive arbitrary punishments. Second, non-political offenders who are not protected by the clause are at risk of being treated unfairly. Finally, other types of case-by-case protection mechanisms are available in cases where a political offence has been committed as a reaction to an illegal deed by the requesting state. ${ }^{134}$

Also, Bradley G. Kulman has been critical of the use of the POE in protecting fugitives from retaliatory trials. According to him, the fact that the POE has been incorporated into the majority of extradition treaties with those including

131 Article 3 (a) (ii) (iii) and (iv), Treaty between the Government of Canada and the Government of the Italian Republic Concerning Extradition, 13 January 2005.

132 See e.g. Deere, 1933, 250; Garcia-Mora, 1962, 1226; Bassiouni, 1969, 232; Vallée, 1976, 772 ; Petersen, $1992,776$.

133 See e.g. García-Mora, 1956, 75; Bassiouni, 1969, 232; Schlaefer, 1981, 642-643; Groarke, 1988, 1543; Pyle, 2001, 119.

134 Sapiro, 1986, 663-65. 
dictatorships demonstrates its illogical use. Should the possibility of arbitrary trials be the main concern behind the exception, different countries should be treated differently in extradition treaties. This idea will be discussed in more detail, especially in Chapter 5, Section 5.2.5.

Second, the aim of the political offence exemption was to lessen international tensions. According to Kirchheimer, the consistent implementation of the POE protects courts from political pressure. ${ }^{135}$ Denying extradition for all political offenders ideally prevents situations that force the state of refuge to take a stand on the internal political conflicts of the requesting state. The aim for political neutrality hides an amount of cynicism, as it is partly based on the idea that the political offender might at some point become part of a legitimate government in the state she or he has targeted. ${ }^{136}$

Third, the POE has also been justified by the idea that political crimes lack some of the elements of ordinary crimes. ${ }^{137}$ Specifically, pure political crimes can be seen to lack malice, which is one of the essential elements of an ordinary crime. ${ }^{138}$ Thus, the lack of personal motivation would abolish the criminal nature of the act. As discussed earlier, some view political crimes as acts deserving glorification. ${ }^{139}$

The aim of a political crime is to change the political situation and injure the public rights of an existing government. The motivations of the perpetrator are not private but public concerns. Further, as they target the government, (pure) political crimes do not violate the private rights of individuals. However, as Antje Petersen and Manuel R. García-Mora have argued, this is only applicable to 'pure' political offences, such as treason, sedition and espionage, as they generally are victimless because they only target governmental structures. ${ }^{140}$

Fourth, according to some, political offenders should be exempt from extradition, as political offences do not cause a threat to the legal order globally. As they are motivated by local conflicts, their implications are also limited to a local setting. This idea, however, nowadays seems outdated because states are highly interconnected and because the modern terrorist threat cannot be understood as targeting only one specific government. Modern means of communications and transportation enable some political crimes to become threats to the entire international public order. States share an interest in suppressing these types of offences, especially those that target like-minded governments. ${ }^{141}$

Whether the political offence exemption, in fact, serves the presented four purposes remains debated. The political offence exception is based on rather

135 Kirchheimer, 1961, 384.

136 See e.g. Deere, 1933, 249; Vallée, 1976, 772; Van den Wijngaert, 1980, 2-3, 204-205; Petersen, 1992, 776.

137 See e.g. Vallée, 1976, 772.

138 Clark, 1909, 97-98; Garcia-Mora, 1962, 1237.

139 Clark, 1909, 97; Van den Wijngaert, 1980, 29.

140 Petersen, 1992, 776.

141 Kulman, 1986, 772; Sapiro, 1986, 664. 
complicated political considerations. On the one hand, it aims at protecting individuals against unfair trials and providing them with the opportunity to rise against tyrannical regimes. On the other hand, this cannot be done at the expense of the international public order. ${ }^{142}$ For instance, Sapiro has been critical of the possibility of the exception to actually serve these outspoken goals. She has supported the right of the individuals to promote political change, but simultaneously underlined the importance of extradition serving its function by not making "culpability to disappear miraculously at the border." 143

The most common and perhaps the most substantial critique of the POE has been expressed by Ivor and Clive Stanbrook who have called the POE as a legal minefield. ${ }^{144}$ They, along with Christine van den Wijngaert and David M. Lieberman, have pointed out that on the one hand, the exemption might end up sheltering those who have committed severe crimes, protected due to their political motivation, and on the other, it may fail to protect those who may face an unfair trial for a common offence if extradited. This reflects the reality of the political offence exemption; it is a balancing act between public order and safety on the one hand, and the human rights of both the offenders as well as their victims on the other. ${ }^{145}$

It is clear that the evaluation of a political crime will never be free from political considerations. There are several reasons for which a state might either deny or accept an extradition request. It can have a concern for preserving the human rights of the offender; it may wish to confirm its dedication to certain ideals or values, or it can act on the basis of its own political interests or the interests of a specific group in power. The POE is weak even in protecting 'pure' political offenders. When both the requesting state and the asylum state have similar political views or converging interests, extradition might still be granted regardless of the nature of the crime. ${ }^{146}$

In addition to the POE itself, scholars have criticised the scope of the attentat clause excluding from the protection those targeting heads of state. The clause seems outdated as it only protects a limited category of people. Then again, the clause is also too wide when it applies to all cases of attacks on heads of state, even those of 'tyrannicide,' where the human rights of the citizens have been seriously violated by a tyrant. Moreover, it has been noted, heads of state, or tyrants themselves, if overthrown, could still be protected by the political offence exception and thus not be made responsible for crimes against their subordinates. ${ }^{147}$

142 Van den Wijngaert, 1980, IX.

143 Sapiro, 1986, 662.

144 Stanbrook and Stanbrook, 2000, 5.

145 Van den Wijngaert, 1980, 19; Gilbert, 1991, 130; Lieberman, 2007, 182; Oehmichen, $2009,21$.

146 Gilbert, 1985, 703.

147 Deere, 1933, 253; García-Mora, 1956, 84-85; Van den Wijngaert, 1980, 135-136; Stanbrook and Stanbrook, 2000, 82 . 


\section{Rise and decline of romantic liberalism}

The attentat clause has also been criticised for a lack of internal logic. If heads of state cannot be assassinated, perhaps other political leaders can? ${ }^{148}$ Or lower level public servants? ${ }^{149}$ And if some murders, even if not assassinations, can be seen as political crimes, why couldn't stealing money for running a political party be a political crime as well? "If political murder, why not political theft?" 150 García-Mora has argued that the possibility to consider some murders political is not useful in "free societies" that respect human rights norms. In such societies, no justification for any uses of violence exists. However, in cases where the extradition request is done by a 'tyrannical government,' it does not make sense to apply the attentat clause. ${ }^{151}$ For this reason, he has suggested that the cases should be evaluated individually, and not categorically deny the protection of the POE for all attentats. ${ }^{152}$

This position is of sound logic, but its application is problematic. First, if the aim of the POE is to protect one nation from meddling in another one's internal affairs, labelling the other state's government 'tyrannical' will hardly serve this purpose. Second, if the task of applying the POE is in the hands of the courts, as it is for instance in the US, this idea would force the courts to make a decision whether another country's government is 'tyrannical.'

Furthermore, the attentat clause seems to be in conflict with the original purpose of the political offence exception. An assassination of a head of state is a highly political act, and in many cases the most efficient means to ignite political change. Due to the political nature of attentats, the Swiss Federal Tribunal and the Italian Court of Appeal of Turin have, for instance, exempted assassinations from extradition. ${ }^{153}$ British law has, in fact, considered attacks against a sovereign in power as treason, ${ }^{154}$ the ultimate political offence. As a consequence, the attentat clause was not added to the UK Extradition Act of $1870 .{ }^{155}$ For this reason, the UK, amongst other signatories, made a reservation to the 1957

148 Sometimes the attentat clause has been interpreted more widely, for instance so that it also covers diplomatic representatives. Stanbrook and Stanbrook, 2000, 82.

149 García-Mora, 1956, 83.

150 Following this question, the speaker, Coudert, at the Annual Meeting of the American Society of International Law in 1909 described a case where a forger tried to invoke the political offence exception with no success. "Indeed, a man who had forged a will to get a succession, fled to Switzerland and when his extradition was demanded by Russia (1873), claimed that he had stolen the money to give it to a revolutionary society; but even Swiss sense of humor was aroused, and his defence was held insufficient." Coudert, 1909, 131. As pointed out elsewhere in this study, murders are by no means the only crimes that have qualified as political offences for the purposes of the exception and, indeed, these crimes have also included financial crimes.

151 García-Mora, 1956, 84-85.

152 García-Mora, 1956, 86.

153 García-Mora, 1956, 83-84; Van den Wijngaert, 1980, 136-137; Sapiro, 1986, 677.

154 See Treason Act 1351 c. 2 (Regnal. 25 Edw 3 Stat 5).

155 Deere, 1933, 253; Pyle, 2001, 91, 108. 
European Convention on Extradition, enabling it to regard assassinations as political offences. ${ }^{156}$

The main problem with the attentat clause is that it is a one-size-fits-all type of solution. It does not allow the courts to consider the motive or the target of the crime. If applied, it, in the classic example, would categorically exclude the assassin of a latter-day Hitler from the scope of the protection of the POE. ${ }^{157}$

\subsection{The anarchist threat at the turn of the 20th century}

\subsubsection{Crime against the whole humankind}

In the last decades of the 19th century, anarchist terrorism became a major challenge to the POE. In the course of the 1890 s, 60 people were killed and some 200 wounded in incidents around Europe that were claimed to have been organised by anarchists. ${ }^{158}$ The US also felt the anarchist threat within its borders, as President McKinley was killed by an anarchist in 1901. ${ }^{159}$

In reaction, his successor, Theodore Roosevelt, declared: "Anarchism is a crime against the whole human race and all mankind should band against anarchist thought." The president urged that the anarchist speeches, writings and meetings of its supporters be treated as seditious and that their activities be constricted. All anarchists who already were in the country should be deported. The president drew a parallel between anarchism and piracy. Like piracy, it should be covered by international law. ${ }^{160}$ This rhetoric is close to today's antiterrorist rhetoric. According to Richard Bach Jensen, "It is very little exaggeration to claim that anarchism was the terrorism of the era between the year 1878 and 1934. In the public mind, however erroneously, anarchism and anarchists became synonymous with terrorism and terrorist." 161

Many countries were dealing with their own anarchist problems. Turkey was confronted by the Armenian nationalist movements in the 1880s and 1890s. Greece, Bulgaria and Serbia were the areas of operations of the Inner Macedonian Revolutionary Organisation (IMRO). Italy was suffering from the fact that a large part of the attackers were of Italian background, ${ }^{162}$ including Luigi Lucheni, the murderer of Empress Elisabeth of Austria in $1898 .{ }^{163}$

156 Stanbrook and Stanbrook, 2000, 82.

157 Pyle, 2001, 185.

158 Deflem, 2002. See Liang, 1992, 157, for a list of anarchist incidents in the late 19th century.

159 See e.g. Liang, 1992, 168.

160 Theodore Roosevelt (1858-1919) stated this in 1901 about anarchists. Cited in Tuchman, $1980,107$.

161 Jensen, 2014, 1, italics orig. See for the development of the anarchist movement in Europe and the emergence of anarchist terrorism in the late 19th century Jensen, 2014, 8-36.

162 Tamburini, 1997, 230; Tamburini, 2000, 45.

163 The implications of this murder are discussed in more detail later. 
Russia witnessed the capability of an anarchist plot in 1881 when Tsar Alexander II was murdered. The plan of the establishment of the 'Anarchist' or 'Black International' was a result of the gathering of a group that openly praised the assassination of the tsar and looked to Narodnaya Volya as a model. The anarchist operations of the time were based on individual action or acts executed by small cells of radicals. The fact that the operations were not controlled by a central organ made the suppression and prevention particularly difficult for the police. ${ }^{164}$

The claimed existence of an anarchist conspiracy suited the press well, which got more sensational headlines and, also above all, the police and the government that used it for the restrictions of civil liberties, the freedom of the press and the rights of association. ${ }^{165}$ Some states made attempts to rule anarchist deeds "against all social organisation" out of the scope of protection of the POE by depoliticising the acts. The purpose was to facilitate extraditions and police cooperation.

At first, the means to fight anarchist terrorism were sought for at the national level, but it soon became evident that international cooperation would be required in order to succeed in the suppression. ${ }^{166}$ Anarchists were an 'easy' enemy, as they aimed at harming the society, in addition to the particular government they attacked. For this reason, all states had an interest in capturing anarchists and not granting them political asylum. ${ }^{167}$ Governments were divided in two in their views of the way they thought anarchist terrorism should be encountered. Others considered repression as the best alternative for controlling anarchists. In contrast, other governments saw that repression actually laid the perfect breeding ground for anarchist terrorism. ${ }^{168}$

\subsubsection{A world without rules: a political goal}

Even if anarchism was often linked with terrorism it is not a terrorist philosophy by nature. Terrorism is a tactic used by some anarchists, but it is not necessitated by the social philosophy of anarchism. ${ }^{169}$ Anarchists are often classified into two types: "the philosophical and the fighting anarchists, one believing in the attainment of anarchy by the peaceful process of evolution and the other by the employment of force and revolution."170

There are differences in the way the action (propaganda by the deed) and the more passive ideology (propaganda by the word) have been emphasised in

164 Hoffman, 1998, 19.

165 Tamburini, 2000, 45.

166 Jensen, 1981.

167 Deere, 1933, 270.

168 Kinna, 2006, vol. 1, xxxv. See in more detail on the anarchist threat and the countering of anarchism Jensen, 2014.

169 Borum and Tilby, 2005, 202.

170 Charles Merriam, 1926, cited in Borum and Tilby, 2005, 204. 
different variations of anarchism. Some anarchists of the 19th century indeed could be seen as terrorists under most definitions, while others explicitly accentuated that they did not have any role in the acts of terrorism. Hence referring to all anarchists as terrorists is not equitable. Even Peter Kropotkin, one of the most important anarchist theoreticians, disassociated himself from the policy of propaganda by the deed. ${ }^{171}$ Additionally, at the end of the 19th century, the word 'terrorism' did not have the same sinister tone that it has nowadays. Some were indeed proud to be terrorists. ${ }^{172}$

Anarchism is first and foremost a political ideology, aiming at a world without rulers. ${ }^{173}$ Regardless, some have claimed that anarchist or nihilist violence that aims at destroying life or property lacks political aims. In comparison to 'textbook' political violence with more limited goals, anarchists try to destroy all governments. As politics is about how governance should be organised, contemporary writers especially often claimed that anarchism cannot be considered political.

French professor of criminal law Georges Vidal argued in 1916 that anarchists and nihilists did not have political motives, as they were not acting against a particular government but "against the very bases of social existence." ${ }^{174}$ An analogous position was taken by the International Institute in Geneva in 1892 where it was argued that "Crimes directed to uproot the fundamental social institutions, irrespective of national divisions or of any given political Constitution, or form of Government, are not to be considered as political crimes."175

A contemporary article "The Anarchist Beast" discussed the question of the political nature of anarchism. The article dealt with the prevailing situation in Britain, where anarchists were considered political criminals and were thus protected. The anonymous writer concluded that anarchists were not political criminals "in the ordinary sense." Their victims could be democratically elected and "they make no pretence of removing hereditary tyrants or of overthrowing oligarchies." "The anarchist is not a political assassin; he is merely a noxious beast." However, the writer did see the political nature of anarchism itself: "To what extent anarchist propaganda or anarchist associations should be tolerated in civilised communities is a more difficult problem [than how anarchist criminals should be dealt with]. The chief difficulty lies in the fact, horrible as it is to confess, that a war against anarchism is to a certain extent a war against opinion (though it be the opinion of brutes), and that the repression of an opinion is to a modern Government an almost insuperable task."176

171 Kinna, 2006, vol. 1, xxv.

172 Herrala and Puistola, 2006, 24.

173 One definition of anarchism is presented by Sheehan: "The etymology of the word [...] signals what is distinctive about anarchism: a rejection of the need for the centralised authority of the unitary state, the only form of government most of us have ever experienced." Sheehan, 2003.

174 Vidal, Georges: Cours de droit criminel et de science penitentiare, Cinquieme edition, 1916, 112. Cited in Ferrari, 1920, 310.

175 Coudert, 1909, 133, italics orig. See also Jensen, 2014, 1.

176 Published in Kinna, 2006, vol. 2, 185-88. 
A well-known German scholar of law and politics, Carl Schmitt, writing in 1932, was of the opinion that only those parties that did not aim at subverting the state could be given the right to compete for parliamentary and governmental power. This meant excluding extremists from both political sides from the sphere of open politics. ${ }^{177}$ The idea that anarchist acts should be excluded from the POE seems to reflect a related line of thought: the anarchists aimed at destroying the political structures themselves, and thus they could be considered non-political. Schmitt wrote in 1932 that "The equation state = politics becomes erroneous and deceptive at exactly the moment when state and society penetrate each other. [... Heretofore ostensibly neutral domains - religion, culture, education, the economy - then cease to be neutral in the sense that they do not pertain to state and to politics." 178 However, in the 19th century, a strong distinction between state and society as well as between the political and the social was typically made. Fields such as religion, culture, economics, law and science were seen as antitheses to the political. ${ }^{179}$ In contrast, Robert Ferrari, a contemporary scholar did consider anarchists and nihilists as political offenders and saw that they should be excluded from extraditions as such. ${ }^{180}$

\subsubsection{The depoliticisation of anarchism in 1898}

The emergence of an international anarchist threat proved the political offence exception problematic. It provided for anarchists to find safe havens within Europe. One of the key states that sheltered anarchists was England. England held on to its role as a safe haven so strong that it had prevented the organisation of international conferences and joint actions against nihilists and anarchists in 1881 and $1893 .{ }^{181}$ However, as the amount of violence grew, pressure from other states also intensified.

According to Christopher H. Pyle, "It had been politically easy for the United States and the United Kingdom, the Low Countries, and France not to surrender failed liberals or failed monarchists; it was much more difficult to shelter failed assassins, dictators or robbers. [...] As political violence moved away from disciplined military and paramilitary revolts and toward random acts of indiscriminate killing, the political offence exception became harder to justify, except as an expression of the political neutrality of a country that still was not ready to accept sustained international responsibilities." ${ }^{182}$

Before the anarchist wave, the revolutionaries of the mid-19th century had been members of the middle class, challenging the authority of corrupt nobility. In contrast, anarchists and communists were attacking the middle class

177 See Schwab, 1996, 14.

178 Schmitt, 1996 (1932), 22.

179 Schmitt, 1996 (1932), 23.

180 Ferrari, 1920, 310.

181 Jensen, 1981, 326-27.

182 Pyle, 2001, 105. 
itself, which was not easy to tolerate for liberals. The middle class necessitated political stability provided by a government, and did not wish to undermine all authority. ${ }^{183}$

The change in Britain's position was visible in the In re Meunier case of 1890. In this case, the anarchist nature of the act was considered a factor that excluded the fugitive from the protection of the POE and made granting his extradition possible. France wanted Meunier from Britain for committing an 'anarchist' bomb attack which had killed two people. Two criteria were used to establish that the event did not fall into the category of the political offence exception. The first one followed the traditional application of the incidence test: there was no ongoing political struggle in France. The second was a novelty: the anarchist nature of the act. ${ }^{184}$

The court declared, following the logic of aforementioned contemporaries, that as anarchism was not trying to create a new government, it was the enemy of all governments and as such, could not fall within the exception. One of the members of the court argued that

[I]n order to constitute an offence of a political character, there must be two or more parties in the State, each seeking to impose the Government of their own choice on the other, and that, if the offence is committed by one side or the other in pursuance of that object, it is a political offence, otherwise not. [...] [T] he party with whom the accused is identified by the evidence, and by his own voluntary statement, namely, the party of anarchy, is the enemy of all Governments. Their efforts are directed primarily against the general body of citizens. They may, secondarily and incidentally, commit offences against some particular Government; but anarchist offences are mainly directed against private citizens. ${ }^{185}$

In its decision, the Meunier court focused more on the ideology of anarchists, rather than on the indiscriminate nature of their crimes. According to Christopher H. Pyle, "This focus, which essentially opened the anarchists to extradition for their beliefs, expressed the rising conservatism of traditionally liberal governments at the turn of the twentieth century." ${ }^{186}$ For this reason, it can be seen that the Meunier case represented a novel usage of the depoliticisation strategy against crimes of terroristic nature, in addition to the attentat clause. ${ }^{187}$ However, the Meunier decision cannot be interpreted as a sign of a consistent new court practice

183 Pyle, 2001, 106.

184 In re Meunier, 2 Q. B. D. 1894. See e.g. García-Mora, 1956, 87; Green, 1962, 330; Epps, 1979, 65; Van den Wijngaert, 1980, 111; Sofaer, 1986, 127; Gilmore, 1992, 705; and Noone and Alexander, 1997, 64-65, for details on the case and decision.

185 In re Meunier, 2 Q. B. D. 1894, cited in Coudert, 1909, 132, and Hannay, 1980, 390.

186 Pyle, 2001, 108.

187 It is of course debatable whether the assassination of a head of state should be considered terroristic in nature. 
emerging. According to Geoffrey Gilbert, the decision was mostly related to the fact that Meunier's political ideas were not considered acceptable in Britain. ${ }^{188}$

Two years after the In re Meunier case, in 1892 the International Institute in Geneva, which had wished to exclude all violent crimes from the protection of the POE, decided that anarchist deeds should be excluded from the scope of the exception. ${ }^{189}$

In 1893, anarchist bombings in Paris and Barcelona sparked a discussion on the need of an international police collaboration organisation. The idea was introduced by Spain, France and England. Also, Austria and Germany showed interest but were concerned about domestic political repercussions of such a decision. What slowed down the process was the lack of a general definition and shared understanding of anarchism. ${ }^{190}$

Finally, in 1898, the murder of Empress Elisabeth of Austria caused, as Richard Bach Jensen has summed it, a "wave of hysteria" across Europe. ${ }^{191}$ The Austrian foreign minister Count Goluchowsky referred to anarchists as "wild beasts without nationality," who were a menace "not only to sovereign rulers but to all persons and all private property." 192 In 1898 it was also predicted that the next target for an anarchist attack would be the King of Italy. ${ }^{193}$ As a reaction to the situation, Italy called for a European-wide Anti-Anarchist Conference. ${ }^{194}$ The conference was one of the attempts to fight the anarchist threat and is discussed here with the aim to describe the depoliticisation strategy that was chosen by the conference. ${ }^{195}$

The secretly held 'International Conference of Rome for the Social Defence Against Anarchists' was opened on November 24, 1898, and it was attended by the representatives of 21 European countries. ${ }^{196}$ The secrecy was so total that some historians almost a century later have claimed that the conference was never organised. ${ }^{197}$

188 Gilbert, 1991, 129.

189 Coudert, 1909, 133.

190 Liang, 1992, 161.

191 Jensen, 1981, 325.

192 Cited in Liang, 1992, 160.

193 Jensen, 1981, 325; Tamburini, 1997, 230.

194 Jensen, 1981, 326; Liang, 1992, 161. The British Government also had been pressured to act by France and Russia, where the heads of state had recently been assassinated by individuals linked to London. Collyer, 2005, 287.

195 See for more details on the Rome conference Jensen, 2014, 131-84.

196 Germany, Austria-Hungary, Belgium, Bulgaria, Denmark, Spain, France, Great Britain, Greece, Italy, the Principality of Monaco, Montenegro, the Netherlands, Portugal, Romania, Russia, Serbia, Sweden and Norway, Switzerland, and Turkey. PROPOSITIONS arretées par la Conférence internationale réunie à Rome sur l'initiative du Gouvernement Italien en vue d'étudier et d'établir les moyens les plus efficacies pour combattre la propaganda anarchique et soumises par elle à l'appreciation des Gouvernements qui s'y trouvaient représentés. Rome, 21 December 1898. Published in Kinna, 2006, 328-329. (Henceforth referred to as the final propositions of the AAC of Rome, 1898.)

197 Tamburini, 1997, 227-28; Jensen, 1981, 323. 
The objective of the conference was to devise and to put into practice a common defence system against anarchist acts and against the propagation of anarchist theories. ${ }^{198}$ The participants were free to adopt any of the decisions and with any reservations they saw necessary. ${ }^{199}$ The formal depoliticisation of anarchism led to a comprehensive participation, but only a small number of countries took action based on the provisions of the conference. ${ }^{200}$ As Richard Bach Jensen has stated: "national self-interests and rivalries edged out international concerns."201

The conference defined anarchist acts in the following manner: "II. Est considéré comme acte anarchique, au point de vue des resolutions de la Conférence, tout acte ayant pour but la destruction, par des moyens violents, de toute organization sociale. Est repute anarchiste celui qui commet un acte anarchique au sens indiqué ci-dessus." ${ }^{202}$ In the final propositions of the conference, anarchism was formally depoliticised with one simple paragraph: "I. La Conférence estime que l'anarchisme n'a rien de commun avec la politique et qu'il ne saurait, en aucun cas, être considéré comme une doctrine politique." ${ }^{203}$ Anarchism being usually understood as a political doctrine, this paragraph contradicts with most of the definitions of anarchism. ${ }^{204}$ By separating anarchism from politics, the conference depoliticised the ideology and criminalised it.

The conference aimed at removing anarchist safe havens by suggesting that an anarchist should be extradited subject to the principle of dual criminality, that is only if anarchism was considered a crime also in the receiving country. It also wanted to restrict the use of the political offence exception by stating that for the purposes of extradition, anarchist acts were not to be considered political but criminal acts.

Even if anarchism was depoliticised for the purposes of extradition, the conference also dealt with it as a political problem, and thus used a strategy which is referred to as 'repoliticisation' in this study. The aim of the conference was not only to bring to justice those responsible for violent anarchist acts but also to prevent the anarchist ideology from spreading. This was to be achieved by restricting their freedom of speech and, for instance, demanding that trial documents considering anarchist acts should be kept secret from the public, that reports on anarchism should be limited in the press, that the diffusion of anarchist thought should be constrained by seizing all material that would be banned at a later stage and finally that imprisoned anarchists should be isolated from other inmates. ${ }^{205}$

The conference was criticised by contemporaries. Socialists feared for strict measures against their thought. The anarchist critics wanted attention to be

198 The final propositions of the AAC of Rome, 1898.

199 Liang, 1992, 163.

200 Deflem, 2005; Tamburini, 1997, 253.

201 Jensen, 1981.

202 Paragraph II, the final propositions of the AAC of Rome, 1898.

203 The final propositions of the AAC of Rome, 1898. Translation by the author.

204 See Jansson, 2008, 28-36.

205 Jansson, 2008, 41-42. 
paid to the social conditions in Italy as the cause for the rise of anarchism. Characteristically, this critique was expressed and published abroad. ${ }^{206}$

The Anti-Anarchist Conference was balancing between criminalising anarchist thought and dealing with it as common crime. This rather strange balancing act has been typical to most de-/repoliticisation efforts of inherently political crimes. The depoliticisation of anarchism was perhaps an early effort to create an equilibrium between demands for more civil liberties, such as the freedom of speech on the one hand and the fight against anarchism on the other. The Anti-Anarchist Conference seemed to aim at merely fighting the most heinous anarchist crimes, but in fact, also wanted to suppress anarchist thought. The depoliticisation was done simultaneously to using apparently political measures, such as censorship, in the fight against the phenomenon. ${ }^{207}$ This paradoxical depoliticisation-repoliticisation of anarchism is analogous to the treatment of terrorism in modern days. This idea will be developed further in the scope of this study.

Because the aim of the conference so clearly was the curtailing of a specific political phenomenon, but the method was its depoliticisation, it is fair to come to Deflem's conclusion that "The fight against anarchism was evidently a matter of a decidedly political nature, especially because and when it included policies reaching beyond the control of criminal incidents inspired by anarchist motives."208

As a result of the propositions made by the conference, the attentat clause spread to most European extradition treaties. This changed the policies of e.g. Italy, which had held sympathies for tyrannicides for historical reasons. By World War I the attentat clause had become standard practice. The most important consequence of the conference was, however, the promotion of closer international cooperation and faster communication between the police forces in Europe. ${ }^{209}$

Considerations of political advantage played a key role in the outcome of the conference. Francesco Tamburini has argued that the several cases where a head of a state was murdered or his life was menaced by an anarchist between 1898 and 1914 have symbolised the failure of the Rome conference. ${ }^{210}$ In 1900, King Umberto I of Italy was murdered, which hastened the drawing of anti-anarchist legislation. ${ }^{211}$ According to Tamburini, the lack of success was both on the diplomatic and the practical level. ${ }^{212}$ The fact that England did not sign the final propositions was at least a practical failure since many of the anarchists dwelled in the safe and liberal Britain. ${ }^{213}$ Thus, the conference was at the same time a failure

206 Tamburini, 1997, 234-35.

207 Jansson, 2008, 42-43.

208 Deflem, 2005.

209 Jensen, 2014, 171. See also 174-80.

210 Tamburini, 1997, 261.

211 Liang, 1992, 171-72.

212 Tamburini, 2000, 48.

213 Di Paola, 2007, 190. 
and a success. The later developments suggest that neither view provides a comprehensive picture of the totality.

The exclusion of anarchist acts from the scope of the POE, as recommended by the Anti-Anarchist Conference, never became widely used, even if some of the proposed changes were indeed implemented in conventions. These treaties include the Pan American Treaty of 1902, ${ }^{214}$ which was never brought into force; ${ }^{215}$ the Colombia-Panama treaty of $1927 ; 216$ and the Brazil-Bolivia treaty from 1938, ${ }^{217}$ which excluded from the scope of the POE acts that constituted primarily offences of common criminal law $^{218}$ as well as acts of anarchism. ${ }^{219}$

Only much later did one of the US extradition treaties limit the POE in this regard. Article 5 of the US-Brazil treaty of 1961 states that "Criminal acts which constitute clear manifestations of anarchism or envisage the overthrow of the bases of all political organisations will not be classed as political crimes or offences." ${ }^{220}$ Brazil used this clause in at least two other extradition treaties; however, it did not add it to all of its treaties. ${ }^{221}$

Even if the changes were not widely applied, it seems that most Western states eventually took the depoliticisation of anarchism seriously. Writing 11 years after the Anti-Anarchist Conference, Coudert made a strong statement:

It is generally admitted that anarchistic crime does not fall within the category of political crime. All nations recognise the absolute necessity for some kind of government. Persons whose mental and moral deficiencies lead them to commit acts of violence with the motive of destroying organised society, in the name of a Utopian dream, and of reducing civilisation to the condition of a primeval horde, obtain no sympathy from the nations. ${ }^{222}$

214 Article 2, Treaty for the Extradition of Criminals and for the Protection against Anarchism. Second International Conference of American States, Doc No 330, 22 October 1901-31 January 1902.

215 American Journal of International Law, Introductory Comment, Supplement, 1935, 47.

216 "Los actos caracterizados como de anarquismo por las leyes de ambos Estados no serán considerados como delitos politicos." Article 4, Tratado de extradicíon, República de Colombia y República de Panama, 24 December 1927. See also García-Mora, 1956, 87.

217 Article 3, Tratado de extradição entre o Brasil e a Bolivia, 25 February 1938. See also García-Mora, 1956, 86.

218 "A alegação do fim ou motivo político não impedirá a extradição, se o fato constitue principalmente infração da lei penal comum." Article 3, Tratado de extradição entre o Brasil e a Bolivia, 25 February 1938. See also García-Mora, 1956, 86.

219 Não serão reputados delitos políticos os fatos delituosos que constituirem franca manifesta??o de anarquismo ou visarem subverter as bases de toda organização social. Article 3, Tratado de extradição entre o Brasil e a Bolivia, 25 February 1938. See also García-Mora, 1956, 86.

220 Article 5, Extradition Treaty and Additional Protocol between the United States of America and Brazil, 13 January 1961.

221 See e.g. Tratado de extradição entre o Brasil e a Bélgica, 6 May 1953; Tratado de extradição entre o Brasil e a República Italiana, 17 October 1989.

222 Coudert, 1909, 131. An interesting point to be drawn from Coudert's comment is the question of "mental deficiencies" he refers to. Where is the limit between madness and politics? How crazy must a political ideology be to represent madness instead of politics? 


\subsubsection{Why was anarchism depoliticised?}

The late 19th century witnessed immense socio-economic changes. The rise of Marxism/Communism "born of the alienation and exploitative conditions of 19th-century capitalism" 223 occurred at the same time Europe was already gliding towards a war, later to be known as the First World War, between 1914 and 1918.

Until this era, religion had provided the only justification for terrorism. During the 19th century, the authority of the monarch as the one who derived from God was questioned. With the rise of nationalism, new nation states were born. Radical political thought such as anarchism, nihilism and Marxism assumed a lot of importance, and anti-state terrorism rose. Terrorism transformed to a secular phenomenon. ${ }^{224}$

Historians widely accept the view that the rise of terrorism during the $1880 \mathrm{~s}$ and 1890s created insecurity and an interest in finding new measures to tackle the terrorist threat. ${ }^{225}$ Anarchism was perceived as an ideology that aimed at destroying the political, social and economic systems of the world. As the political systems of many European nation states were newly established, stability was vital for them. This is why the reaction to the anarchist threat was especially strict.

Nonetheless, the aims of the late 19th century anarchists were not extremely radical and uncompromising. Many were not after a revolution but merely wanted to get their voices heard. Further, many of the contemporaries not participating in the revolting agreed with the causes of the protesters. The protest was sometimes, however, expressed through extreme terrorist actions that were disapproved by most, even many anarchists. ${ }^{226}$ The anarchist movement eroded the romantic notions of the noble nature of revolutionaries that persisted in the 19th century. ${ }^{227}$

Anarchism ensued from the social conditions of the late 19th century. The officials did not understand it, and responded with inadequate legislative measures. The repression of anarchists by the police, together with the sad economic conditions, created an amount of hate that led up to even murders. The legislative measures reflected the fears of the leading class in Italy ${ }^{228}$ and presumably all over Europe.

As a result, the depoliticisation of anarchism can partly be explained by the shared will of the states that participated to the Anti-Anarchist Conference to obscure the underlying reasons, social inequalities, for this kind of radical political activity and to consider it as common criminality.

Another possible explanation for the depoliticisation of anarchism could have been the apprehension of a war among European states. An act of terrorism can

223 Hoffman, 1998, 17.

224 See e.g. Hoffman, 1998.

225 Kinna, 2006, vol. 1, xxxv.

226 Kinna, 2006, vol. 1, xxxviii.

227 Pyle, 2001, 106.

228 Tamburini, 2000, 44; Kinna, 2006, vol. 1, xxxviii. 
be used as a reason/excuse for war, as was witnessed later when Yugoslavian nationalist Gavrilo Princip killed Archduke Franz Ferdinand in Sarajevo in 1914. The act of a member of an extremist group (also called anarchist) was politicised $^{229}$ and led to the outbreak of World War I. Politicisation, in this case, means the fact that the act of one person was perceived as an act by the whole nation, in other words as a political act instead of a criminal act. Depoliticisation can, in contrast, be used to serve the opposite purpose. It can provide the states with the possibility to maintain peace, regardless of individual terrorist actions. Should the act have been depoliticised, it would have been considered a common crime, which would possibly not have fuelled the war.

Otto Kirchheimer made an interesting observation in 1961 with regard to how these isolated acts of violence were dealt with. While weight was given to improving collaboration in catching criminals committing isolated acts of violence, the POE was accepted as a means to protect actual revolutionaries participating in wider political movements, even if the first group was much less likely to create permanent change in society. However, according to Kirchheimer, this logic was sound in pre-1918 Europe. Serious revolts in the West had not occurred since the 1871 Paris Commune, but individual acts of violence were common. For this reason, international collaboration concentrated on two groups of political offenders: anarchists, considered as enemies of all social order, and other perpetrators of particularly brutal and atrocious acts. However, as Kirchheimer pointed out, "Obviously, enemies of any social order is a vague enough category to permit broadened interpretations at any time to match the fashion of the day." 230

\subsubsection{The 1937 convention}

Since the attempts of barring the anarchist movement that spread in the West the late 19 th to early 20 th centuries and before the boom in antiterrorist conventions and laws post-WWII, the most noteworthy attempt to tackle all terrorism, regardless of its political motives, was done by the League of Nations in 1937. The League of Nations created the world's first antiterrorism convention, known as the Convention for the Prevention and Punishment of Terrorism, ${ }^{231}$ as a reaction to the assassination of the French statesman Jean-Louis Barthou and King Alexander of Yugoslavia in Marseilles in 1934, organised by a group of Croatian nationalists. ${ }^{232}$ The extradition of one of the perpetrators who fled to Italy was denied by Mussolini's reign. The extradition would have been against

229 The Serbian government was aware of the objectives of the extremist group Princip belonged to, but it is not evident that the government would have been committed to war with Austria. See in more detail for the political background of the assassination e.g. Clark, 2012, 3-64.

230 Kirchheimer, 1961, 374-75.

231 League of Nations, 16 November 1937.

232 See e.g. Kirchheimer, 1961, 370; Bassiouni, 2001, 47; Jensen, 2014, 365. 
the country's interests in the Balkans, as Italy hoped to weaken the South Slav Federation. For this reason, a wide definition of political crime was applied and extradition denied based on the POE. Otto Kirchheimer has pointed out that the political motive was distant in this case: "[The decision] also ignored the fact that the Croat terrorists did not have sufficient political reasons to kill a French statesman and wound a French general." ${ }^{233}$ As this deed had no link to the anarchist movement, it demonstrated that terrorist acts could also be done by those other than anarchists. The convention made no reference to anarchism. ${ }^{234}$

The convention was signed by 24 states, but only India, which had not yet gained independence, ratified the convention before the Second World War began. ${ }^{235}$ During this period, the League of Nations was getting weaker and weaker after both Mussolini's Italy and Hitler's Germany had left the organisation. All in all, the diplomatic importance of the organisation had never even come close to, for instance, that of the modern United Nations.

The convention is of interest to the present study because of its rather modern take on terrorism. It defined terrorist acts as "criminal acts directed against a State and intended or calculated to create a state of terror in the minds of particular persons, or a group of persons of the general public," 236 including

1. Any wilful act causing death or grievous bodily harm or loss of liberty to:

a) Heads of States, persons exercising the prerogatives of the head of the State, their hereditary or designated successors; b) the wives or husbands of the above-mentioned persons; c) persons charged with public functions or holding public positions when the act is directed against them in their public capacity. 2. Wilful destruction of, or damage to, public property or property devoted to a public purpose belonging to or subject to the authority of another High Contracting Party. 3. Any wilful act calculated to endanger the lives of members of the public. 4. Any attempt to commit an offence falling within the foregoing provisions of the present article. 5. The manufacture, obtaining, possession, or supplying of arms, ammunition, explosives or harmful substances with a view to the commission in any country whatsoever of an offence falling within the present article. ${ }^{237}$

Further, also the conspiracy, incitement, participation and assistance to these acts were to be criminalised. ${ }^{238}$ Thus the convention's definition of terrorism covered

233 Kirchheimer, 1961, 372.

234 Jensen, 2014, 365.

235 Bassiouni, 2001, 47.

236 Article 1, League of Nations: Convention for the Prevention and Punishment of Terrorism, 16 November 1937.

237 Article 2, League of Nations: Convention for the Prevention and Punishment of Terrorism, 16 November 1937.

238 Article 3, League of Nations: Convention for the Prevention and Punishment of Terrorism, 16 November 1937. 
a wide variety of acts, including a wider scope for the traditional attentat clause. It also covered acts that only caused property damage as well as a variety of preparative acts.

The aim of the convention was to get all contracting states to create national terrorism legislation and to criminalise acts committed on their own territory if aimed against another contracting party. ${ }^{239}$ The defined crimes were to be deemed as extradition crimes in all existing and future extradition treaties. Should it have been ratified, the convention would have made illegal almost all violent means of opposition. However, the obligation regarding extradition was "subject to any conditions and limitations recognised by the law or the practice of the country to which application is made." This meant that the political offence exception would have remained applicable for terrorist crimes, should the requested state have seen it fit. ${ }^{240}$ As a result, the conference did not depoliticise terrorism or even aim at doing so, for the purpose of excluding it from the scope of the POE.

What is interesting and noteworthy is that the League of Nations convention did not mention political goals in its definition of terrorism. Instead of its motives, terrorism was defined by what it aimed at destroying. This is a rather modern definition, as present-day terrorism definitions often resemble it in this regard. However, the convention did not cover acts committed against the general population.

According to Ondřej Ditrych, with the convention "the terrorist was depoliticised into the 'enemy of the human race', to whom no protection should be provided abroad if he were to commit a 'political crime' (including assassination)." In the council debate, it was initially argued that terrorism never had political sense, but the French proposal underlined the need to repress "political crimes of international character." According to Ditrych, "Eventually, however, the depoliticised character of the perpetrators of terrorist acts as professional assassins, criminals, malefactors, common murderers, thieves, incendiaries and paid agents carrying out certain instructions (presumably given by the revisionist state) would become a dominant pattern of subjectification."241

Philip Jenkins has pointed to the political context in which the convention was made. In the 1930s, several regimes were such that they could be understood as dictatorships, for instance, Germany, Japan, Italy and the Soviet Union. When ratified, the convention would have made the opposition to these regimes terroristic. $^{242}$

239 Article 2, League of Nations: Convention for the Prevention and Punishment of Terrorism, 16 November 1937.

240 Article 8, League of Nations: Convention for the Prevention and Punishment of Terrorism, 16 November 1937.

241 Ditrych, 2013, 226.

242 Jenkins, 2003, 26. 


\subsection{Conclusion}

The 1800s witnessed the emergence of an ideal of a heroic political offender, fighting for liberty, democracy and nationalism. The POE grew out of a change in Western political thought. Political offenders, previously seen as the ultimate threat to the existence of the divine rule of governments, came to be viewed as heroic revolutionaries and possible future leaders of newborn nation states. It was no longer seen that subordinates of a state should also be subjugated. This idea is related to the origins of the concept of human rights.

The political offence exemption was designed to protect revolutionaries from unfair trials and severe punishments and to assist states in remaining somewhat neutral towards political changes in other states during an era of political turmoil. The protection of political criminals provided the states with more diplomatic flexibility in case revolutionaries managed to claim power and become diplomatic partners.

Soon after its creation, the exemption was challenged. First, it became clear that Western nations no longer considered assassins targeting heads of state as romantic and benevolent criminals deserving sanctuary and protection in neighbouring states after their brutal acts. This led to the creation of the attentat clause.

As the methods, means and goals of perpetrators of political violence have changed, the attentat clause now seems outdated. It protects a very limited group of people: symbolic leaders with political power. The viewpoint that heads of state deserve extra protection did not take into account the current terrorist tactics, where political violence has growingly targeted civilians.

The creation of the attentat clause, excluding these criminals from the protection of the POE, is a reactive strategy. The attentat clause was created only when it became obvious to states that their stability was undermined by individuals seeking to promote political change. More than an ideological choice, it thus was one of pragmatism. The same model was later repeatedly used when the POE proved to protect also the most brutal criminals.

The second challenge to the POE came from the rise of the anarchist threat at the end of the 19th century. Also, the anarchists typically targeted heads of state, but the threat they posed was unforeseen. The reaction to the anarchist threat proved to be rather problematic. Most extradition treaties were not modified as a result of the threat, even if this was considered highly important. However, some adjustments were attempted to improve intranation collaboration as demonstrated by the case of Meunier. Nonetheless, the end result seems to have been very limited.

The period of romantic liberalism was thus not wrecked by anarchists, even if the grounds of liberal views were shaken. It is possible that the political cost of seriously going after anarchists would have been too great, especially within Europe, which had other, more burning political controversies to deal with. The era where the political offender was seen as a hero fighting for liberty thus lived until the end of the Second World War. The war tainted the image of a heroic 
offender by the large-scale atrocities committed. However, the treatment of war criminals was separated from the treatment of other political criminals, ${ }^{243}$ and the liberal idea that other political offenders deserved protection persisted well into the 1960s.

In the following chapter, I concentrate on the tug of war between those who wished to limit the POE and those who still saw that there was a screaming need for the possibility to protect those who are motivated not by personal gain, but by higher, more noble causes.

243 For a long time, the POE also protected war criminals. See e.g. Extradition Treaty between the Government of the United States of America and the Government of the Swiss Confederation, 14 November 1990; Extradition Treaty between the Government of the United Kingdom of Great Britain and Northern Ireland and the Government of the United States of America, 31 March 2003, Article 4. For the purpose of this book, the discussion on the notion of war criminals as political offenders is left out. Since the idea of international crimes emerged after the Second World War, war criminals have been dealt with differently in comparison to other political criminals. 


\section{Taking the political out of the political 1960s-1980s}

\subsection{Terrorism challenges the political offence exception}

\subsubsection{Gradual changes in US extradition treaties 1960s-1970s}

After the end of the Second World War, Western states witnessed a number of cases where violent offenders managed to escape justice due to the application of the POE. However, this did not provoke immediate reactions. For instance, US extradition treaties remained largely unchanged during the 1960s and 1970s. Some new wordings emerged and some treaties started to limit the political offence exception, but typically in a modest and careful manner.

The US-Brazil extradition treaty of 1961 is an early example of a treaty that begun limiting the POE for the most serious types of offences. As discussed in Chapter 3, Section 3.2.3, it excluded anarchist acts from the protection of the POE. Additionally, it made an interesting addition to the typical formulations of extradition treaties, echoing the Swiss proportionality or preponderance test. According to the treaty, extradition could be allowed "if the crime or offence for which his extradition is requested is primarily an infraction of the ordinary penal law." Extradition in these cases was, however, subject to other types of protection: "In such case the delivery of the person being extradited will depend on an undertaking on the part of the requesting State that the political purpose or motive will not contribute toward making the penalty more severe."1

The Brazil treaty is very interesting in two ways. First, the application of the predominance test has typically been a part of judicial decision-making, but not of the written text in extradition treaties except for the US-Argentina treaty from 1972 which contained the following provision: "The allegation of a political motive or end shall not impede the extradition if the alleged offence constitutes primarily a common offence, in which case the requested Party may request that the requesting Party give assurance that the political motive or end will not contribute to the aggravation of the penalty."

1 Article 5, Extradition Treaty and Additional Protocol between the United States of America and Brazil, 13 January 1961. Italics added.

2 Article 7, Treaty on Extradition between the United States of America and the Republic of Argentina, 21 January 1972. Italics added. 
Second, as discussed, the exclusion of anarchist-like crimes in the US-Brazil treaty was never widely used in US extradition conventions. The principle was only applied by a US court much later in the Eain case in 1980 between the US and Israel, ${ }^{3}$ but, in that case, this consideration was not based on the text of the bilateral extradition treaty between the US and Israel. ${ }^{4}$

Since the 1960s the UN started to create new antiterrorism conventions. The contents these conventions were little by little incorporated into US extradition treaties. The first of these conventions was drawn in 1963. The Tokyo Convention, relating to certain acts committed onboard an aircraft, intended to cover gaps related to piracy left by the Geneva Convention by taking into account acts onboard aircrafts. ${ }^{5}$ The criminalisation of piracy had a long history, and, for instance, M. Cherif Bassiouni has called aircraft hijacking "piracy of the air." The creation of the Tokyo Convention brought a highly political issue onto the agenda of the international community. The acts covered by the convention were serious crimes, but simultaneously, they could be interpreted as political. ${ }^{6}$

Eventually, also the Tokyo Convention left gaps which the 1970 Hague and the 1971 Montreal Conventions were designed to cover. ${ }^{7}$ In 1970, the Hague Convention on the suppression of aeroplane hijackings ${ }^{8}$ made unlawful seizures of civilian aircrafts extraditable crimes. It was a reaction to the hijacking of four aeroplanes originally headed to New York in September 1970. The hijackers were part of the Palestinian commando group later known as Black September. The scope of the convention was left so wide that it not only covers politically motivated terrorism but also hijackings for other purposes, for instance for financial gain. ${ }^{9}$

The hijacking of 1970 has been identified as the first push for the movement that aimed to limit or destroy the political offence exception. The US and the Soviet Union worked together in aiming to deny protection to all hijackers, regardless of motives. West European states wanted, in turn, to limit the provisions to the idea of aut dedere aut judicare in hijacking cases. The wording in the Hague Convention seems to exclude all hijackers from protection, but it left room for the protection of future Kolczynskis. ${ }^{10}$

The Hague Convention was the first international convention to be reflected in US bilateral extradition treaties. For example, the 1970 US-Spain extradition treaty prescribed that aircraft hijackings were to "be presumed to have a predominant character of a common crime when the consequences of the offence were

\footnotetext{
3 See in more detail Section 4.2.2.

4 Article 6, Israel International Extradition Treaty with the United States, 10 December 1962.

5 Lodge, 1981, 166.

6 Bassiouni, 1969, 218-219.

7 Lodge, 1981, 167.

8 Convention for the Suppression of Unlawful Seizure of Aircraft (The Hague Convention) UNTS 12325, 16 December 1970.

9 Cassese, 2006, 943.
}

10 Pyle, 2001, 186. 


\section{Taking the political out of the political}

or could have been grave. The fact that the offence has endangered the life or jeopardised the safety of the passengers or crew will be given special consideration in the determination of the gravity of such consequences." ${ }^{\prime 1}$ An almost identical limitation was provided in the 1971 United States treaty with Canada ${ }^{12}$ and the 1973 treaty between the United States and Italy. ${ }^{13}$ These thus depoliticised the treatment of aircraft hijackings by stating that these acts were to be considered as having "predominant character of a common crime," but only for the purposes of the application of the POE. In other words, they did not stipulate that aircraft hijackings were not political by nature.

The application of the Hague Convention soon proved problematic for the US. Due to the political conditions of the Cold War era, hijackers were in some instances seen as heroes, especially when they escaped socialist states. Hijacking was also used in matters that caused difficult political scenarios. For example, in some instances, Americans sought asylum abroad by hijacking planes. One of the most diplomatically complicated incidents was the 1975 case where France granted asylum to two African Americans who had made vague references to their involvement in the Black Panthers and relations with Hanoi when requesting for non-extradition for their crimes. ${ }^{14}$

In 1971 the UN concluded another treaty that was linked with terrorism onboard aircrafts, the Convention for the Suppression of Unlawful Acts Against the Safety of Civil Aviation (the Montreal Convention). ${ }^{15}$ The provisions of the Montreal Convention were reflected in the US-Canada treaty concluded the same year which excluded a number of violent crimes aboard an aircraft of a commercial airline and carrying passengers from the scope of the POE. ${ }^{16}$ The effect of the Montreal Convention was also visible in many other subsequent US extradition treaties ${ }^{17}$ but not all of them. ${ }^{18}$

Interestingly, the US-Canada treaty also excluded from the scope of the POE "(i) a kidnapping, murder or other assault against the life or physical integrity of

11 Article 5(A)(4), Spain International Extradition Treaty with the United States, 29 May 1970.

12 Article 4, Treaty on Extradition between the Government of Canada and the Government of the United States of America, 3 December 1971.

13 Article 7, Treaty on Extradition between the United States of America and Italy, 18 January 1973. The US-Italy treaty does not include the final sentence of the citation.

14 Pyle, 2001, 185.

15 Convention for the Suppression of Unlawful Acts Against the Safety of Civil Aviation (Montreal Convention) 974 UNTS 177, 23 September 1971.

16 Article 4, Treaty on Extradition between the Government of Canada and the Government of the United States of America, 3 December 1971.

17 See e.g. Article 4, Treaty on Extradition between the United States of America and the Republic of Paraguay, 24 May 1973, and, identically, Article 4, Treaty on Extradition and Cooperation in Penal Matters between the United States of America and the Oriental Republic of Uruguay, 6 April 1973; Article 7, Extradition Treaty between the United States of America and Finland, 11 June 1976.

18 This seems to have depended on the other party's participation in the conference; if the other party was a signatory of the Montreal Convention, the clause was included in the extradition treaty. 
a person to whom a Contracting Party has the duty according to international law to give special protection, or any attempt to commit such an offence with respect to any such person." 19 This was a provision that the UN only added in its Convention on the Prevention and Punishment of Crimes against Internationally Protected Persons, including Diplomatic Agents two years later, in 1973. ${ }^{20}$ Similar provisions were added to a number of US extradition treaties, prior and after the creation of the UN convention. ${ }^{21}$

In 1978, the Mexico-US treaty, amongst other similar treaties, created a completely new provision that made direct reference to UN conventions. It categorically excluded from the scope of the POE an "offence which the Contracting Parties may have the obligation to prosecute by reason of a multilateral international agreement." 22 Christopher H. Pyle has interpreted the signing of this treaty a departure of the US from its dedication to the political offence exception. ${ }^{23}$

Thus, it has been shown that during the early years of the 1970s, terrorist actions had already provoked a reaction that was visible in both UN conventions as well as US bilateral extradition treaties. However, in most extradition treaties the POE still remained practically untouched. Additionally, even if the US law would have allowed for antiterrorist conventions to be used as the basis of extradition, it never used this possibility. ${ }^{24}$

It can be argued that even if extradition treaties were not updated at a fast pace, the UN provisions should have affected the way in which the POE was interpreted. According to Geoffrey Gilbert, the crimes included in UN treaties were condemned by so many nations that they should never be protected by the POE. The application of the POE with regard to these crimes would contradict with an internationally agreed objective. ${ }^{25}$

\subsubsection{The new revolutionary wave and the US draft convention of 1972}

In the wake of the Second World War, a shared understanding of the necessity to globally condemn certain types of grave crimes emerged. The condemnation of specific criminal acts led to the creation of the aut dedere aut judicare principle

19 Article 4, Treaty on Extradition between the Government of Canada and the Government of the United States of America, 3 December 1971.

20 Convention on the Prevention and Punishment of Crimes against Internationally Protected Persons, including Diplomatic Agents, 1035 UNTS 167, 14 December 1973.

21 See e.g. Article 4, Treaty on Extradition between the United States of America and the Republic of Paraguay, 24 May 1973, and, identically, Article 4, Treaty on Extradition and Cooperation in Penal Matters between the United States of America and the Oriental Republic of Uruguay, 6 April 1973; Article 7, Extradition Treaty between the United States of America and Finland, 11 June 1976.

22 Article 5, Mexico International Extradition Treaty with the United States, 4 May 1978. See also Article 3, Treaty on Extradition and Mutual Assistance in Criminal Matters between the United States of America and the Republic of Turkey, 7 June 1979.

23 Pyle, 2001, 145.

24 Murphy, 1985, 43.

25 Gilbert, 1998, 296. 


\section{Taking the political out of the political}

establishing the duty to either extradite or prosecute certain international criminals. The protection offered to violent political criminals was limited for the first time since the attentat clause and the anarchist offence exceptions.

The decades after the Second World War saw a wave of revolutions and 'wars of liberation' in the developing countries as they, one by one, fought colonial regimes for their independence. These revolutionary movements typically utilised guerrilla-type action. Simultaneously, the rise of 'terroristic' violence growingly targeting members of the public within Western states provoked severe responses from political decision makers.

During the 1960s-1980s, terrorism became a major challenge to the application of the POE. Terrorists committed serious acts that fell into the category of extraditable crimes, but their mentality diverged from that of the common criminal. ${ }^{26}$ For this reason, some courts categorised them as political offenders, subject to the protection of the POE. These solutions were motivated by a multiplicity of factors including internal politics and the fear of retribution and coercion from either the terrorists themselves or from countries that supported their cause. For instance, some Arab states had put pressure on a number of Western states to prevent the extradition of PLO members. ${ }^{27}$

The date 22 July 1968 has sometimes been named the birthday of post-Second World War international terrorism. On this date, for the first time, a passenger aircraft was hijacked for political purposes. The hijacking was intended as a symbol and an instrument to create direct communications between the Palestinian terrorists and the Israeli government. ${ }^{28}$ Since that year, the relatively small number of active international terrorist groups rose fivefold over the next ten years. Many believed that international terrorism was the key to gain worldwide attention for their cause. ${ }^{29}$

In a world that was so used to protecting political offenders, dealing with revolutionaries using violence against civilians became a massive problem. As M. Cherif Bassiouni pointed out, in this kind of setting, the differentiation between 'common crimes' and 'political crimes' was no longer useful as the link between the criminal action and the aim sought by it had disappeared..$^{30}$

The push for the UN's first serious post-WWII attempt to abandon the patchwork approach and creating a comprehensive antiterrorism convention came from the United States in September 1972. The initiative was brought out three weeks after 11 Israeli hostages were killed in a terrorist attack at the Munich Summer Olympics. As a result of the attacks, President Richard Nixon established the Cabinet Committee to Combat Terrorism. ${ }^{31}$

26 Schaefer, 1981, 633.

27 Hannay, 1988, 116.

28 Hoffman, 1998, 67-69.

29 In 1968, there were 11 active international terrorist groups (3 ethno-nationalist/separatist and 8 radical leftist groups). Hoffman, 1998, 75 .

30 Bassiouni, 1969, 218.

31 Fields, 1988, 279. 
In the US draft convention, a terrorist was defined as "[a]ny person who unlawfully kills, causes serious bodily harm or kidnaps another person, attempts to commit such an act, or participates as an accomplice of a person who commits or attempts to commit any such act." The convention required the act being of international nature, and not committed by or against members of the armed forces or during military hostilities, and that it was "intended to damage the interests of or obtain concessions from a State or an international organisation." 32 The draft also contained the aut dedere aut judicare principle. ${ }^{33}$ Terrorism was thus understood as an act with a clear political goal.

What is telling of the international political atmosphere at the time is the preamble of the draft convention stating: "Measures to prevent international terrorism which endangers or takes innocent human lives or jeopardises fundamental freedoms and study of the underlying causes of those forms of terrorism and acts of violence which lie in misery, frustration, grievance and despair and which cause some people to sacrifice human lives, including their own, in an attempt to effect radical changes." 34 This demonstrates that terrorism was understood as a highly political phenomenon and that fighting it necessitated means that would not only try to stop the perpetrators but would also affect its root causes.

Even if these concerns were spelled out in the draft, the attempted convention also received strong opposition. A majority of UN member states wanted the organisation to condemn the Munich attacks, but many Arab, African and Asian states argued that "people who struggle to liberate themselves from foreign oppression and exploitation have the right to use all methods at their disposal, including force." 35

The reasoning behind the 'underlying causes' discourse can be linked to internal rules that Ditrych has called the 'two logics of exception.' According to this viewpoint, national liberation movements could never be seen as terroristic, because their causes were just, to the extent that they were defensive/restitutive and because those that participated in their activities had previously been the ones suffering. ${ }^{36}$ Additionally, according to many developing and socialist states, anticolonial violence was justified because state terrorism was performed by imperial powers. ${ }^{37}$ They also contended that the causes of terrorism had to be examined before acting against its effects. ${ }^{38}$

32 Article 1, Report of the Special Committee of the United Nations on International Terrorism, G.A.O.R., Supp. No. 28 (XXVII); United States' Draft Convention for the Prevention and Punishment of Certain Acts of International Terrorism. UN Doc. A/C.6/L850, 25 September 1972.

33 Article 3, US Draft Convention for the Prevention and Punishment of Terrorism Acts, 25 September 1972.

34 US Draft Convention for Prevention and Punishment of Terrorism Acts, 25 September 1972.

35 Schaefer, 1981, 633; Schmid, 1984, 100; Hoffman, 1998, 31.

36 Ditrych, 2013, 228.

37 Saul, 2006, 2.

38 Hannay, 1980, 381. 


\section{Taking the political out of the political}

First World countries, in turn, saw that the motives should have been considered irrelevant in the evaluation of the crimes, as non-state terrorism used violent means that went beyond the conventional limits of violence. This type of violence could never be legitimate, regardless of the causes. "because [it] represent [s] violence outside of institutions that constitute 'the very nature of our civilisation'." 39 For instance, the United States argued that an international consensus should have existed with regard to protecting civilian lives and the international order from anarchy, ignoring the possible political apologia for such behaviour. ${ }^{40}$

As a direct reaction to the Munich events of 1972 and the attack at the Lod airport near Tel Aviv that had taken place earlier in the same year, ${ }^{41}$ the 27 th session of the UN General Assembly dealt with terrorism under a headline copied from the aforementioned preamble of the US draft convention. ${ }^{42}$ The UN Secretariat had recently completed a study on terrorism, underlining the limits to the legal and moral justifications of the use of force in all human conflicts. ${ }^{43}$

In discussing the nature of terrorism, the UN study suggested that terroristic methods could be used both for political as well as criminal purposes. For this reason, "It seems difficult to delimit a legal topic on the basis of motives, which often lie deep in the minds of men." ${ }^{44}$ A similar idea later formed the basis of the depoliticisation of terrorism.

The study also argued that the "subject of international terrorism has, as the Secretary-General has already emphasised, nothing to do with the question of when the use of force is legitimate in international life." However, the limit of legitimate violence remained blurred. According to the study, national liberation movements "are not and cannot be affected" by the findings of the study. Further, "But even when the use of force is legally and morally justified, there are some means, as in every form of human conflict, which must not be used; the legitimacy of a cause does not in itself legitimise the use of certain forms of violence, especially against the innocent." 45

According to the study, there was a difference between international terrorism and "revolutionary mass movements, which are directly aimed at, and capable of,

39 Ditrych, 2013, 228.

40 Schaefer, 1981, 636.

41 Norton Moore, 1988, 437; Cassese, 1989, 7.

42 2114th plenary meeting, 18 December 1972.

43 UN Secretariat study: "Measures to Prevent International Terrorism Which Endangers or Takes Innocent Human Lives or Jeopardises Fundamental Freedoms, and Study of the Underlying Causes of Those Forms of Terrorism and Acts of Violence Which Lie in Misery, Frustration, Grievance and Despair and Which Cause Some People to Sacrifice Human Lives, Including Their Own, in an Attempt to Effect Radical Changes." Study prepared by the Secretariat in accordance with the decision taken by the Sixth Committee at its 1314th meeting, on 27 September 1972, UN Doc. A/C.6/418, 2 November 1972. Cited in Norton Moore, 1988, 439.

44 Chapter II (I), Measures to Prevent International Terrorism, UN Doc. A/C.6/418, 2 November 1972.

45 Saul, 2006, 10, 22. 
effecting radical changes in society, involving changes of conduct and attitude on the part of large numbers of people." In contrast, according to the study, "The terrorist act, on the other hand, even if its main purpose is to draw attention to a political cause or situation, has as its immediate aim something comparatively limited, although important, such as the acquisition of funds, the liberation of prisoners, the spread of general terror, the demonstration of the impotence of Government authorities, or the provocation of ill-judged measures of repression which will alienate public opinion. Thus the terrorist act usually lacks any immediate possibility of achieving its proclaimed ultimate purpose." 46

This rationale seems to relate to the reasoning behind the so-called incidence test in the application of the POE. According to this view, a revolutionary movement had the means and the possibility of making a change, whereas a terrorist actor did not have popular support. This separation is highly problematic because it merely suggests that the acquisition of power turns a terrorist movement into a more 'legitimate' revolutionary movement. Additionally, this separation proved to be problematic in hindsight, as, for instance, the Provisional Irish Republican Army (PIRA) was a highly organised paramilitary movement, but still, it was considered a terroristic organisation by the United Kingdom. ${ }^{47}$

There was a clear shift between the focus of the UN study which condemned violence in clear words and the final General Assembly session conclusions. The underlining of the importance of international legal action against terrorists changed to a lengthy study of the causes that provoke terrorism. ${ }^{48}$

\subsubsection{Politics overrule legal concerns 1970s-1980s}

The UN attempts to unite against terrorism mostly failed during the 1970s and 1980s. ${ }^{49}$ Creating an extensive definition of international terrorism proved unfeasible, as the member states' views on what terrorism was varied. This was due to disagreements concerning politically motivated violence between the West and the 'Third World' and Communist states. States disagreed on issues such as who was an innocent victim; how the actor's motivation could affect the legal consequences that fell upon him; and the concepts of national liberation, colonisation and occupation. Western states aimed at excluding acts committed by states from the definition of terrorism, while others wanted to include these..$^{50}$ Western states thought that the aim of 'Third World' states was to hinder the legislative action against terrorism, thus making it practically impossible to universally ban terrorism in a single convention. ${ }^{51}$

46 Chapter II (II), Measures to Prevent International Terrorism, UN Doc. A/C.6/418, 2 November 1972.

47 The PIRA is discussed in detail in Section 4.2.1.

48 See Chapter I (II), Measures to Prevent International Terrorism, UN Doc. A/C.6/418, 2 November 1972.

49 Hannay, 1980, 381.

50 See Bassiouni, 2001, 3.

51 DeSchutter, 1975, 378-379. 


\section{Taking the political out of the political}

Additionally, separate antiterrorism instruments were not effective, because they lacked ratifications ${ }^{52}$ and the means of enforcement. If a state that had ratified the Hague or Montreal Conventions refused to extradite a fugitive, no means existed to enforce the conventions. For instance, in the case of the Lockerbie bombings, Libya refused to extradite the accused. Regardless of the UN Security Council resolutions ${ }^{53}$ coercing action, it took over ten years for Libya to finally allow the extradition. ${ }^{54}$

Even if UN treaties attempted to make the extradition of certain types of offenders a rule rather than an exception, and thus distance it from political considerations, extradition was continuously used for political purposes. For instance, the Holder decision of 1972 demonstrates the effect political considerations had on legal matters. In this case, the United States sought the extradition of Holder who had, together with an accomplice, hijacked an aeroplane in the US and forced it to land in Paris. The hijackers had extorted half a million dollars from the airline and made vague references to known American radicals. According to Thomas Carbonneau, it was clear that the French court's decision to regard the offences as political was strongly affected by the government's criticism of the United States' policy in Vietnam. The political motivation of the offenders was fickle, and the gravity of the offences should have outweighed the political element in the act. In this case, the court did not attempt to remain neutral, but instead, it voiced the executive's political views. ${ }^{55}$

Comparably, in the case of Abu Daoud of 1977 courts also allowed political considerations to prevail over taking into account the extreme severity of the crime in question. Palestinian Liberation Organisation (PLO) member Daoud was wanted by West German and Israeli authorities for his participation in the organisation of the Munich Olympics massacre in 1972. This case did not involve the application of the POE, but France denied Daoud's extradition based on legal technicalities in the fear of an oil embargo or possible terrorist reprisals. ${ }^{56}$

France also denied the extradition of several Basque nationalist and separatist group ETA members. France had a strong dislike of Francoist Spain and simultaneously, there was a mass of Basque people within the French borders. ${ }^{57}$ As a result, France denied extradition of several offenders who, should they have been

52 Gilbert, 1998, 299.

53 UN Security Council Resolution on Libyan Arab Jamahiriya, S/RES/731, 21 January 1992; UN Security Council Resolution on Libyan Arab Jamahiriya, S/RES/748, 31 March 1992; UN Security Council Resolution on Libyan Arab Jamahiriya, S/RES/883, 11 November 1993; UN Security Council Resolution on the Lockerbie case, S/RES/1192, 27 August 1998.

54 Gilbert, 1998, 301; Emerson, 2004.

55 Carbonneau, 1983, 215.

56 See for a detailed evaluation of the case Carbonneau, 1977. See also Carbonneau, 1983, 216.

57 Carbonneau, 1983, 229; Gilbert, 1998, 304. 
West German nationals, most likely have been extradited. ${ }^{58}$ France's policy with regard to the ETA was named the sanctuary doctrine. Its aim was to keep terrorism outside the borders of the country. ${ }^{59}$

After the death of Franco, extradition requests from Spain started to produce diverse results. ${ }^{60}$ French courts growingly adopted the Swiss proportionality test when evaluating whether separatists could be protected by the POE. ${ }^{61}$ For instance, in the 1984 case that concerned three Basque separatists - Galdeano, Ramirez and Beiztegui - extradition was granted on account of the gravity of the crimes committed, depriving the offences of any political character. ${ }^{62}$

In 1986, France finally abandoned the policy of protecting ETA activists and started to collaborate with Spain by extraditing the fugitives. The following year, France ratified the European Convention on the Suppression of Terrorism of $1977,{ }^{63}$ which obliged it to extradite violent offenders. ${ }^{64}$ Interestingly, around the same time, a new French doctrine with regard to political offenders from Italy emerged. Upon his election in 1981, the first socialist president of France, Francois Mitterand, made a promise to deny the extradition of foreigners motivated by political factors, whereas his predecessor Valéry Giscard d'Estaing had had an opposite paradigm: he had been strongly in favour of collaborating with Italy in matters of extraditing political criminals. The so-called Mitterand doctrine categorically excluded former militants of the extreme leftist group Brigate Rosse (Red Brigades) from extradition. This protection, at least in theory, came with the provision that the fugitives had seized their violent activities and were not responsible for any deaths. However, unlike its name suggests, the practice was never an actual doctrine as it was not based on legislation or any public document. This meant that the offer of asylum could at any time have been cancelled. It has been estimated that around 300 members found refuge on the French side of the border. ${ }^{65}$

In comparison to the French reluctance to extradite members of the ETA or the Brigate Rosse, France was willing to collaborate with West Germany in apprehending fugitives accused of terrorist acts. Carbonneau has linked the extraditions of West German nationals to French foreign policy interests. ${ }^{66}$

One example of such cases was the case of Croissant. It was a highly political case, where France granted the extradition of the fugitive. Klaus Croissant

58 Carbonneau, 1983, 231.

59 Oehmichen, 2009, 297.

60 Carbonneau, 1983, 231.

61 Gilbert, 1998, 304.

62 Gilbert, 1991, 149.

63 Discussed in detail in Section 4.1.5.

64 Oehmichen, 2009, 297.

65 See in more detail on the politics behind the doctrine Lanzoni, 2017. See also e.g. Le Parisien, 14 January 2019, "Battisti arrêté: quel avenir pour les militants italiens qui vivent en France?"

66 Carbonneau, 1983, 221-222. 
had been the attorney of the Baader-Meinhof gang. He fled West Germany and landed in France. West Germany requested his extradition based on his complicity in a terrorist group. More accurately, Croissant was accused of having done propaganda work for the terrorists. The French court gave a 'partially favourable' opinion to his extradition, stating that the gravity of the offence would overrule its political elements. The request and, subsequently, the court decision faced public outcry. Many legal scholars and journalists deemed the request to have been against democratic values such as the freedom of political speech. Additionally, it represented an infringement of the privilege between attorney and client. The extradition of Croissant clashed with the long dedication of France in the promotion of human rights and in its acting as a safe haven for political dissidents. ${ }^{67}$

This application of the Swiss predominance test used in the Croissant case soon formed the basis of many subsequent decisions by the Paris Cour d'Appel (the Court of Appeal of Paris), including the Piperno and Pace case. In this case, Italy requested the extradition of Piperno, who was suspected of participating in the kidnapping and murder of Prime Minister Aldo Moro in 1978. The court ruled that because the crime was extremely grave, the offence could not be considered political. As such, this decision partly applied the Swiss predominance test. ${ }^{68}$ Van den Wijngaert has linked this approach also to the Belgian court practice, where the seriousness of the crimes is evaluated against how closely associated the crimes were with attempting to change the political institutions. The more serious the acts, the closer the connection needed to be. ${ }^{69}$

In the case of Winter of 1978, an interesting reference was made to the exclusion of anarchist crimes from the scope of the protection of the POE. Similar to the Croissant case, the Winter case was also a matter of an extradition request by West Germany from France. Winter was accused of assisting in creating a terrorist group amongst the Nuremberg accused. The aim of the group was to eliminate the "established order of the FRG [Federal Republic of Germany]." The court ruled that acts that aimed at complete social destruction had, since the anarchist acts at the turn of the century, been excluded from the protection of the POE. According to the court, "The social crime, born at the end of the nineteenth century, is distinguished, in criminal law, from the political offence and is considered both by the decisional law and by doctrinal writers, as a common law crime." This doctrine was also applied to a second case of Ingrid Barabass and Sieglinde Hofmann. ${ }^{70}$ However, as discussed, the division between common and social crimes was not as straightforward as the court suggested.

In most cases that concerned the extradition of West German nationals accused of terrorism, the Court of Appeal of Paris ended up granting the request. Court

67 Croissant, Court of Appeal of Paris, 16 November 1977, 2nd decision, 93 J.Trib. (1978). See also Van den Wijngaert, 1980, 123-124; Carbonneau, 1983, 218; Murphy, 1985, 54.

68 See e.g. Murphy, 1985, 54; Gilbert, 1998, 233.

69 Van den Wijngaert, 1980, 125.

70 Cited in Carbonneau, 1983, 221. 
decisions narrowed the concept of political crime by excluding particularly serious crimes and anarchist crimes aimed against the social structures, as opposed to crimes aimed at harming the political order of the state.

However, the courts did not systematically use the narrowed criteria for the application of the POE. In the case of MacCann, the fugitive was accused of, as a member of the Irish Republican Army (IRA), planting two bombs in areas open to the public in the English sector of West Germany. This time, the Court of Appeal of Paris ruled that the acts were indeed of a political character and thus not extraditable, as the explosions had only caused property damage and not resulted in fatalities. According to Carbonneau, this ruling was "totally inconsistent" with the other cases that concerned extraditions to West Germany in the late 1970s. The act was particularly serious and could have been classified as wanton, which would have made it an anarchistic crime instead of a political offence. According to Carbonneau, the court's ruling was related to the fear of IRA retribution in France. ${ }^{71}$

These developments distinctly show that the matter of applying the POE cannot be considered without a link to political issues. While clearly there was a will to not allow terrorists to continue their actions, the question of who is a terrorist was not solved in the 1970s or 1980s. Neither was the depoliticisation trend still evident.

\subsubsection{Interpol's incapability towards terrorism}

Similar to the United Nations, which found its hands tied when trying to create binding antiterrorist provisions, the work of the International Criminal Police Organisation (Interpol) was shadowed by incapability. Since its reorganisation in $1946,{ }^{72}$ the focus of the work of Interpol has been combating ordinary law crimes. It was tied by Article 3 of its constitution: "It is strictly forbidden for the Organisation to undertake any intervention or activities of a political, military, religious or racial character." The aim of this article was to ensure the independence and neutrality of Interpol, "to reflect international extradition law" and to protect individuals from persecution. In determining which crimes fell into the category of ordinary law crimes and which did not, Interpol adopted a case-bycase approach to determining whether the political, military, religious or racial elements dominated. ${ }^{73}$

It seems that Interpol's constitution was modelled on the political offence exception and that the organisation has adopted, or at least intended to adopt, a similar approach to the one applied in the Swiss predominance test when determining the political nature of the crimes. Its 1951 resolution contained the following reference to the predominance test: "[Interpol] recommends to

71 Carbonneau, 1983, 223-224.

72 See e.g. Fooner, 1989, on the history of Interpol.

73 Interpol: Neutrality, Article 3, Interpol Constitution I/CONS/GA/1956. 


\section{Taking the political out of the political}

its members and to the Heads of the National Central Bureaus to see that no request for information, notice of persons wanted and, above all, no request for provisional arrest for offences of a predominantly political, racial or religious character, is ever sent to the International Bureau or to the National Central Bureaus, even if - in the requesting country - the facts amount to an offence against the ordinary law." The evaluation of the nature of the crime was left to the Chief of the International Bureau "in agreement with" the SecretaryGeneral, who were authorised to suspend any request that related to an offence of such nature. ${ }^{74}$

According to Green, this limitation was created due to the unclarity of the nature of political offences and the scope of the POE. ${ }^{75}$ In 1962, Green criticised Interpol for taking a role in policymaking, rather than assisting the police organisations of its member states. According to him, the political nature of the crime should have been decided by either a governmental or a judicial organ, not an administrative police authority. ${ }^{76}$

Regardless of the commitment to the predominance test, Interpol was criticised for not assisting in capturing war criminals and for a too wide interpretation of article $3 .{ }^{77}$ For instance, the Council of Europe argued that too many predominantly common crimes had been protected by the article. ${ }^{78}$

As a consequence of the Munich Olympics massacre in 1972, Interpol took, like the UN, a condemning stance against terrorism. Three weeks after the events at Munich, it formulated the resolution 'Hostages and Blackmail. ${ }^{\text {'79 }}$ The resolution did not specifically make reference to what had happened in Munich, but it was obvious that it was motivated by the events. The resolution condemned the holding of hostages, constituting a menace to the lives and security of persons involved. However, as the organisation was still mindful of the limitations in its constitution, and the restraints of Articles 2 and 3 were underlined. ${ }^{80}$

74 Interpol resolution AGN/20/RES/11, Requests for international enquiries, Lisbon, 1951. Italics orig.

75 Green, 1962, 330.

76 Green, 1962, 354.

77 Green, 1962, 329.

78 Council of Europe Committee of Ministers, Recommendation of the Committee of Ministers to Member States Concerning International Co-operation in the Prosecution and Punishment of Acts of Terrorism. No. R (82), Adopted by the Committee of Ministers at the 342 nd meeting of the Ministers' Deputies, 15 January 1982. The changes in the relationship of Interpol and political crimes are discussed in Chapters 4 and 5.

79 AGN/41/RES/7 Hostages and blackmail, Frankfurt, 1972.

80 Article 2: The aims of the International Criminal Police Organisation-INTERPOL are: (a) To ensure and promote the widest possible mutual assistance between all criminal police authorities within the limits of the laws existing in the different countries and in the spirit of the "Universal Declaration of Human Rights";(b) To establish and develop all institutions likely to contribute effectively to the prevention and suppression of ordinary law crimes. Article 3: It is strictly forbidden for the Organisation to undertake any intervention or activities of a political, military, religious or racial character. 
According to Fenton Bresler, the reason for a wary stance towards terrorism was the fear that any actions against such a politically loaded phenomenon taken by Interpol could have led to its disintegration, as countries such as Syria and Libya might have abandoned it as a result. ${ }^{81}$

The cautious conservatism together with the outdated technology Interpol was using, led to frustration among European police officials. Some wanted the organisation to modernise itself, while some adduced the possibility of the European police collaboration under an organisation named Europol. ${ }^{82} \mathrm{~A}$ more effective approach to combating terrorism in Europe was needed, and as the first step in 1976, a collaboration group in the fight against violent crimes, TREVI, was founded to tackle this problem. ${ }^{83}$

The dissatisfaction towards Interpol might have been one cause for the switch of attitude in the organisation during the following decade. Coming to the late 1970s, international terrorism had proved to be one of the most imminent or most publicised threats for Western states. The late 1970s witnessed notable changes in how terrorism was viewed and dealt with within European states, as well as globally.

\subsubsection{Terrorism alerts Europe in the 1970s}

The perceived growth in the terrorist threat in the 1970s engaged the Council of Europe as well as the European Economic Community (EEC) in the fight against terrorism. This had become a political necessity, as a growing number of terrorist events that involved European states took place during the decade. ${ }^{84}$

Both the EEC as well as the Council of Europe took a wide variety of forms of action against terrorism. This section does not attempt to cover all the relevant policies but points to some of the key developments.

The European Convention on Extradition of 1957, which aimed at facilitating extradition between signatory states, forms the basis of European extradition agreements. It is the extradition regime with the widest application still today, as it has been ratified by 47 Council of Europe members and 3 non-members: Israel (1967), South Africa (2003) and South Korea (2011). The convention contains the political offence exception and the discrimination clause, with the limitations of the Belgian clause. ${ }^{85}$ Similarly, the 1959 European Convention on

81 Interpol documentary, 2007.

82 Andreas and Nadelmann, 2006, 100. Europol was officially formed in 1998. Europol Convention, 95/C 316/01, 26 July 1995.

83 TREVI was either named after the famous fountain in Rome or as a French acronym for the subject of its mandate - terrorism, radicalism, extremism and international violence (Terrorisme, Radicalisme, Extrémisme et Violence Politique). Andreas and Nadelmann, 2006, 101. TREVI is discussed in more detail in the following chapter.

84 See e.g. Lodge, 1981, 172.

85 Article 3, para 1, European Convention on Extradition, European Treaty Series No. 24, 13 December 1957. 


\section{Taking the political out of the political}

Mutual Assistance in Criminal Matters provides that assistance can be refused if the offence in question is a political offence or connected therewith. ${ }^{86}$ The fact that the UK took many years to ratify these treaties ${ }^{87}$ has been interpreted as a demonstration of the difficulty in bringing together common and civil law countries. $^{88}$

Similar to the UN and Interpol, the Council of Europe was forced to quickly react to the events in Munich in September 1972. This resulted in the creation of the Recommendation on International Terrorism, which aimed at improving collaboration against terrorist activities. The recommendation did not discuss the political nature of terrorism. ${ }^{89}$ As the name suggests, the council's recommendations are not binding on member states. ${ }^{90}$ The following year, a new Recommendation on International Terrorism was created. This recommendation "Condemn[ed] international terrorist acts which, regardless of their cause, should be punished as serious criminal offences." "The recommendation called for the establishment of a common definition of 'political offence' "in order to be able to refute any 'political' justification whenever an act of terrorism endangers the life of innocent persons." $" 92$

It is interesting to note that the recommendation called for a common definition of 'political offence' instead of a common definition of terrorism. It seems that at this stage, the Council of Europe considered it easier to create a definition of political offences, which would exclude a variety of violent acts, rather than open Pandora's box and trying to create a definition of terrorism instead.

Since the 1972 recommendation, terrorism has become a common topic discussed amongst members of the Council of Europe. In 1973, Recommendation 703 on International Terrorism suggested that the Committee of Ministers of the Council of Europe should create "a joint European front to combat terrorism" and invite the governments of member states inter alia, again, "to establish a common definition for the notion of 'political offence', in order to be able to refute any 'political' justification whenever an act of terrorism

86 Article 2, European Convention on Mutual Assistance in Criminal Matters, Strasbourg, 20 April 1959.

87 It signed and ratified both treaties only at the beginning of the 1990s. Signatures and ratifications, European Convention on Mutual Assistance in Criminal Matters, Strasbourg, 20 April 1959. https://www.coe.int/en/web/conventions/full-list/-/conventions/treaty/030/ signatures Signatures and ratifications, European Convention on Extradition, 13 December 1957. https://www.coe.int/en/web/conventions/full-list/-/conventions/treaty/024/ signatures?p_auth=S9oLjL3Y. Retrieved 29 November 2017.

88 Freestone, 1981, 206.

89 Recommendation 684 on International Terrorism, Parliamentary Assembly of the Council of Europe, 23 October 1972.

90 Lodge, 1981, 169.

91 Para 1, Parliamentary Assembly of the Council of Europe Recommendation 703 on International Terrorism, 16 May 1973. Italics added.

92 Para 6(i)(c), Parliamentary Assembly of the Council of Europe Recommendation 703 on International Terrorism, 16 May 1973. 
endangers the life of innocent persons." 93 The common definition was never created.

In 1974, the Committee of Ministers of the Council of Europe adopted Resolution (74) 3 on International Terrorism. While it urged member states to either extradite or prosecute crimes mentioned in the UN Hague and Montreal Conventions of the previous years, it, again, made note of the political nature of terrorism. It urged states to "take into consideration the particularly serious nature of these acts, inter alia: when they create a collective danger to human life, liberty or safety; when they affect innocent persons foreign to the motives behind them." $"$ It thus encouraged member states to extradite those accused of these crimes but did not fail to remind of the motives behind the violence.

In 1975, as a reaction to Interpol's incapability in the fight against terrorism, the so-called TREVI group was established to improve European collaboration against international terrorism, radical extremism and international violence. The TREVI collaboration was an intergovernmental forum where Ministers of Interior and Justice of the European Communities met regularly. TREVI started out as a measure to counter the terrorist threat, but soon its mandate widened to other forms of cross-border crime. It ended up creating a system of liaison officers and a common information sharing mechanism. ${ }^{95}$ The TREVI group's activities slowly evolved more and more towards structures that would later form the basis of the European Police Office (Europol). ${ }^{96}$

In 1976, after the liberation of the Entebbe hostages, who had been on a hijacked aeroplane originally headed to Tel Aviv but forced to fly to Uganda, ${ }^{97}$ all the party groups of the European Parliament wanted to dedicate themselves to the fight against terrorism and adopted a resolution to combat international terrorism. ${ }^{98}$ The Political Affairs Committee of the European Parliament wanted terrorism to be considered as a crime "similar to, if not worse than, the old international crime of piracy," and one that, like piracy, should be dealt with differently from other crimes. ${ }^{99}$

The same year, a meeting brought together the Ministers of the Interior and of Justice of the member states of the European Council with the primary goal to "deal with issues arising out of international terrorism and the desire to apprehend and prosecute fugitive terrorists." This meeting initiated the process that

93 Recommendation 703 (1973) on International Terrorism, para 6(i)c. See also Lodge, 1981, 167; and Müller-Rappard, 1988, 395.

94 Resolution (74) 3 on International Terrorism (Adopted by the Committee of Ministers on 24 January 1974 at its 53 rd Session). Italics added.

95 Hebenton and Thomas, 1995, 70-71.

96 Hebenton and Thomas, 1995, 84.

97 See in more detail e.g. The Guardian, 25 June 2016, "We thought this would be the end of us': the raid on Entebbe, 40 years on."

98 Lodge, 1981, 173. See in more details the political debate surrounding the development of the EEC's antiterrorism policy in the 1970s. Lodge, 1981.

99 Cited in Lodge, 1981, 177. 
led to the creation of the European Convention on the Suppression of Terrorism (ECST) in 1977. ${ }^{100}$ The ECST was the first international antiterrorist convention that was ratified by several European states. ${ }^{101}$ The ECST was also the first international convention to depoliticise terrorism as a phenomenon. The depoliticisation was enabled by the Council of Europe Member States' mutual confidence in each other's legal orders.

The aim of the ECST was to fill the gap created by the POE, which had, on certain occasions, resulted in the protection of terrorists. However, when it was planned, it proved too difficult to accept that all political offences would amount to obligatory extradition. Instead, it was seen that each case could be examined separately. ${ }^{102}$ One of the fears related to the establishment of an antiterrorism policy in Europe was that the same measures could be used against civil liberties. ${ }^{103}$ For this reason, the decision-making remained cautious.

The ECST excluded a variety of violent offences from the scope of political offences. Article 1 listed the offences that would not be considered as political offences or connected offences, or acts inspired by political motives for the purposes of extradition. ${ }^{104}$ The ECST made reference to the Hague and Montreal Conventions and excluded crimes committed against internationally protected persons. In addition, the ECST depoliticised kidnappings, hostage takings and other serious unlawful detentions, as well as offences involving the use of a bomb, grenade, rocket, automatic firearm, or a letter or parcel bomb, if lives were endangered. It also excluded any attempts to commit such offences or participation as an accomplice from the POE.

The ECST did not depoliticise the acts themselves, but did so only for the purposes of extradition between contracting states: "For the purposes of extradition between Contracting States, none of the following offences shall be regarded as a political offence or as an offence connected with a political offence or as an offence inspired by political motives. ${ }^{105}$ The aim was to eliminate the possibility of invoking the POE when facing an extradition request. However, as the ESCT was not an extradition treaty as such, this elimination did not mean that

100 Hebenton and Thomas, 1995, 4.

101 European Convention on the Suppression of Terrorism, ETS No. 90, 27 January 1977. See in detail also Müller-Rappard, 1988.

102 Explanatory Report to the European Convention on the Suppression of Terrorism, ETS No. 90, 27 January 1977.

103 Lodge, 1981, 175.

104 Additional Protocol to the European Convention on Extradition, ETS No. 86, 15 October 1975. Prior to this, a similar limitation had been set - "political offences shall not be considered to include the following" - by the UN Genocide Convention as well as Article 1 of the Additional Protocol to the European Convention on Extradition for certain crimes against humanity and for violations of the laws and customs of war, as well as in Article VII of the United Nations Convention on the Prevention and Punishment of the Crime of Genocide.

105 Article 1, European Convention on the Suppression of Terrorism, ETS No. 90, 27 January 1977. Italics added. 
other exceptions could not be invoked. In addition, Article 1 was subject to reservations. ${ }^{106}$

Altogether eight states reserved "the right to refuse extradition in respect of any offence mentioned in Article I which it considers a political offence." Italy went so far to state that it would not extradite for a "political offence, an offence connected with a political motive or an offence inspired by political motives."107 Ireland took the controversial position that it was against customary international law to extradite political offenders. ${ }^{108}$ According to Geoffrey Gilbert, this "effectively sabotage[d] the fundamental purpose of the ECST."109

Article 2 of the ECST made it possible for a contracting state not to regard as political or as connected offences a number of serious offences against persons or property. However, this was already possible under any traditional extradition rule. States had always had the right to consider acts of terrorism as common crimes. Thus, the ECST merely confirmed this right. ${ }^{110}$

Article 5 of the ESCT contained the so-called discrimination clause, which further allowed a state to deny extradition in case it considered the request to be ideologically or politically motivated. Gilbert has pointed out that such a provision should not have been considered necessary between states which had dedicated themselves to the provisions of the European Convention of Human Rights (ECHR). ${ }^{111}$ Klabbers has argued that this article is, in fact, contradictory to the depoliticisation of terrorism done in Article 1 as it brings out attention to the political nature of terrorism. Additionally, he has argued that the request for the extradition of a terrorist is, by nature, of political nature, as terrorists themselves are political actors and can be persecuted for their political opinions. ${ }^{112}$ This argument is of interest, especially because some have claimed that the political offence exception could be replaced by the discrimination clause. ${ }^{113}$ The two, however, provide different protection: while the POE acknowledges the political motivation of the crime, the discrimination clause does not make a difference between political and so-called common crimes but instead looks at the motivation of the requesting government. As such, it does not repoliticise the committed crime, but instead, looks at why the request has been made.

Article 7 created the obligation to either extradite or prosecute. This did not mean that the convention contained the principle aut dedere aut judicare. The ECST gave priority to extradition, meaning that prosecution was a subsidiary

106 Article 13, European Convention on the Suppression of Terrorism, ETS No. 90, 27 January 1977.

107 Gilbert, 1991, 142. Italics orig.

108 Murphy, 1985, 15.

109 Gilbert, 1998, 287. A similar note was made by Murphy, 1985, 14.

110 Van den Wijngaert, 1980, 48; Müller-Rappard, 1988, 399; Explanatory Report to the European Convention on the Suppression of Terrorism, ETS No. 90, 27 January 1977.

111 Gilbert, 1991, 141.

112 Klabbers, 2004, 306.

113 See in more detail Chapter 5, Section 5.2.5. 
means to be used in case an extradition request was turned down. ${ }^{114}$ Additionally, there was no requirement for the case to be tried (judicare), but only that the case would be submitted for prosecution. ${ }^{115}$

Finally, Article 8 of the ECST removed the right for a state to refuse mutual assistance for political offences. This obligation was subject to reservations.

The role of the ECST was to complement and, where necessary, modify preexisting extradition treaties between member states. ${ }^{116}$ The legal basis of extradition still remained the relevant extradition treaty or other law. This meant that states could still refuse extradition for crimes in the convention if other conditions of extradition were not filled. ${ }^{117}$ The only legally binding element in the convention is that the countries that ratified it were committed to collaborating in the matter of serious offences that were covered by international conventions. ${ }^{118}$ There are plans to further amend the ECST to exclude a wider list of terroristic crimes and to strengthen the discrimination clause. ${ }^{119}$ However, these plans have not gone forward.

Alex P. Schmid has criticised the ECST for inconsistency. Acts mentioned in the ECST can be terroristic under some circumstances and not under others. ${ }^{120}$ "[It] can place a hijacker who is attempting to escape from a terror regime in the same category as a 'real' (i.e. triadic) terrorist." Further, according to, for instance, Müller-Rappard, the ECST failed at eliminating the possibility of considering terrorist crimes political offences or offences connected with political offences. ${ }^{121}$ However, its political importance has been underlined. ${ }^{122}$

According to Geoffrey Gilbert: "The ECST is, thus, clumsy and inelegant, even incoherent, from an academic legal viewpoint, but justifiable and understandable if seen within the context of a socio-legal viewpoint." ${ }^{123}$ Also according to Juliet Lodge, the ECST gave a clear signal: "the plea that a terrorist act is politically inspired, justifiable and defensible is no longer to be regarded as justifying non-prosecution of a terrorist." 24

It is clear that the ECST represented a major change in the way in which the link between the POE and terrorism was viewed. Because of the initial steps of European unification had taken place, it became easier for European states to

114 Explanatory Report to the European Convention on the Suppression of Terrorism, ETS No. 90, 27 January 1977.

115 Explanatory Report to the European Convention on the Suppression of Terrorism, ETS No. 90, 27 January 1977; Müller-Rappard, 1988, 403-404.

116 Müller-Rappard, 1988, 399; Gilbert, 1991, 141.

117 Explanatory Report to the European Convention on the Suppression of Terrorism, ETS No. 90, 27 January 1977.

118 Müller-Rappard, 1988, 402.

119 Harrington, 2015, 161.

120 Schmid, 1984, 101.

121 Müller-Rappard, 1988, 395.

122 Freestone, 1981, 214; Schmid, 1984, 103.

123 Gilbert, 1998, 289.

124 Lodge, 1981, 171. 
join forces against evil and deny the protection for political offenders, even if not completely.

As a follow-up to the creation of the ECST, President Valéry Giscard d'Estaing began promoting the l'Espace Judiciare Européen, the European Judicial Area, which aimed at tightening the net around fugitives of law, especially terrorists, by creating a European extradition system. This idea formed a part of a larger plan to strengthen the independence of the European Economic Community and to secure French leadership in it. ${ }^{125}$

The ratifications of the ECST were slow, which has been interpreted as a sign of distrust between the signatory states. ${ }^{126}$ After the killing of Italian Prime Minister Aldo Moro in 1978, the European Parliament tried to push EEC members to ratify the ECST. The same year, the EEC Ministers of Justice agreed to observe a common stance on extraditing or prosecuting EEC nationals accused of terrorist acts, even if most member states did not have specific antiterrorist legislation. However, the ministers wanted to guarantee more freedom in comparison to the Council of Europe's approach in the application of the POE. They decided that extradition could be denied based on the political nature of the crime in question, but in such a case accused terrorist acts were to be submitted to the national authorities for prosecution. ${ }^{127}$ Lodge has noted that during this time, the European Parliament kept stressing the need to determine and eliminate the causes of terrorism. ${ }^{128}$

The Dublin Convention, or the Agreement Concerning the Application of the European Convention on the Suppression of Terrorism among the Member States of the European Communities, of 1979 also aimed at improving the application of the ECST. The goal was to make Articles 1, 8 and 13 of the ECST applicable between all member states of the European Communities, regardless of whether they were a party to the ECST or had ratified it. However, the Dublin Convention also ended up not being ratified in spite of being signed by all members of the European Communities. ${ }^{129}$

Even if the ECST was not as efficient as hoped for, it had implications to other extradition treaties, even outside Europe. For instance, the UK-India extradition treaty of 1993 was modelled on it. ${ }^{130}$ This treaty excluded from the scope of the

125 Carbonneau, 1983, 217.

126 Gilbert, 1991, 142.

127 Lodge, 1981, 179-182.

128 Lodge, 1981, 190-191. Nonetheless, Lodge argued in 1981 that the focus of governments was more on creating antiterrorist measures rather than in investigating the causes of terrorism. Lodge, 1981, 226-227.

129 Agreement Concerning the Application of the European Convention on the Suppression of Terrorism among the Member States of the European Communities (the Dublin Convention), Assembly Document 4460, 17 December 1979. See also Müller-Rappard, 1988, 408-409; and Murphy, 1985, 15-16.

130 Extradition Treaty between the Government of the Republic of India and the Government of the United Kingdom of Great Britain and Northern Ireland, 30 December 1993. 
POE for instance murder, or "the possession of a firearm or ammunition by a person who intends either himself or through another person to endanger life." In addition to excluding a long list of violent crimes as well as the UN conventions which related to terrorism, ${ }^{131}$ the UK-India treaty specifically mentioned "any other offence[s] relating to terrorism under the law of the Requested Party" which were "not to be regarded as [an] offence[s] of a political character." 132

The Council of Europe, which drafted the ECST, is an organisation dedicated to specific values: democracy, human rights and the rule of law. For this reason, its statements are more openly ideological than those of any of the other organisations studied. Even if it had dedicated itself to countering terrorism within Europe, it still had a controversial take on the matter.

In 1979, it created Recommendation 852 on Terrorism in Europe, which is especially interesting. First, it claims that the Assembly of the Council was "Convinced that there is no justification for politically motivated violence in a democratic society where legal provision is made for change, improvement and development by means of political persuasion, and that, consequently, terrorism is an attack against the constitution and the democratic stability of the state." ${ }^{133}$ In the following paragraph, however, it still acknowledged the political roots of the terrorist problem and urged its member states to enhance their democratic structures for the purpose of removing these "sociological conditions" behind these acts. ${ }^{134}$

In its 1981 Recommendation 916 on the Conference on "Defence of Democracy Against Terrorism in Europe - Tasks and Problems," the Assembly of the Council of Europe made note "that it was generally agreed at the conference that in Council of Europe member countries the aim of terrorist movements, whatever their names or origins, is to overthrow and destroy democracy and parliamentary institutions, as well as stifle the free political, economic and social development that only a democratic system permits." ${ }^{\prime 35}$ The conference also underlined the importance of studying the role of culture, education and mass media on the phenomenon as well as, following the lines of the UN: "a study and documentation centre of the causes, prevention and suppression of terrorism." 136

131 As mentioned, these have only later been named the antiterrorism conventions.

132 Article $5(2)(\mathrm{e})(\mathrm{j})(\mathrm{o})$, Extradition Treaty between the Government of the Republic of India and the Government of the United Kingdom of Great Britain and Northern Ireland, 30 December 1993. See also e.g. Article 5, Extradition Treaty between the Government of Canada and the Government of India, 6 February 1987, containing similar provisions.

133 Para 4, Parliamentary Assembly of the Council of Europe Recommendation 852 on Terrorism in Europe, 31 January 1979.

134 Para 5, Parliamentary Assembly of the Council of Europe Recommendation 852 on Terrorism in Europe, 31 January 1979.

135 Para 5, Parliamentary Assembly Council of Europe Recommendation 916 on the Conference on "Defence of Democracy Against Terrorism in Europe - Tasks and Problems," 26 March 1981.

136 Para 13(h), Parliamentary Assembly Council of Europe Recommendation 916 on the Conference on "Defence of Democracy Against Terrorism in Europe - Tasks and Problems," 26 March 1981. 
These recommendations demonstrate that the tackling of terrorism was not in any way simple in Europe during the 1970s and in the early 1980s. The political roots of terrorism made it a difficult topic to agree upon, even within member states committed to democratic values and rejecting the use of violence as a tool for political change.

Since the early years of the 1980s, there was a clear shift in European policies. Little by little, less attention was paid to the grievances motivating terrorist acts. Pushing aside the politics behind terrorist acts in the early years of the 1980s is a noteworthy change in the way in which terrorism was understood. In 1982, Recommendation 82 no longer mentioned the political nature, causes or motivations of terrorism. ${ }^{137}$ In 1984, the Assembly of the Council argued that what made terrorism so reprehensible was its totalitarian character and the threat it poses to democracy and its violation of human rights. For this reason, the measures used against it should never violate human rights or be antidemocratic. According to the council in Recommendation 982, "the fight against terrorism cannot justify the establishment of regimes - or the adoption of measures - of a fascist nature, which are as hateful as terrorism itself and for the same reason." 138

\subsubsection{The Iranian hostage crisis provokes a global reaction in 1979}

Based on the findings of the current research, the year 1979 is an important turning point with regard to global views on terrorism. The hostage crisis in Iran opened a new era of state-sponsored terrorism as a deliberated instrument of foreign policy. Typically, the major terrorist organisations from the 1960s until the 1990s were ideological, ethno-nationals and separatist organisations. ${ }^{139}$ The hostage crisis, however, brought terrorism onto the field of international power politics. For this reason, it made terrorism a more pressing problem than it had even been globally, and particularly to the US.

During the widely publicised siege, 52 Americans were held hostage in the embassy in Tehran by militant Iranian 'students,' who were perceived as acting on behalf of the newly established Iranian regime. This was the starting point of an anti-American terrorist campaign by Iran. ${ }^{140}$

The events in Iran provoked a new type of reaction from the UN. As an immediate counteraction to the hostage crisis, the UN General Assembly drafted

137 Council of Europe Committee of Ministers, Recommendation of the Committee of Ministers to Member States Concerning International Co-operation in the Prosecution and Punishment of Acts of Terrorism. No. R (82), Adopted by the Committee of Ministers at the 342 nd meeting of the Ministers' Deputies, 15 January 1982.

138 Para 3, Council of Europe Parliamentary Assembly Recommendation 982 on the Defence of Democracy Against Terrorism in Europe, 9 May 1984.

139 Hoffman, 1998, 200.

140 See e.g. Trager (ed.), 1986, 4; Hoffman, 1998, 186. See contemporary news stories documenting the hostage crisis Trager (ed.), 1986, 4-21. 


\section{Taking the political out of the political}

the International Convention Against the Taking of Hostages, or Hostages Convention, in 1979. The convention condemns "all acts of taking hostages as international terrorism." ${ }^{141}$ This was the first UN instrument that openly labelled the threat as terrorism. Several previous instruments are classified as antiterrorist instruments, but they did not mention the term.

The aim of the Hostages Convention was to close the gap between humanitarian law and law that related to individual terrorist acts so that all cases of hostage-taking would either be covered by the convention or by the law of armed conflict. $^{142}$

The Hostages Convention, like many other sectoral antiterrorist UN conventions, contained the aut dedere aut judicare principle as well as the discrimination clause. The Hostages Convention, however, does not depoliticise hostage-taking. In fact, Article 15 of the convention specifically mentions that treaties on asylum would not be affected. As noted by Ben Saul, because these treaties were not specified, it is unclear if they include the Refugee Convention of 1951, which excludes from its scope persons who have committed serious non-political crimes. ${ }^{143}$ According to Saul, some acts of hostage-taking could, for this reason, be considered non-political under both international refugee law and certain national extradition laws. ${ }^{144}$ For instance, Australia went beyond what the convention necessitated and depoliticised the crimes covered by the convention in its national extradition law. ${ }^{145}$

In addition to the UN, the year 1979 was also an important watershed for Interpol. The resolution of the 1979 Acts of Violence Committed by Organised Groups, created as a reaction to the siege, argued that there were criminal groups claiming to be ideologically motivated. ${ }^{146}$

This is a minor choice of words but a major policy change. Earlier, a claim of ideological motivation had been taken at face value. The Acts of Violence Committed by Organised Groups marked the first time when the motivation and the act were separated from each other. Thus, the Iranian embassy crisis became the first milestone for a new, stricter global view on terrorism.

The developments of the 1980s continued to challenge previous views of treating terrorism as a political threat and of understanding its causes.

141 The International Convention Against the Taking of Hostages [Hostage taking Convention], UN Doc. A/Res/34/146; 1316 UNTS 205; 18 ILM 1456, 17 December 1979.

142 Murphy, 1985, 11.

143 Article 1 F(b), United Nations Convention Relating to the Status of Refugees, 28 July 1951.

144 See for a detailed analysis of the Hostages Convention e.g. Saul, 2014.

145 Australia, Extradition Regulations (1988), Reg. 2B(1)(d) cited in Saul, 2014.

146 Interpol resolution AGN/48/RES/8, Acts of violence committed by organised groups, Nairobi, 1979. Italics added. 


\subsection{Reagan, Thatcher and the narrowing of the exception in the 1980s}

\subsubsection{Legislative war against terrorists}

As the United States was itself built on rebellion, it was for a long time sympathetic towards revolutionaries. It had since its independence in 1776 been known as a safe haven for political dissidents and criminals. ${ }^{147}$ This view gradually changed in the 1970s and 1980s, as the US started to alter its interpretation of the POE.

In the 20th century, the US became an 'old nation' and established its position as a great power. It had a growing amount of political and business interests around the world, which led to its defending stability over ideology. Foreign conflicts that had previously been seen as distant distractions now became part of US interests. With the end of its isolationist ideology, its interests were more and more attached to the rest of the world. The bureaucratisation of the US by the end of the 20th century led to its sympathising with foreign law enforcement agencies instead of rebel groups. The core interest of the US was now to recover fugitives, not to protect foreign rebels. Additionally, arms trade tied the US with other established regimes rather than with revolutionist groups. Rebels against nations that were connected to US interests were considered terrorists. Rebels against Communist regimes were still treated as freedom fighters. ${ }^{148}$

A number of highly publicised terrorist events confirmed the Reagan administration's dedication to the fight against terrorism. The commitment to this cause was not only visible in US foreign and domestic policies, but it was also reflected by the changes in US courts' interpretation of the POE. Additionally, some of the key US extradition treaties were re-formulated in order to facilitate the return of fugitive terrorists. ${ }^{149}$ According to Christopher H. Pyle: "The effort to strip alleged terrorists of political offender status was as much a propaganda war as it was a legal one."150 One of the main catalysts of this change was the political companionship between the UK and the US.

\subsubsection{Eain v. Wilkes of 1980 as a departure from the incidence test}

During the 1980s, several US court decisions denied extradition for criminals who had committed violent acts. This provoked a call for reform of the law and the application of the exception both from politicians as well as scholars. ${ }^{151}$ This publicity and criticism pushed governments to use alternative methods to return fugitives so that they could avoid dealing with the exemption. Terrorists did not

147 Pyle, 2001, 77.

148 Pyle, 2001, 142-143.

149 Groarke, 1988, 1515; Petersen, 1992, 773.

150 Pyle, 2001, 168.

151 See e.g. Lubet, 1982; and Sofaer, 1986. 


\section{Taking the political out of the political}

find safe haven in the US in masses. On the contrary, the majority of those who had committed terrorist crimes were in fact extradited, but the focus remained on those who were not. ${ }^{152}$

US courts gradually started to apply the POE in a more restrictive way, even if the new interpretation was not consistent and no overnight transformation took place. A landmark decision was that of Eain $v$. Wilkes, where the Seventh Circuit court rejected the incidence test traditionally applied in cases concerning allegedly political crimes. Upon appeal of the case, the Seventh Circuit Court of Appeals employed a new stricter interpretation of the POE and concluded that a direct political effect needed to follow an act for it to fall into the political offence category. ${ }^{153}$

Eain was accused of bombing a marketplace in Israel, resulting in the deaths of two young boys. Given that Eain was a member of the Al Fatah faction of the Palestine Liberation Organisation, ${ }^{154}$ involved in an ongoing conflict between Israel and the Palestinian Arabs, and the motivation of the bombing was political, the traditional incidence test would have most likely resulted in the refusal of his extradition. ${ }^{155}$

The court tried to overcome the problem that had previously presented itself in the Artukovic case ${ }^{156}$ by underlining the difference between acts targeted against the "political order of the state," which were considered as truly political, as opposed to those that were targeted against the "social structure." The latter ones were deemed as "anarchist-like," and thus excluded from the scope of the political offence exception. ${ }^{157}$ The decision reflected the British case In re Mennier of $1894^{158}$ in which the court concluded that anarchist acts could not be protected by the POE. ${ }^{159}$ Nonetheless, after Eain's extradition as a common criminal, Israel classified him as a prisoner of war. ${ }^{160}$

The Eain reasoning has been labelled the Seventh Circuit Court of Appeals' 'wanton crimes' exception to the political offence doctrine. ${ }^{161}$ If the crime

152 Gilbert, 1991, 135.

153 Schlaefer, 1981, 641; Gilbert, 1985, 700; Kulman, 1986, 768-769.

154 Eain v. Wilkes, 64l F.2d 504 (7th Cir. 1981).

155 Schlaefer, 1981, 642. However, Noone and Alexander have argued that the application of the incidence test would have not resulted in protection, as the members of the PLO entered the territory of a different state. According to them, the exception was aimed at protecting those attempting to change their own government or to drive out occupying forces. Noone and Alexander, 1997, 98.

156 See Chapter 3, Section 3.2.3.

157 See e.g. Hannay, 1980, 402-406; Schlaefer, 1981, 638-641; Banoff and Pyle, 1984, 185; Kulman, 1986, 769; Sapiro, 1986, 676-677; Lampo, 1988, 243-245; Pyle, 1988, 189; Noone and Alexander, 1997, 84-90; Pyle, 2001, 155- 158; and Lieberman, 2007, 194195 , for details of the decision.

158 See Chapter 3, Section 3.3.2.

159 Lieberman, 2007, 195.

160 Pyle, 2001, 158.

161 Lampo, 1988, 244; Pyle, 2001, 156. 
was 'wanton,' the perpetrator was not entitled to protection from extradition. According to Christopher H. Pyle, the wanton crimes exception was a more efficient way to respond to the same problem the attentat clause, the Meunier exception for anarchist offences and the multilateral antiterrorist conventions since the 1970s had attempted to solve. Writing in 2001, Pyle was hopeful that the Eain decision could have set a "precedent that might, in time, bring the law of extradition for at least some non-international conflicts into line with the law governing international wars." The wanton crimes exception matched the original humanitarian purposes of the POE. However, some of the government attorneys were not satisfied with the reasoning and still hoped to get rid of the POE or transfer it to the executive to decide. ${ }^{162}$

The Eain decision did not prevent the application of the POE to 'wanton crimes,' as only courts within the Seventh Circuit were bound by the Eain precedent. ${ }^{163}$ The decision was in fact not followed by other jurisdictions. Additionally, it never excluded all attacks against civilians from the POE, and did not take a stance on whether attacks on individual military or other government personnel, such as policemen, constituted political acts, meaning acts that "disrupt the political structure of a state" or non-political acts that "disrupt the social structure." In Eain, the decision of the court was based on the lack of direct links between the specific crime, its perpetrator and the goals of a political organisation. ${ }^{164}$ Thus, it was no solve-all solution to the problem of terrorists and the POE.

The reasoning behind the Eain decision was widely criticised. For instance, the court in the famous case of Quinn ${ }^{165}$ was critical of the reasoning behind the Eain decision. It stated: “[T]here is no justification for distinguishing $[\ldots]$ between attacks on military and civilian targets. The 'incidental to' component, like the incidence test as a whole, must be applied in an objective, non-judgmental manner; it is for revolutionaries, not the courts, to determine what tactics may help further their chances of changing the government." 166 Additionally, the judges' own political preferences could easily affect the way in which they interpreted the cases. ${ }^{167}$ Others have blamed the Eain decision for an "emotionalism." The disagreement on the Eain decision proved that there was a division of views regarding the application of the POE, especially with regard to acts of terrorism. ${ }^{168}$ In some years' time, the 'wanton crimes limitation' proved to be inefficient as the criteria for its application remained unclear. ${ }^{169}$ Further, the division between anarchist crimes and other types of political offences was considered unrealistic and

162 Pyle, 2001, 157.

163 Lampo, 1988, 244.

164 Sofaer, 1986, 131.

165 Quinn v. Robinson, 783 F.2d 776, 783 (9th Cir. 1986). The Quinn case will be discussed in detail in this chapter later.

166 Quinn v. Robinson, 783 F.2d 776, 783 (9th Cir. 1986). Cited in Kulman, 1986, 769.

167 Lieberman, 2007, 197.

168 Lampo, 1988, 244-245.

169 Kulman, 1986, 779. 


\section{6}

has been interpreted as a sign of the courts' frustration with terrorist acts passing as political offences in the application of the POE. ${ }^{170}$

It has been argued that the Eain decision reflected a wider understanding in US courts concerning extraditions to the Middle East. Steve Lampo has claimed that in comparison to requests that came from Britain, demands for extradition from Middle Eastern states were accepted more often. ${ }^{171}$ This is a very interesting remark. Both Britain and Israel have typically been seen as US allies but, additionally, British legal culture is widely shared with the US due to the inheritance of the common law tradition. The reason why the US ended up denying extradition for political offenders that escaped Britain had to do with wider internal political concerns relating to the political power of the Irish minority in the country. This topic is discussed in more detail later.

A similar case to that of Eain was that of Abmad v. Wigen of 1989. Israel accused Ahmad of attacking a bus in Tel Aviv with Molotov cocktails and machine guns. ${ }^{172}$ The US court reasoned that the attack was not incidental to any political uprising. Additionally, in its decision, the court made a surprising reference to the Additional Protocol I of 1977 of the Geneva Conventions, a treaty not ratified by the US, Israel, PLO or most other nations of the world. Extradition was finally denied on the basis that Ahmad's acts violated the laws of armed conflict.

Interestingly, Ahmad tried to claim that he would not receive a fair trial if returned to Israel. However, the US-Israel extradition treaty did not contain the discrimination clause. ${ }^{173}$ The rule of non-inquiry prevented US judges from evaluating the Israeli justice system, and the court put the burden of proof on the accused to demonstrate that he would receive unfair treatment upon his return. Regardless of reports concerning human rights violations within the system, the petition was denied. It has been suggested that the decision was based on foreign policy concerns rather than judicial: the court did not want to get meddled into foreign politics. As such, the case demonstrates the dangers of case-by-case decision-making and giving the judiciary a (very limited) role in the evaluation of other countries' judicial systems. ${ }^{174}$

After Eain, American courts still, for the most part, continued to apply a more liberal approach to the incidence test compared to their British counterparts and kept following the reasoning introduced in the Ezeta case in 1894. ${ }^{175}$ Eain was the only case in the first part of the 1980s where the morality of the conduct was examined. ${ }^{176}$ The trend of narrowing the scope of the POE did not otherwise seem to affect the actions of US courts during the first part of the 1980s and violent offenders continued to successfully use the POE as a defence. ${ }^{177}$

170 Banoff and Pyle, 1984, 186.

171 Lampo, 1988, 247.

172 Ahmad v. Wigen, 726 F. Supp. 389 (E.D.N.Y. 1989), aff'd, 910 F.2d 1063 (2d Cir. 1990). See for more details on the case e.g. Pyle, 2001, 164-167.

173 Israel International Extradition Treaty with the United States, 10 December 1962.

174 Petersen, 1992, 793-794. See also Pyle, 2001, 167.

175 See Chapter 2, Section 2.2.5.

176 Banoff and Pyle, 1984, 188.

177 Kulman, 1986, 766. 
Valerie Epps has linked the US courts' doctrine with the increase in international communication and interdependence. The courts followed US foreign policy goals in their application and interpretation of the POE. ${ }^{178}$ Also, Geoffrey Gilbert has connected the outcomes of court decisions more to foreign policy goals than to solid legal reasoning. Court decisions were often affected by bilateral policy concerns. A fugitive trying to escape a Communist country received a different decision than a fugitive on the run from a state with which the US had important trade relations or which policies received support within the country. ${ }^{179}$

\subsubsection{Terrorism starts to affect the US in the 1980s}

The 1980s witnessed an encompassing metamorphosis in US antiterrorism and extradition policies. The threat of terrorism, the growth in drug trafficking and the attempts to retrieve war criminals from the Holocaust, together with a steady rise in the number of extradition requests slowly started to affect US extradition treaties. ${ }^{180}$ Extradition was growlingly used as a weapon in 'wars' against crime. ${ }^{181}$

Still, in the late 1970s and 1980s, terrorism was understood as mostly a political threat. For instance, US Secretary of State William P. Rogers (1969-1973) acknowledged the political goals behind terrorist actions, but underlined that "political passion cannot justify criminal violence against innocent persons." 182 Similarly, President Ronald Reagan (1981-1989) stated in his 1986 radio address:

In our world, there are innumerable groups and organisations with grievances, some justified, some not. Only a tiny fraction has been ruthless enough to try to achieve their ends through vicious and cowardly acts of violence upon unarmed victims. Perversely, it is often the terrorists themselves who prevent peacefully negotiated solutions. So, perhaps the first step in solving some of these fundamental challenges in getting to the root cause of conflict is to declare that terrorism is not an acceptable alternative and will not be tolerated. ${ }^{183}$

Thus, unlike with the current depoliticisation trend, the political goals and motives were still acknowledged.

Before the 1990s, terrorism was mostly seen as an organised movement that was led by the Soviet Union and supported by Middle Eastern states such as Syria, Iran and Libya. Terrorism started to be understood as a foreign, mostly

178 Epps, 1979, 68.

179 Gilbert, 1991, 114. In addition to terrorists, Gilbert also contested that war criminals were testing the limits of the exception. See also Gilbert, 1991, 136.

180 Extradition requests to the US: prior to the 1970s, less than dozen; by 1978, about 100; by 1987,239 . Pyle has linked this development with the growth in international police cooperation. Pyle, 2001, 143.

181 Pyle, 2001, 144.

182 Cited in Schaefer, 1981, 634-635.

183 Reagan, 1986. 
Islamist phenomenon. Crimes committed by, for instance, the far right were not seen as terrorist. ${ }^{184}$

As discussed in the previous chapter, the growth of international terrorism had an important effect on Western policies, including those of the US. The first push had already come from the Munich Olympics attacks. Since the mid-1970s, Libya's growing role in international terrorism created alarm in the US. In 1976, the Office for Combating Terrorism was set up. The 1970s also laid the foundation for the future US policy of not negotiating with dealing terrorists. ${ }^{185}$

Even if terrorism seemingly was a new threat, the US actually had a long history of dealing with violent dissidents. According to Philip Jenkins, there had been a wave of domestic terrorist attacks in the US from 1973 to 1977 which did not generate a crisis. This period had witnessed atrocities committed by intelligence agencies, which resulted in public distaste for these organisations and scepticism with regard to the information they provided. ${ }^{186}$

Terrorism made its first appearance in US bilateral extradition treaties in 1978, when a new treaty with the Federal Republic of Germany (FRG, West Germany $)^{187}$ was signed. The treaty contained a new jurisdictional provision aimed at facilitating the combat against terrorism which allowed for extradition when the offence has been committed outside the territory of the requesting state by a national of the requesting state. ${ }^{188}$ However, terrorism was not excluded from the scope of the POE, even if the application of the exemption was limited by UN antiterrorist conventions. ${ }^{189}$

184 Jenkins, 2003, 38.

185 Fields, 1988, 282-283.

186 For instance in the 1920s, there was a terrorist wave in the US, known as the Red Scare. Bombings and bank robberies by anarchists and Communist militants were committed around the country. Jenkins, 2003, 33-36. See Jenkins, 2003, 61-66, for tables with domestic and international terrorist events in the US since the 1940s. See also e.g. Patterson, 2005, 71-73, for a discussion of the distrust of Americans in their security services and 76-107 for a general discussion on US domestic politics in the 1970s.

187 United States Extradition Treaty with the Federal Republic of Germany, 20 June 1978.

188 Letter of submittal, United States Extradition Treaty with the Federal Republic of Germany, 20 June 1978. Interestingly, the treaty between the FRG and Canada of 1977 did not contain such provisions. The only limitation to the POE in this treaty was the provision excluding attacks against internationally protected persons from the POE. Treaty Between Canada and the Federal Republic of Germany Concerning Extradition, E101275, CTS 1979 No. 18, 11 July 1977.

189 Article 4, para 3, "For the purpose of this Treaty the following offences shall not be deemed to be offences within the meaning of paragraph (1) [political offences]: (a) A murder or other wilful crime, punishable under the laws of both Contracting Parties by a penalty of at least one year, against the life or physical integrity of a Head of State or Head of Government of one of the Contracting Parties or of a member of his family, including attempts to commit such an offence, except in open combat; (b) An offence which the Contracting Parties or the Requesting State have the obligation to prosecute by reason of a multilateral international agreement." It has to be noted, however, that these legal documents have later been classified under UN antiterrorism conventions. United States Extradition Treaty with the Federal Republic of Germany, 20 June 1978. 
West Germany had ratified the European Convention on the Suppression of Terrorism of 1977 just one month before the signature of the US-FRG treaty. ${ }^{190}$ As West Germany had just recently committed to the suppression of terrorism and had its own terrorism problem, it seems likely that it would have been interested in giving more focus to the phenomenon in the treaty. The terrorism problem was not yet, however, of pressing concern to the US.

During the late 1970s and early 1980s, it eventually became clear that the nature of terrorism had changed. Cindy Schaefer wrote in 1981: "No longer are the victims limited to 'local tyrants, symbolic ambassadors, or errant politicians' whose deaths guaranteed publicity." The mass communication and mass transport systems made it possible to attract an unprecedented amount of attention to the deeds and to create an unparalleled amount of damage. The concept of perceived irrationality in the attacks was a new element. "Spectacular terrorism simply requires a willingness to take a disproportionate risk with lives" and these lives often included the terrorist's own life."191

Towards the end of the 1970s and in the early years of the 1980s, the US witnessed a growing amount of terrorist attacks targeting its own citizens. These included the Iranian hostage crisis of 1979, which gained worldwide attention. The rise of religious terrorism opposing the United States ${ }^{192}$ combined with the anti-Americanism of fundamentalist Muslims were presumably reasons why the United States became more interested in the global fight against terrorism. The Islamic revolution in Iran in 1979 provided an example to Muslims around the world, encouraging them to resist the advance of the West, especially that of the United States. ${ }^{193}$ In addition, the emergence of anti-American state-sponsored terrorism at the beginning of the 1980s and the unsuccessful (or even counterproductive) economic and military countermeasures against state sponsors of terrorism ${ }^{194}$ created more reasons for the US to participate in the then mainly European efforts of coordinating international collaboration against terrorism. ${ }^{195}$

The year 1983 emerged as the new high in terrorism against America. Over 250 people were killed in attacks against the American embassy and US Marine Headquarters in Beirut. The following years, international terrorist incidents increased by 30 percent in 1984 and by 45 percent in 1985. Most of these incidents included bombings. In 1985, there were 12 international terrorist incidents that involved US citizens. Two of these were highly publicised: the skyjacking

190 European Convention on the Suppression of Terrorism, ETS 90, 27 January 1977. See in more detail Section 4.1.5.

191 Schaefer, 1981, 634.

192 Hoffman, 1998, 93. However, it has to be noted that even in the 1980s and 1990s, the majority of terrorist incidents took place in areas not considered of special interest to the US. See more in Tilly, 2002.

193 Hoffman, 1998, 96; Patterson, 2005, 198.

194 In 1998, Cuba, Iran, Iraq, Libya, North Korea, Sudan and Syria. Hoffman, 1998, 191-192.

195 See e.g. Fields, 1988, 282. 
of the TWA flight 847 in June 1985 and the Achille Lauro affair in October the same year. ${ }^{196}$

In June 1985, two terrorists hijacked TWA Flight 847 travelling from Athens to Rome. The incident lasted for over two weeks, and during the course of the events, US Navy diver Robert Stethem was killed. The US sought the extradition of one of the hijackers but the Federal Republic of Germany decided to prosecute him instead. He was convicted of murder, hostage-taking, assault, and hijacking, and sentenced to life in prison but was released in 2005. ${ }^{197}$

Abraham Sofaer, a US judge and legal adviser to the State Department, suggested that the killing of Stethem, who was off duty, would not have been an extraditable offence. This was highly criticised by Christopher L. Blakesley who wrote that the "distinction between the killing of an off-duty, civilian-clothed military person during the hijacking of a civilian aircraft, and a firefight during a civil war seem significant enough for courts to distinguish."198

In the Achille Lauro case, four armed men of the Palestine Liberation Front (PLF) hijacked an Italian cruise ship of 400 passengers off the coast of Egypt. During the hijacking, an American passenger was murdered. The Egyptian government, unaware of the death of the passenger, let the perpetrators flee as a result of negotiations with the hijackers. Soon, American planes forced the Egyptian aeroplane with the terrorists on board to land. The plane landed in Italy, with which the US had an extradition treaty. The Italian government prevented the American representatives from boarding the Egyptian aircraft or arresting the perpetrators. When the United States requested the extradition of the said perpetrators, Italy assisted the perpetrators in fleeing to a safe haven in Yugoslavia, regardless of the conditions of the US-Italy extradition treaty. The attempts of the US to seek the extradition of the hijackers' commander, Mohammed Abbas, failed. The POE, however, was not invoked in the Italian refusal to extradite the hijackers. ${ }^{199}$

The US had established a counterterrorism policy that aimed at making sure terrorists would not escape justice, and the Achille Lauro case was the first one where it used military force to capture international terrorists. ${ }^{200}$ The case

196 Vice President's Task Force on Combatting Terrorism, February 1986. Fields, 1988, 286; Cassese, 1989, 55. According to Cassese, an estimated number of terrorist attacks around the world which involved "American officials, citizens or property" was as high as around 860. Cassese, 1989, 56. However, the definition must be paid attention to, as these attacks also involved crimes against property.

197 FBI History, Famous Cases and Criminals, https://www.fbi.gov/history/famous-cases/ hijacking-of-twa-flight-847, retrieved 27 February 2017. See contemporary news stories documenting the hijacking of the Trans World Airlines (TWA) jet from Athens. Trager (ed.), 1986, 68-73.

198 Blakesley, 1986, 123.

199 See in detail Cassese, 1989. See also Sofaer, 1986, 125; Allan, 1993, 334-336; Pyle, 2001, 273-274. See contemporary news stories documenting the Achille Lauro hijacking Trager (ed.), 1986, 82-87.

200 Fields, 1988, 285. 
has been seen as a symbol of all the problems that relate to the question of extradition. Interstate relations, even between countries of a common ideological and political background, or of a joint political or military alliance, can still result in decisions that contradict the common interest and allow national concerns to prevail. $^{201}$

Also in 1985, in December, yet another terrorist attack involving US citizens took place. Eighteen people, including 5 Americans, were killed and 114 wounded in terrorist incidents at the Rome and Vienna airports. ${ }^{202}$ All these events resulted in President Reagan ordering the setting of a new task force to combat terrorism. ${ }^{203}$

The following year, 1986, 2 American soldiers and a Turkish woman lost their lives and more than 200 others were wounded at the bombing of a disco in West Berlin. The bombing had been organised by the Libyan secret service and the Libyan Embassy in East Berlin, and the court that dealt with the case in 2001 referred to it as state-sponsored terrorism. As retaliation to the attack, President Reagan ordered airstrikes on the Libyan cities of Tripoli and Benghazi. ${ }^{204}$

Two months after the Berlin disco bombings, Reagan gave the following radio address: "History is likely to record that 1986 was the year when the world, at long last, came to grips with the plague of terrorism. For too long, the world was paralysed by the argument that terrorism could not be stopped until the grievances of terrorists were addressed. The complicated and heartrending issues that perplex mankind are no excuse for violent, inhumane attacks, nor do they excuse not taking aggressive action against those who deliberately slaughter innocent people." He continued, "Terrorists are always the enemies of democracy. Luckily, the world is shaking free from its lethargy and moving forward to stop the bloodshed." 205 The same year, a study was conducted that showed that Americans viewed terrorism as one of the most serious problems that the government had to deal with, equal to such issues as the budget deficit and strategic arms control. ${ }^{206}$

The decade of terrorism witnessed its most infamous attack in 1988, when Pan Am flight 103 was bombed over Lockerbie in Scotland. The attack resulted in the deaths of 270 people. The role of the Libyan government, namely Muammar Gaddafi, was not proven in the court case that followed, but his involvement in the event was presumed. The surrender of the Libyan men wanted for trial in Scotland was unsuccessful. Eventually, in 1992, the UN Security Council adopted

201 Cassese, 1989, 145.

202 See e.g. L.A. Times, 27 December 1985, "16 die in terrorist attacks at Rome, Vienna airports: 117 hurt in raid aimed at Israeli." See more contemporary news stories covering the Rome and Vienna airport attacks Trager (ed.), 1986, 103-105.

203 Fields, 1988, 286. Vice President's Task Force on Combatting Terrorism, February 1986.

204 See e.g. Fields, 1988, 285; Erlanger, 2001. See contemporary news stories covering the bombing at a disco in West Berlin Trager (ed.), 1986, 109.

205 Reagan, 1986.

206 Vice President's Task Force on Combatting Terrorism, February 1986. 


\section{Taking the political out of the political}

Resolution 731, calling on Libya to accept the joint request by the United States, United Kingdom and France for the surrender. ${ }^{207}$ As Libya failed to return the men, the UN passed two other resolutions which imposed mandatory sanctions on Libya in 1992 and $1993 .^{208}$

Concurrently with the rise of the terrorist threat, there was also a notable rise in the number of extradition requests to the US that related to the use of the POE. ${ }^{209}$ The protection of pure political offenders had continuous public support, but an increasing amount of debates concerned the application of the POE to relative political crimes. ${ }^{210}$ Echoes of the old Whig-Tory division in the Anglo-American context could be seen in the debates concerning the POE. The traditional Whig perspective was that courts of liberal republics should be neutral with regard to foreign rebellions. This reflected the Lockean view of the right to revolt. ${ }^{211}$ According to this view, most political criminals deserved protection from being extradited to regimes they had risen against. The Tory perspective, in turn, was critical of rebellions. According to this outlook, nations with similar ideologies should support each other in suppressing revolutions. ${ }^{212}$ Christopher H. Pyle has written: "For the Whigs who championed the political offence exception during the mid-nineteenth century, the image that inspired their law-making was of liberal revolutionaries who fought militarily (like Bolivar, Mazzini, and Kossuth) to overthrow autocracies that the Whigs despised. For the Tories who subsequently sought to limit the exception, the image that provoked their lawmaking was of radical socialists, anarchists, war criminals, and terrorists whose political hatreds were not admired and whose attacks recklessly or deliberately killed bystanders." 213

\subsubsection{The POE loses its justification}

As discussed, the first push towards a stricter approach against terrorism came after the American embassy hostage crisis in Iran in 1979. President Jimmy Carter failed in his attempts to resolve the crisis, which fuelled the victory of Reagan in the wake of the incident in 1981. Like Carter, also President Ronald Reagan

207 UN Security Council Resolution on Libyan Arab Jamahiriya, S/RES/731, 21 January 1992.

208 See e.g. Boyd, 2001; and Emerson, 2004.

209 Lieberman, 2007, 191.

210 Lampo, 1988, 247-248.

211 See for a historical account of the 'right to revolt' or the 'right to resistance' e.g. Kälin and Künzli, 2000, 47-50; De Benedictis, 2001, 307-327. See also paragraph 3 of the preamble to the UDHR, stating that "Whereas it is essential, if man is not to be compelled to have recourse, as a last resort, to rebellion against tyranny and oppression, that human rights should be protected by the rule of law [...] the General Assembly proclaims this Universal Declaration of Human Rights." See for a commentary Kälin and Künzli, 2000, 51-52.

212 Pyle, $1988,181$.

213 Pyle, 2001, 141. 
swore his devotion to the battle against terrorism. ${ }^{214}$ However, the Carter administration had underlined its dedication to the promotion of international human rights, while, in January 1981, the Reagan administration's Secretary of State Alexander Haig (1981-1982) made a public statement that the battle against international terrorism would overrule human rights concerns "because it is the ultimate abuse of human rights." 215 Notwithstanding its commitment to fighting terrorism, the Reagan administration was reluctant to introduce a definition of the term. ${ }^{216}$

The new administration was convinced that the POE was a legal loophole terrorists could use and sought to close it. ${ }^{217}$ The POE had never fit well with US traditions, but its humanitarian basis had appealed to the state. However, the rule of non-inquiry to the motives behind the requests applied by US courts undermined the humanitarian element of the exemption, which made it more difficult to justify. ${ }^{218}$ The application of the POE proved even more difficult when it became obvious that its traditional application by the US courts protected socalled terrorists.

The Reagan administration started a campaign against the POE. Attention was drawn to the POE as a number of violent offenders had managed to escape justice due to the courts' application of the exemption. The most publicised of these cases concerned members of the IRA and strained the USUK relationship. The establishment of the Office of International Affairs (OIA) in the Department of Justice Criminal Division in 1979 had made it easier for federal and state prosecutors to seek extradition for offenders fleeing the country. The office's collaboration with foreign authorities also raised the willingness of other states to cooperate with the US in extradition matters. ${ }^{219}$

In 1982, the Reagan administration sought to reform the Extradition Act and exclude a variety of offences from the scope of the protection, in line with the European Convention of the Suppression of Terrorism of 1977. The Senate bill issued provided that unless circumstances were extraordinary, violent crimes, including homicide, rape, kidnapping, taking hostages and the use of firearms, ought not to be considered political offences. The House bill provided that crimes of "wanton or indiscriminate" violence should be exempted from the protection of the POE. The outspoken purpose of these additions was to better enable the combatting of terrorism. However, the list of excluded offences in the ECST was much shorter than the one proposed in the Senate bill. Additionally, the ECST was subject to reservations, which in practice safeguarded the POE. The Senate

214 Fields, 1988, 285; Patterson, 2005, 125-126.

215 Trager (ed.), 1986, 206. See contemporary press commentaries on the changes in US foreign policy during Reagan's early years in office Trager (ed.), 1986, 206-215.

216 Friedlander, 1988, 11.

217 Pyle, 2001, 198.

218 Pyle, 2001, 81.

219 Abbell, 2010, 15-16. 


\section{Taking the political out of the political}

bill still suggested to leave the decision-making concerning the application of the POE to the judiciary but provided guidelines for its application. ${ }^{220}$

The legislation was never put into place, as Congress had concerns over its implications. The legislation would have made all killings extraditable, including those occurring during rebellions and for a rebellious cause. This meant that also those who maimed despotic leaders, or fought for a friendly regime that was later overthrown, would have been extradited. ${ }^{221}$

Banoff and Pyle argued in 1984 that these limitations would essentially have meant the evisceration of the POE. ${ }^{222}$ As the bill did not define what constituted a political offence, the courts would have been likely to proceed with the application of the political uprising test laid down in 1894 in the In re Ezeta case. As the Ezeta requirement was that the defendant ought to have participated in a revolution or other violent political disturbance, a requirement that no weapons could be used and no deaths caused, and no prisoners taken for this purpose seemed to exclude all offences previously understood as political offences from the scope of the exemption. Or almost all: "While the line between terrorism and wars of liberation may, on occasion, be difficult to draw, the proposed statute appears to draw that line at pillow fights." ${ }^{223}$ Further, Banoff and Pyle expressed their concern that "In the Administration's rush to condemn terrorism, the human rights concerns inherent in the concept of political asylum have been largely ignored." 224

It soon proved impossible to remove the POE from US legislation. Instead, the Reagan administration turned its hopes to eliminating the POE from all US extradition treaties. As this proved unworkable, it made an attempt to abolish it treaty by treaty. As this attempt also failed, the administration wished to "persuade the courts to interpret it out of existence" or, optionally, to make its application an executive rather than a judiciary decision. The administration attacked the courts for being too soft on terrorism, as proven by the decisions in the Artukovic case and the cases of IRA members who had committed violent acts, as well as in the delays in the extradition of Eain. For this reason, it was claimed, courts could no longer be given the right to apply the POE. ${ }^{25}$

As the reform of the Extradition Act was unsuccessful, other means to close loopholes in the POE letting terrorists through were created. In 1986, the Omnibus Diplomatic Security and Anti-Terrorism Act was passed by the US Congress. President Reagan saw that the act constituted a forward step in the "bipartisan effort to eradicate international terrorism." The act spelt out the US dedication to the need for an international convention for the prevention and

220 Banoff and Pyle, 1984, 171; Pyle, 2001, 200.

221 Lampo, 1988, 245.

222 Banoff and Pyle, 1984, 194. Sometimes the attentat clause has been interpreted more widely, for instance so that it also covers diplomatic representatives. Stanbrook and Stanbrook, 2000, 82 .

223 Banoff and Pyle, 1984, 190.

224 Banoff and Pyle, 1984, 172.

225 Pyle, 2001, 146. 
control of all aspects of terrorism. ${ }^{226}$ In 1986, the Vice President's Task Force on Combatting Terrorism hoped for a revision of extradition treaties "with countries with democratic and fair judicial systems to ensure that terrorists are extradited to the country with legal jurisdiction." 227

Regardless of the changes in US policies concerning extraditions, the extradition treaties the US entered in the 1980s continued to contain the typical, unlimited POE or the POE with the attentat clause. ${ }^{228}$ The discrimination clause was first introduced to US bilateral extradition treaties in the 1983 treaty with Jamaica, ${ }^{229}$ but never became a common feature of US extradition treaties. The US-Italy treaty from the same year contained the POE and the limitation that concerned obligations with regard to multilateral conventions to which both countries were parties to. A particularity of the treaty was a detailed attentat clause. The clause specified that

an offence against the life, physical integrity or liberty of a Head of State or Government or a member of their respective families, or any attempt to commit such an offence, will be presumed to have the predominant character of a common crime when its consequences were or could have been grave. In determining the gravity of the offence and its consequences, the fact that the offence endangered public safety, harmed persons unrelated to the political purpose of the offender, or was committed ruthlessness shall, in particular, be taken into account. ${ }^{230}$

Similar to the US-Brazil treaty of 1961 and the US-Argentina treaty of 1972, the US-Italy treaty also considered the predominance of the common crime element of the crime in question. Thus the model of the Swiss predominance test was brought to the treaty text itself. This left room for the court to determine whether the "consequences [of the act] could have been grave" and with regard to the "ruthlessness" of the crime but seems to categorically provide for the exclusion of terroristic offences from the scope of the protection of the POE.

This new treaty with Italy reflected a 'fixing of loopholes' approach in bilateral treaties. The United States had completed a previous treaty with Italy only ten years earlier. This treaty did not explicitly refer to the 1971 Montreal Convention, but it limited the POE with a clear reference to the it: "For the purposes of the

226 Friedlander, 1988, 16-17.

227 Vice President's Task Force on Combatting Terrorism, February 1986.

228 See e.g. Article 4, Treaty on Extradition between Ireland and the United States of America, 13 July 1983; Thailand International Extradition Treaty with the United States, 14 December 1983. The Belgium-US treaty also excluded the attempt or conspiracy to kill or otherwise target a head of state. Article 4, Convention d'extradition entre le Royaume de Bélgique et les Etats-Unis d'Amérique, 27 April 1987.

229 Jamaica International Extradition Treaty with the United States, 14 June 1983.

230 Article 5 (2), Extradition Treaty between the Government of the United States of America and the Government of the Republic of Italy, 13 October 1983. 
application of the present paragraph, the seizure or exercised of control by force or violence or threat of force or violence committed on board an aircraft in flight carrying passengers in scheduled air services or on a charter basis will be presumed to have a predominant character of a common crime when the consequences of the offence were or could have been grave."231 This approach where bilateral treaties were edited as the terrorist threat grew bigger, demonstrates the turbulence in this field of law during the 1970s and 1980s.

\subsubsection{US-UK controversies with regard to terrorism in the 1980s}

One of the most important US reforms that concerned the POE and terrorism was the 1985 revised extradition treaty with the United Kingdom. The revision of the treaty was a reaction to controversies between the US and the UK with regard to the US courts categorically denying extradition to revolutionary members of the Provisional Irish Republican Army (PIRA), offenders that the UK considered terrorists. ${ }^{232}$

In fact, since the 1860 s rebellions in Ireland, the United States had not granted extradition to a single Irish political resistor to the United Kingdom. ${ }^{233}$ The rejection was validated with the incidence test applied since the late 1800s. There was undeniably an ongoing political disturbance in Northern Ireland and PIRA's violent attacks were incidental to its political objectives. Thus crimes by the PIRA were considered of political nature, which in turn made them non-extraditable. ${ }^{234}$

During the 'Troubles' in Northern Ireland, Irish rebels gained an important share of their financial backing from the US as well as private individuals and groups. Due to the important majority of Irish descendants in the US, it was politically difficult for the US to take a stance against the Irish Republican Army (IRA) or the PIRA. ${ }^{235}$ However, due to the importance of US-British political

231 Article 6, Treaty on Extradition between the United States of America and Italy, 18 January 1973.

232 See on the history of the conflict and politics in Northern Ireland and the PIRA e.g. Moxon-Browne, 1981, 148-163; Hogan and Walker, 1989; Greer, 1995; Aughey and Morrow, 1996; English, 2003; Dingley, 2012.

233 Kulman, 1986, 775; McElrath, 2000, 8. See also Gilbert, 1991, 125; Gilbert, 1998, 229. See in more detail on the history of political violence in Ireland and Northern Ireland e.g. Hogan and Walker, 1989, 7-18. McElrath has done extensive research on US policies with regard to Irish fugitives throughout the last 200 years. The policies have varied according to political interests and personal preferences in the US administration. See in more detail McElrath, 2000.

234 See e.g. Banoff and Pyle, 1984, 170; Gilbert, 1985, 699; Kulman, 1986, 767; Groarke, 1988, 1515; Lieberman, 2007, 192. It is noteworthy that the same thing was happening with the Republic of Ireland as well. Irish courts considered the violence in Northern Ireland as political, and thus the offenders accused of terrorism by the UK were protected by the POE. Gilbert, 1991, 117; Gilbert, 1998, 212.

235 Jenkins, 2003, 23. See also e.g. McElrath, 2000, 120-121; English, 2003; Dingley, 2012. 
relations, the support was not given openly and the US administration sought to remain neutral vis-à-vis the Irish cause. ${ }^{236}$

The US take on the matter was in stark contrast with the British view. In 1976, the British had started to treat the conflict in Northern Ireland as an internal security problem, instead of an insurgency that required a military solution. This meant introducing new counterterrorist legislation and treating insurgents as criminals instead of prisoners of war. ${ }^{237}$ The criminalisation of the IRA's activities produced miscarriages of justice. ${ }^{238}$

The US was forced to change its political position after two IRA attacks that occurred in 1979, one killing Lord Mountbatten and 3 others, and another killing 18 British soldiers in an explosion at army barracks. The Carter administration essentially showed its support to British policies in Northern Ireland in remaining "neutral" towards the situation, and officially declaring its trust in the British holding on to human rights. ${ }^{239}$

During this period, the US started to deport, deny access to the country and extradite political criminals. This historical policy did not only concern Irish political offenders, but became a general US policy. ${ }^{240}$ However, the changes in the administration's position were not instantly mirrored in courts.

Amongst the most important of the US cases that concerned members of the IRA were the Mackin and McMullen cases. ${ }^{241}$ In the McMullen case $(1979)^{242}$ the US court deemed the bombing of military barracks by IRA member McMullen a political offence and denied extradition. Similarly, in the Mackin case $(1981)^{243}$ a US court invoked the protection of the POE for an attempted murder of a plainclothes intelligence British patrol soldier.

The McMullen case was the first where a US court had to consider whether terrorism was a legitimate political tactic and whether it could be protected by the political offence exemption. ${ }^{244}$ The decision outraged some of the officials

236 McElrath, 2000, 12-16.

237 Groarke, 1988, 1533; Pyle, 2001, 154; Shanahan, 2008, 95-96, 225. See in more detail e.g. Bonner, 1988.

238 Shanahan, 2008, 95-96, 225. The new legislation included the Northern Ireland (Emergency Provisions) Act of 1978 ("EPA") and the Prevention of Terrorism (Temporary Provisions) Act of 1984 ("PTA"). See in more detail e.g. Freestone, 1981, 197-199; Groarke, $1988,1533$.

239 McElrath, 2000, 16-18.

240 See in more detail the changes in US immigration controls during this period McElrath, $2000,21-44$.

241 Lubet, 1982, 256. See McElrath, 2000, 33-44, for other cases concerning extraditions and deportations of Irish political criminals from the US.

242 In the Matter of the Extradition of Peter Gabriel John McMullen, Magistrate No. 3-781099 MG (N.D. Cal., 11 May 1979). See in detail e.g. Hannay, 1980, 398-402; Schlaefer, 1981, 637-638; McElrath, 2000, 47-48; Pyle, 2001, 152-155. See for personal background of McMullen, Pyle, 1988, 191; and Pyle, 2001, 152-155.

243 In re Mackin, 668 F.2d 122 (2d Cir. 1981). See in detail e.g. McElrath, 2000, 46-47. See for the personal background of Mackin, Pyle 1988, 192; Pyle, 2001, 170-175.

244 Hannay, 1980, 391. 
of the Carter administration, who had openly declared a war on terrorism. The protection of McMullen as a political offender was seen as unacceptable, as some considered him a terrorist. The McMullen case was one of the decisions that fuelled the calls to change the law. ${ }^{245}$ As a result, the US Justice Department began its campaign to abolish the POE. ${ }^{246}$ McMullen was extradited in 1996 and was sentenced to 14 years of imprisonment. ${ }^{247}$

In the case of Mackin, incriminating evidence was lacking, but Mackin was repeatedly and publicly called a terrorist by the US Justice Department. At the same time, pro-IRA groups in the US considered him a hero. According to Christopher H. Pyle, the Mackin case was just the type of case for which the POE had been originally developed. ${ }^{248}$

Regardless of the outcome of the extradition case, the Immigration and Naturalisation Services of the US decided to deport Mackin. As the deportee can decide his or her own destination, Mackin ended up in Ireland. The UK never requested his extradition. According to McElrath, this was most likely due to the fact that his extradition would not have been granted because of the political nature of the crimes. ${ }^{249}$

The rejection of the extradition request proved politically problematic, as the court ruled that the IRA was a disciplined and highly organised guerrilla army and not a group of terrorists. Simultaneously, Prime Minister Margaret Thatcher, an ally to the new Reagan administration, ${ }^{250}$ considered the violent attacks by the IRA as terroristic and was under great pressure end the violence. ${ }^{251}$ Magistrate Buchwald, upon deciding the case, underlined the importance of not creating safe havens for terrorists in the US, but still viewed Mackin's crimes as relative political offences, instead of offences committed for personal motivations. ${ }^{252}$ Magistrate Buchwald concluded that Mackin's actions were aimed against a soldier and they followed the logic of the traditional goals and strategies of the IRA. Magistrate Buchwald did not evaluate whether the discrimination clause could have been applied to the Mackin case. ${ }^{253}$

The American courts' application of the POE in the McMullen and Mackin cases caused political worry. Some were convinced that using a similar approach to other terrorist cases could turn the country into a safe haven for fugitive terrorists. This would have not only compromised national security but also negatively

245 Pyle, 2001, 154.

246 Pyle, 2001, 160.

247 McElrath, 2000, 57.

248 Pyle, 2001, 171.

249 McElrath, 2000, 47.

250 See e.g. McElrath, 2000, 18, 51; and Lundestad, 2003, 213.

251 Pyle, 2001, 171-173.

252 N.Y. Times, 16 August 1981, "I.R.A. member wins extradition case in U.S." See also Pyle, 2001, 173.

253 Pyle, 2001, 173-174. 
affected the country's foreign relations. ${ }^{254}$ The cases were seen to prove that the POE had been outdated. As a result, the US saw a need to revise the laws and treaties so that they would no longer protect terrorists, but at the same time would safeguard the protection for 'legitimate dissidents. ${ }^{255}$ The terrorist cases raised both scholarly and political discussion on the concept of the POE and of the domestic extradition process of political offenders as discussed above.

In addition to the cases In re McMullen and In re Mackin, the US also denied extradition in the case of In re Doberty (1984). ${ }^{256}$ Doherty was a member of the PIRA accused of the murder of a British army captain when attacking a convoy of British soldiers in Northern Ireland. ${ }^{257}$

In the Doberty case, the court, after a thorough consideration of the history and nature of the PIRA, came to the conclusion, similar to the Mackin and McMullen decisions, that the PIRA had "both an organisation, discipline, and command structure that distinguishes it from more amorphous groups such as the Black Liberation Army or the Red Brigade." For these reasons, Doherty's offences were political and his extradition was denied. The court discussed whether the crimes were purely political because no civilians were maimed in the attack. Finally, the court also concluded that a seemingly political crime could also be excluded from the scope of the POE if it became clear that personal reasons were the main motivation for the crime. ${ }^{258}$

The British and American governments made an effort to portray Doherty as a terrorist and a criminal instead of a paramilitary, and to depict the British role in Northern Ireland as law enforcement. The Doberty case was the first where a federal judge tried to estimate whether the accused could receive a fair trial upon his return. Judge Sprizzo set a precedent by arguing that if evidence demonstrated clear injustices in the courts of the requesting regime, extradition would not be allowed. The decision, which was in line with precedents denying extradition, was highly debated. It provoked more discussions on the need to eliminate the POE. Margaret Thatcher took a personal stand against the decision, which was made the same year as the IRA attacked her and her cabinet, killing altogether eight people. ${ }^{259}$

The Doberty decision confirmed the wanton crimes exception which was endorsed by Judge Sprizzo. Additionally, it strengthened the humanitarian function of the POE, as Sprizzo examined the ability of Northern Irish courts to

254 Banoff and Pyle, 1984, 170.

255 Lubet, 1982, 247-248.

256 In re Doberty, 599 F. Supp. 270 (S.D.N.Y. 1984).

257 See in more detail e.g. Kulman, 1986, 767; Sapiro, 1986, 655; Lampo, 1988, 246-247; Pyle, 2001, 175-181.

258 In re Doherty, 599 F.Supp. 270 (S.D.N.Y. 1984). See also e.g. Kulman, 1986, 767; Sofaer, 1986, 130; Noone and Alexander, 1997, 90-95; Piemonte, 2013, 626. See for the personal background of Doherty e.g. Pyle, 1988, 192-193.

259 Pyle, 2001, 179-182. See contemporary news stories covering the attack against the UK Conservative Party Conference in 1984. Trager (ed.), 1986, 152-155. 
provide a fair trial. In doing so, the judge breached the traditional rule of noninquiry and claimed judicial administration of the discrimination clause. ${ }^{260}$

The same strictness in the interpretation of the incidence test that had protected Doherty resulted in the extradition of William Quinn in Quinn v. Robinson. ${ }^{261}$ Quinn, a US citizen, was wanted by the UK for the murder of a police constable, conspiracy to send explosive devices through the mail, and conspiracy to cause a number of explosions in which a security guard and a crown court judge were injured. Quinn later became the first IRA member to have been extradited to Northern Ireland. His extradition was first denied by the District Court based on the POE. Later, however, the Ninth Circuit Court allowed for his extradition, concluding that the crime had taken place in England rather than in Northern Ireland where the political uprising existed. Thus Quinn's crimes ensued in a different location than the Republican rebellion. This was the sole reason the court accepted the extradition. ${ }^{262}$ Abraham Sofaer called this decision 'remarkable':

Thus, Quinn merely chose the wrong location for his acts. Under the Quinn decision, he, and other PIRA terrorists, would be free to murder and bomb without losing the potential benefits of the political offence exception, as long as they did so in Northern Ireland. ${ }^{263}$

Also, Lieberman has pointed out that the geographical limitation is a forced interpretation and could limit the POE in unwanted ways. ${ }^{264}$

However, as noted by Kathleen Basso, the statement could be read with the emphasis on the words "own government." The court questioned whether the protection given by the POE should apply even when the accused was not a citizen of the location of the uprising. She has pointed out that the original purpose of the POE was not to protect volunteers in foreign conflicts, but rather revolutionaries battling against oppressive regimes. ${ }^{265}$

Quinn's crimes could potentially have also fulfilled the wanton crimes limitation. ${ }^{266}$ Interestingly, the court had acknowledged the status of Quinn as a political criminal. Quinn had been imprisoned in Ireland as a "special category prisoner," a status equivalent to that of a prisoner of war. McElrath has criticised the decision for being illogical, as the court, with this acknowledgement, seemed

260 Pyle, 2001, 183.

261 Quinn v. Robinson, 783 F.2d 776, 783 (9th Cir. 1986).

262 See in more detail e.g. Murphy, 1985, 51-52; Kulman, 1986, 768; Sofaer, 1986, 129; Lampo, 1988, 246; Pyle, 1988, 194-195; Noone and Alexander, 1997, 95-102; McElrath, 2000, 48-50; Pyle, 2001, 158-164.

263 Sofaer, 1986, 130.

264 Lieberman, 2007, 198.

265 This argument had earned support from at least two US court decisions. Kjar v. Doak, 61 F.2d 566 (7th Cir. 1932); United States v. Tapolcsanyi, 40 F.2d 255 (3d Cir. 1930). Basso, $1989,329$.

266 Pyle, 1988, 194. 
to accept that the conflict extended to Southern Ireland. This was in contrast with the McMullen case, where the POE was applied even if the acts took place on British soil. ${ }^{267}$

The decision, and the incidence test in general, drew the judges' attention away from the individual to the political circumstances that surrounded them. ${ }^{268}$ For this reason, the incidence test is sometimes seen as a more neutral way to apply the POE. However, the strict application of the incidence test also made the judges lose the possibility to make nuanced decisions. ${ }^{269}$

In allowing Quinn's extradition, the court limited the concept of political uprising. It defined 'uprising' as “a revolt by indigenous people against their own government or an occupying power." Thus, the POE was limited to protecting those whose field of action was inside the borders of the specific geographical area in which the struggle for political power was taking place. ${ }^{270}$

The court in Quinn applied what it called a 'liberal' standard of the political incidence test, necessitating "neither proof of the potential or actual effectiveness of the actions in achieving the group's political ends $[\ldots]$ nor proof of the motive of the accused." The aim was to objectively determine the nature of the crime and thus unify the applications of the political incidence test. ${ }^{271}$

The Quinn decision has been criticised as "incoherent."272 According to Murphy, the decision was correct in establishing that the shooting of a police constable was a political offence. However, the planting of bombs targeting civilians would also in times of armed conflict be considered criminal. For this reason: "That the violence directed against the general civilian population was incidental 'to the political goals of seeking an end to British rule in Northern Ireland,' a factor cited by the court in support of its decision in Quinn, seems clearly inconsistent with the ruling in Abu Eain." 273 Thus, it seems that also Murphy promoted the wanton crimes exception. According to Pyle, Quinn's surrender reflected the decreasing support for the Irish cause within the US government and judiciary and did not follow due process of law. ${ }^{274}$

\subsubsection{Creation of the Supplementary Treaty of 1985}

The categorical refusal of extradition of wanted terrorists resulting from the strict application of the political incidence test created a public outcry, with some arguing that the United States had become a safe haven for terrorists. It also weighed heavily on the US-UK relationship. The political pressure resulted in a

267 McElrath, 2000, 49.

268 Lieberman, 2007, 192; Piemonte, 2013, 624.

269 Lieberman, 2007, 192.

270 Lieberman, 2007, 197-198; Piemonte, 2013, 624.

271 Cited in Piemonte, 2013, 625.

272 Pyle, 2001, 159.

273 Murphy, 1985, 52.

274 Pyle, 2001, 164. 


\section{Taking the political out of the political}

supplementary extradition treaty being drawn between the United States and the United Kingdom. ${ }^{275}$ As the Irish influence on the Democratic Party lessened in the 1970s and 1980s, it became easier to enhance collaboration with the UK. ${ }^{276}$ Additionally, the creation of the PIRA had provoked a change in Irish republican policies which, in turn, affected US policies. The British claimed that the PIRA received support from Communist states and had ideological links to Marxism. As a result, Communism being the US ultimate enemy, the Irish republican cause received less support from the country. ${ }^{277}$

The terrorist attacks during the first part of the 1980s that had killed and wounded US citizens started to affect the way in which the international extradition process was viewed by Americans. "Crime as an extension to politics" came all too close to the interests of the country.

The US-UK extradition treaty of $1972^{278}$ that had not restricted the POE at all caused political worry. ${ }^{279}$ It was patched up with the 1985 Supplementary Treaty, which limited the POE in a drastic way. ${ }^{280}$ According to the Reagan administration, the aim of the treaty was to improve the combatting of international terrorism by limiting the scope of the POE and close the loopholes that let terrorists escape justice. ${ }^{281}$

The new treaty was partly modelled on the European Convention on the Suppression of Terrorism of 1977, which the United Kingdom had ratified in 1978. ${ }^{282}$ The creation of the treaty was fuelled by the attempted assassination of British Prime Minister Margaret Thatcher in 1984. The final push to the creation of the treaty was the UK support for the US attacks against Libya, which made it politically difficult to not accept the suggested treaty. ${ }^{283}$ One of its aims was to retroactively allow the extraditions of McMullen and Doherty. ${ }^{284}$

The contents of the treaty resembled that of the planned and failed US Extradition Act of 1982. As many extradition treaties since the US-West Germany

275 McElrath, 2000, 49.

276 Pyle, 2001, 218.

277 McElrath, 2000.

278 Extradition Treaty between the Government of the United Kingdom of Great Britain and Northern Ireland and the Government of the United States of America, 8 June 1972.

279 Article 5, Extradition Treaty between the Government of the United Kingdom of Great Britain and Northern Ireland and the Government of the United States of America, 8 June 1972.

280 Supplementary Treaty between the Government of the United Kingdom of Great Britain and Northern Ireland and the Government of the United States of America signed at Washington on 25 June 1985 as amended by an Exchange of Notes signed at Washington on 19 and 20 August 1986 concerning the Extradition Treaty signed at London on 8 June 1972 with an Exchange of Notes concerning Hong Kong, 23 December 1986.

281 See e.g. Kulman, 1986, 755, 775; Petersen, 1992, 767.

282 European Convention on the Suppression of Terrorism Strasbourg, 27 January 1977, ETS No. 90; Petersen, 1992, 781.

283 Pyle, 2001, 202.

284 Pyle, 2001, 204. 
treaty of 1978, it incorporated the recent UN conventions by narrowing the protection of the POE, so that it would not cover crimes one of the parties had an obligation to extradite or prosecute based on their multilateral treaty obligations. The 1985 Supplementary Treaty also categorically excluded a long list of offences from the scope of protection of the POE, with the wording "none of the following shall be regarded as an offence of a political character. " 285 In other words: "the Supplementary Treaty provides that all fugitives accused of committing violent acts can be extradited even if their acts are politically motivated." 286 Bradley G. Kulman has called this "depoliticisation" of these mentioned crimes. ${ }^{287}$ More specifically, this can be seen as a way to depoliticise the treatment of these crimes, not of the crimes themselves. The political motivation of the crimes did not need to be denied for them to be extraditable.

The offences excluded from the POE in the 1985 treaty concerned crimes such as murder, assault causing grievous bodily harm, kidnapping, offences "involving the use of a bomb, grenade, rocket, firearm, letter or parcel bomb, or any incendiary device if this use endangers any person" and aiding and abetting to these crimes. ${ }^{288}$

The mandatory extradition was limited by the discrimination clause, a rarity in US extradition treaties, allowing the competent judicial authority to deny extradition in a case where the fugitive could persuade them that the extradition request was made "with a view to try or punish him on account of his race, religion, nationality, or political opinions, or that he would, if surrendered, be prejudiced at his trial or punished, detained or restricted in his personal liberty by reason of his race, religion, nationality or political opinions." ${ }^{289}$ It is clear that this provision was in contrast with the rule of non-inquiry that bound the US courts and it is quite interesting that it was added to a treaty joining together two close allies with highly similar legal systems.

The adoption of the discrimination clause was a reaction to the vast amount of criticism the US-UK treaty received. According to Pyle, it was not expected

285 Article 1, US-UK Supplementary Treaty of 1985.

286 Groarke, 1988, 1516. Italics added.

287 Kulman, 1986, 756.

288 Some crimes that were included in the draft treaty were left out from the final version, such as a conspiracy to cause explosions, "possession or making of an explosive substance by a person who intends to endanger li[ves]" strongly criticised by for instance Kuhlman. He noted, "As these are intent crimes, the requesting state must produce some evidence that the accused possessed the requisite intent." Kulman, 1986, 781. It has to be noted that these kinds of intent crimes have later been criminalised in European context. Additionally, the draft included the crimes such as the possession of a firearm when a person intends to "endanger life" and the use of firearms by a person who intends to resist or prevent the arrest of himself or another person. These kinds of broad and unspecific clauses were criticised by many. One criticism stated that the ownership of a firearm could not in itself prove malicious intent. Kulman, 1986, 781. As a result, none of these provisions were included in the final treaty.

289 Article 3, US-UK Supplementary Treaty of 1985. 


\section{Taking the political out of the political}

to be used by an extradition court. ${ }^{290}$ Additionally, the burden of proof over receiving unfair treatment upon extradition lay with the accused. It was not considered enough evidence that the requesting state, for instance, used torture, but the fugitives had to show that they themselves were in jeopardy to face torture, should they be returned. ${ }^{291}$ The discrimination clause was, in fact, applied by the US District Court for the Northern District of California in the case of Smyth in 1993. ${ }^{292}$ However, the decision was overruled by the Court of Appeals. Smyth had been convicted of the attempted murder of a prison officer in Belfast, Northern Ireland, in 1978. He was sentenced to 20 years' imprisonment. He escaped prison in 1983 and landed in San Francisco. He was sought by Northern Ireland to serve the remainder of his prison term. The Ninth Circuit Court of Appeals concluded that there was not enough evidence to show that Smyth would receive retaliatory punishment upon his return or be otherwise treated in a discriminatory manner. ${ }^{293}$

After the Supplementary Treaty was drawn, McMullen, whose extradition had been denied seven years earlier, was finally extradited in 1986. The basis for the extradition was that the persecution McMullen had claimed to suffer if extradited, did not relate to his political opinions. McMullen had claimed that his collaboration with the US officials upon arrival to the country had made him a traitor in the eyes of the PIRA. Additionally, the court stated that asylum could not be granted, as it was reasonable to believe he had committed serious crimes of non-political character. ${ }^{294}$ It is interesting that the court applied asylum law in its decision, while previously McMullen had been protected by the POE.

\subsubsection{Evaluating the 1985 treaty}

The Supplementary Treaty of 1985 excluded from the scope of the POE offences that were, as Kulman pointed out, "often highly publicised acts, likely to arouse public indignation in the requesting state." Refusing to extradite criminals accused of such acts, would no longer have been seen as politically neutral. ${ }^{295}$ The treaty was seen to put an end to similar cases to the ones involving the PIRA, which resulted in non-extradition. ${ }^{296}$

290 Pyle, 1988, 188. See also Dugard and Van den Wijngaert, 1998, 190.

291 Pyle, 2001, 203-204.

292 Extradition of Smyth 820 F. Supp. 498 (N.D. Cal. 1993).

293 In re Requested Extradition of Smyth, 61 F.3d 711 (USCA, 9th Cir., 1995).

294 "The BIA [The Board of Immigration Appeals] also found that McMullen was statutorily ineligible for asylum as a refugee under section 101(a)(42)(A), 8 U.S.C. Sec. 1101(a) (42)(A), which excludes from refugee status; any person who ordered, incited, assisted, or otherwise participated in the persecution of any person on account of race, religion, nationality, membership in a particular social group, or political opinion." See 788 F.2d 591, USCA 9th Circ. McMullen v. Immigration and Naturalisation Service, No. 84-7468, 25 April 1986.

295 Kulman, 1986, 779.

296 Kulman, 1986, 777. 
Christopher L. Blakesley noted that crimes excluded from the scope of the treaty were crimes that terrorists commit against 'innocent' civilian targets. However, simultaneously, some of these crimes were also such that the winning side of a civil war or insurrection could prosecute, even if they took place in open battle against military targets. The categorical exclusion of such crimes from the POE removed the decision-making from the courts. As a result, it exempted the courts from deciding under which conditions the crimes actually occurred, as well as whether the conduct, for instance, constituted self-defence. Regardless of his criticism, Blakesley was supportive of limiting the coverage of the POE for certain types of violent crimes but recognised that the POE provided for such exclusions in itself. ${ }^{297}$

Since the adding of the POE into US extradition treaties in the mid-19th century, extradition decisions had always been in the hands of the judiciary. ${ }^{298}$ In addition to making drastic limitations to the POE, the Supplementary Treaty of 1985 also narrowed this role. ${ }^{299}$ Similar limiting provisions had, however, already been included in the 1979 treaty with Colombia ${ }^{300}$ and the 1980 treaty with the Netherlands, ${ }^{301}$ both of which allowed the executive decision-making powers concerning the application of the POE and the military offences exceptions.

The narrowing of the role of the judiciary was widely discussed amongst policymakers and academics. Some supported it, as they considered the judiciary incapable of making a separation between acts of wanton terrorism and political offences, ${ }^{302}$ even if the wanton crimes exception had recently started to receive support in the US courts. ${ }^{303}$ Some argued that the determination of the political nature of an offence was a question of politics and diplomacy, and as such, it was an executive decision. ${ }^{304}$

The opponents of the new provision were concerned with its political and human rights implications. The extraditability of the accused between the US and the UK now depended on the current definition of 'political offence' adopted by the executive. This made the decision-making more volatile and potentially arbitrary, potentially leading to human rights violations. ${ }^{305}$ Some feared that the executive could be affected by pressure from terrorists. ${ }^{306}$

297 Blakesley, 1986, 120-122.

298 However, sometimes this was questioned by fugitives. Pyle, 2001, 96-104.

299 See on the relationship between the executive and the judiciary in US extradition before the Supplementary Treaty e.g. Epps, 1979, 74.

300 Article 4, Colombia International Extradition Treaty with the United States, 14 September 1979.

301 Article 4, Extradition Treaty between the Kingdom of the Netherlands and the United States of America, 24 June 1980.

302 This argument was made by e.g. the US Department of State Legal Advisor Abraham Sofaer. See Blakesley, 1986, 118-119.

303 Pyle, 1988, 189; Pyle, 2001, 202.

304 This was the opinion of e.g. Special US Attorney Thomas H. Belote. See Pyle, 2001, 172. See also the comment by Gilbert, 1998, 330 .

305 Carbonneau, 1983, 234-235; Blakesley, 1986, 119; Groarke, 1988, 1529; Gilbert, 1991, 163-164; Gilbert, 1998, 332.

306 Freestone, 1981, 207. 
The new treaty was also criticised for being against the principle of the separation of powers, as the application of the extradition treaties was traditionally understood as a legal decision. ${ }^{307}$ For instance, the US Congress criticised the treaty for this reason. ${ }^{308}$ Early lawmakers in the US had seen extradition as a judicial rather than political matter. ${ }^{309}$ This principle had been already confirmed in the 1842 Webster-Ashburton treaty between the US and Great Britain (UK). ${ }^{310}$

According to Blakesley, the new treaty gave the constitutional role of courts to the executive for political reasons. Further, it deemed the courts incompetent due to the dissatisfaction of the executive and the British government with the outcomes of some of the court cases. Blakesley expressed his concern for the possible erosion of the foundation of the extradition process, laid on the principle of rule of law. ${ }^{311}$

Many writers have argued that the treaty essentially eliminated the POE. ${ }^{312}$ Some maintained that the treaty violated the equal protection clause of the Fifth Amendment by offering protection to some political offenders (those requested by states other than the United Kingdom), while denying it to others (those requested by the United Kingdom). ${ }^{313}$ Additionally, the retroactivity of the Supplementary Treaty was considered unconstitutional. ${ }^{314}$

The categorical exclusion of violent crimes in the US-UK Supplementary Treaty, and also in the ECST, has been criticised for protecting those in power, no matter how bad the system. ${ }^{315}$ John Patrick Groarke has pointed out that even many of the respected 'Founding Fathers' of the United States had employed violent tactics in their struggle against the British colonial rule. Should the Supplementary Treaty have been applied to their actions, they as well would have been delegitimised. However, since the revolutionary period, both the UK and the US had developed into democracies within which it was hard to imagine the need for political violence. Groarke continued: "It is by no means certain, however, that such circumstances will not occur sometime in the future." 316

A number of contemporaries criticising the Supplementary Treaty considered the Northern Irish judicial system an imbalanced forum for a trial of an accused terrorist. ${ }^{317}$ In the so-called Diplock courts, set to deal with violent crime and

307 Blakesley, 1986, 120.

308 Friedlander, 1988, 19-20.

309 Nadelmann, 1993, 846; Pyle, 2001, 67.

310 Pyle, 2001, 70.

311 Blakesley, 1986, 120-124.

312 Blakesley, 1986; Petersen, 1992, 767, 779; DeFabo, 2012, 87.

313 Basso, 1989, 315.

314 Political criminals, whose extradition had already been denied, would possibly be extradited once the treaty came into force, should the United Kingdom make a new request. Basso, $1989,316$.

315 Pyle, 1988, 200.

316 Groarke, 1988, 1528.

317 Groarke, 1988, 1532; Hoffman, 1989; Petersen, 1992, 786. However, for instance Kulman has called the British judicial system "fundamentally fair" and argued that anyone accused of crimes excluded from the scope of the POE in the Supplementary Treaty would receive a fair trial. Kulman, 1986, 779. 
specifically terrorism, no jury trial was used. According to the European Court of Human Rights, this could amount to degrading or inhumane treatment. ${ }^{318}$ This was also of concern in the US Congress, which additionally expressed its concern about the status of so-called freedom fighters. ${ }^{319}$

The proponents of the Supplementary Treaty argued that judicial collaboration with a country with a democratic system of government and a fair judiciary did not require retaining the POE for violent offenders. ${ }^{320}$ The critics, in turn, worried that offering diverse treatment to different countries could lead to similar limitations with less democratic allies ${ }^{321}$ and would be a potential source of diplomatic problems. ${ }^{322}$ President Reagan argued that the treaty would not set a precedent to others that could be used against people fighting their oppressors. ${ }^{323}$

Regardless of Reagan's claims, the United States did later try to negotiate similar treaties with a number of other countries. Since 1986, the Supplementary Treaty was used as a model for treaties with allied democracies. West Germany and Canada agreed, Australia refused, and the Belgium treaty never went into force. ${ }^{324}$ According to Christopher H. Pyle: "By these agreements, the US government decided, in effect that it could not imagine a circumstance under which it would ever be legitimate to assert a right of revolution against these favoured governments. George Washington would never have been so naive." 325

The Supplementary Treaty represented, in fact, just a part of the new extradition treaty policy that had begun in the early years of the 1980s. The new policy had already been visible in 1981 in the Reagan administration's attempt to negotiate an extradition treaty with the Philippines. The US offered assistance to the former dictator, Ferdinand Marcos, in the extradition of his opponents dwelling in the US. The proposed treaty with a country president Reagan called 'democratic' resulted in a public outcry and the treaty was never taken into the Senate for final approval. ${ }^{326}$ The State Department worried that the treaty could jeopardise the attempt to eliminate the POE and for this reason, it was not put forward. ${ }^{327}$ Similar treaties that were equally problematic were planned with South Korea, South Africa and El Salvador. These states were of strategic importance to the US,

318 Petersen, 1992, 786. See in more detail on the courts e.g. Bonner, 1988.

319 Friedlander, 1988, 19-20.

320 Kulman, 1986, 776; Sofaer, 1986, 132.

321 Basso, 1989, 315; Groarke, 1988, 1541.

322 Groarke, 1988, 1540; Hannay, 1988, 122. Interestingly, the same criteria had been applied when evaluating whether a person deserved protection as a refugee. Those fleeing "friendly nations" could not receive protection. McElrath, 2000, 28.

323 Reagan, 1986.

324 The Supplementary Treaty to the Treaty between the United States of America and the Federal Republic of Germany Concerning Extradition, 21 October 1986; Protocol amending the 1971 Extradition Treaty between the United States of America and Canada, 11 November 1988; Treaty on Extradition between Australia and the United States of America, 4 September 1990.

325 Pyle, 2001, 204.

326 Groarke, 1988, 1542; Pyle, 2001, 198.

327 Pyle, 2001, 199. 
but also were criticised for their lack of democracy and foul treatment of political enemies. ${ }^{328}$

Regardless of the criticism, the Supplementary Treaty was thus not the only one of its type, and it did draw on the ECST, which had previously received lots of support. The ECST similarly restricted the POE, but as it was drawn up in a different context, it was received differently. ${ }^{329}$ Additionally, for instance, Canada later negotiated treaties with similar restrictions, ${ }^{330}$ however not systematically. ${ }^{331}$ In 1987, the South Asian Association for Regional Cooperation (SAARC) Regional Convention on the Suppression of Terrorism openly condemned terrorism and depoliticised crimes covered by UN treaties such as the Hague and the Montreal Conventions. The convention also excluded from the protection of the POE a long list of violent offences such as murder, hostage-taking and crimes relating to weapons, "when used as a means to perpetrate indiscriminate violence involving death or serious bodily injury to persons or serious damage to property." Such a provision is relatively novel and atypical for the period, especially because it included the provision relating to property. This convention not only depoliticised the treatment of terrorist crimes but also the crimes themselves. The definition offered does not make any reference to motivations but separates terrorist acts from other types of violent crimes by their indiscriminate nature. ${ }^{332}$

Pyle concluded in reaction to the 1986 Supplementary Treaty:

In the late twentieth century, Locke and Hobbes appear to be giving way to a combination of Max Weber and right-wing anti-Communism. The result is a powerful assault on the idea that the political offence exception to extradition should be administered in an evenhanded fashion to political fugitives of all stripes. This assault is not just on the idea of a neutral refusal to extradite fugitives from both sides of foreign uprisings. It is an assault upon the independence and impartiality of courts. The US-UK treaty, for example, actually strips the courts of both nations of their 140-year-old authority to block the extradition of revolutionaries against the other regime. The power to grant political asylum and to refuse to surrender persons declared extraditable by the courts will be retained by the executive of both nations, to be exercised according to political, rather than strictly legal criteria. Neither the Reagan nor Thatcher administrations opposes shielding from extradition fugitives that they do not favour. They simply want to prevent courts from shielding fugitives that they do not favour. Like most emergency law, the US-UK treaty represents a very short-term view of law. ${ }^{333}$

328 Blakesley, 1986, 122.

329 Petersen, 1992, 784-786.

330 Article 3, Treaty of Extradition Between Canada and Spain, 31 May 1989.

331 See e.g. Extradition Treaty between the Government of Canada and the Government of the Republic of France, 17 November 1988, which does not contain limitations to the POE.

332 Article 1, South Asian Association for Regional Cooperation (SAARC) Regional Convention on the Suppression of Terrorism, 4 November 1987. Italics added.

333 Pyle, 1988, 182. 
Interestingly, regardless of the problems the political nature of terrorism had caused the UK in its intranational relations, in its 1989 law, it still defined terrorism as "the use of violence for political ends, and includes any use of violence for the purpose of putting the public or any section of the public in fear." ${ }^{334}$ It is also noteworthy that even with the new treaty, the policy change was not completely straightforward. As a follow-up to the second IRA ceasefire in 1997, the US dropped the deportations of several members of the IRA, and, according to McElrath, the government recognised, although not openly, the political nature of the offences of (former) IRA members by declaring its support for the political peace process. Simultaneously, it was underlined that the dropping of the deportation did not mean that the US would approve of previous terrorist activity. McElrath, who has been very critical of the overall deportation policies of the US, has interpreted this policy change as a negation of the British criminalisation policy. However, not all Irish deportations were dropped. ${ }^{335}$

\subsection{Conclusion}

This chapter has shown that the changes in the nature of terrorism since the $1970 \mathrm{~s}$ affected global antiterrorist conventions and policies. Also, the way in which the notion of terrorism was understood underwent changes during this period. In the 1970s and 1980s, terrorism was typically considered a political threat and the grievances of terrorists were discussed, alongside measures of collaboration in fighting against it. However, this view gradually changed as terrorism became a more acute threat for Western states.

With the rise in the threat of terrorism, the POE started to change. Many of the UN reforms were stalled or watered by those states that wanted to keep protecting revolutionaries. Interpol was even more incapable of acting against the terrorist threat as it was limited by its constitution, but it started to change its position in the early years of the 1980s.

The United Nations chose a 'patchwork' approach, where it created treaties on specific types of violent conduct that states were to criminalise. The incorporated aut dedere aut judicare principle was intended to abolish criminal safe havens. Terrorism was still mainly considered a political problem, but slowly the organisations started to take a clearer stance against violent means in promoting political change. The most important changes, however, only took place in the coming decades. Progressively, UN treaties and resolutions started to affect national laws and bilateral extradition treaties.

In the 1970s and 1980s, Europe encountered an unforeseen wave of terrorism which left its mark on the political offence exception. Terrorist movements in

334 Prevention of Terrorism (Temporary Provisions) Act 1989 c. 4, Part V, 20. Similarly, in its Terrorism Act 2000, the definition of terrorism included the concept of an ideological purpose: "(c) the use or threat [of terrorism] is made for the purpose of advancing a political, religious or ideological cause.” Part I, 1(c), Terrorism Act 2000 (c.11).

335 McElrath, 2000, 41-42. Italics orig. 
Germany and Italy evoked a European response in the form the 1977 European Convention on the Suppression of Terrorism, which depoliticised terrorist acts for the purposes of extradition, however leaving room for reservations.

During the 'Troubles,' a period of an open battle between the IRA and the British regime, IRA members were able to find refuge in the US, creating diplomatic problems and later leading to the supplementary extradition treaty between the US and the UK in 1985. The 1985 treaty was the first bilateral extradition treaty to have made serious restrictions to the POE. Its creation was a result of converging political interests between the Reagan and Thatcher regimes. Ronald Reagan was president of the United States from 1981 to 1989 and Margaret Thatcher was prime minister of the United Kingdom from 1979 to 1990. The two conservative regimes were dedicated to the fight against terrorism and thus formed a logical alliance. Collaborating in the matter of IRA fugitives was a necessity for a credible and functioning partnership in the matter of transnational terrorism. The Supplementary Treaty depoliticised terrorist acts and removed the tension between the countries, which had resulted from the repeated non-extraditions from the US to the UK of claimed IRA terrorists.

The debates of this era clearly present the problematic and political nature of extradition procedures. Even if in the early days it was seen that the POE protected states from meddling in the internal affairs of another state, the USUK diplomatic problems demonstrate that protecting political offenders is by no means less political than not sheltering them. Even if the POE was an 'automatic' system applied to all cases by the courts, it was affected by political concerns and it provoked political reactions. For this reason, it was put under closer scrutiny, until it eventually suffocated to death within Europe. 


\section{Dedication to the fight against terrorism since the 1990s}

\subsection{Changes in global views on terrorism}

\subsubsection{A new understanding of terrorism in the United States}

In the 1990s, terrorism underwent important changes in the 1990s and became recognised as a global threat. The number of casualties in terrorist attacks rose together with a change in motivations and nature of the attacks. Simultaneously, the collapse of the Soviet Union altered the balance of power in the world. At a very fast pace, the world transformed from a bipolar system to a system where the United States represented the sole great power. As a consequence, the biggest threat to the security of the United States, the possibility of a nuclear war with the Soviet Union, had also vanished. For this reason, the focus of the United States was increasingly on fighting terrorists.

From the 1960s until the 1990s, most major terrorist organisations were ideological, ethno-nationalistic or separatist ${ }^{1}$ with tactical and instrumental aims. Since the 1990s, terrorism has more commonly been motivated by religion. In 1995, half of the identifiable international terrorist groups were religiously motivated. The transformation of Iran into an Islamic republic in 1979 had a role in the rise of religiously motivated terrorism, but cannot be seen as the unique reason for it. Even if religious terrorism has especially been associated with the Islamic world, the use of terroristic means has not been limited to Islam. ${ }^{2}$

The rise of religion as a motivation for terrorist acts seems to reflect the failure of old ideologies: the Soviet Union had collapsed but capitalism was not benefitting all. Societal changes such as accelerated population growth and urbanisation, combined with the breakdown of local services, increased a sense of public insecurity. ${ }^{3}$ The turn towards religion for a vision of a better world was partly a result of the failure of secular ideologies in their promises of modernisation.

1 Hoffman, 1998, 200.

2 It must be noted that religion as a motivation for acts that would be labelled terrorism in modern days was not a novel phenomenon, but it had existed for thousands of years. Hoffman, 1998, 87-91.

3 Hoffman, 1998, 92. 
In addition, the emergence of religious terrorism has also been associated with the emigration of radicalised Mujahedin from Afghanistan. ${ }^{4}$ However, nationalist and revolutionary terrorism did not extinguish with the surfacing of religiously motivated terrorism on the public agenda. ${ }^{5}$

Religious motives changed the nature of terrorism. In religious terrorism, the basis of the use of violence is not constrained by political, moral or practical concerns since it is legitimised by a belief in a higher power. Political terrorists rarely aim at the largest amount of victims possible, whereas religious terrorists typically see their victims as enemies to their beliefs. Secular terrorism seeks approval also from outsiders, whereas religious terrorism does not need it. As a result, all others, except for the members of the community, are labelled as enemies, for example, 'infidels.' Additionally, political terrorists typically want to correct or replace the existing system, but religiously motivated terrorists see themselves as outsiders and thus are not committed to the developing of the existing order. ${ }^{6}$ As religious terrorists are unpredictable and difficult to identify, traditional counterterrorist measures employed against secular terrorists are not useful when confronting them. ${ }^{7}$

The notion of the major differences between religiously motivated and politically motivated terrorism has, however, been contested. Colin Wight has argued that "contemporary Islamic terrorism is political through and through, and, indeed, rests on a fundamentally different conception of sovereignty." 8

The aforementioned changes had an effect on the US, which emerged as one of the key targets of terrorists. Several terrorist incidents, many of which targeted the US, received worldwide publicity, including the World Trade Center bombing on February 26, 1993, and the bombing of the US embassies in Kenya and Tanzania in 1998. In the embassy bombings, two car bombs planted by Al Qaeda exploded simultaneously and killed more than 200 people. Al Qaeda also bombed the warship USS Cole in 2000, killing 17 sailors and wounding 35 . The bombing in Oklahoma City, Oklahoma, conducted by Timothy McVeigh and Terry Nichols as a reaction to perceived misconduct by the state, targeted US citizens on its own soil. Additionally, the 1995 nerve gas attack by members of the cult movement Aum Shinrikyo in the Tokyo subway system was initially planned to be carried out in the US. ${ }^{9}$

4 Aldrich, 2004, 750; Patterson, 2005, 196.

5 Wight, 2015, 195.

6 Hoffman, 1998, 94-95.

7 Hoffman, 1998, 128.

8 Wight, 2015, 113. Further, "Whilst it has often been thought that contemporary terrorism is irrational, nihilistic and essentially evil, contemporary Islamic terrorists do have very specific aims. These are: 1) to pull states within the system into unnecessary and costly conflicts (Iraq, Afghanistan, possibly Iran); 2) one of the spin-offs from these costly wars, the terrorists hope, will be pressure on the international financial system; and 3 ) that in attempting to secure their populations from attack and safeguard the system as a whole the values the system purports to uphold will be overturned and ignored in the search for security." Wight, 2015, 201.

9 Hoffman, 1998, 93, 199; Aldrich, 2004, 750; Patterson, 2005, 380-381. 
US antiterrorism policies were also affected by other major political changes such as the dismantling of the Soviet Union, which meant the disappearance of the biggest and most obvious political adversary, as well as of the election of a liberal Democratic administration in 1993. These alterations created a completely new political situation.

One of the most noteworthy novelties in the Clinton administration policies was that the Democratic Party made an attempt to separate the notion of terrorism from the Middle Eastern context. Instead, it aimed at focusing more on domestic rather than international terrorism. ${ }^{10}$ This could have been affected by the role of the US as an intermediary in the Middle East peace process, ${ }^{11}$ but such a claim would require further study. However, the Clinton administration was also fighting terrorism on all fronts. According to one estimate, spending on counterterrorism, including military means used to fight terrorists, actually rose by 50 per cent between 1998 and $2001 .^{12}$

The means to fight terrorism, however, changed. The liberal approach was to combat terrorism using legal and constitutional measures to underline the value of human rights. ${ }^{13}$ Extradition is a legal tool, which acknowledges the human rights of the fugitive, and as such was a fitting method for the fight against terrorism for the purposes of the Clinton administration. In this context, it is understandable that extradition treaties were slowly being modified to work better against the terrorist threat.

The political offence exception (POE) had already earlier proved a stumbling block for the purposes of the fight against terrorism, especially because of the liberal administration's focus on the legal, rather than military, fight against the threat. Even if problematic, the political offence exception persisted in US treaties under the Clinton administration. The 'multilateral treaty clause' and the attentat clause were commonly used, but other limitations remained rare. The multilateral treaty clause meant that offences regarding which one of the treaty parties had an international duty to either prosecute or extradite would "not to be considered [a] political offence $[\mathrm{s}]^{\prime \prime 14}$

10 Jenkins, 2003, 43-44, 49.

11 See e.g. Patterson, 2005, 335-336; and BBC News, "History of Mid-East peace talks," 29 July 2013, http://www.bbc.com/news/world-middle-east-11103745.

12 Patterson, 2005, 381-383.

13 Jenkins, 2003, 47.

14 See e.g. Article 3, Extradition Treaty between the Government of the Republic of the Philippines and the Government of the United States of America, 13 November 1994. Article 4, Extradition Treaty between the Government of the United States of America and the Government of Malaysia, 3 August 1995. Article 4, Extradition Treaty between the Government of the United States of America and the Government of the Republic of Trinidad and Tobago, 4 March 1996. Another wording was in the USA-Bolivia treaty: "offences as to which there is an obligation to establish criminal jurisdiction pursuant to multilateral international treaties in force with respect to the Parties." Article 5, Treaty between the Government of the United States of America and the Government of the Republic of Bolivia on Extradition, 27 June 1995. Article 4, Extradition Treaty between the Government of the 
Almost all US extradition treaties since the beginning of the 1990s contained the Belgian clause, ${ }^{15}$ with the exception of the US-Swiss treaty of $1990 .{ }^{16}$ In addition, many treaties, such as the 1994 US-Philippines and the 1995 US-Bolivia treaties, provided that conspiracies to commit the excluded crimes, or aiding or abetting the commission of these crimes, would not be protected by the POE. However, protection to the fugitive was facilitated by providing for the denial of extradition, should the executive authority of the requested state consider the request as politically motivated. ${ }^{17}$

A typical US extradition treaty of the 1990s still made no reference to terrorism. The first treaty since the one signed in 1978 with West Germany to use the concept of terrorism was the 1995 treaty with Jordan. The letter of submittal, signed by US President Bill Clinton, stated that "The Treaty further represents an important step in combatting terrorism by excluding from the scope of the political offence exception serious offences typically committed by terrorists, e.g., crimes against a Head of State or first family member of either Party, aircraft hijacking, aircraft sabotage, crimes against internationally protected persons, including diplomats, hostage-taking, narcotics trafficking, and other offences for which the United States and Jordan have an obligation to extradite or submit to prosecution by reason of a multilateral international agreement or treaty." The treaty text itself was not, however, in any way atypical and did not contain any

United States of America and the Government of Grenada, signed at St George's, 30 May 1996. For instance, the treaty with Sri Lanka lists some of these treaties by title, but contains the "multilateral treaty" exclusion similar to the mentioned one. Article 4, Extradition Treaty between the Government of the United States of America and the Government of the Democratic Socialist Republic of Sri Lanka, 30 September 1999. Article 3, Extradition Treaty between the Government of the United States of America and the Government of the Swiss Confederation, 14 November 1990.

15 See e.g. Article 3, Extradition Treaty between the Government of the Republic of the Philippines and the Government of the United States of America, 13 November 1994. Poland International Extradition Treaty with the United States, 10 July 1996. Extradition Treaty between the Government of the United States of America and the Government of Grenada, signed at St George's, 30 May 1996. Article 4, Extradition Treaty between the United States of America and the Grand Duchy of Luxembourg, 1 October 1996. Article 4, Extradition Treaty between the Argentina Republic and the United States of America, 10 July 1997.

16 Article 3, Extradition Treaty between the Government of the United States of America and the Government of the Swiss Confederation, 14 November1990.

17 See e.g. Article 3, Extradition Treaty between the Government of the Republic of the Philippines and the Government of the United States of America, 13 November 1994. Article 5, Treaty between the Government of the United States of America and the Government of the Republic of Bolivia on Extradition, 27 June 1995. Article 4, Extradition Treaty between the Government of the United States of America and the Government of the Republic of Trinidad and Tobago, 4 March 1996. Article 4, Extradition Treaty between the Government of the United States of America and the Government of Grenada, signed at St George's, 30 May 1996.The USA-Malaysia treaty also excluded "an attempt or conspiracy, or aiding or abetting, counselling or procuring the commission of or being an accessory before or after the fact to, such offences." Article 4, Extradition Treaty between the Government of the United States of America and the Government of Malaysia, 3 August 1995. 
novelties. The terrorism reference of the letter of submittal covered only violent crimes that had been excluded from the protection of the POE already in previous treaties. ${ }^{18}$ After the Jordan treaty, similar provisions were used in the treaty texts of the 1997 treaty with Argentina ${ }^{19}$ and the 1998 treaty with South Korea ${ }^{20}$ as well as the 2001 treaty with Peru. ${ }^{21}$

The concept of terrorism was not commonly used in non-US extradition treaties. However, at least international treaties excluded terrorist acts from the POE. For instance, the Mercosur, Bolivia and Chile treaty of 1998 excluded from the scope of the POE attacks on the lives of heads of states, international crimes, as well as terrorist acts, consisting of crimes covered by United Nations (UN) Conventions, such as hostage-taking, attacks against diplomats, bombings and other crimes. ${ }^{22}$ Also, the Brazil-Spain treaty from 1988 and the Brazil-Canada treaty from 1995, for instance, have excluded terrorist crimes from the scope of the POE. ${ }^{23}$

In 1996, the US agreed upon a new extradition treaty with France to replace a treaty dating from 1909. ${ }^{24}$ The 1996 treaty, as one of the few US treaties of the period, specifically mentioned terrorism as one of the reasons why the treaty was created in the letter of submittal: "The treaty represents part of a concerted effort by the Department of State and the Department of Justice to develop modern extradition relationships to enhance the United States ability to prosecute serious offenders including, especially, narcotics traffickers and terrorists." ${ }^{25}$

In addition to the specific mention of terrorism, the 1996 treaty is of special interest due to its provisions with regard to the POE. The previous treaty had contained a traditional political offence clause: "A fugitive criminal shall not be surrendered if the offence in respect of which his surrender is demanded to be of a political character, or if he proves that the requisition for his surrender has, in fact, been made with a view to try or punish him for an offence of a political character." 26 The POE in the new US-France treaty atypically differentiated

18 Jordan International Extradition Treaty with the United States, 28 March 1995.

19 Article 4, Extradition Treaty between the Argentina Republic and the United States of America, 10.7.1997.

20 Article 4, Extradition Treaty between the Government of the Republic of Korea and the Government of the United States of America, 9 June 1998.

21 Extradition Treaty between the Government of the United States of America and the Government of the Republic of Peru, 26 July 2001.

22 Article 5, Acuerdo sobre extradición entre el Mercosur, la República de Bolivia y la Republica de Chile, 10 December 1998.

23 Article 3, Tratado de extradição entre o Governo da República Federativa do Brasil e o Governo do Canada, 27 January 1995; Article 4, Tratado de extradição entre a República do Brasil e o Reino da Espanha, 2 February 1988.

24 Convention d'extradition entre la France et les Etats-Unis d'Amérique, 6 January 1909.

25 The same provision was also added to the US-Poland treaty of 1996. Letter of submittal, Poland International Extradition Treaty with the United States, 10 July 1996.

26 Article 6, Convention d'extradition entre la France et les Etats-Unis d'Amérique, 6 January 1909. 
between the ways in which the two states interpreted the exemption: "Extradition shall not be granted by France when the offence for which extradition is requested is considered by France as a political offence or as an offence connected with a political offence or as an offence inspired by political motives. Extradition shall not be granted by the United States when the offence for which extradition is requested is considered by the United States to be a political offence." ${ }^{27}$ Thus the French took a much wider stance towards which crimes could be considered political offences. This is in sharp contrast with France's historically narrow take on the concept of political offence. ${ }^{28}$

The US-France treaty of 1996 also included the attentat clause, the multilateral treaty clause, and several other exclusions from the scope of the POE, such as "a serious offence involving an attack against the life, physical integrity or liberty of internationally protected persons, including diplomatic agents," kidnapping, the taking of hostages, or "an offence involving the use of a bomb, grenade, rocket, automatic firearm or letter or parcel bomb if this use endangers persons" as well as attempts or conspiracies to commit any of these crimes..$^{29}$

Additionally, the US-France treaty contained a specific provision providing that the requested state could still refuse to extradite crimes excluded from the political offence exception, but "In evaluating the character of the offence, the Requested State shall take into consideration the particularly serious nature of the offence, including: (a) that it created a collective danger to the life, physical integrity or liberty of persons; (b) that it affected persons foreign to the motives behind it; or (c) that cruel or treacherous means have been used in the commission of the offence." 30

Thus the treaty text seems to include a reference to the Swiss predominance test. The formulation of the treaty text is curious, as the same goal of introducing the predominance test to the treaty would have sufficed without listing the limitations to the POE. A simpler version of the text would have excluded political offences, with a limitation to cases where they created collective danger, affected innocents or used cruel means.

The US-France treaty used the depoliticisation formula, "the following offences shall not be considered to be political offences," but it was limited to the purposes of the treaty in question. ${ }^{31}$ In other words, the offences were not

27 Article 4, Extradition Treaty between France and the United States of America, 23 April 1996.

28 See Chapter 2, Section 2.2.5.

29 Article 4, Extradition Treaty between France and the United States of America, 23 April 1996. The 1996 treaty with Luxembourg contained almost identical provisions. Article 4, Extradition Treaty between the United States of America and the Grand Duchy of Luxembourg, 1 October 1996.

30 Article 4(3) and 4(4), Extradition Treaty between France and the United States of America, 23 April 1996.

31 Article 4, Extradition Treaty between France and the United States of America, 23 April 1996. 
claimed to be non-political, but they would be treated as such in applying the treaty. The same phrasing was used in the US-Poland treaty. ${ }^{32}$ The French treaty also used the discrimination clause, ${ }^{33}$ which was otherwise used only seldom in US extradition treaties: in the 1983 treaty with Jamaica, ${ }^{34}$ in the 1998 treaty with South Korea, ${ }^{35}$ the 1999 treaty with South Africa ${ }^{36}$ and the 2005 treaty with Israel. ${ }^{37}$

As the scope of the POE was evidently progressively narrowed in US extradition treaties during the 1990s, the courts had fewer opportunities to interpret terrorist deeds as political offences. Court practice started to slowly change. Previously, courts had heavily leaned on the incidence test, meaning that all crimes committed during a political uprising or unrest had automatically been covered by the POE. Now they started to apply the test in a more restricting manner.

One of the most noteworthy cases where the new take on the incidence test was visible was that of Singh in 2001. Singh was wanted for several murder, attempted murder and robbery charges. The crimes had taken place in the early 1990s when Sikh militants sought to establish Khalistan as a sovereign nation separate from India. ${ }^{38}$

The US-India extradition treaty of 1997, on which the extradition was sought, contained the political offence exception. The exemption was limited by the attentat clause as well as by the multilateral treaty clause. Additionally, according to its provisions, the POE could not be applied to conspiring to commit any of such offences, or aiding or abetting their commission. ${ }^{39}$

32 Article 5, Poland International Extradition Treaty with the United States, 10 July 1996.

33 "L'extradition n'est pas accordée si les autorités compétents pour la France ou si le Pouvoir exécutif des Etats-Unis ont des raisons sérieuses de croire que la requête a pour but de poursuivre ou de punir une personne pour des considérations de race, de religion, de nationalité ou d'opinions politiques." Article 4(2), Extradition Treaty between France and the United States of America, 23 April 1996.

34 Jamaica International Extradition Treaty with the United States, 14 June 1983.

35 Extradition Treaty between the Government of the Republic of Korea and the Government of the United States of America, 9 June 1998.

36 Extradition Treaty between the Government of the United States of America and the Government of the Republic of South Africa (with annex), 16 September 1999.

37 Protocol between the Government of the State of Israel and Government of the United States amending the Convention on extradition signed at Washington D.C. on December 10, 1962, 6 July 2005.

38 In re Extradition of Singh, 170 F. Supp. 2d 982 (E.D. Cal. 2001). See in more detail Rogers, 2003.

39 Article 4, Extradition Treaty between the United States of America and India, 25 June 1997: Article 4: Political offences: 1. Extradition shall not be granted if the offence for which extradition is requested is a political offence. 2. For the purposes of this Treaty, the following offences shall not be considered to be political offences: (a) a murder or other willful crime against the person of a Head of State or Head of Government of one of the Contracting States, or of a member of the Head of State's or Head of Government's family; (b) aircraft hijacking offences, as described in The Hague Convention for the Suppres- 
India argued that attacks against police officers should be considered as attacks against civilians. According to the court, however, Indian police forces were paramilitary in nature and attacks against them thus were political or military in nature. Both types of offences were exempted from extradition according to the US-India extradition treaty.

In August 2001, the District Court made a thorough investigation of the political conditions in India. The court acknowledged the political nature of the Sikh movement. It pointed out that the new antiterrorist law in India sought to punish terrorism and "disruptive acts" that included "speech or actions that disrupt or challenge the sovereignty or territorial integrity of India." Additionally, the crimes occurred during "the highest period of militancy and armed conflict with casualties on all sides." However, the court also underlined, in reference to the Ahmad decision, that "Political motivation does not turn every crime into a political offence." Thus, according to the court, regardless of the political uprising that existed in India at the time of the crimes, some of the crimes Singh was wanted for were not incidental to the political uprising and therefore they were extraditable. These crimes consisted of attacks against civilians committed separately from the uprising. ${ }^{40}$ Rogers has pointed out that this case demonstrated "the ongoing ambiguity enveloping the political offence exception." 41

\subsubsection{Interpol adopts a new take on terrorism since the $1980 \mathrm{~s}$}

Even if dedication to the fight against terrorism started to grow in the 1980s, the 1990s can be viewed as a global turning point in the way in which terrorism was viewed and treated globally. For the UN and Interpol, the major transition with regard to terrorism took place in the mid-1990s.

sion of Unlawful Seizure of Aircraft, done at the Hague on December 16, 1970; (c) acts of aviation sabotage, as described in the Montreal Convention for the Suppression of Unlawful Acts Against the Safety of Civil Aviation, done at Montreal on September 23, 1971; (d) crimes against internationally protected persons, including diplomats, as described in the Convention on the Prevention and Punishment of Crimes Against Internationally Protected Persons, including Diplomatic Agents, done at New York on December 14, 1973; (e) hostage taking, as described in the International Convention against the Taking of Hostages, done at New York on December 17, 1979; (f) offences related to illegal drugs, as described in the Single Convention on Narcotic Drugs, 1961, done at New York on March 30, 1961, the Protocol Amending the Single Convention on Narcotic Drugs, 1961, done at Geneva on March 25, 1972 and the United Nations Convention against Illicit Traffic in Narcotics Drugs and Psychotropic Substances, done at Vienna on December 20, 1988; (g) any other offence for which both Contracting States have the obligation pursuant to a multilateral international agreement to extradite the person sought or to submit the case to their competent authorities for decision as to prosecution; and (h) a conspiracy or attempt to commit any of the foregoing offences, or aiding or abetting a person who commits or attempts to commit such offences.

40 Country Reports on Human Rights Practices for 1991, U.S. Dept. of State, 1031 1394. See In re Extradition of Singh, 170 F. Supp. 2d 982 (E.D. Cal. 2001).

41 Rogers, 2003, 486. 
The influence of the interests of the United States on both organisations can only be speculated within the confines of this study, but perhaps due to US administrations liberal values, the eyes of the US turned towards the use of international organisations in countering terrorism. According to David Held, the UN was susceptible to the agendas of the most powerful states, especially due to its financial dependence on its member states. ${ }^{42}$ Similarly, the role of member states in affecting the agenda of Interpol cannot be underestimated.

The turnaround in the policies was especially clear with regard to Interpol, which had been unable to react to terrorism during previous decades. Interpol's new stance against terrorism was gradually formed between the years 1982 and 1985. Terrorism became an open concern of the organisation and the limitations provided by its constitution were steadily overruled by a new policy which put the fight against terrorism in a central position for the organisation during the 1990s.

Many Third World nations had wished Interpol to act in a more determined way against terrorism and to change its interpretation of the binding Article 3 of the constitution ${ }^{43}$ that forbade Interpol to undertake matters of a political, military, religious or racial character, and the necessity of distancing the organisation from political matters. The Executive Committee of Interpol did not want the organisation to take up this task. Developed nations were also reluctant. Unexpectedly, the United States changed its attitude dating from the 1950s and stated that Interpol had an obligation to address terrorism. ${ }^{44}$ While Western European countries interpreted the causes of terrorism to be wider problems in the international system, the United States began to view some specific countries as the sources of terrorism. ${ }^{45}$

The resolution from 1983 titled Terrorism was the first Interpol resolution to make open reference to the phenomenon but it still emphasised the importance of Article 3. The following year, the resolution Violent Crime Commonly Referred to as Terrorism made it possible for the organisation to engage in, under certain circumstances, cases related to terrorism. According to Interpol's own website: "This position, adopted despite the fact that terrorism remains inherently political, is aligned with developments in international extradition practice: Terrorism is no longer considered a political offence for purposes of extradition, thereby falling outside the political offence exception in international extradition law."46

It is interesting that the organisation noted the change in extradition practices already at a very early stage when states like the US were still balancing between protecting some violent offenders and extraditing others. The fight against terrorism by means of extradition was not yet a confirmed practice. The statement was

42 Held, 1995, 88.

43 Interpol Constitution I/CONS/GA/1956, 13 June 1956.

44 Fooner, 1989, 43.

45 Aldrich, 2004, 750 .

46 Interpol resolution AGN/53/RES/7, Application of Article 3 of the constitution, Luxembourg, 1984. 
most likely made to reference UN antiterrorism conventions and the European Convention on the Suppression of Terrorism (ECST), which had limited the application of the POE to terrorism-related offences.

With this change of policy, it became possible for Interpol to collaborate in cases that related to political terrorism outside conflict areas, which essentially meant that the organisation could be used as a means to coordinate efforts in capturing Irish Republican Army (IRA) members accused of terrorist acts that took place on mainland Europe. The limitation still persisted with regard to those acts committed domestically on the territory of the UK. The role of Interpol was that of an important active point of collaboration because it provided a formalised forum for low-level contacts between police officers. ${ }^{47}$

The change in the antiterrorist policy of Interpol reflected, at least in part, the growth of the US influence on the organisation. According to Anderson, the reinterpretation of Article 3 was the result of "a combination of American pressure, sensitivity to sections of western public opinion alarmed by terrorism, and fear that the Organisation could be marginalised." 48 According to Fooner, a turn in the organisation's leadership had taken place in 1984 as a result of American pressure ${ }^{49}$ By 1985 a new policy toward terrorism was widely accepted and member countries could deal with it from a law-enforcement perspective. ${ }^{50}$

Interpol had been under different dominations since its creation. When it was established, it was mostly a Central European organisation. During the Second World War, it was taken over by Nazis. As the headquarters was moved to France after the war in 1946, French domination over the organisation began. ${ }^{51}$ Only in the 1980s, new leading members emerged: the US, West Germany, Britain, Canada and Japan. ${ }^{52}$ This raises the question of the control of the organisation in the 2000s. As Andreas and Nadelmann have claimed, "international crime control is one of the most important - and one of the most overlooked - dimensions of US hegemony in world politics. ${ }^{53}$ For this reason, the question of dominance is very important.

The devastating attacks against the US embassies in Eastern Africa in 1998 provoked reactions from both the UN and Interpol. Interpol confirmed its commitment to combatting international terrorism by depoliticising terrorist acts in 1998, which was the same year that witnessed a turnaround in the UN policies. A formal set of New Guidelines for Co-operation in Combating International Terrorism ${ }^{54}$ more explicitly addressed the relationship of terrorism to the previously problematic Article 3 of the constitution. Basically, with the help of the

47 Gilbert, 1991, 34. See also Gilbert, 1998, 61-62.

48 Quoted in Deflem, 2005.

49 Fooner, 1989, 164.

50 Fooner, 1989, 43.

51 Fooner, 1989, 91.

52 Anderson, 1989, 92.

53 Andreas and Nadelmann, 2006, 10.

54 Interpol resolution AGN/67/RES/6, Cairo, 1998. 
new policy, terrorist incidents were broken down into their constituent parts, so that their criminal elements could then be identified and subjected to police investigations. ${ }^{55}$

The Interpol "Cairo declaration on terrorism" dating from October 1998, two months after the attacks against the US embassies, was an open condemnation of terrorists around the world, and as such, it was unlike any previous Interpol resolution had been. It presented as key fields of joint action: "the extradition of fugitive terrorists, the sharing of information essential to criminal investigations and to terrorism prevention measures, the detection of all types of traffic in weapons, explosives or other items directly or indirectly connected with the activities of organised terrorist groups, and the adoption of specific criminal charges relating to the use of new technologies for terrorist purposes." ${ }^{56}$

Basically, these were the same fields of action in which Interpol had striven for intensive cooperation throughout its existence. Now they were specifically related to terrorism. According to this new point of view, terrorism could no longer be separated from other types of international crime, since terrorism always constitutes crimes such as murder or arson, which are considered crimes globally. This meant that Interpol had acquired a means to fight terrorism which was not in conflict with the basic principle of Article 3 of its constitution. Terrorist acts were now divided into their criminal elements, and thus they were excluded from the scope of political crimes. Mathieu Deflem has seen this as the reason why the cooperation of the police forces of ideologically very different countries can now be managed through Interpol. ${ }^{57}$

It is worth noting that the year 1998 was also the same year when the role of Europol in the fight against terrorism was confirmed. Terrorism had already been mentioned in the Europol Convention of $1995,{ }^{58}$ but officially terrorism became a part of Europol's mandate in 1998, the year before it commenced its full activities. ${ }^{59}$

In 1999 Interpol, like the UN, tackled the question of the financing of terrorism and reconfirmed its dedication to the battle against terrorism. The 1999 resolution on terrorism financing stated that to provoke a state of terror could not be justified under any circumstances "irrespective of considerations of a political, philosophical, ideological, racial, ethnic, religious or other nature that may be invoked to justify them." 60

55 See also Deflem, 2004, 86.

56 Interpol resolution AGN/67/RES/12, Cairo, 1998.

57 Deflem, 2005.

58 Council Act drawing up the Convention based on Article K.3 of the Treaty on European Union, on the establishment of a European Police Office (Europol Convention), 26 July 1995. (95/C 316/01)

59 Deflem, 2006; Marotta, 1999, 16; Europol official website, www.europol.europa.eu, retrieved on 17 April 2013.

60 Interpol resolution AGN/68/RES/2, The financing of terrorism, Seoul, 1999. 
Since the structure of Interpol is collaborative, the traits of the participating police institutions are visible in its actions. The police agencies of the United States have increasingly been affecting multilateral antiterrorist efforts. They have also contributed to the development of Interpol. Mathieu Deflem has argued that the concerns of the United States, and other parts of the Western industrialised world, became visible in the counterterrorism of Interpol. The heed paid on the fundamentalist Islamic groups is an indication of this. ${ }^{61}$

\subsubsection{The UN and terrorism as unacceptable violence}

During the 1980s and 1990s, similar to Interpol, the UN was forced to take a clearer stand on terrorism. In the early 1980s, the UN General Assembly was still balancing between condemning international terrorism and underlining its causes, as well as the right to self-determination and independence for all peoples "under colonial and racist regimes and other forms of alien domination." 62

Slowly, the discussions on underlying causes were pushed to the side and the UN started to more openly condemn terrorism. The emerging of terrorism on the UN agenda and the involvement of the Security Council in the fight against it have been linked to the end of the Cold War, making international collaboration in the field of peace and security issues easier. Since then, more and more Security Council resolutions were created, while the permanent members decreasingly used their veto power. ${ }^{63}$

61 Deflem, 2004.

62 See e.g. The International Convention Against the Taking of Hostages [Hostage Taking Convention], UN Doc. A/Res/34/146, 1316 UNTS 205, 18 ILM 1456, 17 December 1979. Measures to prevent international terrorism which endangers or takes innocent human lives or jeopardises fundamental freedoms, and study of the underlying causes of the forms of terrorism and acts of violence which lie in misery, frustration, grievance and despair and which cause some people to sacrifice human lives, including their own, in an attempt to effect radical changes, A/RES/36/109, 10 December 1981. Measures to prevent international terrorism which endangers or takes innocent human lives or jeopardises fundamental freedoms, and study of the underlying causes of those forms of terrorism and acts of violence which lie in misery, frustration, grievance and despair and which cause some people to sacrifice human lives, including their own, in an attempt to effect radical changes, A/RES/38/130, 19 December 1983. Measures to Prevent International Terrorism Which Endangers or Takes Innocent Human Lives of Jeopardises Fundamental Freedoms, and Study of the Underlying Causes of Those Forms of Terrorism and Acts of Violence Which Lie in Misery, Frustration, Grievance and Despair and Which Cause Some People to Sacrifice Human Lives, Including Their Own, in an Attempt to Effect Radical Changes, UN GA resolution A/RES/40/61, 9 December 1985. Measures to Prevent International Terrorism Which Endangers or Takes Innocent Human Lives of Jeopardises Fundamental Freedoms, and Study of the Underlying Causes of Those Forms of Terrorism and Acts of Violence Which Lie in Misery, Frustration, Grievance and Despair and Which Cause Some People to Sacrifice Human Lives, Including Their Own, in an Attempt to Effect Radical Changes, A/ RES/42/159, 7 December 1987.

63 Sambei, Du Plessis and Polaine, 2009, 20. 
In 1985, the UN Security Council and General Assembly unanimously adopted important resolutions condemning terrorism. These resolutions were reactions to recent attacks, including those against the Achille Lauro and those committed at the Rome and Vienna airports. ${ }^{64}$ The UN Security Council reacted to the Achille Lauro matter with its first antiterrorist resolution, denouncing all acts of hostage-taking as international terrorism, without making any reference to possible political motives. ${ }^{65}$ The General Assembly resolution also condemned "all acts, methods and practices of terrorism where and by whomever committed." However, the resolution's headline still underlined the need for the states to "contribute to the progressive elimination of the causes underlying international terrorism and to pay special attention to all situations, including colonialism, racism and situations involving mass and flagrant violations of human rights and fundamental freedoms and those involving alien occupation, that may give rise to international terrorism and may endanger international peace and security." It

Reaffirm[ed] also the inalienable right to self-determination and independence of all peoples under colonial and racist regimes and other forms of alien domination, and up[held] the legitimacy of their struggle, in particular the struggle of national liberation movements, in accordance with the purposes and principles of the Charter and of the Declaration on Principles of International Law concerning Friendly Relations and Co-operation among States in accordance with the Charter of the United Nations. ${ }^{66}$

Writing in 1991, Geoffrey Gilbert claimed that the UN was more interested in discussing the backgrounds of terroristic acts than actually condemning these acts. However, it is clear that the UN had started to acknowledge that the POE should have limits with regard to the protection of terrorists. The problem in limiting the exception, however, lay in the fact that terrorism was not a legal concept. ${ }^{67}$ From the late 1980s onwards, the UN antiterrorism conventions had started to constantly apply the aut dedere aut judicare formulation. According to Gilbert, this seemed to prove that a wider policy change was taking place and a new norm of international criminal law was possibly developing. ${ }^{68}$

In 1987, the General Assembly reconfirmed its condemnation of terrorism by declaring that states should cooperate internationally and bilaterally in the

64 Cassese, 1989, 9; Bassiouni, 2001b, Pt. 1, 1. See also Chapter 4, Section 4.2.3.

65 Resolution 579 (1985) on Hostage Taking, UN Doc. S/Res/579, 18 December 1985.

66 Measures to Prevent International Terrorism Which Endangers or Takes Innocent Human Lives of Jeopardises Fundamental Freedoms, and Study of the Underlying Causes of Those Forms of Terrorism and Acts of Violence Which Lie in Misery, Frustration, Grievance and Despair and Which Cause Some People to Sacrifice Human Lives, Including Their Own, in an Attempt to Effect Radical Changes, UN GA resolution A/RES/40/61, 9 December 1985. Italics added.

67 Gilbert, 1991, 133-134.

68 Gilbert, 1991, 8. 
prevention and the combatting of international terrorism, but also that states shall contribute "actively to the elimination of the causes underlying international terrorism." ${ }^{69}$ The General Assembly also drafted a resolution that recommended the organising of a conference to create a definition of terrorism. The US and Israel voted against the proposition because they were concerned that the activities of national liberation movements would be excluded from the definition. Many Third World states, as well as countries of the socialist bloc, still considered it legitimate to use all available means in a fight for self-determination. ${ }^{70}$

In 1989, the General Assembly called attention "to the growing connection between terrorist groups and drug traffickers." ${ }^{" 71}$ The linking of terrorism and other forms of organised crime was a step towards untangling terrorism from its causes and tying it more closely together with its side effects and funding. However, the resolution, including its title that was left intact, still made reference to the causes of terrorism.

In 1990, the UN General Assembly created a Model Treaty on Extradition and the Model Treaty on Mutual Assistance in Criminal Matters, both of which contained the POE. In the Model Treaty on Extradition, this was limited by the 'multilateral treaty obligation.' Both treaties contained the discrimination clause. $^{72}$ In neither instance did the UN make an attempt to further separate the concept of terrorism from the notion of political crime.

In 1991, the UN General Assembly stencil for the antiterrorism resolution titles was finally altered. The previously used long title, underlining the causes of terrorism, was shortened to Measures to Eliminate International Terrorism. ${ }^{73}$ The 1991 resolution discussed the connection between terrorists and drug traffickers "and their paramilitary gangs." However, the underlying causes of terrorism were still discussed.

In 1994, the Declaration on Measures to Eliminate International Terrorism ${ }^{74}$ was the first UN General Assembly resolution not to mention the causes of terrorism. It linked terrorism with other forms of international criminal activities, such as unlawful arms trade and money laundering. The same resolution also

69 Declaration on the Enhancement of the Effectiveness of the Principle of Refraining from the Threat or Use of Force in International Relations, A/RES/42/22, 18 November 1987. Annex, Pt. II, 23.

70 Cassese, $1989,7$.

71 Measures to Prevent International Terrorism Which Endangers or Takes Innocent Human Lives of Jeopardises Fundamental Freedoms, and Study of the Underlying Causes of Those Forms of Terrorism and Acts of Violence Which Lie in Misery, Frustration, Grievance and Despair and Which Cause Some People to Sacrifice Human Lives, Including Their Own, in an Attempt to Effect Radical Changes, A/RES/44/29, 4 December 1989.

72 UN Model Treaty on Extradition, Annex: A/RES/45/116, 14 December 1990; UN Model Treaty on Mutual Assistance in Criminal Matters, Annex: A/RES/45/116, 14 December 1990.

73 Measures to Eliminate International Terrorism, A/RES/46/51, 9 December 1991.

74 UN GA Resolution Declaration on Measures to Eliminate International Terrorism, annexed to the Measures to Eliminate International Terrorism, A/RES/49/60, 9 December 1994. 
interpreted "Acts, methods and practices of terrorism, constitut[ing] a grave violation of the purposes and principles of the United Nations, which may pose a threat to international peace and security, jeopardise friendly relations among States, hinder international cooperation and aim at the destruction of human rights, fundamental freedoms and the democratic bases of society." 75

This declaration demonstrates a reversal in UN policies. Until the 1980s, terrorism was viewed as a method to promote political change in a society, especially in 'colonial' or 'racist' regimes. It could thus be used to further the UN's goal of promoting the right of self-determination. Now the method was denounced as being against UN principles. Further, the same declaration was the first to condemn all terroristic methods irrespective of their possible "political, philosophical, ideological, racial, ethnic or any other nature" motivation that might be considered to justify them. ${ }^{76}$ The following General Assembly resolutions continued with a similar approach. ${ }^{77}$

It is, however, noteworthy that still in the 1994 Declaration, the UN General Assembly called terrorism political: "Criminal acts intended or calculated to provoke a state of terror in the general public, a group of persons or particular persons for political purposes are in any circumstance unjustifiable, whatever the considerations of a political, philosophical, ideological, racial, ethnic, religious or any other nature that may be invoked to justify them." cise the acts themselves but their treatment.

In 1995, the UN General Assembly concluded a new resolution concerning Measures to Eliminate International Terrorism. ${ }^{79}$ In this resolution, the General Assembly expressed that it was "Firmly determined to eliminate international terrorism in all its forms and manifestations." This resolution was an open condemnation of all terroristic methods, "wherever and by whomever committed." The resolution considered terrorist acts criminal but also recognised their political purposes. ${ }^{80}$ In 1997, in the second resolution concerning Measures to Eliminate

75 Pt. I (2), UN GA Resolution Declaration on Measures to Eliminate International Terrorism, annexed to the Measures to Eliminate International Terrorism, A/RES/49/60, 9 December 1994.

76 Pt. I (3), UN GA Resolution Declaration on Measures to Eliminate International Terrorism, annexed to the Measures to Eliminate International Terrorism, A/RES/49/60, 9 December 1994.

77 See e.g. Pt. I (2), UN GA Resolution Measures to Eliminate International Terrorism, A/ RES/51/210, 17 December 1996; para (2), Measures to Eliminate International Terrorism, UN Doc. A/Res/51/210, 16 January 1997; para (2), Measures to Eliminate International Terrorism, A/RES/54/110, 9 December 1999; para (2), Measures to Eliminate International Terrorism, A/RES/58/81, 9 December 2001; para (2), Measures to Eliminate International Terrorism, A/RES/57/27, 19 November 2002.

78 Article 1, Declaration on Measures to Eliminate International Terrorism, annexed to the Measures to Eliminate International Terrorism, A/RES/49/60, 9 December 1994. Italics added.

79 Measures to Eliminate International Terrorism, UN Doc. A/RES/49/60, 17 February 1995.

80 Annex, Measures to Eliminate International Terrorism, UN Doc. A/RES/49/60, 17 February 1995. See also Nuotio, 2006, 1003. 
International Terrorism, terrorism was again condemned and the thought that any political or other justifications do not condone terrorism repeated. Additionally, this resolution made note that the 1951 Refugee Convention did not protect those that had committed terrorist acts. Further, it underlined the importance of prosecuting all terrorists and not providing them with asylum. ${ }^{81}$

After the 1998 terrorist attacks in Tanzania and Kenya, the UN created the Terrorist Bombings Convention, ${ }^{82}$ which reaffirmed the General Assembly Resolution 49/60 denouncing "all acts, methods and practices of terrorism as criminal and unjustifiable, wherever and by whomever committed." 83 As terrorist bombings, qualified acts where "Any person commits an offence within the meaning of this Convention if that person unlawfully and intentionally delivers, places, discharges or detonates an explosive or other lethal device in, into or against a place of public use, a State or government facility, a public transportation system or an infrastructure facility: (a) With the intent to cause death or serious bodily injury; or (b) With the intent to cause extensive destruction of such a place, facility or system, where such destruction results in or is likely to result in major economic loss." Assistance or participation in such acts was also condemned. ${ }^{84}$ The Terrorist Bombing Convention made a point to underline that the acts in question were "under no circumstances justifiable by considerations of a political, philosophical, ideological, racial, ethnic, religious or other similar nature and are punished by penalties consistent with their grave nature." 85 The discrimination clause was still used. ${ }^{86}$

The Terrorist Bombings Convention was the first UN convention to depoliticise specific acts of terrorism. I make this claim based on three different elements present in the text of the convention. First, the convention did not make reference to the grievances causing the acts, unlike so many UN conventions in the earlier decades. It is clear that the UN still acknowledged the political motivations of terrorism, but such motivations no longer meant that the acts would have been considered legitimate. Second, political motivations did not form part of the constituent elements of the acts. Thus this convention was the first to use the term terrorist with regard to violent acts without an evident political motivation. Finally, the convention excluded terroristic bombings from the scope of the POE, being the first UN convention to do this. In other words, the depoliticisation was done by (1) pushing aside the political motives behind terrorist acts, (2) defining a terrorist act without reference to political motives and (3) excluding

81 Measures to Eliminate International Terrorism, UN Doc. A/RES/51/210, 16 January 1997 and Annex.

82 Convention for the Suppression of Terrorist Bombings (Terrorist Bombing Convention), UN Doc. A/RES/52/164, 9 January 1998.

83 Declaration on Measures to Eliminate International Terrorism, annexed to the Measures to Eliminate International Terrorism, UN Doc. A/RES/49/60, 9 December 1994.

84 Article 2, Terrorist Bombing Convention, UN Doc. A/RES/52/164, 9 January 1998.

85 Article 5, Terrorist Bombing Convention, UN Doc. A/RES/52/164, 9 January 1998.

86 Article 12, Terrorist Bombing Convention, UN Doc. A/RES/52/164, 9 January 1998. 
the defined terrorist acts from the scope of the POE. However, the convention did not openly depoliticise the acts by stating that they would not by nature be political, but that they would not be considered political only "for the purposes of extradition or mutual legal assistance." 87

The year 1999 confirmed the policy change. The UN Security Council condemned terrorism as a threat to peace and security of mankind. ${ }^{88}$ The Terrorism Financing Convention ${ }^{89}$ of the same year was the first UN convention to have defined terrorism, even if the definition has not, to date, been accepted as the official UN terrorism definition. Debate over whether the definition represented a consensus between member states persists. ${ }^{90}$ Terrorism, according to the UN, constitutes acts covered by previous multilateral conventions, as well as "Any other act intended to cause death or serious bodily injury to a civilian or to any other person not taking an active part in the hostilities in a situation of armed conflict, when the purpose of such act, by its nature or context, is to intimidate a population, or to compel a government or an international organisation to do or to abstain from doing any act." ${ }^{91}$ Here, the special intent requirement did not necessitate a political motivation as such: terrorising a population or coercing a government for an entirely private reason, for instance, extortion is also possible. However, as pointed out by Saul, the definition would still typically relate to violence committed for ideological reasons. ${ }^{92}$ Cohen has argued that the definition acknowledges the political nature of the acts without using the term political. Furthermore, it does not limit terrorist acts to known types of violent behaviour but is wide enough to encompass for example cyberterrorism and other possible future manifestations of terrorism..$^{93}$

Additionally, the treatment of these acts was depoliticised: Article 6 of the convention requires parties to adopt domestic legislation "to ensure that criminal acts within the scope of this Convention are under no circumstances justifiable by considerations of a political, philosophical, ideological, racial, ethnic, religious or other similar nature." ${ }^{94}$ Additionally, Article 14 addressed the political offence exception and declared that none of the defined crimes "shall be regarded for the purposes of extradition or mutual legal assistance as a political offence or as an offence connected with a political offence or as an offence inspired by political

87 Article 11, Terrorist Bombing Convention, UN Doc. A/RES/52/164, 9 January 1998.

88 UN Security Council Resolution 1269 On the Responsibility of the Security Council in the Maintenance of International Peace and Security, UN Doc. S/RES/1269, 19 October 1999.

89 Convention for the Suppression of the Financing of Terrorism, UN Doc. A/54/109, 9 December 1999.

90 Cohen, 2012, 235.

91 Convention for the Suppression of the Financing of Terrorism, UN Doc. A/54/109, 9 December 1999.

92 Saul, 2007, 2.

93 Cohen, 2012, 234.

94 Article 6, Convention for the Suppression of the Financing of Terrorism, UN Doc. A/54/109, 9 December 1999. 
motives." Thus the convention denied the possibility to refuse extradition on the basis that the offence in question was a political offence. ${ }^{95}$ The 1999 convention thus followed the convention of the previous year in its depoliticisation of terrorism and also restricted the depoliticisation of the said offences to the application of extradition and mutual legal assistance treaties.

In 2000, the UN made a new attempt at creating a comprehensive convention on international terrorism. The draft was never ratified. In the draft, terrorism was defined in similar terms as in the Terrorism Financing Convention, but also "Serious damage to a State or government facility, a public transportation system, communication system or infrastructure facility with the intent to cause extensive destruction of such a place, facility or system, or where such destruction results or is likely to result in major economic loss." As in the 1999 convention, the motivations or the acts were not mentioned, but the purposes were to either "intimidate a population or to compel a Government or international organisation to do or abstain from doing any act." ${ }^{96}$ Similar to the Terrorism Financing Convention, the Draft Comprehensive Convention excluded terroristic crimes from the scope of the POE. ${ }^{97}$ It also excluded the crimes previously dealt with in UN conventions from the scope of the POE. ${ }^{98}$ The obstacle for the creation of a comprehensive definition persistently has been the disagreement between states on whether to include violence conducted by states against their own citizens and whether an exception in cases of opposition to foreign occupation could be acceptable. ${ }^{99}$

In contrast, for instance the Organisation of African Unity (OAU) in its Convention on the Prevention and Combating of Terrorism of 1999 excluded those fighting for liberation or self-determination, "including armed struggle against colonialism, occupation, aggression and domination," from being terrorists, "subject to provisions of international law." 100 Otherwise, the OAU convention was akin to other antiterrorist conventions of the time. It underlined the need to reject "all forms of terrorism irrespective of their motivations." Further, "Political, philosophical, ideological, racial, ethnic, religious or other motives shall not be a justifiable defence against a terrorist act."101 The OAU defined terrorism without an outspoken reference to political goals, but similar to, for

95 Article 14, Convention for the Suppression of the Financing of Terrorism [Terrorism Financing], UN Doc. A/54/109, 9 December 1999.

96 Article 2, Draft Comprehensive Convention on International Terrorism, UN Doc. A/C.6/55/1, 28 August 2000.

97 Article 14, Draft Comprehensive Convention on International Terrorism, UN Doc. A/C.6/55/1, 28 August 2000.

98 Annex I, Draft Comprehensive Convention on International Terrorism, UN Doc. A/C.6/55/1, 28 August 2000.

99 Cohen, 2012, 231-232; Saul, 2015, 399. See for a commentary of the Draft Convention Ambos and Timmerman, 2014, 32-35.

100 Article 3 (1), Organisation of the African Unity Convention on the Prevention and Combating of Terrorism, l July 1999.

101 Article 3 (2), Organisation of the African Unity Convention on the Prevention and Combating of Terrorism, l July 1999. 
instance, the later drafted 2002 European Union (EU) definition, it classified as terrorist a number of violent acts with the intention to "(i) intimidate, put in fear, force, coerce or induce any government, body, institution, the general public or any segment thereof, to do or abstain from doing any act, or to adopt or abandon a particular standpoint, or to act according to certain principles; or (ii) disrupt any public service, the delivery of any essential service to the public or to create a public emergency; or (iii) create general insurrection in a State." ${ }^{102}$ The articles dealing with extradition of the OAU Convention did not discuss the POE at all. ${ }^{103}$

Similar to the OAU, the Convention of the Organisation of the Islamic Conference on Combating International Terrorism of 1999 excluded from its definition "armed struggle against foreign occupation, aggression, colonialism, and hegemony, aimed at liberation and self-determination," similarly, which is noteworthy, "in accordance with the principles of international law." This convention contained a long list of crimes which "In the implementation of the provisions of this Convention [...] shall not be considered political crimes even when politically motivated." These included the traditional Belgian clause covering government members other than heads of states and the internationally protected persons clause. Interestingly, the following acts were also considered non-political: “4 . Murder or robbery by force against individuals or authorities or means of transport and communications; 5 . Acts of sabotage and destruction of public properties and properties geared for public services, even if belonging to another Contracting State; 6. Crimes of manufacturing, smuggling or possessing arms and ammunition or explosives or other materials prepared for committing terrorist crimes." 104

In comparison, the preamble of the 1998 Mercosur extradition treaty stated: "Teniendo presente la evolución de los Estados democráticos tendiente a la eliminación gradual de los delitos de naturaleza politica como excepción a la extradición." Considering that the treaty was drawn in 1998, it is interesting to see such a statement. In the treaty text itself, the political offence exception is still acknowledged but limited by the multilateral treaty clause, the Belgian clause and references to specific UN antiterrorist conventions. Additionally, war crimes, crimes against humanity and genocide are excluded from the POE. In addition to these more common exclusions, the Mercosur treaty also excluded "en general, cualquier acto no comprendido en los supuestos anteriores cometido con el propósito de atemorizar a la población, a clases o sectores de la misma, atentar contra la economía de un país, su patrimonio cultural o ecológico, o cometer

102 Article 1 (3) (a), Organisation of the African Unity Convention on the Prevention and Combating of Terrorism, l July 1999.

103 Articles 8-13, Organisation of the African Unity Convention on the Prevention and Combating of Terrorism, l July 1999.

104 Convention of the Organisation of the Islamic Conference on Combating International Terrorism, Annex to Resolution No: 59/26-P, 1 July 1999. 
represalias de carácter político, racial o religioso."105 In other words, threatening the economy of a country, for instance, could be considered terrorism.

A very wide understanding of terrorism was held by the 1999 Treaty on Cooperation among the States Members of the Commonwealth of Independent States in Combating Terrorism, which defined the aims of terrorism as "committed for the purpose of undermining public safety, influencing decision-making by the authorities or terrorising the population." The definition offered by the treaty included, for instance, property damage that could endanger human lives, threats to the lives of any public figures for a reason relating to their official position or to those of representatives of foreign states, and "other acts classified as terrorist under the national legislation of the Parties or under universally recognised international legal instruments aimed at combating terrorism." In addition, the treaty considered "technological terrorism" which involved the use of different weaponry such as chemical or biological weapons if the acts in question were "committed for the purpose of undermining public safety, terrorising the population or influencing the decisions of the authorities in order to achieve political, mercenary or any other ends." 106 Finally, it was agreed that "In cooperating in combating acts of terrorism, including in relation to the extradition of persons committing them, the Parties shall not regard the acts involved as other than criminal."107 This formulation is of interest because it seemingly aims at depoliticising terrorist acts but does not openly do it, while at the same time the potential political ends are acknowledged in the definition. All in all, the definition does align with other new definitions of the same period.

It is worth noting that the developments within the Arab League were in stark contrast with those of other international organisations. The Arab League has already excluded terrorism from the scope of political offences in 1952, but in 1983, the Riyadh Arab Convention on the Judicial Co-operation no longer mentioned terrorism specifically. It, however, held on to the unqualified attentat clause by not considering as political crimes: " 1 . Assault on kings and presidents of the contracting parties or their wives or their ascendants or descendants; 2 . Assault on heirs apparent or vice-presidents of the contracting parties. 3. Murder and robbery committed against individuals, authorities, or means of transport and communications." This was done "In the application of the provisions of

105 In other words, the treaty claims that democratic states are gradually eliminating crimes of a political nature as exceptions to extradition and excludes "in general" acts that aim at frightening the population [NB! Without an overt mention of terrorism] or specific groups, threatening the economy of a country or its cultural or ecological heritage and acts that serve as reprisals of a political, racial or religious nature. Article 5 (2) (c), Acuerdo sobre extradición entre los estados partes del Mercosur, 10 December 1998.

106 Article 1, Treaty on Cooperation among the States Members of the Commonwealth of Independent States in Combating Terrorism, 4 June 1999. Italics added.

107 Article 4, Treaty on Cooperation among the States Members of the Commonwealth of Independent States in Combating Terrorism, 4 June 1999. 
this Agreement" and "even when [these crimes] have a political purpose."108 In other words, for some reason, the Arab League decided to discard the notion of terrorism just as the rest of the world started to use it.

\subsubsection{Why was terrorism depoliticised?}

It has thus been demonstrated that the depoliticisation has been (close to) a worldwide strategy for encountering terrorism, especially since the late 1990s. What purposes does the depoliticisation of terrorism then serve? Why has it been so commonly employed? Does it stem from an intrinsic thought that the motive of the crime would make a difference to how the deed is judged? Earlier in the chapter, I state that terrorism has in fact often been seen as more wrongful due to its political intentions. Would it be possible to see it as less wrong due to its political motives? ${ }^{109}$ Is there still an underlying notion regarding the heroism of the political offender?

According to Ondřej Ditrych, in the early 21st century: "Terrorism has been successfully depoliticised by the near-exclusive focus on means rather than ends, which can be traced back to previous First World discourse, and also through the transformation of 'root causes', once a discourse of resistance, into a progressivist yet not revolutionary discourse of development and poverty eradication, based on the normalising premise that there is no place for terrorism in the 'developed' world." 110

It seems that the depoliticisation of terrorism has become the most acceptable global strategy, as it helps to ignore the causes that fuel acts of terrorism and facilitates international collaboration against it, removing the need to disagree on the political goals sought.

In the 1970s, when the political nature of terrorism was widely discussed, international collaboration against it was difficult or even implausible. For this reason, writing in 1975, Bart DeSchutter argued that more pertinent than the analysis of the motives of terrorism was the creation of legal measures against it. He argued, "It is unlikely that the very roots of terrorism will ever be agreed upon. Every effort must be made to avoid reducing the issue to a political question."111

When the definition of terrorism does not require a political motive, it is possible to avoid the debate over what the term 'political' means. The only common

108 Article 41, League of Arab States, Riyadh Arab Agreement for Judicial Cooperation, 6 April 1983.

109 For instance Michael Freestone has argued that both views are possible: “Terrorist acts will generally be clear violations of national criminal laws, but the explicit political motives of the offender render them different in kind from other offences. The difference will plainly depend upon the observer's stance: the political motive may make the offence excusable or it may make it appear more heinous than a comparable 'common' offence." Freestone, 1981, 195.

110 Ditrych, 2013, 230.

111 DeSchutter, 1975, 379. 
understanding seems to be that indiscriminate or atrocious violence, violence that is too remote from, or disproportionate to, a political end, should not be understood as a political crime for the purposes of applying the POE. ${ }^{112}$

The depoliticisation also serves another purpose, which is to diminish the offenders and to make severe actions against them seem natural and necessary. Carl Schmitt argued in 1932 that the adversary can be described as non-political to make them sound harmless, "or vice versa if one wants to disqualify or denounce him as political in order to portray oneself as nonpolitical (in the sense of purely scientific, purely moral, purely juristic, purely aesthetic, purely economic, or on the basis of similar purities) and thereby superior." turns the battle against it into a 'technical' matter and removes it from the sphere of public debate because it makes the acts against it non-political as well.

Schmitt, who was critical of liberalist tendencies, linked all depoliticisation with the rise of liberalism. He saw depoliticisation as the goal of liberalism. In fact, he saw liberalism as characterised by the negation of the political. ${ }^{114}$ It is possible to understand that the less there is 'political' in the society, the more 'manageable' the society becomes, as the lack of political also means the lack of the friend-enemy antagonism.

The depoliticisation and 'trivialisation' of terrorism can be seen as a way to diminish the goals of terrorists. Even outspoken political goals can be weakened by claiming that the people aiming at these goals are mere criminals. This can lead to the disappearance of the whole notion of political terrorism. The political goals of terrorists have not disappeared, but these goals are not acknowledged or accepted as political by the decision makers. ${ }^{115}$ For instance, when discussing the US-UK supplementary extradition treaty of 1985, it was argued that turning the extradition of a terrorist into a political matter seemed to prove that they were acknowledged as political actors. ${ }^{116}$

For police cooperation purposes, depoliticisation facilitates collaboration, as the political nature of the deeds can be forgotten. This allows for the police to concentrate on the 'technical' side, capturing criminals. This viewpoint is visible in the English delegation's statement at the Rome Anti-Anarchist Conference of 1898: “Une définition n’est pas nécessaire et serait inutile. Nous ne poursuivons pas l'opinion. Pour nous, la seule question est celle-ci: y a-t-il crime, oui ou non? Si l'acte est criminel, tel que meurtre ou l'exitation au meurtre, il ne le devient pas davantage par le fait qu'il provient de l'anarchisme. S'il n'est pas criminel, in ne le devient pas par le fait qu'il est anarchique." 117 What difference does the political motivation make if the crime committed is, for instance, a murder?

112 See also Saul, 2006, 42-43.

113 Schmitt, 1996 (1932), 32.

114 Strauss, 1996, 84.

115 Stohl, 1988, 12-13.

116 Gilbert, 1991, 163-164; Gilbert, 1998, 332.

117 Cited in Tamburini, 1997, 242; and in Di Paola, 2007, 90. 
Also Alex Conte and Boaz Ganor have justifiably posed the question why to even talk about terrorism at all: "An act of 'terrorism', after all, will comprise a series of acts that, in and of themselves, constitute various criminal offences. To take an example, a bombing of an Embassy will likely involve the unlawful possession of explosives, the wilful destruction of property and the wilful injury to or killing of persons. Each element is a criminal offence in most jurisdictions and, as such, is capable of being dealt with by the relevant municipal jurisdiction."118

According to some, the depoliticisation is useful from a human rights point of view, as concentrating on motives can easily lead to law enforcement and intelligence agencies racially, religiously or politically profiling people, leading to discrimination and suspicion. Additionally, concentrating on motives brings politics to investigations and to trials, and contradicts with freedoms so dearly valued in democratic societies such as the freedom of expression, association and religion. ${ }^{119}$ Then again, if terrorists indeed attack the heart of democratic values, why is there a need to act 'neutral' when bringing them to justice? Is the rule of law not based on certain outspoken values, not on some 'natural' principles completely separate from all political concerns?

As shown in this book, in Anglo-American jurisprudence, the interpretation of the POE has been left to the courts. Even if the historically applied incidence test has been the starting point for the courts' interpretations, they have developed flexibility towards its application both in a restrictive and an expansive manner. The Kolczynski case involving the Polish seamen is an example of the expansive interpretation, whereas the cases of Meunier, Cheng and Ornelas v. Ruiz represent the restrictive interpretation, in which the political agenda of the offenders has been judged unacceptable. This flexibility of the courts proved to be problematic, as there were both supporters and opponents of each political cause in the US. ${ }^{120}$ This can be seen as one reason for the depoliticisation of terrorism: dealing with all terrorist acts in the same way, regardless of their perpetrators' political motivations, could lessen internal and international tensions.

One of the ways in which it is possible to use the depoliticisation strategy without denying the political nature of terrorism is to use the 'exception to the exception' formula. As described earlier, the formula is as follows: crime X, notwithstanding its political character, and in derogation from the political offence exception, will always be liable to extradition. The use of this formula does not deny the political nature of the acts, it merely states that extradition is still possible. The problem with this formula is naturally the lack of a definition of terrorism that would be accepted worldwide, so that the concept 'terrorism' could simply replace the 'crime $\mathrm{X}$ ' in the formulation. Until a definition exists, the exception to exception formula can only be used with a listing of specific offences that are typically considered terroristic. An easier and an apparently more viable way to

118 Conte and Ganor, 2005.

119 Saul, 2008, 1.

120 Epps, 1988, 205. 
exclude acts of terrorism from the scope of the exception would be to deny the protection of the POE for 'wanton acts' of violence or to use the predominance test. Both of these have successfully been applied by courts.

The reason for the reluctance to call terrorists political criminals may be the fear that if one is known to accept the existence of the political goals of terrorists, they could be viewed as a supporter of these goals or even the terroristic methods. According to Ben Saul, many states have been concerned that labelling offenders as political could be interpreted as a legitimisation of their actions. ${ }^{121}$ For this reason, taking away the political label from terrorism reduces them to mere criminals. For instance, Kelly Anne Moore of the New York Times argued that "Those who commit terrorist acts should be tried as the criminals they are, instead of the 'warriors' they claim to be. If the Guantánamo detainees were prosecuted in federal courts instead of being designated as 'combatants,' most by now would be serving prison time as convicted terrorists, instead of being celebrated as victims or freedom fighters." 122 A similar view was presented by Minister for Foreign Affairs of Denmark Villy Søvndal, EU Counter-terrorism Coordinator Gilles de Kerchove and UN Special Rapporteur Ben Emmerson in their article published in Le Monde in 2012. They argued that once terrorists are treated as criminals instead of combatants, resorting to terrorism will lose its attraction. ${ }^{123}$

According to Jan Klabbers, "there is, in the end, something rather unsavoury about subjecting political adversaries to criminal law: that may be what dictators and tyrants do, but it is far from commendable." 124 Additionally, Klabbers has pointed out that "international law has great difficulty in deciding whether terrorists should be treated as ordinary criminals or as political actors." 125 The problem is an eternal one: “Today's terrorist is tomorrow's freedom fighter." This is true as contexts of judgment, can and do change. ${ }^{126}$ Klabbers's statement is supported by the views of Martti Koskenniemi. Koskenniemi argues that in today's politically and religiously divided world it is easier to not bring out the ideological side of issues, but to rather treat the opponent as a criminal. Thus a political statement is shaded with the seemingly impartial cloak of justice. ${ }^{127}$

Klabbers interestingly notes that "Th[e] political element facilitates a curious symbiosis between the terrorist and the political authorities on the other side of the fence, in two ways: both the terrorist and the authorities have an interest both in playing down the political element and in blowing it up; therewith, terrorists ultimately reinforce the state and the state ends up reinforcing terrorists." From the point of view of the terrorist, according to Klabbers, the depoliticisation of

121 Saul, 2006, 39.

122 New York Times, 21 August 2007, "Take Al-Qaeda to court."

123 "Dés lors que ces derniers sont traités comme des criminels et non comme des "combattants," le terrorisme perd de son attrait." Søvndal, de Kerchove and Emmerson, 2012.

124 Klabbers, 2003, 302.

125 Klabbers, 2003, 299.

126 Klabbers, 2003, 301.

127 Helsingin Sanomat, 12 August 2014, “Oikeutta käytetään myös sodankäynnin strategiana.” 
their acts means that they are less sought for and may receive a less severe punishment. Then again, at the same time, the recognition of a criminal as a terrorist brings out their political considerations. For state authorities, the problem is essentially the opposite. The depoliticisation of terrorism makes the act less public and thus reduces the impact of the desired message. Treating terrorism as common criminality also makes it a domestic matter, instead of bringing it to the international sphere. Then again, the search for common criminals means that less severe means can be used when they are sought for. As Klabbers writes: "Surely, one does not throw bombs on other nations to find a common criminal: the language of terrorism is necessary in order to justify a large scale response." For these reasons, there is an interesting interdependence between the terrorist and the state, which makes it difficult to create suitable legal instruments. ${ }^{128}$

The depoliticisation of terrorism is not an easy solution that would solve all problems relating to encountering the terrorist threat. Christine van den Wijngaert has criticised the depoliticisation of terrorism from a criminological point of view and called it "legal fiction." Should political criminals be punished, they typically see themselves as more like "prisoners of war" of the system, instead of as people who are held responsible for their crimes against society. This is an important issue to acknowledge when planning the prevention and punishment of political crime. For this reason, according to Van den Wijngaert, the "fictive assimilation" of political and common offenders is not useful. ${ }^{129}$

In contrast to the international trend of defining terrorism based on the physical or objective acts, some have argued that the motive element should be a part of definitions of terrorist offences as it helps to distinguish terrorism from other kinds of serious violence that can also spread terror. It would also correspond with the general understanding of what terrorism is. There is a moral difference between acts committed for ideological reasons and with acts committed for private ends. For this reason, this difference should also be visible in criminal law. ${ }^{130}$

For instance, Saul has suggested that there could be a way of depoliticising acts of terrorism for the purposes of extradition while still holding on to the thought that the act consists of terrorism due to its political motive. ${ }^{131}$ This would allow the delegitimisation of the use of terrorist means, together with the condemnation the terrorists' anti-democratic goals.

Considering terrorism political seems to put some weight, or even legitimacy, to the grievances that are seen to promote terrorist actions. ${ }^{132}$ Some writers have indeed seen terrorists as the oppressed, even if their actions are criminal and condemnable. ${ }^{133}$ This view should not be banned from debates that concern ter-

128 Klabbers, 2003, 307-308.

129 Van den Wijngaert, 1980, 32, 36.

130 See Saul, $2008,2$.

131 Saul, 2006, 43-44.

132 Bassiouni, 2001, 25; Wight, 2015, 3.

133 Bay, 1989, 48. 
rorists. It is and should be possible to accept that terrorists also need their voices heard, or even to sympathise with their goals, without accepting the violent means they use. ${ }^{134}$ Naturally, as in any normal political debate, it should also be possible to hear the grievances of terrorists, and either agree or disagree with them.

Even if requiring a political motive is in many ways problematic from a legal perspective, this would allow for the society to express its values through its legislation and underline the wrongfulness of the acts. Presumably, the final aim of depoliticisation has not been to suggest that actions of terrorism have nothing to do with politics, but to underscore the idea that no ideology justifies the use of terrorist tactics. However, it could be argued that just the opposite is true. In Colin Wight's words: "Yet, the modern state also embodies a particular account of politics and of sovereign authority that is itself a reflection of a particular European, and largely secular, way of thinking about political order. Given this, it is not difficult to see contemporary international terrorism, particularly in its Islamic form, not as an expression of religious fanaticism, but of a competing vision of what politics is and should be. Thus contemporary international terrorism represents a challenge not just to particular states, but also to the very understanding of politics itself; as such it is also a challenge to the very idea of the modern state." 135

Saul has underlined the expressive function of criminal law. According to him: "a conviction for political violence sends a symbolic message that certain kinds of violence, as such, cannot be tolerated and reinforces the ethical values of the political community." 136 Similarly, according to Murphy, even if terrorists are not likely to be deterred by the prospect of punishment, criminalising terrorism serves the purpose of condemning such acts and can be used as a tactic of 'ideological warfare' against terrorism. ${ }^{137}$ In contrast, treating political offenders as criminals without ideological motivations seems to put aside the idea of a nation built on specific political ideas. Why has this strategy then be used with regard to those offenders democratic nations most would wish to condemn, terrorists?

\subsection{Dismantling the political offence exemption}

\subsubsection{Terrorism as an 'evil ideology' since 2001}

The attacks against the World Trade Centre and Pentagon in the US on 11 September 2001 constituted one of the most momentous terrorist events of all times. They provoked a widespread wave of condemning reactions from around the world. The Interpol Secretary General Ronald Noble argued that they "constituted attacks against the entire world and its citizens."138

134 See also Wight, 2015, 8.

135 Wight, 2015, 21.

136 Saul, 2006, 39.

137 Murphy, 1985, 2.

138 Cited in Deflem, 2006. 
The attacks caused a narrowing of the debates on terrorism. Terrorism was now explained by the 'evil mindset' of the perpetrators. According to Arun Kudnani, "Terrorism became an 'evil ideology' that did not require further analysis." 139 The radicalisation discourse focuses on the individual, and to some extent, the ideology and the group the individual associates with, rather than the 'root causes' of terrorism, ${ }^{140}$ which used to be the focus of terrorism-related debates in the past. The radicalisation debate no longer left room to consider terrorism as a form of political action. ${ }^{141}$

The terrorist acts of September 2001 also generated an unforeseen flow of antiterrorist legislation and tools, and pushed international antiterrorist cooperation to a new high. They also, as claimed by this book, gave, by proxy, a deadly blow to the POE within EU states. At the same time, the number of Interpol resolutions and UN conventions on terrorism grew substantially. ${ }^{142}$ Resolutions drafted by both organisations in the wake of the attacks confirmed a new policy that had gradually started to form since the mid-1980s. The Interpol General Assembly meeting confirming the new attitude towards terrorism took place just two weeks after the attacks (24-28 September). This is perceptible, as the resolution concentrated on honouring the victims and declaring the attacks as a violent mass murder and a crime against humanity. The possibility of the crimes being of political nature was not mentioned in the resolution; Article 3 was no longer central. ${ }^{143}$

Similarly, the UN Security Council in its Resolution 1368 on 12 September 2001, only a day after the attacks took place, condemned all terrorist acts as "threats to international peace and security" and called for all states to join the effort of fighting terrorism. ${ }^{144}$ Just two weeks later, Resolution 1373 was adopted unanimously. This resolution gave a new, quasi-legislative and highly controversial role to the Security Council, as it contained detailed and legally binding obligations to the legislators of member states. It also created the Counter-Terrorism Committee (CTC) aimed at strengthening the counterterrorism capacities of member states. The CTC consists of the fifteen member states of the Security Council. ${ }^{145}$ In November, the Security Council Resolution 1377 condemned all acts of terrorism "regardless of their motivation" as "contrary to the purposes and

139 Kudnani, $2012,4$.

140 Kudnani, 2012, 6.

141 Kudnani, 2012, 21.

142 Out the 17 antiterrorism resolutions of Interpol from between 1951 and 2017, 7 have been written since 2001. Out of the $19 \mathrm{UN}$ antiterrorism conventions from between 1963 and 2017, 7 have been concluded since 2001 .

143 AG-2001-RES-05, Budapest, 2001.

144 Threats to International Peace and Security Caused by Terrorist Acts, S/RES/1368, 12 September 2001.

145 UN Security Council Resolution 1373 Threats to International Peace and Security Caused by Terrorist Acts, UN Doc. S/RES/1373, 28 September 2001. See also Sambei, Du Plessis and Polaine, 2009, 21. 
principles of the Charter of the United Nations."146 It was thus immediately clear that these attacks turned out to be a crisis for the whole world and for the way in which terrorism was fought.

\subsubsection{The EAW of 2004 and the annibilation of the POE}

As described in Chapter 4, Section 4.1.5, changes within the European collaboration structures with regard to the POE had begun with the creation of the ECST in 1977. Finally, it was the new type of terrorist threat since the early years of the 2000s that brought the practice of protecting political offenders to an end.

After the attacks against the US in 2001, a variety of European organs started to reformulate their stance against terrorism. The EU reaction was quick and comprehensive. Together with the explosions of bombs on passenger trains in Madrid in 2004 and London 2005, the events of September 11 put the fight against terrorism on top of the EU agenda. ${ }^{147}$ Some have even argued that they created a shift in the whole governance of the EU. ${ }^{148}$

The European Council adopted an Action Plan, and the Justice and Home Affairs Council formed conclusions that set the main lines of action for the EU only ten days after $9 / 11$. Altogether 68 measures, mostly regarding collaboration in criminal matters, were listed in the so-called road map that was to be updated on a regular basis. ${ }^{149}$ These included the framework decision on the European Arrest Warrant (EAW), the Framework Decision on Combating Terrorism, and the EU-US agreements on extradition and mutual legal assistance. ${ }^{150}$

In addition to the EU, the Committee of Ministers of the Council of Europe condemned the terrorist attacks and began consideration for specific actions that could be taken to counter "such monstrous acts."151 A Multidisciplinary Group on International Action against Terrorism (GMT) working under the authority of the Committee of Ministers was established, and the Parliamentary Assembly of the Council of Europe adopted two texts in 2001: Resolution $1258^{152}$ and Recommendation $1534^{153}$ on Democracies Facing Terrorism, showing the dedication of the Council of Europe in the international fight against terrorism. In 2002, the Council of Europe adopted two important texts for the functioning

146 Declaration on the Global Effort to Combat Terrorism, S/RES/1377, 12 November 2001.

147 Wouters and Naert, 2001, 5.

148 Kaurnet, 2010, 253.

149 See Wouters and Naert, 2004, 909.

150 Wouters and Naert, 2001, 4.

151 Explanatory Report to the European Convention on the Suppression of Terrorism, ETS No. 90, 27 January 1977.

152 Parliamentary Assembly of the Council of Europe Resolution 1258 on Democracies Facing Terrorism, 26 September 2001.

153 Parliamentary Assembly of the Council of Europe Recommendation 1534 on Democracies Facing Terrorism, 26 September 2001. 
of the GMT, Recommendation 1550 on Combating Terrorism and Respect for Human Rights, ${ }^{154}$ and the Guidelines on Human Rights and the Fight Against Terrorism. ${ }^{155}$

The terrorist attacks of 2001 also brought about the creation of new forms of collaboration such as the Counter Terrorist Group (CTG). The CTG was initiated by members of the 'Club of Berne,' bringing together heads of the security and intelligence services across Europe. It provides for cooperation in terrorism matters on the basis of an extralegal memorandum of understanding. Also, the Counter-Terrorism Task Force agreed upon already in 1998, became fully operational after the attacks. It brings together EU member states' police and intelligence service terrorism experts. ${ }^{156}$

In addition to strengthening EU organs and creating new ones for the purposes of the fight against terrorism, the attacks of 2001 also fuelled legislative reforms. On the 21 September 2001, the European Council agreed that it was necessary to create a European definition of terrorism. In less than a year, the Framework Decision on Combating Terrorism ${ }^{157}$ of 13 June 2002 was finalised and later in December its provisions were already meant to be transposed into national laws.

The Framework Decision defined terrorism for the first time. The definition contains two elements: the objective and the subjective. The objective element of a terrorist act is a serious, typically violent crime such as murder, the infliction of bodily injuries, hostage-taking, extortion or a threat to commit any of these crimes. The subjective element is the aim of the act, which is to seriously intimidate a population, destabilise or destroy structures of a country or international organisation, or make a government abstain from performing actions. The definition also included property damage, but it was limited to "extensive destruction" or crimes "likely to endanger human life or result in major economic loss."158

The subjective element in the European Council definition could be interpreted as a political aim, as affecting the government's structures or decisionmaking is typically understood as a political act even if it can also be done for other, personal reasons. Going back to the classical definition of 'political crime,' an illegal act with the intent to oppose the state, ${ }^{159}$ the EU definition of terrorism

154 Parliamentary Assembly of the Council of Europe Recommendation 1550 on Combating Terrorism and Respect for Human Rights, 24 January 2002.

155 Committee of Ministers of the Council of Europe, Guidelines on Human Rights and the Fight Against Terrorism, H (2002) 4, 11 July 2002.

156 Deflem, 2006.

157 Council Framework Decision of 13 June 2002 on Combating Terrorism, 2002/475/JHA, OJ L 164, 22 June 2002, pp. 3-7. See for a more detailed discussion on the Framework Decision e.g. Wouters and Naert, 2004.

158 Article 1(1), Framework Decision on Terrorism, 2002/475/JHA, OJ L 164, 22 June 2002.

159 See Chapter 2, Section 2.1. See also e.g. Garcia-Mora, 1962, 1226. 
would fit the category well. However, the motivations of the terrorist acts are not discussed in the definition, possibly because they would be difficult to prove in court, but also possibly because of the existence of the POE.

Interestingly, in the Proposal for the Framework Decision, it was underlined that a terrorist offence differs from an ordinary criminal offence by its motivation and thus by which legal rights are affected. For this reason, different penalties were also considered justified. ${ }^{160}$ Thus, instead of making the political motivations and the grievances behind the acts a mitigating factor offering justification to them, the ideology aggravated the crimes. This seems to contrast the global attempts to exclude terrorism from the scope of the POE by concentrating on its material elements instead of the mental element. This 'repoliticisation' of terrorism is discussed in Section 5.3.

Before the creation of the Framework Decision, only six EU member states (France, Germany, Italy, Portugal, Spain, UK) had separately incriminated terrorist acts. Their criminal law definitions, however, varied notably. ${ }^{161}$ The Framework Decision, which was aimed at replacing national definitions, has been seen as a relatively successful attempt to define terrorism in a way that is precise enough from the point of view of legal safety. ${ }^{162}$

Post-2001, the European Council also made an effort to improve its means to battle terrorists within Europe. In 2003, the European Convention on the Suppression of Terrorism from 1977 was amended by a new protocol. ${ }^{163}$ The new convention made all crimes covered by UN antiterrorism conventions and protocols extraditable between European Council member states. Article 13, providing for signatories to make reservations to the provisions of the ECST, had been problematic since its creation. The new protocol notably narrowed the possibility for states to make reservations concerning the POE. ${ }^{164}$ The convention was edited based on the United Nations Security Council Resolution 1373 of 28 September 2001, which "calls upon all States [...] to ensure, in conformity with international law, $[\ldots]$ that claims of political motivation are not recognised as grounds for refusing requests for the extradition of alleged terrorists." 165

The discrimination clause was retained in the 2003 protocol, ${ }^{166}$ for the purpose of "safeguard[ing] the traditional right of asylum." As maintained in the Explanatory Report to the Convention, discrimination by member states of the

160 European Commission, Proposal for a Council Framework Decision on Combating Terrorism, COM (2001) 521 Final, 2001/0217 (CNS), 19 September 2001, 7-8.

161 Dumitriu, 2004, 590.

162 Dumitriu, 2004, 602.

163 Protocol amending the European Convention on the Suppression of Terrorism, European Treaty Series No. 190, 15 May 2003.

164 Article 12, Protocol amending the European Convention on the Suppression of Terrorism, European Treaty Series No. 190, 15 May 2003.

165 Explanatory Report to the European Convention on the Suppression of Terrorism, ETS No. 90, 27 January 1977.

166 Protocol amending the European Convention on the Suppression of Terrorism, European Treaty Series No. 190, 15 May 2003. 
European Council which had ratified the European Convention on Human Rights was "unlikely": "it was considered appropriate to insert this traditional provision $[\ldots]$ in this Convention also, particularly in view of the opening of the Convention to non-member States.]"167

In 2004, the European Arrest Warrant (EAW) was created to replace traditional extradition agreements within the EU. ${ }^{168}$ It aimed at improving and simplifying a variety of judicial procedures; extradition being one of them. Since the 1957 European Convention on Extradition, there had been several attempts to improve collaboration between European states. In 1992, with the creation of the European Union, crime-related matters had been incorporated into the Third Pillar of the Maastricht treaty. One of the aims of this intensified collaboration was to improve the battle against terrorism amongst member states. ${ }^{169}$

The Schengen acquis that abolished internal borders within the contracting states in 1985 had been adopted with compensatory measures, including mutual assistance in criminal matters. As a result, in 1995 and 1996, the EU simplified extradition procedures between member states by replacing the European Convention on Extradition of 1957, the ECST, the Schengen Agreement and the Benelux Treaty with the new convention. ${ }^{170}$ The 1996 convention seemingly abolished the POE between member states. Its Article 5 stated: "1. For the purposes of applying this Convention, no offence may be regarded by the requested Member State as a political offence, as an offence connected with a political offence or an offence inspired by political motives." However, it left this open for reservations. The discrimination clause was also still used in the text of the convention. ${ }^{171}$

The adoption of the treaty was influenced by pressure from Spain to abolish the POE as a follow-up to a foiled extradition request two Spanish nationals, García and Moreno, from Belgium. They were accused of providing logistic support for the ETA. Extradition was denied as the Spanish court concluded that the crimes were not serious enough to constitute terrorist offences under the 1977 treaty. García and Moreno had also requested asylum, but this request was denied. ${ }^{172}$

167 Explanatory Report to the European Convention on the Suppression of Terrorism, ETS No. 90, 27 January 1977.

168 Council Framework Decision of 13 June 2002 on the European arrest warrant and the surrender procedures between Member States - Statements made by certain Member States on the adoption of the Framework Decision, (EAW decision) 2002/584/JHA, OJ L 190, 18 July 2002. See a detailed evaluation of the EAW in Wouters and Naert, 2004.

169 Article Kl, Title IV, Treaty on European Union (Maastricht Treaty), OJ 92/C 191/01, 7 February 1992.

170 Convention, drawn up on the basis of Article K.3 of the Treaty on European Union, on simplified extradition procedure between the Member States of the European Union, Brussels, O.J. 1995, C 78/2, 10 March 1995. See in more detail on European extradition arrangements Eser, Lagodny and Blakesley (eds.), 2002, 100-102.

171 Article 5(3), Convention, drawn up on the basis of Article K.3 of the Treaty on European Union, relating to extradition between the Member States of the European Union, O.J. 1996, C 313/12, 27 September 1996.

172 See Bribosia and Weyembergh, 1997, 71-77; Dugard and Van den Wijngaert, 1998, 201. 
The EAW aimed at improving collaboration and streamlining extradition procedures between EU members, as these were still, regardless of the new conventions, considered lacking in the early 2000s. According to Wouters and Naert, the EAW was created "under great political pressure and its scope largely exceeds the fight against terrorism." ${ }^{173}$ It substituted all bilateral and multilateral European extradition treaties. ${ }^{174}$

The EAW abolished the political offence exception and the dual criminality requirement for a number of serious crimes by making all judicial decisions within the EU mutually recognisable. It introduced a list of 32 offences for which double criminality was no longer required. The only criterium was that the offence had to be punishable with a sentence of a maximum period of at least three years. ${ }^{175}$ In a way, the EAW brought back the list system that had been widely used in extradition treaties from the 1800s until the mid-20th century.

Terrorism is mentioned as the second item in the EAW treaty text, the first being "participation in a criminal organisation." No purely political crimes are as such mentioned, but there is nothing that prevents them from becoming extraditable: "For offences other than those covered by paragraph 2 [the listed 32 offences], surrender may be subject to the condition that the acts for which the European arrest warrant has been issued constitute an offence under the law of the executing Member State, whatever the constituent elements or however it is described." 176

The EAW represents a wider paradigm shift in the legal collaboration between member states. The traditional mistrust between states in each other's judicial decisions had now changed to a high level of confidence among the EU members. ${ }^{177}$ With the EAW, extradition was transformed from a semi-political

173 Wouters and Naert, 2004, 916.

174 European Convention on Extradition, European Treaty Series No. 24, 13 December 1957; Additional Protocol to the European Convention on Extradition, ETS No. 86, 15 October 1975; Second Additional Protocol to the European Convention on Extradition, ETS No. 98, 17 March 1978. Convention, drawn up on the basis of Article K.3 of the Treaty on European Union, on simplified extradition procedure between the Member States of the European Union, Brussels, 10 Mar. 1995, O.J. 1995, C 78/2. Convention, drawn up on the basis of Article K.3 of the Treaty on European Union, relating to extradition between the Member States of the European Union, O.J. 1996, C 313/12, 27 September 1996.

175 However, even if the list of extraditable offences covers a range of serious crimes and the requirement that the offence should be punishable by at least three years limits the acts that are automatically extraditable, there can still be notable differences in member states' judicial systems that come into play. As Sievers (2008) has pointed out, for instance in Ireland abortion is considered a murder, and thus a punishable offence. In many other states this is not true. Sievers, 2008, 111.

176 Article 1(4), EAW decision, 2002/584/JHA, OJ L 190, 18 July 2002.

177 Wouters and Naert, 2004, 920. It is noteworthy that in 2008, the practice of providing asylum to people fleeing a member state was also practically abolished. See Consolidated version of the Treaty on the Functioning of the European Union - Protocol (No 24) on asylum for nationals of Member States of the European Union, Official Journal (OJ) $115 / 24,9$ May 2008. 
decision, where it had been up to each state to decide how the question of the extradition of political offenders was to be treated, to a purely judicial procedure, where all judicial decisions became mutually recognised between member states.

Wouters and Naert, writing in 2004, maintained that the abolishment of the POE between EU members was a welcomed change, as it ended the era of sympathy with politically motivated rebellion. According to them, the rights of justified rebellions still remained protected by other legal mechanisms, such as the European Convention of Human Rights (ECHR). ${ }^{178}$

However, not all have agreed that these mechanisms suffice in protecting the rights of all fugitives. Writing in 2016, Michaël Meysman stated:

Over the course of the past years, it appears the focus has moved from swift prosecution to European cooperation in criminal cases in which (more) attention is given to fundamental and procedural rights. It appears that the cause for this change in attitude is the realisation that the envisioned and presupposed mutual cooperation between member states based on mutual trust is not working as smoothly as initially hoped. [...] The quintessence of the legitimation for the mutual recognition and cooperation between the member states was based on the supposition that all of them endorsed a mutual commitment to the principles of freedom, democracy, and respect for human rights, fundamental freedoms and the rule of law. The collective membership of the member states to the European Convention on Human Rights constituted the main supporting argument in this respect. This legitimisation, however, was dealt a couple of hard blows over the ensuing years. ${ }^{179}$

As Meysman has pointed out, the EAW did not make all political disputes over extradition matters disappear. The Belgian denial of the extradition of an ETA member, Maria Natividad "Jaione" Jauregui Espina, to Spain in 2016 seems to show that the application of a similar provision to the discrimination clause in the preamble of the EAW is a realistic option even between EU member states. ${ }^{180}$ The court deciding the case made reference to a report by the European Committee for the Prevention of Torture and Inhuman Treatment or Punishment (CPT)

178 Wouters and Naert, 2004, 922.

179 Meysman, 2016, 195-196.

180 "Nothing in this Framework Decision may be interpreted as prohibiting refusal to surrender a person for whom a European arrest warrant has been issued when there are reasons to believe, on the basis of objective elements, that the said arrest warrant has been issued for the purpose of prosecuting or punishing a person on the grounds of his or her sex, race, religion, ethnic origin, nationality, language, political opinions or sexual orientation, or that that person's position may be prejudiced for any of these reasons." EAW decision 2002/584/JHA, OJ L 190, 18 July 2002, preamble, recital 12. For instance, the Belgian Court of Cassation interpreted this in the way that only "in a concrete case, it appeared from ample facts that there was a risk of flagrant violation of one or multiple fundamental rights, recourse could be taken to this ground for refusal." See Meysman, 2016, 194. 
of the Council of Europe and refused extradition. ${ }^{181}$ Whether this provision will realistically be applicable in all cases necessary remains unclear. However, denying extradition for the fear that the requested person might not get a fair trial is a difficult foreign policy decision, especially between tightly allied nations. It thus remains to be seen what the status of political offenders will be in the future.

\subsubsection{The POE in modern days}

The political offence exception remains a characteristic of most modern extradition treaties. It seems that no state has made a systematic decision on whether the POE should form part of its new extradition treaties. For instance, in the case of the UK, its extradition treaty with the United Arab Emirates from 2006 does not contain the POE, ${ }^{182}$ but its 2013 treaty with Morocco does. Additionally, the POE in the Morocco treaty is not even limited by the attentat clause. ${ }^{183} \mathrm{~A}$ completely different provision is provided by the 2006 treaty with Algeria, which provides that extradition shall be refused for political offences "with the exception of terrorist offences." 184 The treaty provides a clause that seems like the discrimination clause: “l) Extradition shall be refused if final judgment has been passed in the requested State: e) where the extradition would breach the international principles of human rights and in particular those provided for in the International Covenant on Civil and Political Rights, done at New York on 16 December 1966." 185 Whether or how the POE is limited is never evident based on the nations party to the treaty in question. For instance, the Canada-Sweden extradition treaty of 2000 does not limit the POE at all, ${ }^{186}$ but the Canada-South Africa treaty does. ${ }^{187}$

It is not surprising that the US position with regard to terrorism, which had been changing since the 1980s, got a push after the events of 2001. In addition to legislative and policy changes that had been enacted since the 1980s, the country's need to enhance antiterrorist collaboration became reflected in its

181 See Meysman, 2016.

182 Grounds for refusal of extradition: Article 4, Extradition Treaty between the United Kingdom of Great Britain and Northern Ireland and the United Arab Emirates on Extradition, Treaty Series No. 6 (2008), 6 December 2006.

183 Article 3, Convention on Extradition between the United Kingdom of Great Britain and Northern Ireland and the Kingdom of Morocco, 15 May 2013.

184 Article 4 (1)(f), Convention between the Government of the United Kingdom of Great Britain and Northern Ireland and the Government of the People's Democratic Republic of Algeria on Extradition, Treaty Series No. 15 (2010), 11 July 2006.

185 Article 4, Convention between the Government of the United Kingdom of Great Britain and Northern Ireland and the Government of the People's Democratic Republic of Algeria on Extradition, Treaty Series No. 15 (2010), 11 July 2006.

186 Treaty on Extradition between the Government of Canada and the Government of Sweden, E103414, CTS 2001, No. 28, 15 February 2000.

187 Article 3, Treaty between the Government of Canada and the Government of the Republic of South Africa on Extradition, E103348, CTS 2001, No. 20, 12 November 1999. 
extradition treaties. However, still in modern days, all US extradition treaties still contain the POE, even if limited in different ways. These include the extradition treaty with its close neighbour Canada. ${ }^{188}$

Several US extradition treaties from the mid-1990s until the early 2000s excluded a variety of violent crimes from the protection of the POE. ${ }^{189}$ These treaties did not typically mention the term terrorism, but listed offences that have typically been considered terroristic. For instance, the Committee on Foreign Relations report on the treaty with Lithuania, signed 23 October 2001, specifically mentioned that during the negotiations, the Lithuanian delegation had confirmed that extraditable offences included terrorist offences. ${ }^{190}$ However, the word terrorism was not mentioned in the treaty text. Instead, the treaty listed several offences that are typically linked with terrorism as exceptions to the POE. These included:

(a) murder, manslaughter, malicious wounding, or inflicting grievous bodily harm; (b) an offence involving kidnapping, abduction, or any form of unlawful detention, including the taking of a hostage; [...] (e) placing or using an explosive, incendiary or destructive device capable of endangering life, of causing substantial bodily harm, or of causing substantial property damage; and (f) a conspiracy or attempt to commit any of the foregoing offences, or aiding or abetting a person who commits or attempts to commit such offences.

Similar or identical provisions were also included in the US-Latvia 2005, USIsrael 2005, US-Estonia 2006 and US-Romania 2007 treaties. ${ }^{191}$ Thus, even if these treaties still contain the political offence exemption, it is practically limited to cover only pure political crimes.

188 Article 4(1)(iii), Treaty on Extradition between the Government of Canada and the Government of the United States of America, 3 December 1971.

189 See e.g. Article 4, Extradition Treaty between the Government of the United States of America and the Government of the Republic of South Africa (with annex), 16 September 1999; Poland International Extradition Treaty with the United States, 10 July 1996; Extradition Treaty between the United States of America and the Grand Duchy of Luxembourg, 1 January 1996; Extradition Treaty between the Government of the United Kingdom of Great Britain and Northern Ireland and the Government of the United States of America, 31 March 2003.

190 107th Congress, 2nd Session, Executive report, Committee on Foreign Relations, 107-13, 21 October 2002.

191 Latvia International Extradition Treaty with the United States, 7 December 2005; Article 4, Protocol between the Government of the State of Israel and Government of the United States amending the Convention on extradition signed at Washington D.C. on December 10, 1962, 6 July 2005; Article 4, Extradition Treaty between the Government of the Republic of Estonia and the Government of the United States of America, 8 February 2006; Article 4, Romania International Extradition Treaty with the United States, 10 September 2007. 
It is noteworthy, that all of the aforementioned treaties excluded causing property damage from the POE, a provision rarely used in US treaties. ${ }^{192}$ C.A.J. Coady has argued that destruction of non-combatant property justifiably is often interpreted as terrorist, as such property is not considered as a legitimate target. ${ }^{193}$ However, the US treaties which mention property damage do not limit the damage to non-legitimate targets or non-combatant property. The idea of 'causing substantial property damage' is very encompassing. As the scope of excluded offences in these treaties is very wide, they essentially rule out all forms of relative political crimes from the scope of the POE.

These treaties, like most treaties since the mid-1980s, included the possibility to deny extradition, should the executive authority of the requested state consider the request politically motivated. ${ }^{194}$ However, between states such as Estonia and the United States, allies and members of the North Atlantic Treaty Organization (NATO), it seems unlikely that this option would ever be used.

In 2003, the United States and the United Kingdom renewed their extradition treaty dating from 1972, including the Supplementary Treaty of 1985. The 2003 treaty contained most of the same limitations to the POE set already in 1985. However, in the letter of submittal, the terrorist threat received an important role:

The United Kingdom is a key law enforcement and counterterrorism partner of the United States. Recent events, including the foiling of a terrorist plot targeting civil aircraft scheduled to fly between the United Kingdom and the United States, have underscored the importance of this relationship.

According to the new treaty provisions, extradition could not be denied when the fugitive had committed a crime that the requested party had an obligation to either prosecute or extradite (aut dedere aut judicare). Additionally, against British tradition, the attentat clause was reintroduced, covering both heads of states, as well as their family members of the two parties of the treaty. The list of crimes that could not be protected by the POE otherwise remained the same, except for provision (f) "possession of an explosive, incendiary, or destructive device capable of endangering life, of causing grievous bodily harm" had the addition of "or of causing substantial property damage" and provision $(\mathrm{g})$ concerning the aiding and abetting to the mentioned crimes that now included a conspiracy to commit, as well as the "counselling or procuring the commission of, or being

192 See also Article 5, Poland International Extradition Treaty with the United States, 10 July 1996; Article 4, Treaty between the Government of the United States of America and the Government of the Republic of Hungary on Extradition, 18 March 1997; and Article 4, Bulgaria International Extradition Treaty with the United States, 19 September 2007.

193 Coady, 2008, 160.

194 See e.g. Article 4, Extradition Treaty between the United States of America and Lithuania, 23 October 2001; Article 4, Estonia International Extradition Treaty with the United States, 8 February 2006. 
an accessory before or after the fact to any of the foregoing offences." 195 Thus the provisions that relate to terrorist tactics were growingly excluded from the scope of the exception. However, the concept of terrorism was still not mentioned in the treaty text itself. The possibility to turn down the extradition request, should it be politically motivated, was preserved. In the US, the decision was now done by the Secretary of State.

There were concerns that the treaty was created to provide for the extradition of individuals who had taken part in the conflict over Northern Ireland prior to the Belfast or Good Friday Agreement of April 1998. The Belfast Agreement was linked to an early release for those convicted of offences relating to terrorism before the signing of the agreement. Nonetheless, the United States Committee on Foreign Relations underscored that the aim of the 2003 treaty was to modernise the extradition process between the UK and the US and strengthen law enforcement collaboration for serious offences; it was "not intended to reopen issues addressed in the Belfast Agreement or to impede any further efforts to resolve the conflict in Northern Ireland."196

In July 2003, an extradition agreement between the European Union and the United States was signed. The role of the treaty was partly to replace existing extradition treaty provisions and partly to include new provisions. Its aim was to improve and enhance coordination and collaboration between the parties. However, previous and new bilateral treaties between the US and each EU member state were still valid. For instance, parties to the treaty could still invoke existing grounds of refusal to the new provisions. ${ }^{197}$

The 2003 agreement between the EU and the US made no mention of the political offence exemption. It required double criminality, meaning that the offence the fugitive was sought for needed to be a punishable crime under the laws of both nations and that the punishment for the crime would in both countries be a maximum period of more than one year or a more severe penalty. The treaty also covered the attempt or conspiracy to commit, or participation in the commission of, an extraditable offence. ${ }^{198}$ It seems that without the contents of bilateral treaties, the treaty would have abolished the political offence exemption. However, solely based on this agreement it cannot be deduced that all protection for political offenders between the US and the EU would have ceased, as such protection is still used in bilateral extradition treaties.

195 Article 4 of the Extradition Treaty Between the Government of the United Kingdom of Great Britain and Northern Ireland and the Government of the United States of America, 31 March 2003.

196 The Committee on Foreign Relations Recommendation and Comments regarding the Extradition Treaty between the Government of the United Kingdom of Great Britain and Northern Ireland and the Government of the United States of America, 20 September2006.

197 Article 3, Agreement on Extradition between the European Union and the United States of America Official Journal (OJ) L 181/27, 19 July 2003. See Wouters and Naert, 2004, for a detailed discussion on the agreement.

198 Article 4, Agreement on Extradition between the European Union and the United States of America, Official Journal (OJ) L 181/27, 19 July 2003. 


\subsubsection{Applying the POE in the 2000s}

The POE, even if severely limited, still remains problematic for the US and its foreign policy. To illustrate this, a few recent cases concerning the extradition of wanted terrorists are presented. In addition, I will point out that other forms of political crimes are alive and well, and open a discussion of the cases of Julian Assange, Chelsea Manning and Edward Snowden. The aim is not to give a thorough analysis on these recent developments but to indicate some particular cases.

In 2005, the US was faced with an extradition request that concerned a Cuban national, Luis Posada Carriles. Posada was wanted by Cuba, as he had been fighting a battle to overthrow Fidel Castro. Posada was a prime suspect in the 1976 bombing of a Cuban commercial airliner, killing 73 people. In a New York Times article, he took responsibility for attacks in Havana, killing an Italian tourist in 1997. Later he renounced the confession. ${ }^{199}$

Posada was convicted in 2000 in Panama for a bomb plot against Fidel Castro. In 2005, he appeared in Florida, seeking political asylum for having served as a Cold War soldier on the payroll of the Central Intelligence Agency in the 1960s. Soon, he was sought for extradition by the Venezuelan government for the Cuban airline bombing. In 2005, the New York Times stated that "Mr. Posada's case could create tension between the politics of the global war on terrorism and the ghosts of the cold war on Communism." As the then-in-power Bush administration had sworn its dedication to the global fight against terrorism, not granting extradition of a wanted terrorist would have been difficult. Then again, to extradite an anti-Castro figure would have caused domestic disputes, especially within the Cuban exile community in Florida, from which the administration received an important amount of support and where the president's brother served as governor. To extradite or to try Posada would have offered an important amount of good publicity for Castro, who had called Posada the worst terrorist in the Western hemisphere. Additionally, Venezuelan President Chavez was no ally to the United States.

Several people took Posada's side in the media, suggesting that the US government should offer him protection. The government had been faced with a similar dilemma before, in the case of Orlando Bosch, who had also been a part of the violent anti-Castro movement. The Justice Department had called Bosch "a terrorist, unfettered by laws or human decency, threatening and inflicting violence without regard to the identity of his victims," in the words of Joe D. Whitley, then an associate US attorney general. However, the first Bush administration decided to overrule the return of Bosch, who stayed in the US. ${ }^{200}$

Finally, both Cuban and Venezuelan extradition requests for Posada were refused by the US, as the US claimed Posada would not receive a fair trial in either country. This resulted in both countries accusing the United States of being hypocritical, as it sheltered a known terrorist while claiming to fight a war 
on terror. ${ }^{201}$ The US later charged Posada with some relatively minor immigration-related offences and his role in the bombings in Havana. He was swiftly acquitted on all charges. The Venezuelan response was that the trial had been 'theatre' and that the US had granted protection to a mass murderer. ${ }^{202}$

Another relatively recent case concerning the application of the POE was that of the Honduran Carlos Yacaman Meza, who allegedly killed Luis Rolando Valenzuela Ulloa, a former member of the Honduran presidential cabinet following a military coup d'état in 2010. The District Court rejected the petition of Meza when he requested the denial of the extradition. The most important factor in making the decision was the fact that the crime was committed only when the political insurgency had cooled off in Honduras. ${ }^{203}$

Christina Piemonte argued in 2013 that there appeared to be a growing trend in the US of excluding relative political offences from the scope of the POE. These include the extortion of a political figure and financial crimes including embezzlement by a public officer, as well as murder and conspiracy. One reason behind this change in court practice could have been the need to promote more friendly relations and reciprocity with foreign countries. However, there is still no clear standard considering which crimes fall within the scope of protection and which do not. Consistent court practice on the matter is yet to emerge. ${ }^{204}$

When applying the political incidence test, the courts are put between a rock and a hard place: remaining neutral towards the most abhorrent crimes and possibly protecting the people that commit them. In the case of Meza, the court followed the logic set in Quinn with regard to the requirement of the political incidence. According to Piemonte, the Quinn decision can prevent the courts from considering the subjective element of the crime. However, the court also made note that Meza's motivation was, instead of politics, his personal anger towards Valenzuela. Further, even if Meza indeed had political motivations, they would not have sufficed to characterise the crime as political.

According to Piemonte, the motives of the offenders are considered where the court sees fit to do so. This happens regardless of the requirement that these should be left out of the scope of consideration, "even setting aside international law," as well as the current situation in the US, committed to law and precedent. However, there seems to be a trend of moving away from the Quinn test towards a test that would also take into account the motives of the crime. The incidence test has proved to be unpredictable in its application. ${ }^{205}$

201 See also Resolución No. 8, Extradición de Luis Posada Carriles XXIII Asamblea Ordinaria del Parlamento Latinoamericano Ciudad de Panamá, República de Panamá, 6-7 December 2007.

202 Carroll, 2011.

203 Meza v. U.S. Att'y Gen., 693 E3d 1350, 1353 (11th Cir. 2012). See in detail Piemonte, 2013, 617-633.

204 Piemonte, 2013, 630.

205 Piemonte, 2013, 631-633. 
The importance of the POE is still highly visible in current days. More recently, very high-profile cases that have at least partially concerned the application of the POE have been those of known whistle-blowers Assange, Manning and Snowden.

It is the political offence exception to extradition that has kept Julian Assange, the founder and director of WikiLeaks wanted by the US for leaking diplomatic and military communications, hiding in the Ecuadorian embassy. ${ }^{206}$ The USEcuador extradition treaty dates from 1872 and contains the classical form of the POE: "The stipulations of this treaty shall not be applicable to crimes or offences of a political character." 207

Otto Kirchheimer wrote in 1961:

As an essential factor in extradition cases, the governmental machine's striving for self-preservation and survival may not be as tangible as considerations of foreign policy strategy. In countries with unstable governmental system given to frequent revolutionary removal of rulers, physical survival often hinges on strong asylum safeguards reinforced by an iron-clad rule of non-extradition for political offences. Reciprocal recognition of such protective services, which saves lives in revolutions, junta uprisings, and other instances of government selection through bloodshed have established a kind of supranational cartel of the ruling elite. The tacit understanding that unites South America's regimes is an illustration. Non-extradition for political offences is supplemented by 'diplomatic asylum'. Instead of escaping across the border, endangered individuals seek refuge behind the walls of a foreign embassy, extraterritorial on the national territory, and the regime from which they escape respects the sanctity of such refuge and even provides safe-conduct provisions for those willing to leave the protection of diplomatic immunity in the homeland and go abroad. Too frequent use of this device has been vehemently attacked. It obviously handicaps the ferreting out of political offenders, as it ensures their safety too close to the locale of their rebellious activities. ${ }^{208}$

Regardless of the non-violent character of the leaks, Fox News, known for its sympathies for the US Republican Party, has called WikiLeaks a terrorist organisation. It wrote in 2010:

WikiLeaks founder Julian Assange isn't some well-meaning, anti-war protestor leaking documents in hopes of ending an unpopular war. He's waging cyberwar on the United States and the global world order. Mr. Assange and his fellow hackers are terrorists and should be prosecuted as such. ${ }^{209}$

206 See e.g. Newsweek, 29 March 2017, "Will Julian Assange be sent to the U.S.? Ecuador election results could decide extradition case."

207 Ecuador International Extradition Treaty with the United States, 28 June 1872.

208 Kirchheimer, 1961, 372.

209 Fox News, 30 November 2010, "Yes, WikiLeaks is a terrorist organization and the time to act is NOW." 
It is telling that a criminal whose deeds ${ }^{210}$ are clearly and purely political, no matter how they are judged, ${ }^{211}$ is called a terrorist by one of the main news channels in the US.

The case of Edward Snowden, former employee of the National Security Agency (NSA) who leaked US intelligence documents, is also interesting. ${ }^{212}$ Snowden resides in Russia, a country with no current extradition treaty with the US. ${ }^{213}$ According to a document written by the Swiss prosecutor's office, "Edward Snowden could be assured of free movement by the federal prosecutor if he cooperated with a criminal investigation" into US spy activities he says he learned about while working in Geneva. In this hypothetical scenario, extradition to the US would not be granted due to the political nature of the crime. ${ }^{214}$ The US-Swiss extradition treaty of 1990 contains the POE, limited by the multilateral treaty clause. ${ }^{215}$ Thus the nature of Snowden's crimes would allow for his protection under the treaty clauses.

These recent cases, including the case of Chelsea Manning, who is accused of leaking hundreds of thousands of US classified documents, ${ }^{216}$ demonstrate that political criminals whose actions can be judged in different ways still exist, even within Western states.

\subsection{5 "Ballot rather than the bomb": ${ }^{217}$ fixing the POE}

Due to its problematic nature, the political offence exemption has been a subject of scholarly dispute. Many writers have, since the end of the Second World War, been trying to come up with solutions to problems that relate to the application of the POE. According to some, the POE protects too many categories of fugitives, has been outdated for decades, and needs to be annihilated or at least limited. The wishes to dismantle the POE have been connected to, at least in part, the intensified fight against terrorism, sometimes impeded by the application of the POE.

According to some, the POE is not necessary for the protection of political offenders from unfair and retaliatory trials. Additionally, it is problematic because,

210 Notwithstanding accusations of rape in Sweden unrelated to his work as the founder of WikiLeaks.

211 There is a growing amount of information regarding the role of Julian Assange in meddling in with the US election. Without a value judgement, these are still non-violent, political acts. See e.g. The Washington Post, 27 September 2018, "The image of Julian Assange grows darker by the day," for more information on the most recent developments in the Assange case.

212 See e.g. The Guardian, 21 August 2013, "Edward Snowden and the NSA files - timeline."

213 See e.g. New York Times, 18 January 2017, "Russia extends Edward Snowden's asylum."

214 Reuters, 15 September 2014, "Switzerland would shield Snowden from 'political' extradition to US."

215 Article 3, Extradition Treaty between the Government of the United States of America and the Government of the Swiss Confederation, 14 November 1990.

216 New York Times Magazine, 12 June 2017, “The long, lonely road of Chelsea Manning."

217 Petersen, 1992, 791. 
without the invocation of the aut dedere aut judicare principle, ${ }^{218}$ it protects the fugitive from all judicial consequences. ${ }^{219}$ As such, the denial of extradition disrupts world public order, because it causes turmoil in relations between states and allows states not to prosecute offenders regardless of their existing duty to do so. ${ }^{220}$

Many would contend that in liberal democracies that guarantee individual rights, violence is no longer a legitimate tool to promote political reform. As such, the wish to eliminate the POE is linked to a wider ideological change, maintaining there is no longer a justification for the use of political violence to create political change. ${ }^{21}$ According to Antje Petersen: "A traditional political offence exception contradicts the international, nonviolent approach by sanctioning violence as a means to bring about political change." The complete annihilation of the POE seems to necessitate the idea that there is no longer a need or justification for extralegal or illegal political dissidence. As Petersen put it, "At the end of our century, this attitude has dramatically changed in the community of democratic nations who believe in political change through the ballot rather than the bomb." 222 In the context of the European Union, the shared values and political structures seem to be considered enough for the 'no questions asked' policy in extradition.

The role of the POE in the US context has been challenged because of the lack of logic in protecting foreign offenders attacking even democracies while the country never offered such protection to any domestic political criminals. Epps, for instance, was in 1988 supportive of the elimination of the POE, provided that the US only entered extradition treaties "with countries with whom it was politically aligned and whose judicial systems were roughly equivalent in terms of the protections offered criminal defendants." 223 A similar choice had been made by the Soviet Communist bloc countries. ${ }^{224}$ Two years earlier, Bradley G. Kulman had also suggested that democratic nations worried about

218 Even the aut dedere aut judicare principle is not without problems. Its application would necessitate universal jurisdiction for politically or ideologically motivated crimes. See in more detail Gilbert, 1998, 320-329; and Sambei, Du Plessis and Polaine, 2009, 422. See Blakesley, 2007, 126-140, for a discussion on the universal jurisdiction of terrorist crimes.

219 Kulman, 1986, 770.

220 Bassiouni, 1969, 234

221 Gilbert, 1991, 139.

222 Petersen, 1992, 791.

223 Epps, 1988, 215. See also Epps, 1979, 87.

224 Epps, 1988, 215; Epps, 1979, 85. See also Epps, 1988, 206:In earlier eras the exception [POE] made some sense. Any attempt to topple a foreign and therefore unenlightened, government might be welcomed as striking a blow for freedom [...]. But today when countries perceive themselves aligned in major political blocs, it hardly makes sense to retain the exception in treaties with states who share a fundamentally similar political outlook and have broadly similar governmental structures. This point is even more emphatic when it is recognised that generally countries only enter into extradition treaties with those countries with whom they maintain more or less cordial relations. The United States, for example, has no extradition treaties with Soviet bloc countries. 
unfair trials could only draw extradition treaties with democracies with strong independent judiciaries. ${ }^{225}$

Epps further argued that the POE was not required even if there was a need to enter into an extradition treaty with a non-aligned state for the purposes of international travel. For her, the short notice termination provision typically used in extradition treaties represented a sufficient safeguard for the rights of the fugitive. Additionally, the Secretary of State, overviewed by the American public, had a review mechanism of courts' extradition decisions that could be used to evaluate the political justification of the fugitive's actions. ${ }^{226}$

Today the idea of entering extradition treaties only with democratic allies seems impossible. Even if it were a viable alternative, it has rightfully been pointed out that there are no guarantees that a once-democratic ally could not one day become a non-democratic state or a non-ally. ${ }^{227}$ Political conditions are bound to change. Regardless of the short termination provisions, extradition treaties are in practice not renewed often. This means that the process of trying to renegotiate a treaty based on an evaluation of the other party's domestic policies can prove diplomatically impossible. Further, as discussed, denying the extradition of a political offender on the basis that their cause is justified is no easy foreign policy decision. Exterminating a whole extradition treaty for the protection of one offender is definitely not a more sensitive foreign policy decision.

A less radical option in safeguarding the original purposes of the POE and restricting its application with regard to terrorist crimes is limiting the POE itself. This has been suggested by John Norton Moore, who supported the exclusion of all violent crimes from the exception "in extradition treaties with the principal democracies in the world." 228 Similarly, for instance, Gilbert has suggested that the exemption should not be used to protect those who wish to replace an elected government dedicated to the protection of human rights and fundamental freedoms, where other political remedies instead of the use of violence are available. ${ }^{229}$ For this reason, he argued that a partial or regional restriction of the POE could be acceptable within Western industrialised nations, adhering to liberal democratic principles and the ECHR. ${ }^{230}$ Such a method has been applied for instance in the US-UK relations, as discussed earlier.

Gilbert has also noted the many problems relating to this approach. Such limitations would require set criteria of 'stable democracy' and of 'political crime.' Additionally, regime changes would complicate the situation. ${ }^{231}$ Having different policies with regard to the POE with different states might also create safe havens for terrorists by alienating those states that are excluded from joining such

225 Kulman, 1986, 773.

226 Epps, 1988, 216.

227 Blakesley, 1986, 122; Lampo, 1988, 249; Gilbert, 1998, 270; Gilbert, 1991, 140.

228 Norton Moore, 1988, 442.

229 Gilbert, 1991, 135.

230 Gilbert, 1998, 269.

231 Gilbert, 1998, 270. 
treaties. Additionally, it can be seen as a reactionary move, diminishing the credibility of the fight against terrorism diminish. ${ }^{232}$

In practice, the US has never restricted the signing of extradition treaties to democracies. Extradition treaties were commonly used as gestures of friendship, for instance with newly established regimes in the early 20th century. Further, even when parliamentary regimes were overthrown and replaced by dictatorships, extradition treaties were not abrogated or suspended. According to Christopher H. Pyle, this related to diplomats' and administrators' valuing order over liberty. ${ }^{233}$ Once these treaties were signed, due to the rule of non-inquiry, the courts did not take a stand on whether the requesting regime had a fair judicial system. It was typically assumed that if the US had an extradition treaty with the requesting state, the system had to be fair. ${ }^{234}$

During the last decades, there has been a complete turnaround in the way in which the American public perceives political offenders. Whereas before, it was considered that political offenders from the old world crossing the Atlantic escaped despotic governments and took their chance to reinvent themselves in the new world would cause no trouble upon arrival. Furthermore, as the US initially did not really have a government to rebel against, these former criminals seemed less threatening. In contrast, since the Second World War, most political fugitives have not been considered trustworthy, and nowadays they are often perceived as terrorists. Non-Communist governments have been assumed to be democratic, especially if they refer to themselves as such and their legitimacy of has typically not been questioned. ${ }^{235}$

As a way to fix the POE, Pyle has suggested that different legal systems could be given an accreditation based on assessments provided by NGOs and human rights groups. These groups would evaluate whether the fugitive would receive unfair treatment upon their return. Should a requesting nation deny this evaluation, it would be placed in an 'unaccredited regimes' list. ${ }^{236}$ This would mean ending the rule of non-inquiry of US courts. ${ }^{237}$

However, even in a country with a fair judicial system, it is possible for political offenders to be punished for their motives. Further, as it is for the state of asylum to decide whether the fugitive would receive fair treatment upon their return, the fugitive's rights remain dependent on the way in which the asylum state understands the concept of procedural fairness. Additionally, denying extradition based on the unfairness of the requesting state's judicial system, especially between friendly nations, is a diplomatically very difficult decision, as it represents an overt condemnation. ${ }^{238}$ 'Fair trial' is a vague concept even if its requirements are determined in Article 6 of the ECHR. Further, these rights are not of assistance in a

232 Gilbert, 1991, 139; Gilbert, 1998, 269.

233 Pyle, 2001, 126, 319.

234 Pyle, 2001, 128.

235 Pyle, 2001, 130; 302.

236 Pyle, 2001, 315.

237 Pyle, 2001, 321.

238 Gilbert, 1991, 154; Gilbert, 1998, 311. 
terrorist case, where the suspect can be denied access to a regular court based on national security concerns. For this reason, Gilbert has argued that the abolishing of the POE and replacing it with a fair trial requirement does not function when the offenders have intended to challenge the authority of the same state that is organising the trial. ${ }^{239}$ Further, applying a test to determine whether the offender can receive a fair trial can create antagonism, which can result in discouraging international collaboration. ${ }^{240}$

Then again, the non-surrender of political offenders is equally biased vis-à-vis another state's internal issues as granting every request would be. In fact, the nonextradition of a suspect is a highly political decision. ${ }^{241}$ The discrimination clause could serve the purpose of protecting those who might end up being discriminated based on their beliefs or personal qualities, ${ }^{242}$ but its application is even less neutral than that of the POE. The application of the POE can be used to provide a 'legal cloak' to a political judgment and it allows for the political decision-makers to evade diplomatic collision. ${ }^{243}$ Thus the application of the POE is, paradoxically, also a way to depoliticise the political nature of an extradition decision.

The denial of extradition of a political offender gives support for the political adversary of the requesting state. As Van den Wijngaert has maintained, this practice is highly illogical between allied states which have agreed upon protecting each other with regard to an external threat, but by invoking the POE would offer protection to those trying to disrupt this safety. ${ }^{244}$ Likewise, Epps argued in 1988 that the POE was "strangely contradictory when it forbids extradition from the United States of the fugitive Briton who blows up the Houses of Parliament in an attempt to replace Mrs Thatcher with a Communist regime."245

One suggested 'fix' for the POE would be to limit its application to cases where the fugitive would also be eligible for asylum, ${ }^{246}$ as states still hold the right to decide upon providing asylum to those persecuted for political beliefs. ${ }^{247}$ Such a take has been advocated by a number of judges. ${ }^{248}$ This would essentially mean introducing the application of the proportionality test. The criteria provided by the UNHCR Handbook and Guidelines on Procedures and Criteria for Determining Refugee Status define a comparable evaluation to the Swiss test:

In determining whether an offence is 'non-political' or is, on the contrary, a 'political' crime, regard should be given in the first place to its nature and purpose, i.e. whether it has been committed out of genuine political motives

239 Gilbert, 1998, 309-315.

240 Gilbert, 1998, 311.

241 Sapiro, 1986, 663-664; Van den Wijngaert, 1980, 204-205.

242 However, the discrimination clause is so general in nature that for instance the US Congress did not pass it as legislation. Gilbert, 1991, 144.

243 Lieberman, 2007, 190.

244 Van den Wijngaert, 1980, 204-205.

245 Epps, 1988, 206.

246 Gilbert, 1991, 137, 150.

247 Hannay, 1980, 411; Epps, 1988, 215; Petersen, 1992, 791.

248 Gilbert, 1998, 431. 
and not merely for personal reasons or gain. There should also be a close and direct causal link between the crime committed and its alleged political purpose and object. The political element of the offence should also outweigh its common-law character. This would not be the case if the acts committed are grossly out of proportion to the alleged objective. The political nature of the offence is also more difficult to accept if it involves acts of an atrocious nature. 249

According to Gilbert, a combination of adopting the proportionality test, the safeguarding of the discrimination clause and the application of the aut dedere aut judicare principle to all politically or ideologically motivated offenders, with the exclusion of all crimes covered by UN multilateral conventions would serve all the original purposes of the POE. Using such methods would maintain international public order, bring fugitives to justice and safeguard human rights. ${ }^{250}$ Christopher H. Pyle, in turn, has been supportive of the 'wanton crimes' approach applied by some US courts. According to him, it is important to leave the judges enough "wiggle room" to "do the right thing." ${ }^{251}$ In order to find the appropriate balance between order and liberty, Pyle has suggested that the use of the criteria of the wanton crimes approach would provide the courts with the means to evaluate the nature of the crime against the nature of the regime attacked. ${ }^{252}$ There are many similarities between the proportionality test and the wanton crimes approach. Neither is a one-size-fits-all solution but both seem to lead to similar conclusions regarding who is worthy of the protection of the POE and who is not.

Some attempts to limit the POE in multilateral treaties and conventions have been successful. Limitations concerning war criminals and the drafting of the Genocide Convention have, for instance, been widely accepted. Furthermore, typical extradition treaties now contain the multilateral treaty clause. ${ }^{253}$ However, as discussed, this process is far from finalised. There is no agreement upon what kind of conduct would automatically be exempted from the scope of the POE. ${ }^{254}$ For instance, Cindy Schlaefer has called upon a treaty defining those acts of

249 Para 152, Handbook on Procedures and Criteria for Determining Refugee Status under the 1951 Convention and the 1967 Protocol velating to the Status of Refugees, HCR/IP/4/Eng/ REV.1 UNHCR 1979, reedited January 1992. Italics added.

250 Gilbert, 1991, 162. The predominance test has also been supported by e.g. Van den Wijngaert, 1980; and Perry, 1989, 734.

251 Pyle, 2001, 195.

252 Pyle, 2001, 315-317.

253 See e.g. Costa Rica International Extradition Treaty with the United States, 4 December 1982; Jamaica International Extradition Treaty with the United States, 14 June 1983; Extradition Treaty between the Government of the United States of America and the Government of the Republic of South Africa (with Annex), 16 September 1999; Extradition Treaty between the Government of the United Kingdom of Great Britain and Northern Ireland and the Government of the United States of America, 31 March 2003.

254 Tulkens, 1979, 231; Norton Moore, 1988, 442; Cassese, 1989, 11; Lieberman, 2007, 212. 
terrorism which would always be subject to extradition regardless of their political motivations. ${ }^{255}$ Also, Gilbert has been supportive of the use of the "positive approach," which allows for judicial discretion. ${ }^{256}$ Françoise Tulkens, writing in 1979, suggested the depoliticisation of certain offences. ${ }^{257}$ As established, this has been the most common global approach, used by for instance the UN. However, specified multilateral treaties are partly problematic as it is impossible to predict all future cases where the POE might be invoked. ${ }^{258}$

Scholars have also suggested that acts in peacetime against civilians that are against the laws of war by analogy should be excluded from the scope of the protection. This would protect legitimate dissidents. However, the direct application of the laws of war could prove difficult, as their provisions are limited to noninternational armed conflicts. ${ }^{259}$ Most acts of international terrorism would most likely not fall under the scope of this definition.

The problem with the exclusion of terrorism from the scope of political offences is akin to the problem of trying to create an antiterrorist resolution. For instance, John Patrick Groarke has been of the opinion that with a global definition of a political offence, it would be possible to exclude those that have attacked civilians from the protection of the POE, meaning that the most "offensive type of terrorist acts" would not go unpunished. ${ }^{260}$ A similar stance was taken by the courts in the Eain and Quinn cases.

However, the definition of 'civilian' has in itself always proved problematic. For example, is violence against the police forces of a state legitimate?261 In Antje Petersen's words: "uncertainty clashes with uncertainty when terrorism has to be located on a scale of acceptable political struggle in the context of deciding on protection from extradition." 262 In my view, considering, for instance, police officers or soldiers patrolling the streets of a major city 'civilians' would not be an accurate description. These people are and should be protected by different laws that ordinary citizens. For this reason, acting against them could be seen as a political act. Whether such an act is legitimate is a separate question.

What does it mean if due to the terrorist threat, the political offence exception is eliminated on a global scale? The purpose of the POE was never to protect terrorists. However, the wider trend of excluding all violent crimes from the scope of the POE seems to be against its original purposes. The justification for the use of violence for political ends is disputable, but it is always possible to consider some revolutions

255 Schaefer, 1981, 643

256 Gilbert, 1991, 148.

257 Tulkens, 1979, 231.

258 Lieberman, 2007, 205.

259 Epps, 1988, 211.

260 Groarke considers acts against police officers and soldiers as acts against the state. Groarke, $1988,1543$.

261 Lubet, 1982, 272.

262 Petersen, 1992, 788. 
legitimate. ${ }^{263}$ For instance, Bassiouni has considered the use of the POE vital in situations where the fugitive lacked lawful means of redress or remedy. However, the denial of extradition could be subject to limitations relating to the violation of rights and the means of redress chosen by the individual in question. ${ }^{264}$ Bassiouni wrote in 1969: "This theory of ideological self-preservation is not advanced as a means to warrant or justify lawlessness, or anarchy, but is intended to relate an otherwise nebulous concept, which has been the subject of nefarious political manipulations, to the sphere of a legally or judicially manageable theory of law." 265

As maintained by Christopher H. Pyle: "It is nonsense to say that the political offence exception is no longer needed because yesterday's freedom fighters have been replaced by today's 'terrorists'. However, it is equally important to recognise that the exception should not be used to shield a person who indiscriminately kills and maims innocent people."266

In general, states tend to consider that killing can sometimes be permissible for the furtherance of a political goal. For this reason, they do not want to entirely ban this option but wish to control who uses this method and against whom. Some states have, however, previously excluded crimes of special cruelty from the scope of protection of the POE in their national laws. ${ }^{267}$

In 1970, Martin E. Gold estimated that as ideological differences between nations would increase, so would the practice of granting political asylum. ${ }^{268}$ In the West, it seems that the opposite has happened. Is the eradication of the exception, then, a logical development arising from the so-called 'end of history,' the victory of liberal capitalism from all other political systems? ${ }^{269}$ Hardly. The elimination of the POE does not seem to reflect the rise of mutual trust even if some have made this argument. ${ }^{270}$ Instead, it can be seen to express an end of an optimist phase of liberalism, where political change was still seen capable of making the world better, not worse. For this reason, it manifests the end of the era of a romantic view towards political offenders more than anything else.

Scholars have been concerned with the possible implications of the complete evisceration of the POE. For instance, Ivor and Clive Stanbrook stated in 2000: "There is now a danger that detestation of political violence may lead governments to depoliticise so many offences, leaving no scope for the political offence exception or for political asylum at all. That would be a tragedy for human liberty." ${ }^{271}$ Ben Saul

263 Petersen, 1992, 791.

264 Bassiouni, 1969, 256.

265 Bassiouni, 1969, 257.

266 Pyle, 2001, 315.

267 See e.g. Article 5(2), France: Loi du 10 mars 1927; Loi relative à l'extradition des étrangers, 10 March 1927. Extradition would not be allowed if the crime was of political character or the criminal was wanted for a political purpose. Acts committed during an insurrection or civil war could only be extraditable after the war had terminated and only in case they constituted acts of "barbarie odieuse et de vandalisme défendus" according to the laws of war.

268 Gold, 1970, 211.

269 See Fukuyama, 1992.

270 Boister, 2002, 203.

271 Stanbrook and Stanbrook, 2000, vi. See also Stanbrook and Stanbrook, 2000, 87. 
has been concerned about the status of those resisting oppressive governments by means of discriminate and proportionate violence. ${ }^{272}$ Similarly, Christopher H. Pyle has underlined the possible unwanted consequences of the exclusion of all violent crimes from protection. "It loads the law of extradition wholly against revolutionaries and wholly in favour of established regimes, whose indiscriminate killing can always be characterised as law enforcement and who, with their superior firepower and organisation, are most likely to prevail." ${ }^{273}$ Geoffrey Gilbert, after a thorough discussion about the acceptability of violence in a democracy, concluded that even in a so-called stable democracy, there can be room for justified violence. For this reason, the POE forms a necessary feature of extradition treaties. ${ }^{274}$ Christopher L. Blakesley has pointed out that the evisceration of the POE is not a desired or even efficient means of fighting terrorism. ${ }^{275}$

Philosopher C.A.J. Coady has also maintained that it is not possible to definitively argue that violence in a democratic society would never be acceptable.

It may be said that a moral case for revolution against a dictatorship can exist, but never against a democracy. As a convinced democrat, I am sensitive to the force of this rejoinder but find its force blunted by two considerations. The first is that many basically non-democratic political societies have democratic trappings. The second is that ever since Tocqueville, political theorists have been aware of the problems posed by majority tyranny over minorities and by the deep and serious injustices that democratic legal machinery can countenance - the historic background to the struggle in Northern Ireland is not irrelevant here. In any event, a good deal of revolutionary activity has taken place in countries, like several of those in South America in the notso-distant past, which made small pretence of being democratic, or whose democratic practices tolerated extensive human rights abuses. ${ }^{276}$

Instead of restricting extradition treaties or the scope of the POE itself, alternative means have been suggested for the protection of the principle. Bassiouni has, for instance, suggested an international definition of a political offence or, alternatively, the application of the aut dedere aut judicare principle to all political crimes, potentially using the laws of the jurisdiction against which the accused committed the alleged offence. However, the ideal for Bassiouni was that the offender could be tried in an international court and imprisoned in an international institution. ${ }^{277}$

Many scholars have agreed that the jurisdiction over political crimes could be partly or completely given to an international court capable of judging the

272 Saul, 2015, 402.

273 Pyle, 1988, 201.

274 Gilbert, 1998, 270-279.

275 Blakesley, 1986.

276 Coady, 2008, 168.

277 Bassiouni, 1969, 257-259. See also Allan, 1993, 332 
acts merely on the common element and not on their political motives. ${ }^{278}$ This seems like a plausible option but would potentially necessitate the international definition of concepts such as political crime or terrorism, which have, previously, eluded such attempts.

It is interesting to note that the idea of an international court was brought up at the 1937 League of Nations Conference where the Suppression of Terrorism Convention was signed. In addition to the main Convention, a Supplementary Convention was signed by ten of the signatories of the principal convention on the same day. The parties agreed to the creation of an International Criminal Court where terrorists who were not extradited or tried in the parties' own courts would be sent. This convention, as the main convention, never entered into force. ${ }^{279}$

Epps has been doubtful of the neutrality an international court. According to her, it would be extremely difficult to create a court that would grant the political offence exception to some political offenders without it expressing a particular political philosophy, "which would be anathema to some nations." Furthermore, many countries could refuse to submit to the jurisdiction of such a court. ${ }^{280}$

Based on the case examples presented in this study, it has become clear that courts have, actually, been equipped with the solutions to apply the POE so that it does not protect terrorists. The predominance test combined with the Belgian view weighing the severeness of the crime against its political goals would suffice in applying the POE. Another option would be the application of the existing criteria for asylum on political offenders. ${ }^{281}$ This would serve the purpose of protecting those who deserve protection and punishing those who use excessive means to pursue their political goals. It is noteworthy that the cases where the application of the POE has resulted in terrorists escaping have had more to do with foreign policy issues than with problems in the application of the exemption.

The option that has not yet been widely deliberated in this context would be to give terrorism a definition and to exclude these clearly defined offences from the protection of the POE internationally. In Chapter 2, Section 2.1.4, I suggested that terrorism could be defined as "violent criminal action aimed at persons used as symbolic targets with the objective of generating extreme fear in the general population, for the purposes of advancing political or ideological goals." 282 Should such a

278 Bassiouni, 1969, 257; Gilbert, 1985, 716-718; Groarke, 1988, 1543; Perry, 1989, 733; Gilbert, 1991, 156-157; Allan, 1993, 332; Gilbert, 1998, 316-320.

279 Oppenheim, Jennings and Watts, 1992, 970.

280 Epps, 1979, 86-87.

281 As Saul has pointed out, courts have already been struggling with similar issues in applying the asylum criteria as with applying the criteria for the application of the POE. Saul, 2015, 395.

282 Compare with Cassese, 2006, 937, who has argued that the generally agreed definitional elements of terrorism are that the acts are nationally criminalised, they are intended to provoke a state of terror or coerce a state or international organisation, and they are politically or ideologically motivated. See for further discussion on the definition e.g. Dugard, 1973; Schmid, 1984, 1992, 2011; Herbst, 2003; Saul, 2005; Fletcher, 2006; Young, 2006; Blakesley, 2007; Bryan, 2012; Wilkinson, 2012; Angli, 2013; and Di Filippo, 2014, amongst many others. 
formulation be accepted, it would be possible to retain the POE while excluding terrorists from its protection. It is clear that no definition is without problems and that all choices have the potential of underinclusiveness and/or overinclusiveness. This definition would, at least, catch the most serious terrorist offenders.

Excluding the defined acts from the POE would be a way to depoliticise the treatment of terrorists, as their acts would be separated from other forms of political crime. However, as the definition implies that terrorism always has a political or ideological goal, it does not attempt to hide its inherently political nature by depoliticising it and thus does not make an attempt to reduce it to common crime.

\subsection{The repoliticisation of terrorism}

\subsubsection{Do bad motives make worse criminals?}

While the key argument in this study is that terrorism has been depoliticised, this chapter hopes to open a window for further study discussing a contradictory notion: that concurrent to the depoliticisation of terrorism, the trend of repoliticisation is slowly emerging. This means that terrorists are growingly separated from the 'common criminal' category by creating terrorism-specific laws, containing harder punishments for crimes committed for terrorist purposes.

The aim is not to present an all-inclusive analysis on the phenomenon but merely to provide a starting point, hopefully opening new ground for further research on the topic. Additionally, the goal of this section is to provide an antithesis of my claim of depoliticisation. Political developments are by no means simple and harmonious, especially around such a complex phenomenon as terrorism, constituting of a variety of elements that include violence, politics, fear and unpredictability. For this reason, it is possible for two seemingly contradictory trends to exist side by side.

The repoliticisation of terrorism relates to its political motives. Does the motive of the crime make a difference to how the deed is judged? Is terrorism more wrong because its motivations are political? Robert Ferrari contemplated in 1920 that motive matters a great deal when measuring the right punishment for a specific act: "Do we not in our ordinary affairs of life consider motive, and does not that motive change the aspect of acts? Blind punishment for acts, applied indiscriminately to all who commit those acts, is worse than a crime of society; it is, as the French say, a blunder. And blunders are sometimes conducive to more startling, revolutionary results than crimes are."283

Ferrari's view has not been prevalent. In contrast, the motives of criminals have traditionally been kept out of courtrooms and considered irrelevant to criminal responsibility. ${ }^{284}$ If one begins to discuss the right-/wrongfulness of a moti-

283 Ferrari, 1920, 316.

284 See e.g. Kaufman, 2003, 317-318; Hessick, 2006; Saul, 2008, 1-3. However, as pointed out by e.g. Hessick, it is possible that the prosecutor might bring up evidence of a motive in an attempt to prove the guilt of the accused, but having a specific motive does not establish guilt. Hessick, 2006, 90, 94. 


\section{Fight against terrorism since the 1990s}

vation, the ideal objective nature of law is bent, and law and punishment become personalised according to each wrongdoer.

A criminal act is typically evaluated on two grounds only: first, whether the act committed was indeed illegal and whether it was the accused who committed the act in question. The second criterion is whether the accused had the necessary intent. In other words, their mental state, mens rea, is evaluated. After these two issues have been established, the question is whether they committed the act on purpose or by accident, for instance. An evaluation of motives is not part of this process. ${ }^{285}$

Because the evaluation of the person's motives necessitates understanding the reasons behind the commission of the crime, motivation is difficult to prove in court. ${ }^{286}$ In addition, the consideration of motives could lead towards treating some ideologies criminal. It could also undermine the role of the legal system as an (arguably) neutral system. ${ }^{287}$ If the only difference between the two acts is their motivation, treating the motivation as an essential element in the evaluation of the crime seems to lead to creating so-called thought crimes. The difficulty with this logic is that it necessitates the evaluation of the quality of the motive. What is a 'good' motive? Would an unselfish reason and motive make terrorism less wrong? ${ }^{288}$

An affirmative answer to this question would follow the logic of the political offence exemption, where the motive of doing 'greater good' has been one of the reasons why political criminals have been seen to deserve different treatment in comparison to common criminals.

With the repoliticisation of terrorism, the current take on political offenders seems to be opposite to that which emerged at the dawn of liberal democracies. Why has there been a change in the view a political motivation is looked at, why have political offenders again become villains instead of heroes?

Political crimes, and terrorism in particular, have throughout history received different treatment in comparison to 'common' crimes. At the lenient end of the spectrum of this special treatment of political crime, there is the political offence exception to extradition, discussed at lengths in the context of this book. The exception allows states to protect fugitives, regardless of the existence of extradition treaties. In addition to the POE, there have been other ways to provide political offenders with preferential treatment, for instance issuing them milder sentences or better imprisonment conditions.

285 See for a discussion between the differences between motive and intention, Husak, 1989, 5-6; and Kaufman, 2003, 321-326. See also Husak, 1989, 3; and Hessick, 2006, 90, 94-95. As pointed out by Husak, the concept of motive is also unclear to some extent. Husak, 1989, 5 .

286 Saul, $2008,5$.

287 See more on government neutrality and on this position Hessick has called 'neutralism' in Hessick, 2006, 90, 124.

288 See also Kaufman, 2003, 331. 
At the stricter end of the range, political criminals are sometimes considered as dangerous to the whole society, resulting in more severe measures against them. For instance, in the United States, political crime was traditionally viewed as more immoral than common crime, as it challenges the whole society, which is viewed as the guarantor of liberties. ${ }^{289}$ For instance, US President Warren Harding (1921-1923) claimed that there was no difference between political and common crime, and if such a difference did exist, political criminals would have been the ones deserving more serious punishments, as they threatened American institutions. ${ }^{290}$

Following English legal traditions, the United States has held a custom to depoliticise 'mixed' or 'relative' political crimes. These crimes were treated as common crimes, and their political motivations ignored. The ignorance of motive typically kept political ideologies out of American courtrooms. Even if in general, in the US, political criminals have been considered the most dangerous types of criminals, political offenders could still receive lesser penalties than common criminals. The juries used to be reluctant to convict political criminals, amnesties and pardons and suspended sentences were frequently used, and political prisoners have been able to get better treatment in federal prisons. ${ }^{291}$

Nowadays, terrorists, for example, have sometimes received harsher punishments than common criminals even when the material element of the act is the same. ${ }^{292}$ Both the lenient and the strict approach to political criminals have a long historical background. In this study, I refer to the treatment of terrorists as special cases and punishing terrorist acts more severely as the 'repoliticisation' of terrorism. The repoliticisation of terrorism seems to lead back to Ferrari's logic by making a murder committed with a terrorist intent a graver crime than a 'regular' murder.

It is noteworthy that in addition to terrorism, motivation has been added to some of the most recent criminalisations. For instance, a racist motivation for an act of violence can, in some jurisdictions, turn the crime into an entirely different crime, not just aggravate the sentence. ${ }^{293}$

Saul has noted that the motive requirement can target those acts that most bluntly are attacks against the society's core values. ${ }^{294} \mathrm{He}$ has argued that instead of denying the political element included in criminal law, criminal law can and should be used to defend democratic values by condemning certain types of violence. This would send a symbolic message that regardless of political motivations, serious violence is not acceptable in a democratic society. Such violence cannot be used to further political goals at the expense of other citizens' safety

289 Ingraham and Tokoro, 1969, 161.

290 McElrath, 2000, 14.

291 Ingraham and Tokoro, 1969, 149.

292 For instance, the US Federal Sentencing Guidelines provide for stricter limitations to crimes that "involved, or was intended to promote, a federal crime of terrorism." Hessick, 2006, 104-105.

293 See e.g. Blakesley, 2007, 169-171.

294 Saul, 2008, 4. 


\section{Fight against terrorism since the 1990s}

and security. Criminal law can thus be used to underline the inherent values of a democratic society. ${ }^{295}$ Interestingly, this is the opposite deduction to the one made in the 19th century, when it was thought that by offering political offenders more protection, it was possible to limit sympathies for them and prevent them from becoming martyrs of their cause. ${ }^{296}$

The problem with necessitating a specific motivation in the criminalisation of an act is that the motivation is difficult to prove. As such, these types of criminalisations may hinder effective prosecution. ${ }^{297}$ In the case of terrorism or hate crime, for instance, the role of the motive is to play a partially inculpatory role. The crimes themselves, regardless of motive, provoke criminal liability, but motive merely determines which crime the perpetrators are liable for ${ }^{298}$ In other words, the motive's "role is to distinguish between the relative blameworthiness of individuals who are liable for the same criminal offence." ${ }^{299}$ According to Smith and Damphousse, in hate crime legislation the motive of the perpetrator is required as an element of proof. ${ }^{300}$ Kaufman has noted that the fact that hate crimes necessitate a specific motive does not make the idea of the motive being generally irrelevant wrong; in these crimes, it has been the legislature that has defined the motives of the crimes. In other words, the courts do not make their decisions based on how right/wrong they see the crimes to be. ${ }^{301}$

Many have argued that motive has, in fact, never been irrelevant in courts. In addition to some criminal offences, such as the mentioned hate crimes, that have motive as an element, certain motives have in some cases been accepted defences and sometimes considered during sentencing. ${ }^{302}$ As put by Kaufman: "the criminal law does not depart from morality so as to ignore motive altogether." ${ }^{303}$ For instance, Smith and Damphousse have shown that terrorists are punished more severely than common criminals even when they are prosecuted as such. ${ }^{304}$

\subsubsection{Do terrovists have human rights?}

A terrorist deed is always a shock to a society. As such, it creates a sudden need to react politically. As Anna Oehmichen has shown, a legislative reaction to a terrorist act is often one that curtails human rights, even in societies that are known to promote them. ${ }^{305}$

295 Saul, 2008, 8.

296 Pyle, 2001, 81.

297 Saul, 2006, 40-41.

298 Hessick, 2006, 98.

299 Hessick, 2006, 101.

300 Smith and Damphousse, 1996, 290.

301 Kaufman, 2003, 318.

302 Husak, 1989, 3; Kaufman, 2003, 318; Hessick, 2006, 90.

303 Kaufman, 2003, 330.

304 Smith and Damphousse, 1996.

305 See for a very through analysis on the developments in antiterrorism laws from a human rights point of view, Oehmichen, 2009. See also e.g. Hallberg, 2004, 258-266. 
At least for the last 30 years, it has been questioned whether terrorists can get fair treatment in court. Wadie E. Said has argued that federal courts will stretch the boundaries of what is legally permissible when faced with a defendant charged with terrorism. According to Said, the criminal process is not necessarily an impartial forum when faced with non-state political violence. ${ }^{306}$ Concerns about terrorists not getting a fair hearing have been also expressed by, for instance, Gilbert. Because terrorist acts are extremely serious in nature and/or they aim at the state apparatus itself, they will most likely not get treated in the same way as ordinary crimes. Terrorists may end up getting punished for their political motives in addition to the act itself. ${ }^{307}$

When terrorists are taken into court as common offenders, they are not necessarily or even presumably treated in the same way as the average criminal. For instance, in England, 'safety' or 'urgent' interviews have been used mainly in cases that relate to terrorism. For the purpose of these interviews, the suspect's right to legal advice can be delayed. The police can use these interviews to receive information that might help them to protect life and/or prevent serious damage to property. The use of the information received during these interviews endangers the key rights of the suspect: the right to a fair trial, access to legal advice and against self-incrimination. ${ }^{308}$ There are known cases, where presumed terrorists have been denied access to a lawyer. In these cases, it has been argued, the European Court of Human Rights has not taken a strong stance towards the protection of the human rights of the presumed terrorists. ${ }^{309}$

There have been lots of discussions on how terrorists should be tried and whether there is a need for special courts and processes. Developments towards the extending of jurisdiction regarding terrorist crimes were seen already in the 1970s in relation to the Irish troubles. The UK Criminal Jurisdiction Act $1975^{310}$ and the Irish Criminal Law (Jurisdiction) Act $1976^{311}$ allowed courts in one country to try offenders in the other. The specific offences concerned were typically linked to what is generally understood as terrorism. As the Irish had refused to extradite members of the IRA due to the political offence exemption to extradition, the Acts were created to avoid this problem. ${ }^{312}$

Special rules and procedures have been supported for a variety of reasons. In the United States, the claim has been that regular processes could endanger Central Intelligence Agency (CIA) operatives abroad. This is due to the 'discovery' rule, which grants the accused the right to know what evidence is used against them in court. This rule has proved to create problems in many international terrorism trials, as information used against the accused might have been

306 Said, 2012, 176. See Said, 2015, for more details regarding terrorism prosecutions in the US.

307 Gilbert, 1985, 710; Gilbert, 1991, 156; Gilbert, 1998, 313-315.

308 See in more detail Wallerstein, 2013.

309 Dickson, 2013, 189-190.

310 Extraterritorial Offences, S. 4, Criminal Jurisdiction Act 1975 (c. 59).

311 S. 3, Irish Criminal Law (Jurisdiction) Act 1976, No. 14.

312 Gilbert, 1985, 718-719. 
obtained through paid informants or undercover operations by the CIA. The discovery process would have in many cases necessitated the release of names of intelligence agents. Because of this, a number of charges have been dropped. ${ }^{313}$ Also, the special security needs of terrorist trials have led to a questioning of whether terrorism trials can be organised in regular courthouses. The most common debate has concentrated on whether terrorist cases are too complicated to be tried by federal prosecutors. ${ }^{314}$

The debate about whether terrorists should be tried by military tribunals instead of ordinary courts seems to reflect a longer development towards treating terrorism as a more 'politicised' issue. As explained, traditionally in AngloAmerican law, political crime and political criminals are not separated from non-political criminals. Motive has not had relevance in court, only intent. ${ }^{315}$ For example, from the 1970s onwards, terrorists in the US were brought to ordinary courts as a demonstration that they were nothing more than ordinary criminals. ${ }^{316}$ The prosecutions of terrorists in regular courts have been relatively successful. ${ }^{317}$

Research conducted by Smith et al. has demonstrated a shift in antiterrorism policy in the US since the 1990s. Since then, international terrorism court cases have been growingly politicised. Also, the Federal Bureau of Investigation (FBI) has since 1983 applied specific guidelines and rules to terrorism investigations. Even if terrorists were still treated as common criminals in courtrooms, the shift in the FBI's procedures was the first indication of the coming change. The 'politicising' development continued throughout the 1980s. In court cases, a visible change took place towards the end of the decade, when three major terrorism trials took place in the United States. All of them were explicitly politicised, as they were brought to trial as seditious conspiracies. While the cases were politicised by calling them 'terrorism trials' or charging the accused with seditious conspiracy charges, the changes in the federal criminal code assisted in avoiding the discussion on the motivations for terrorism by incorporating a chapter called 'terrorism' into the code. The chapter allows for harsher sentencing for terrorist crimes. However, it does not define these by motivation, but instead by naming specific 'terrorist' targets. ${ }^{318}$ Thus, curiously, the 'politicisation' of terrorism court cases is partly in line with the tendency to 'depoliticise' the phenomenon, as the politicisation allows for stricter sentencing, while the depoliticisation makes it possible to ignore the motives behind terrorists' acts.

According to Smith et al., especially after the 1993 attacks against the World Trade Center in New York City, terrorism trials were explicitly politicised by the prosecutors. The bombers were labelled as terrorists throughout the trials. The charges, such as seditious conspiracy, openly linked a political motive

313 Smith et al., 2002, 327-328.

314 Smith et al., 2002, 313.

315 See e.g. Hagan, 1997, 4; and Saul, 2008, 1. See also Section 5.3.1.

316 Jackson, Damphousse and Smith, 2002, 314.

317 Smith et al., 2002, 329.

318 Smith et al., 2002, 313-316. 
with the acts. The attackers got convicted, which proved that the politicisation strategy could be efficient when bringing terrorists into trial. They did not need to be shrouded as common criminals. Notably, in the United States, the term 'terrorism' was a charge almost exclusively used against international terrorists. Domestic terrorists were consistently linked to other motives, whereas international terrorists motives were said to be 'terroristic' and thus political. ${ }^{319}$

A possible explanation for this partial paradox in the re- and depoliticisation trends is that domestic prosecutors are able to pursue more severe sentences for terrorists than to common criminals due to new antiterrorism laws. Internationally, on the other hand, the term terrorism is still debated and cooperation is easier to organise around less touchy matters.

Saul has argued against the common claim that including a motivational element to criminals could "legitimise them or transform them into cause célèbres, lightning rods for dissent or martyrs for the cause." In such a case, political claims brought to the judicial process would give these views more publicity and would force the law to take them seriously. ${ }^{320}$ Further, according to Saul, "Requiring proof of a political motive would expose fringe political claims to the judicial process, inevitably requiring the law to take serious notice of them and bringing them greater public attention. It was thought preferable to focus on the physical harm resulting from terrorist acts and, accordingly, to treat offenders as ordinary criminals." ${ }^{321}$ Jenkins has pointed out that arresting and imprisoning terrorists can, in fact, be useful for terrorists themselves, as courtrooms can be used to spread political ideas and captured terrorists can become martyrs for new generations. ${ }^{322}$

Regardless, for instance in Australia, terrorist acts are defined as certain violent criminal acts done "with the intention of advancing a political, religious or ideological cause," coupled with the intention of (1) "coercing, or influencing by intimidation" a government, or (2) "intimidating the public" or a section of it. Requiring a political, religious or ideological cause is widely understood as a motive requirement. In other words, there has to be a specific emotion or belief that prompts the violent act. ${ }^{323}$

Even with these problems linked with attaching political meaning to terrorists' actions, pushing the political element aside does not necessarily provide a simple solution. Terrorists' political demands usually get attention either through the media or the Internet, regardless of whether they are discussed in the court. ${ }^{324}$

In sum, some features that concern the special treatment of terrorists in comparison to common criminals have been listed earlier. These have included the creation of special tribunals, the (de)politicisation of terrorism cases and additional punishments for crimes with terrorist intent. In addition to these, there is

319 Smith et al., 2002, 316-325.

320 Saul, $2008,8$.

321 Saul, 2006, 39.

322 Jenkins, 2003, 73.

323 Division 101 of the Australian Criminal Code Act 1995.

324 Saul, $2008,8$. 
a recent development that further separates terrorism from the sphere of ordinary criminality. This is the ongoing tendency of criminalising the 'glorification' of terrorists or 'provocation to terrorism,' which is connected with the wider idea of the repoliticisation of terrorism. This development was already visible earlier, but it got accelerated with the 2002 EU Framework Decision on combating terrorism, ${ }^{325}$ amended in 2008 by another EU Framework Decision. ${ }^{326}$ These decisions require states to criminalise public provocation to commit a terrorist offence, as well as the intentional recruitment and training for terrorist purposes.

The (re)politicisation trend visible in United States court cases can also be noted in European legislation. In the United Kingdom, a new offence of inciting terrorism was introduced in the Terrorism Act 2000 (TA 2000). ${ }^{327}$ This was later followed by the Terrorism Act 2006 (TA 2006), which includes controversial offences, such as 'encouragement of terrorism' and the 'preparation of terrorist acts,' as well as the dissemination of terrorist publications. ${ }^{328}$ The encouragement or glorification of terrorism, for instance through public statements, has been criticised for clashing with the freedom of expression, as the act uses uncertain terms to define such deeds. ${ }^{329}$ The act does not sufficiently clarify what kind of statements are considered to encourage terrorism. Thus the final defining process falls into the hands of juries. ${ }^{330}$

The need for terrorism-specific laws in the United Kingdom has been a subject of debate, as similar acts could already be prosecuted under a provision such as incitement to murder. These were successfully used for instance in the case of the Imam Abu Hamza, who received a seven-year sentence. ${ }^{331}$ Nonetheless, the TA 2006 did introduce new criminalisations, but these have only been used on rare occasions. ${ }^{332}$

In France, it is possible to punish for the preparation and incitement to terrorism under non-terrorism specific statutes. The French criminal law has since 1881 contained an article $^{333}$ that relates to the glorification of terrorism, but very few cases have been prosecuted under this provision. ${ }^{34}$ The Spanish criminal law,

325 Council Framework Decision on Combating Terrorism, 2002/475/JHA, 13 June 2002.

326 Council Framework Decision 2008/919/JHA, 28 November 2008, amending Framework Decision on Combating Terrorism 2002/475/JHA, 13 June 2002.

327 Part 2, S. 3, 5, Terrorism Act 2000 (c. 11). See also incitement of terrorism overseas. Part 4, S. 59-61, Terrorism Act 2000 (c. 11).

328 Part 2, S. 3, 5A Terrorism Act 2006 (c. 11).

329 Oehmichen, 2009, 174; Cancio Melia and Petzsche, 2013, 87-88; Galli, 2013, 113-116.

330 Galli, 2013, 116.

331 R v. Abu Hamza [2006] EWCA (Crim) 456.

332 Galli, 2013, 115-116.

333 "Seront punis des peines prévues par l'alinéa ler ceux qui, par les mêmes moyens, auront provoqué directement aux actes de terrorisme prévus par le titre II du livre IV du code pénal, ou qui en auront fait l'apologie," Ch. 4, Para ler, Art 24(4) Loi du 29 juillet 1881 sur la liberté de la presse.

334 Galli, 2013, 117-118. 
in turn, contains an offence of 'justifying or glorifying' terrorist acts, ${ }^{335}$ but in Spain, this has been applied also to the glorification of terrorists themselves. This has resulted in scrutiny over speeches at terrorists' memorial services and of rock lyrics. Additionally, a wide variety of groups have been declared as terrorist, including youth organisations and prisoner support organisations. Further, Spain's laws are also very strict on terrorism, providing with a maximum prison term of 40 years for terrorism. Because of the unclear and encompassing nature of these new criminalisations, it has been argued that supporting terrorist organisations has become a so-called thought crime. ${ }^{336}$ Terrorism has also been repoliticised in Germany. After the EU Framework Decision of 2002, Germany added into its criminal code provisions of terrorism a description of political objectives. ${ }^{337}$ Prior to this, it was sufficient to have committed certain listed offences without any further subjective requirement. ${ }^{338}$

The UN Security Council also condemned "incitement to terrorism" in its Resolution 1624 following the terrorist attacks in London, ${ }^{339}$ and the Council of Europe Convention on the Prevention of Terrorism signatories agreed to criminalise "public provocation to commit a terrorist offence," which in the context of the treaty "means the distribution, or otherwise making available, of a message to the public, with the intent to incite the commission of a terrorist offence." 340

The criminalisation of inchoate offences is not without problems. ${ }^{341}$ The new offences have made the boundaries of criminal liability flexible and blurred. The link between the actual commission of a criminal act with criminal liability is feeble. They tend to emphasise the mens rea over the actus reus.

The repoliticisation has also been visible in terrorist sentencing. For instance, in Finnish law, the criminal use of explosives can be punished with a fine or with

335 "El enaltecimiento o la justificación por cualquier medio de expresión pública o difusión de los delitos comprendidos en los artículos 571 a 577 de este Código o de quienes hayan participado en su ejecución, o la realización de actos que entrañen descrédito, menosprecio o humillación de las víctimas de los delitos terroristas o de sus familiares." Article 578. Ley Orgánica 7/2000, de 22 de diciembre, de modificación de la Ley Orgánica 10/1995, de 23 de noviembre, del Código Penal, y de la Ley Orgánica 5/2000, de 12 de enero, reguladora de la Responsabilidad Penal de los Menores, en relación con los delitos de terrorismo.

336 Cancio Melia and Petzsche, 2013, 89-90. See more details on the Spanish antiterrorist legislation, Oehmichen 2009, 164-212.

337 For instance, with regard to the Associations Act, Vereinsgesetz, foreign associations could now be banned if they used violence in furtherance of political or other ideological causes. "Gewaltanwendung als Mittel zur Durchsetzung politischer, religiöser oder sonstiger Belange unterstützt, befürwortet oder hervorrufen soll.” Article 9, Terrorismusbekämpfungsgesetz (TerrorBekämpfG k.a.Abk.) G. v. 09.01.2002 BGBl. I S. 361, 3142.

338 Cancio Melia and Petzsche, 2013, 102-103.

339 UN Security Council Resolution 1624, UN Doc. S/RES/1624, 14 September 2005.

340 Council of Europe Convention on the Prevention of Terrorism, CETS No. 196, 16 May 2005.

341 See for a discussion on the tension between criminalisation of inchoate offences and the freedom of speech Ronen, 2014. 
up to two years imprisonment. ${ }^{342}$ Someone who commits the same crime with a terroristic intention can be sentenced to imprisonment of four months up to four years. ${ }^{343}$ Thus the purpose ${ }^{344}$ of the act will affect its sentencing.

It is interesting to note that like the depoliticisation strategy, the repoliticisation of terrorism is nothing new. For instance, as explained in Chapter 3, Section 3.2, the Anti-Anarchist Conference of Rome in 1898 also aimed at depoliticising terrorist acts in order to improve international collaboration against them and facilitate extradition procedures. At the same time, however, it created provisions that aimed at restricting the political liberties of anarchists and restraining the spread of anarchist thought. Punishment for crimes such as provocation or glorification seems to reflect the fear of the spread of the terrorists' ideas; not only the means they use.

Some traditional criminal lawyers have been alarmed by the creeping of motive into terrorist cases. ${ }^{345}$ Anna Oehmichen has, for instance, questioned the usefulness of such provisions and claimed that the prosecution of those that sympathise and glorify terrorists can, in fact, result in gaining more attention and sympathy for their cause. Additionally, it is simplistic to consider that terrorism could be curtailed by limiting freedom of speech. ${ }^{346}$ Furthermore, the definitions of terrorism used in these cases are broad. Thus it is possible that these criminalisations actually breach the lex certa principle. The additional problem with introducing inchoate offences is that they seem to allow the use of preventive powers and police powers long before an actual crime has occurred. In some cases, an ideological adherence to criminal purposes has been enough to trigger a criminal prosecution. 347

The recent criminalisations of inchoate offences and preparatory acts have been justified by claiming that they only target terrorists and their activities. They have also been labelled temporary, which has made them easier to accept. However, as pointed out by Francesca Galli, these kinds of 'temporary' measures have a tendency to eventually become normalised and applied in a wider scope that was originally planned for. ${ }^{348}$

342 Tahallinen räjähderikos, translated by author, Finnish Criminal Law, Ch 44, 11,16 December 2016/1143.

343 Finnish Criminal Law, Ch 34 a on Terrorism, 24 January 2003/17, $\$ 1$.

344 The terroristic purpose is defined in the following manner: "An offender has a terrorist intent if it is his or her intent to: (1) cause serious fear among the population, (2) unlawfully force the government of a state or another authority or an international organisation to perform, allow or abstain from performing any act, (3) unlawfully overturn or amend the constitution of a state or seriously destabilise the legal order of a state or cause particularly harm to the state economy or the fundamental social structures of the state, or (4) cause particularly extensive harm to the finances or other fundamental structures of an international organisation.” Finnish Criminal Law, Ch 34a, $\$ 6$.

345 Saul, 2008, 1.

346 Oehmichen, 2009, 174.

347 Galli, 2013, 121-122.

348 Galli, 2013, 124. 
The rule of law can be understood as a systemic trait of a democratic state. In a democratic state, fundamental and human rights are considered core values and the legality of the actions the representatives of the state are held dear. As a concept, the rule of law is often seen to incorporate the ideal of fair trials to all citizens. ${ }^{349}$ It also contains the principle of legality: no crime without law and no punishment without a crime. ${ }^{350}$ With such an ideal in mind, it is clear that the new antiterrorist provisions do not fit the traditional understanding of the rule of law, as they limit basic freedoms and curtail the rights of subjects.

\subsubsection{A threat to democracy}

It has become evident that a safeguard to the human rights of terrorism suspects is not guaranteed. Individuals can be punished before they have committed a crime, rather than only after the occurrence. Terrorists seem to have been placed in a special position, where they are not protected by the same boundaries of criminal law as other offenders. The German author Gunther Jakobs has named this 'Feindstrafrecht,' enemy criminal law. He supported the exceptional treatment of non-law abiding citizens, the enemies of the society. ${ }^{351}$

As the material act in a murder with a terroristic purpose is the same as in a 'common' murder, it is clear that there is a political difference between the two acts. Terrorists threaten the foundations of Western societies, democracy and the respect for human rights, and as a result, they are seen to deserve more severe treatment in comparison to other criminals. In this respect, the treatment of political criminals has gone full circle; as discussed in Chapter 3, Section 3.1.1, before the 19th-century political criminals were seen as the ultimate enemy that deserved the most severe treatment. As pointed out, according

349 Some of the most know definitions of the rule of law include Lord Bingham's criteria: "1. The law must be accessible, clear and predictable. 2. Questions of legal rights should be resolved by the law and not the exercise of discretion. 3 . The law should apply equally to all, except where objective differences justify differentiation. 4 . Ministers must act within their powers and not exceed their limits. 5. The law must afford adequate protection of fundamental human rights. 6 . The law should provide access to justice, especially where people cannot resolve inter-personal disputes themselves. 7. Courts and tribunal processes should be fair. 8. The state should comply with international law." Bingham, 2006. The Treaty on European Union set the following criteria for the rule of law in Article 49 and Article 6(1) for countries wishing to join the European Union. These criteria are called the Copenhagen criteria and they were established in 1993 and strengthened in 1995. They are: stability of institutions guaranteeing democracy, the rule of law, human rights, and respect for and protection of minorities; a functioning market economy and the ability to cope with competitive pressure and market forces within the EU; ability to take on the obligations of membership, including the capacity to effectively implement the rules, standards and policies that make up the body of EU law (the 'acquis'), and adherence to the aims of political, economic and monetary union. See also e.g. Hallberg, 2004, for a detailed study on the concept of rule of law.

350 Shkar, 1986, 152.

351 Galli, 2013, 123-124. 
to Ingraham and Tokoro the lenient treatment of political criminals is possible only when certain societal conditions are met. ${ }^{352}$ Have today's Western societies in one way or another returned to the conditions that existed 200 years ago? Or is the terrorism of today just such an exceptional threat that it deserves exceptional treatment?

Van den Wijngaert has raised an interesting question. "Assuming that there could be a difference in criminal responsibility between political and criminal offenders, how is this difference to be viewed? How should it be reflected in the penalty? Is the political motive to be considered as a mitigating or as an aggravating element? Are political offenders to be punished in the same way as common offenders, and, if not, which are the possible alternatives?" 353

The current day choice of punishing terrorists more gravely than common criminals who have committed similar acts seems to point to an idea that the political nature of the crime is what makes it more grave. This relates to the idea that political terrorists attack the whole democratic system, which, of course, makes them all the more dangerous. Terrorists do not only consider their actions as legitimate, but they also regard the whole system condemning them as illegitimate. This means that they are not deterred by punishment, which makes them a wild card in society.

For instance, Manuel Cancio Melia and Anneke Petzsche have argued that to some extent it is justified to punish terrorists more severely in comparison to 'ordinary' crimes. This is because the victims of terrorist attacks are not chosen because of their personalities, but because of what they represent. They are depersonalised and interchangeable, a mere means to an end. ${ }^{354}$ However, if a person shoots a random taxi driver in order to steal their car, the killer is not punished more severely because the killing of the driver only served the purpose of getting the car.

Some have suggested that terrorist acts should be considered crimes of war. This would mean that there would be no attempt to resocialise the perpetrators, but, instead, they would be interned until the 'war' was over. According to Van den Wijngaert, in some cases this could work, when there are periodic coups d'état and revolutions, but more generally this would typically mean life imprisonments. ${ }^{355}$ This is something we have witnessed with the treatment of the prisoners at Guantánamo Bay.

The preceding discussions have shown that actions against terrorists are often justified by the idea that terrorists are a threat to democracy as their fight is against democratic values, liberalism and freedom. Claiming to be acting for democracy is a powerful statement. It is so powerful that it can be used the wrong way. As Carl Schmitt wrote in 1932: "The worst confusion arises when concepts such as

352 Ingraham and Tokoro, 1969, 154.

353 Van den Wijngaert, 1980, 35.

354 Cancio Melia and Petzsche, 2013, 101.

355 Van den Wijngaert, 1980, 35-36. 
justice and freedom are used to legitimise one's own political ambitions and to disqualify or demoralise the enemy." 356

It has been demonstrated that there is a contradictory trend of repoliticising terrorism nationally, while there are international efforts to strip it from its political connotations. The paradox is obvious; while terrorism is called non-political on the global arena, on the national level there is a growing amount of legislation against issues such as the glorification of terrorism. I suggest that the concept of repoliticisation could be useful in conducting further research on more current day notions of terrorism.

Regardless of the evident paradox with the strategies of de- and repoliticising terrorism, they do not represent entirely contrasting phenomena. Both share the goal to condemn terrorists' acts in the strictest way possible. The depoliticisation strategy aims at doing this by facilitating antiterrorist cooperation internationally and diminishing the political goals behind terrorists' deeds, while the repoliticisation strategy aims at guaranteeing the harshest possible sentences and strong condemnation to terrorists domestically.

\subsection{Conclusion}

This chapter has suggested that the turnaround in Western antiterrorism policies took place in the 1990s and early 2000s. The developments described can be traced to the changes in the social and political conditions in the world, among the most important being the growth of the US influence and its increasing role as a world police. In the 1990s, terrorism was becoming more anti-American and religiously motivated, and the United States no longer faced the threat of the Soviet Union after its dispersal. This left room for the US to act more efficiently against terrorism. It partly channelled these efforts through the rewriting of its extradition treaties as well as through intensified collaboration within Interpol and the UN.

Coming to the latter part of the 1990s, the UN and Interpol embraced a view on terrorism as criminality more than as political action and depoliticised terrorist acts. Several motivations for the depoliticisation exist, including the diminishing of the adversary's political goals as well as the facilitation of international collaboration against terrorism, an inherently political phenomenon. The role of the US in affecting these changes can only be speculated within the confines of this study.

The POE had already received weakening blows since the 1970s with the coming into force of UN resolutions limiting its scope. After the creation of the 1985 Supplementary Treaty between the US and the UK, it was suggested that the POE had been annihilated. However, even if the treaty proved to be an important step towards that direction, the complete evisceration of the POE from treaties with allied states other than the UK did not occur, as the critics of the treaty had feared would happen.

356 Schmitt, 1996 (1932), 66. 
The most important blow to all relative and most pure political offences between Western nations was finally given by the limitations created in the 2000s as well as the removal of the POE from dealings amongst member states of the EU. Limitations that have been added to, for instance, treaties between the US and many EU member states exclude acts such as damage to property from the scope of the exception. As a result, no extralegal means of opposing a government, except to completely non-violent ones such as protests, can be protected by treaty partners. The political opponents of the ruling government are left armed with pens and pillows.

The case of pure political offenders is more complicated. It seems that the discrimination clause could offer them some protection. However, the application of the discrimination clause is, as previously concluded, foreign policy suicide between allied states. It has been used with non-allies, for instance in the Posada case, where the US refused Cuban and Venezuelan extradition requests based on the claim that Posada would not receive a fair trial in these countries.

My initial hypothesis, based on my previous research on Interpol, suggested that the role of the US was of major importance in the change that took place with regard to the POE. This seems to be partly true. The terrorist acts consummated against US citizens since the 1980s acted like triggers for the country, which had not been so much touched by Europe's terrorist problem in the previous decade. Especially the Kenya and Tanzania embassy bombings in 1998 seem to have made a major difference to US views on the terrorist threat. They also caused major changes within Interpol and the UN. However, the development had begun earlier and it seems to be linked to the UK as much as to the US.

This chapter has also touched upon the repoliticisation of terrorism. I feel that this development is worth more attention. It seemingly contrasts with my views on the depoliticisation, but, simultaneously, it points to an important underlying development. Both the de- and the repoliticisation of terrorism demonstrate that terrorism became perceived as such a massive threat to democratic nations that new means were necessitated in the fight against it. These means have included dealing with terrorism as an 'ordinary' crime, regardless of its motivations, but also criminalising acts that would, in liberalists' views, fall into the scope of the freedom of speech, for instance. Desperate times necessitate desperate means, it seems. 


\section{Conclusion \\ Protecting political offenders: pipe dream of romantic liberalism?}

\subsection{The demise of the political offence exception}

Recent developments concerning how the political nature of terrorism is dealt with have run two opposite ways. On the one hand, there is a growing crowd that argues in favour of the treatment of terrorists as common criminals. The basis for this argument lies in the trivialisation of terrorist acts. The aim has been to depict terrorists as rogues instead of heroes. On the other hand, the development has been the opposite. Terrorists are separated from the normal sphere of justice, special laws are applied to them and terrorist court cases are increasingly politicised. This has led to a contradictory situation, where terrorists are not subject to and protected by the same laws as common criminals, but their political goals are still swept under the carpet.

It seems that this development is due to the extremely political nature of terrorism. If politics is understood in Schmittian terms, where the political opponent represents the enemy, the stranger, ${ }^{1}$ and "[ $\left.\mathrm{t}\right]$ he political is the most intense and extreme antagonism," it becomes clear that terrorists are in fact the ultimate political enemy. As discussed throughout this book, the political offence exception (POE) was created to protect all kinds of political criminals, from activists to violent offenders. It was a result of the rise of a liberal ideology in the spirit of the revolutionary period in the 1800s and its purpose was to support those fighting for liberal ideals. The exemption was a child of its own time, and when faced with growingly complicated situations, as well as criminal methods and means unheard of in the 19th century, its relevance was subjected to tests.

Throughout its existence, the political offence exemption has created diplomatic problems. The first difficulties arose with revolutionaries attempting to create political change by assassinating heads of state. As a result, such acts were excluded from the scope of political offences, a development led by Belgium. This provision that was added to a majority of extradition treaties was to be known as the Belgium clause, or, more commonly, the attentat clause. The limitations to the POE were further extended to cover acts of genocide, wars crimes,

1 Schmitt, 1996 (1932), 27.

2 Schmitt, 1996 (1932), 29. 
apartheid and finally acts of terrorism, which proved to be the most problematic issue the exemption had faced during its history.

Regardless of the highly ideological, even idealist, background of the POE, states have, for some reason, been trying to apply it in a neutral manner. It has been considered a principle that is free from ideological considerations and that could be applied neutrally to political offenders, based on specific 'tests.' Because of the legislator's hesitancy to attach any ideological criteria to the principle, courts have been left with the task to blindly apply the said tests to offenders of different political backgrounds. This aim to stay neutral with regard to the application of the POE has led to problems.

Despite the growing amount of limitations excluding a variety of violent acts from the POE, it still has sometimes been used to protect those who commit terrorist acts. This is in contrast with the original aims of the exception. According to Geoffrey Gilbert, the original purpose of the POE was to protect those who aspired to establish liberal democratic governments. For this reason: "To try and apply the doctrine to the late twentieth century, especially to the issue of transnational terrorism, results in the confusion and injustice so prevalent. The exemption was aimed to protect people fighting for liberal democracy, yet the same language is still applied today to persons intent on destroying liberal democracy. It is evident, therefore, that the exemption may be in need of reassessment and it may need to be redrafted, insofar as this is possible." 3

Similarly, Manuel R. García-Mora, writing in 1956, underlined the importance of not sheltering those he called 'subversives,' that is anarchists, terrorists or communists, who were the enemies of all governments. He contrasted the intentions of these people with those of genuine political offenders who act against a particular government. For this reason, subversives did not need to be protected in democratic states. ${ }^{4}$ Abraham Sofaer, writing 30 years later, agreed: "If civilised society is to defend itself against terrorist violence, some offences committed in or against stable democracies must fall outside the scope of the exception, even though they are politically motivated." 5

As noted by Christopher H. Pyle, there has been a long struggle with trying to balance the political offence exception with the philosophical idea of the right to revolt. ${ }^{6}$ Attempts have been made to exclude wanton acts against civilians from the scope of the protection. Some examples of such an approach have been represented in the attentat clause, the Meunier case and the Eain case as well as in multilateral treaties. Nonetheless, there has not been a consistent approach to this issue and it has not always been successful.

Nowadays, there is a rather wide consensus that terrorist deeds should not be protected by the POE, especially when committed in democratic countries. The

3 Gilbert, 1991, 115. See also Gilbert, 1991, 122; and Gilbert, 1998, 205.

4 García-Mora, 1956, 88.

5 Sofaer, 1986, 128.

6 See e.g. Pyle, 2001, 157. 
exclusion of terrorism from the scope of the political offence exemption can be seen to reflect the idealistic view of liberal democratic revolutionaries fighting for a just cause. If the POE is understood to serve the purpose of spreading liberal democratic ideas, neither the radical leftist terrorists of the 1960s and 1970s nor the Islamist terrorists of the 2000s would fall under the protection of the exemption.

Even if the POE was originally built on a rather clear ideological basis, aiming at protecting liberals, states have been reluctant to apply it based on these ideas. Evaluating political crimes based on the legitimacy of their goals leads to a political decision. In many countries, extradition was originally created as a judicial function, which was meant to be unaffected by political considerations. For this reason, there have been attempts to deny the political nature of the POE and attempts to consider it a politically neutral judicial principle, i.e. a template that could be applied in a neutral fashion.

The claimed neutrality in applying the POE served a foreign policy function. As discussed, the POE assisted states in acting in a seemingly impartial way towards other states' political struggles. The condemning of specific political causes openly, no matter how transparent and true, could result in later political problems.

As the POE was created based on specific ideological considerations, it seems strange that democratic nations are not able to stand by their beliefs and values in supporting liberalist causes. As noted by for instance Shkar, the law is never neutral. In fact, she has argued that the "deliberative isolation of the legal system the treatment of law as a neutral social entity - is itself a refined political ideology, the expression of a preference." Why is there an attempt to hide the democratic principles the law intends to serve?

Without a political decision of what political crime is and what constitutes an acceptable political cause, with a shared view on which methods are acceptable for furthering such a cause, it is impossible to make 'ideal' extradition decisions which would be independently applied by the judiciary based on laws the legislature has created. A simple solution to this would be to open up the ideological motivations for holding on to the POE: who do we wish to protect and under which circumstances?

Regardless of the limitations to the POE, states have been suspicious of whether these are sufficient to exclude all terrorists from its protection. For this reason, the POE has continuously been limited by states in their extradition treaties as well as by international organisations such as the United Nations (UN) and Interpol. Some have claimed that the POE no longer serves any purpose, especially between democratic states abiding by the rule of law. Such a conclusion led to its annihilation within the European Union (EU). However, it is questionable whether such a claim is well founded. As discussed, the leap from democracy to dictatorship is not massive and the step from the rule of law to 
limiting citizens' rights is even smaller. For this reason, it seems too optimistic to claim that there is no longer need for any protection of political offenders within the EU or amongst a wider group of states.

\subsection{The delegitimisation of terrorism}

One of the strategies used to exclude terrorist acts from the scope of the POE has been the depoliticisation of specific terrorist acts. The aim of the depoliticisation has been for instance to end discussions over terrorists' goals by defining terrorism without making reference to their political motives. It should also automatically exclude terrorist acts from the protection of the POE, even if this has not proven to work this simply.

In the context of international treaties, the depoliticisation of terrorism has been common. One of the main research questions presented in the introductory chapter of this book was "How and when did the current trend of depoliticising terrorism emerge?" It has been shown in this study that terrorism has been depoliticised growingly and globally since 1977 when the European Convention on the Suppression of Terrorism was created. This convention used the same strategy as the Anti-Anarchist Conference of Rome of 1898 and depoliticised offences that typically relate to terrorism. The aim in both instances was to exclude terrorists from the protection of the political offence exception to extradition. Even if the 1977 convention was a clear step away from considering terrorism a political phenomenon, and towards treating it as common crime, it is telling that in its statement regarding the convention, France noted, "Furthermore, taking action against terrorism does not absolve us from tackling the political problem of the causes of terrorism. For in many respects the real struggle against terrorism is a struggle for a just peace which guarantees everyone's legitimate rights." ${ }^{8}$ Nowadays, this kind of statement would be unlikely due to the fear of unintentionally legitimising violent acts. The motivations of terrorism are not brought up or discussed.

Later, the International Criminal Police Organisation (Interpol) depoliticised terrorism by separating the specific criminal offences from the concept of terrorism. This way, perpetrators of terrorist acts could be subject to criminal investigations without the need to discuss their political motivations. Also, the United Nations has, especially since the 1990s, focused on the material elements of terrorist acts and left aside the motivation of these acts, thus depoliticising them. Several UN conventions have been created, which include acts that are most commonly seen as terrorist. The depoliticisation in the case of the UN has been done due to difficulties in agreeing on a definition of terrorism.

The depoliticisation strategy is, as discussed, problematic in many ways. Most important, it is problematic because it essentially denies the political nature of

8 Statements, reservations and declarations: France. European Convention on the Suppression of Terrorism Strasbourg, European Treaty Series No. 90, 27 January 1977. 
certain acts and for this reason, seems illogical. As established, terrorism is in its essence and by definition political crime. In order to understand and fight a phenomenon that is so strongly connected with ideologies, it is important that its motivations are not forgotten. Considering terrorist acts common crimes and ignoring their political motivations will result in avoiding the discussion on the terrorists' goals and ideologies. Nevertheless, it should be possible to discuss the roots of terrorism and where this inherently political phenomenon stems from. Denying the political nature of terrorism is not a way of repressing the use of terroristic methods.

The 'false' and very much illogical depoliticisation of terrorism served as a 19th-century solution to a 20th- (and later 21 st-) century problem. When dealing with anarchist crimes, this strategy had a bit more logic in it: anarchism was contra all governments and organised methods of ruling. It was thus possible to consider this 'apolitical.' Saying anarchism has nothing to do with politics seems to make some sense, even if in the general understanding anarchism is inherently political.

However, terrorism is a label put on a method used by violent criminals driven by ideological thought. As it has been defined as such for decades, the idea that it can be depoliticised seems to be unreasoned. Why does there need to be a specific definitional category for terrorism if there is no specific element that separates it from common criminality, mass murders and wanton bombings?

The second research question was "Was the political offence exception to extradition affected by terrorism?" As demonstrated, the depoliticisation strategy is closely linked to the existence of the political offence exception. As the POE was created for the purpose of defending those that fight for liberal ideas, it turned out to be problematic once it became clear that also others might end up being protected by it. Nowadays, extradition is an important tool in securing trials for fugitives such as former political leaders, military generals, and terrorists. What these crimes and extradition requests have in common is their connection with political questions. It has become clear that the POE can be used either in a restrictive manner or an expansive manner, and also that it has never been free of ideological weight.

In 1980, Van den Wijngaert argued that the "implicit positive significance" of the term political crime was a creation of the liberal democratic state. Totalitarian regimes saw political offenders as the most dangerous among all criminals. Their criminal justice systems gave broad and vague definitions and harsh punishments for these crimes, as well as lower or non-existing procedural safeguards with regard to political offenders. Extradition law points to the same conclusion, as totalitarian states did not typically have the so-called POE, and the extradition of political criminals was the norm rather than an anomaly.

According to Van den Wijngaert, the protection of the political offender can be seen as an inherently democratic principle, and the depoliticisation was the means to not derogate from this doctrine. The depoliticisation, however, was problematic, as it was done merely to hold on to the principle of the non-extradition 
of political offenders, and resulted in calling political crimes non-political. ${ }^{9}$ In relation to Van den Wijngaert's analysis, the development described in this book regarding the depoliticisation of terrorism and the abolishing of the POE is highly interesting, as it seems that one of the two would suffice in achieving the goal of ending the protection of terrorists.

As suggested, together with the (international) depoliticisation of terrorism, there has been a (national) trend of repoliticising terrorism. Laws designed to prevent the spread of the 'terrorist message,' for instance, have been created. Terrorism has become a separate category in the national law of many countries and thus it is separated from other forms of crimes around the world.

The final main research question presented in this study was "Why did these changes occur and what are their implications?" Even if it seems that the deand repoliticisation of terrorism are contrasting strategies, after a more thorough analysis, it has become clear that they actually serve the same purpose. They both aim at delegitimising terrorists and facilitating antiterrorist actions. The depoliticisation does this by labelling terrorists common criminals, which excludes them from the category of selfless freedom fighters and helps to unify states against them. Simultaneously, the repoliticisation of terrorism on the national level provides for a stronger condemnation of terrorist acts as opposed to other, seemingly similar acts with no political goals or implications.

If we consider that liberalism has won the battle over ideologies, and democracy is the system to strengthen and support, it can be argued that both the deand repoliticisation strategies are, in fact, in stark contradiction with this idea. Depoliticisation turns the fight against the opponents into a technical matter, dealt with within the criminal justice system. As such, it does not take advantage of the common understanding that democratic ideals are worth protecting and use the opportunity to explain the reasons why these criminals are more dangerous to society than others. Repoliticisation, in turn, does also not serve as a value-based attack against those who target liberal nation states. As such, it does suggest that terrorism is reprehensible, but seems to assume the existence of a 'terror-ism,' an ideology that escalates as violence. Such an ideology does not exist, as terrorism is a means rather than an ideology. As a means, it can be used by any ism. It should be understood that terrorist action stems from a political background but is not itself an ideology. As such, the politics and crime should be separated from one another, but at the same time, one should not be forgotten when discussing the other.

\subsection{Final questions}

It has become clear that the existence of the political offence exception has affected not only extradition processes but also wider matters. Due to the existence of the POE, two alternative strategies have been used to prevent terrorists from escaping justice. First, politically motivated crimes, such as terrorism, have

9 Van den Wijngaert, 1980, 101-102. 
been depoliticised so that they could be subject to extradition. Second, the scope of the POE has been restricted.

These developments raise questions: Has the perhaps naive liberalist cause suffered a painful death, or have we indeed reached 'the end of history' where political dissidents no longer need protection? Are our democracies so stable that we can abolish all protection for political offenders within these countries? Or have we thrown the baby out with the bathwater when we have, in trying to eliminate all protection for terrorists, also potentially eliminated protection for non-violent political dissidents?

As demonstrated in this study, several different reasons led to the politicisation of the POE, meaning that it would only be used selectively to protect 'acceptable' political dissidents, champions of democracy or otherwise useful people. As criminal law is based on the principle that it has to be predictable, the weighing of the perpetrator's goals' legitimacy is highly problematic unless the aims of the application of the principle are openly stated.

This problem relates especially to the application of the POE by the judicial branch. Due to the political nature of the application of the exemption, passing the decision-making power to the executive has been suggested and planned. This would create the positive effect of publicising the political nature of the decisions and underlining the inherently political aim of the POE, which is to protect those fighting for liberal democracy. The current situation in many countries is that a decision of high political significance is given to the judiciary and cloaked in 'neutrality.'" This is an unwanted solution.

For some reasons, democratic nations have refused to openly protect only offenders who have perpetrated crimes in an attempt to further liberalist causes. The status of the judiciary as an impartial organ is compromised if the judiciary is asked to remain neutral in a matter that is considered highly political by the executive, without clear guidelines from the legislature. Being open about the political roots and aims of the POE would also prevent the problems that relate to its application to terrorist cases. Terrorist acts against liberal democratic states are inherently contrasting to the original goals of the POE, which means that they would not be protected by it.

Unfortunately, giving the decision-making powers to the executive would by no means be an easy fix for the problem posed by the POE. One of the key purposes of the POE was to prevent states from meddling in the political affairs of another state. This goal of neutrality would most likely still be of value. Giving the application of the POE to the hands of the executive would turn it into a completely political decision and shift its application according to the changes in decision-making organs. Such an uneven application of a legal construction would contrast constitutional principles in many states.

As demonstrated, within the EU the problems presented by the existence of the POE have been solved by abolishing the POE altogether. The historical

10 See a lengthy discussion on the 'neutrality' of the law in Shklar, 1986. 


\section{Conclusion}

pattern presented in this book suggests that such a decision could be taken amongst other Western states in the coming years. For instance, the POE in the US-UK extradition treaty is already extremely limited.

Can it be said that political crime then has no place in our societies today? As a reminder, the conditions under which, according to Ingraham and Tokoro, a separate concept of political crime and toleration towards this type of criminals can arise are

(1) [when] the dominant political philosophy [is] liberalism, (2) where the state's claim to legitimacy [is] infirm and relativistic, (3) where there [is] a clear division between the concept of the state (as merely representative of those interests in society politically in the ascendant) and the society as a whole, and (4) where the government's or the state bureaucracy's conception of itself [is] not as the representative of all the people of the society, but rather as the custodian or protector of a constitutional order which ensure [s] the institutions constituting the source of its political and economic power. ${ }^{11}$

Have these conditions ceased to exist in modern-day societies?

As demonstrated by the cases of whistle-blowers such as Assange, Snowden and Manning, it is clear that there is room for political crime in democratic societies. These cases also prove that seemingly similar nations can strongly disagree on whether a specific act is a crime or a selfless act supported by the highly valued principles of freedom of speech or freedom of the press, for instance.

For this reason, to abolish the POE is dangerous; we have not reached the end of history, liberal democracy has not won. There are different representatives of the concept of liberal democracy and no way of telling who represents the true cause. The use of the exemption is highly political, thus it has to be either defined properly or brought to the 'political' openly, thus away from the courts. The quickest fix would be to retain the POE but to come up with a shared definition of terrorism. Whether this is possible in the near future is left to be seen.

I wish to end this study by citing the late Charles Tilly, a well-known scholar of sociology and political science:

Collective violence occupies a perilous but coherent place in contentious politics. It emerges from the ebb and flow of collective grievances and struggles for power. It interweaves incessantly with non-violent politics, varies systematically with political regimes, and changes as a consequence of essentially the same causes that operate in the non-violent zones of collective political life. Understanding those causes will help us minimise the damage human beings inflict on each other. In our own violent time, advocates of non-violent political struggle need all the help they can get. ${ }^{12}$

11 Ingraham and Tokoro, 1969, 154.

12 Tilly, 2003. 


\section{Summary}

This book has examined the complicated nature of the relationship between the political nature of terrorism on the one hand and the political offence exception to extradition on the other. Political crime is, by nature, different from other types of crime from the perspective of the state. It has, for this reason, received particular treatment for as long as the state system has existed. This study demonstrates a notable change in the ways in which political crime and especially terrorism have been viewed globally during the last half a century.

The political offence exemption, the child of revolutionary liberalism, was added to almost all extradition treaties around the world after the French and American revolutions in the late 18th century. During recent times, the exception, sometimes considered a part of customary international law, has slowly been suffocated by the complexity of the phenomenon called terrorism that emerged in the decades following the Second World War.

The exception was developed in the romantic and forward-looking ethos of the 19th century, where the winds of liberal thought seemed to be blowing from all directions and newborn national states were finding their footholds in the emerging ideology of democracy. It was created to protect those who fought the 'ancien régime' and would become new leaders in the dawn of a more egalitarian world. Upon the creation of the exemption, it was never imagined that the political offender could turn against a democratic state.

The political offence exemption survived the challenge posed by Nazi crimes and could be modified to exclude war crimes. It also proved flexible enough to provide for the ruling out of crimes such as genocide. It was however not indestructible; the straw that finally broke the camel's back turned out to be terrorism. With its elusive nature, ever-extending scope, growing efficient means and, most of all, its antidemocratic nature, terrorism has become too much of a societal threat that strategies that had previously safeguarded the exception were no longer sufficient.

As democracies have growingly been threatened by political violence during the last few decades, concerns with regard to the existence of the political offence exception have been expressed. At first, states made attempts to exclude terroristic acts and means from the protection of the political offence exception by ruling them out, one by one, in separate conventions. However, this proved too 


\section{Summary}

complex. Increasingly, it was perceived as vital to condemn the whole phenomenon and tag it with a name.

In order to secure the capturing of terrorists, many scholars and politicians alike have wished for the exception to be modified, limited or even abolished. Political efforts have been made in order to exclude violent and indiscriminate acts from the scope of its protection. There has been some success: for instance, the US-UK Supplementary Treaty of 1985 managed to limit the possibilities of IRA members in fleeing abroad to escape justice.

Simultaneously with the limitations to the political offence exemption, sometimes called the politicisation of the exception, an effort has been made to globally depoliticise acts of terrorism. This has been done for several reasons, including the fact that a depoliticised crime cannot be protected by the exception. Thus there has been a two-direction attack against terrorism on the conceptual agenda.

Finally, within the European context, a solution was agreed upon. The depoliticisation of terrorism that had first been used in the late 19th century in the attempt to suppress anarchist terrorism was reinstated as a reaction to the terrorist wave that hit Europe in the 1970s. The European Convention on the Suppression of Terrorism in 1977 was the first instance to depoliticise terrorism since the Anti-Anarchist Conference of Rome of 1898. Since then, the depoliticisation wave has slowly progressed to cover the Western world as well as, step by step, a large number of United Nations member states. On the European level, it has reached a final stage with the eradication of the political offence exception with the coming into force of the European Arrest Warrant in 2004.

Thus, as a result of the seemingly necessary actions against terrorists, other political offenders, including those using non-violent means, have lost their protection with the abolishing of the political offence exception. This development is an undesirable one, as the world has not reached an end where there is no longer room for political crime. The present book suggests that terrorism should be internationally defined and excluded from the political offence exception, which in turn should be revived. 


\section{Sources and bibliography}

\subsection{Multilateral conventions, resolutions and recommendations}

\section{(Chronological order)}

Commonwealth Fugitive Offenders Act of 1881. 44 and 45 Vic. c. 69 (Imperial).

First South American Congress on Private International Law, Treaty on International Penal Law, 23 January 1889.

Propositions arrêtées par la Conférence internationale réunie à Rome sur l'initiative du Gouvernement Italien en vue d'étudier et d'établir les moyens les plus efficacies pour combattre la propaganda anarchique et soumises par elle à l'appreciation des Gouvernements qui s'y trouvaient représentés. December 21, 1898, Rome. Published in Kinna, Ruth, Early Writings on Terrorism, vol. 3, Routledge, London and New York, 2006, 326-329 (The final propositions of the AAC of Rome, 1898).

Treaty for the extradition of criminals and for the protection against anarchism. Second International Conference of American States, Doc No 330, 22 October 1901-31 January 1902.

Código de Derecho Internacional Privado (Código de Bustamante). Convención de Derecho Internacional Privado, 20 February 1928.

Convention Relating to the International Status of Refugees. League of Nations, Treaty Series Vol. CLIX No. 3663, 28 October 1933.

Convention on extradition adopted by the Seventh International Conference of American States (Montevideo Convention), 26 December 1933.

Convention for the Prevention and Punishment of Terrorism. League of Nations, 16 November 1937.

Convention on the Prevention and Punishment of the Crime of Genocide, UNTS No. 1021, 9 December 1948.

Universal Declaration of Human Rights (UDHR), GA Res 217 A, 10 December 1948.

Convention (I) for the Amelioration of the Condition of the Wounded and Sick in Armed Forces in the Field (Geneva Convention I), 12 August 1949.

Convention (II) for the Amelioration of the Condition of Wounded, Sick and Shipwrecked Members of Armed Forces at Sea (Geneva Convention II), 12 August 1949.

Convention (III) relative to the Treatment of Prisoners of War (Geneva Convention III), 12 August 1949. 
Convention (IV) relative to the Protection of Civilian Persons in Time of War (Geneva Convention IV), 12 August 1949.

United Nations Convention Relating to the Status of Refugees, 28 July 1951.

Protocol Relating to the Status of Refugees, 606 UNTS 267, 31 January 1967.

Declaration on Territorial Asylum, UN GA Res 2312 (XXII), 14 December 1967.

The Arab States and the Arab League Extradition Agreement, 14 September 1952.

The Pan American Convention on Territorial Asylum, 28 March 1954.

Interpol Constitution I/CONS/GA/1956, 13 June 1956.

European Convention on Extradition, ETS No. 24, 13 December 1957.

European Convention on Mutual Assistance in Criminal Matters, ETS No. 30, 20 April 1959.

Treaty between the Kingdom of Belgium, the Grand Duchy of Luxembourg and the Kingdom of the Netherlands Concerning Extradition and Mutual Assistance in Criminal Matters, 27 June 1962.

Scheme Relating to the Rendition of Fugitive Offenders within the Commonwealth, H.M.S.O. (Cm 3008, 1966).

Protocol Relating to the Status of Refugees, 606 UNTS 267, 31 January 1967.

Declaration on Territorial Asylum, UN GA Res 2312 (XXII), 14 December 1967.

Convention for the Suppression of Unlawful Seizure of Aircraft (The Hague Convention), 860 UNTS 105, 16 December 1970.

Convention for the Suppression of Unlawful Acts Against the Safety of Civil Aviation (The Montreal Convention), 974 UNTS 177, 23 September 1971.

Report of the Special Committee of the United Nations on International Terrorism, G.A.O.R., Supp. No. 28 (XXVII); United States' Draft Convention for the Prevention and Punishment of Certain Acts of International Terrorism (US Draft Convention for the Prevention and Punishment of Terrorism Acts), UN Doc. A/C.6/L850, 25 September 1972.

Parliamentary Assembly of the Council of Europe, Recommendation 684 on International Terrorism, 23 October 1972.

Measures to Prevent International Terrorism Which Endangers or Takes Innocent Human Lives of Jeopardises Fundamental Freedoms, and Study of the Underlying Causes of Those Forms of Terrorism and Acts of Violence Which Lie in Misery, Frustration, Grievance and Despair and Which Cause Some People to Sacrifice Human Lives, Including Their Own, in an Attempt to Effect Radical Changes. Study prepared by the Secretariat in accordance with the decision taken by the Sixth Committee at its 1314th meeting, on 27 September 1972 (Measures to Prevent International Terrorism, 1972), UN Doc. A/C.6/418, 2 November 1972.

Parliamentary Assembly of the Council of Europe Recommendation 703 on International Terrorism, 16 May 1973.

Convention on the Prevention and Punishment of Crimes against Internationally Protected Persons, including Diplomatic Agents. 1035 UNTS 167, 14 December 1973.

Council of Europe Resolution (74) 3 on International Terrorism, 24 January 1974.

Additional Protocol to the European Convention on Extradition, ETS No. 86,15 October 1975.

European Convention on the Suppression of Terrorism, ETS No. 90, 27 January 1977. 
Explanatory Report to the European Convention on the Suppression of Terrorism, ETS No. 90, 27 January 1977.

Protocol Additional to the Geneva Conventions of 12 August 1949, and relating to the Protection of Victims of International Armed Conflicts (Protocol I), 8 June 1977.

Protocol Additional to the Geneva Conventions of 12 August 1949, and relating to the Protection of Victims of Non-International Armed Conflicts (Protocol II), 8 June 1977.

Second Additional Protocol to the European Convention on Extradition, ETS No. 98, 17 March 1978.

Parliamentary Assembly of the Council of Europe, Recommendation 852 on Terrorism in Europe, 31 January 1979.

Agreement Concerning the Application of the European Convention on the Suppression of Terrorism among the Member States of the European Communities (the Dublin Convention). Assembly Document 4460, 17 December 1979.

The International Convention Against the Taking of Hostages (Hostage taking Convention), 1316 UNTS 205, 17 December 1979.

Measures to Prevent International Terrorism Which Endangers or Takes Innocent Human Lives or Jeopardises Fundamental Freedoms, and Study of the Underlying Causes of Those Forms of Terrorism and Acts of Violence Which Lie in Misery, Frustration, Grievance and Despair and Which Cause Some People to Sacrifice Human Lives, Including Their Own, in an Attempt to Effect Radical Changes. UN General Assembly Resolution, UN Doc. A/RES/34/145, 17 December 1979.

Inter-American Convention on Extradition, 25 February 1981.

Parliamentary Assembly Council of Europe, Recommendation 916 on the Conference on "Defence of Democracy Against Terrorism in Europe - Tasks and Problems." 26 March 1981.

Measures to Prevent International Terrorism Which Endangers or Takes Innocent Human Lives or Jeopardizes Fundamental Freedoms, and Study of the Underlying Causes of the Forms of Terrorism and Acts of Violence Which Lie in Misery, Frustration, Grievance and Despair and Which Cause Some People to Sacrifice Human Lives, Including Their Own, in an Attempt to Effect Radical Changes. UN General Assembly Resolution, UN Doc. A/RES/36/109, 10 December 1981

Council of Europe Committee of Ministers, Recommendation of the Committee of Ministers to Member States Concerning International Co-operation in the Prosecution and Punishment of Acts of Terrorism. No. R (82), Adopted by the Committee of Ministers at the 342nd meeting of the Ministers' Deputies, 15 January 1982.

League of Arab States, Riyadh Arab Agreement for Judicial Cooperation, 6 April 1983.

Measures to Prevent International Terrorism Which Endangers or Takes Innocent Human Lives or Jeopardises Fundamental Freedoms, and Study of the Underlying Causes of Those Forms of Terrorism and Acts of Violence Which Lie in Misery, Frustration, Grievance and Despair and Which Cause Some People to Sacrifice Human Lives, Including Their Own, in an Attempt to Effect Radical Changes. UN Doc. A/RES/38/130, 19 December 1983.

Convention against Torture and Other Cruel, Inhuman or Degrading Treatment or Punishment (CAT). UN Doc. A/RES/39/46, 10 December 1984.

Council of Europe Parliamentary Assembly, Recommendation 982 on the Defence of Democracy Against Terrorism in Europe, 9 May 1984. 
Inadmissibility of the Policy of State Terrorism and Any Actions by States Aimed at Undermining the Socio-political System in Other Sovereign States. UN Doc. A/ RES/39/159, 17 December 1984.

Measures to Prevent International Terrorism Which Endangers or Takes Innocent Human Lives of Jeopardises Fundamental Freedoms, and Study of the Underlying Causes of Those Forms of Terrorism and Acts of Violence Which Lie in Misery, Frustration, Grievance and Despair and Which Cause Some People to Sacrifice Human Lives, Including Their Own, in an Attempt to Effect Radical Changes. UN Doc. A/RES/40/61, 9 December 1985.

UN Security Council Resolution 579 on Hostage Taking, UN Doc. S/RES/579, 18 December 1985.

Council of Europe, Resolution 863 on the European Response to International Terrorism, 18 September 1986.

South Asian Association for Regional Cooperation (SAARC) Regional Convention on the Suppression of Terrorism, 4 November 1987.

Declaration on the Enhancement of the Effectiveness of the Principle of Refraining from the Threat or Use of Force in International Relations. UN Doc. A/ RES/42/22, 18 November 1987.

Measures to Prevent International Terrorism Which Endangers or Takes Innocent Human Lives or Jeopardises Fundamental Freedoms, and Study of the Underlying Causes of Those Forms of Terrorism and Acts of Violence Which Lie in Misery, Frustration, Grievance and Despair and Which Cause Some People to Sacrifice Human Lives, Including Their Own, in an Attempt to Effect Radical Changes. UN Doc. A/ RES/42/159, 7 December 1987 and UN Doc. A/RES/44/29, 4.12.1989.

UN Model Treaty on Extradition. Annex: UN Doc. A/RES/45/116, 14 December 1990.

UN Model Treaty on Mutual Assistance in Criminal Matters. Annex: UN Doc. A/ RES/45/116, 14 December 1990.

Measures to Eliminate International Terrorism. UN Doc. A/RES/46/51, 9 December 1991.

Handbook on Procedures and Criteria for Determining Refugee Status under the 1951 Convention and the 1967 Protocol relating to the Status of Refugees, HCR/IP/4/ Eng/REV. UNHCR 1979, Reedited, January 1992.

Treaty on European Union (Maastricht Treaty), OJ 92/C 191/01, 7 February 1992.

UN Security Council Resolution 731 on Libyan Arab Jamahiriya. UN Doc. S/ RES/731, 21 January 1992.

UN Security Council Resolution 748 on Libyan Arab Jamahiriya. UN Doc. S/ RES/748, 31 March 1992.

UN Security Council Resolution 883 on Libyan Arab Jamahiriya. UN Doc. S/ RES/883, 11 November 1993.

Report of the International Law Commission on the work of its forty-third session (29 April-19 July 1991). Yearbook of the International Law Commission, 1994, Vol. II, Pt. 2, Pt. 2, UN Doc. A/46/10.

Declaration on Measures to Eliminate International Terrorism, annexed to the Measures to Eliminate International Terrorism. UN Doc. A/RES/49/60, 9 December 1994.

Convention, drawn up on the basis of Article K.3 of the Treaty on European Union, on simplified extradition procedure between the Member States of the European Union, O.J.1995, C 78/2, 10 March 1995. 
Council Act drawing up the Convention based on Article K.3 of the Treaty on European Union, on the establishment of a European Police Office (Europol Convention). 95/C 316/01, 26 July 1995.

Measures to Eliminate International Terrorism. UN Doc. A/RES/49/60, 17 February 1995.

Measures to Eliminate International Terrorism. UN Doc. A/RES/51/210, 17 December 1996.

Convention, drawn up on the basis of Article K.3 of the Treaty on European Union, relating to extradition between the Member States of the European Union. O.J. 1996, C 313/12, 27 September 1996.

Measures to Eliminate International Terrorism. UN Doc. A/RES/52/165, 16 January 1997.

Convention for the Suppression of Terrorist Bombings (Terrorist Bombing Convention). UN Doc. A/Res/52/164, 9 January 1998.

Rome Statute of the International Criminal Court, UN Doc. A/CONF.183/9, 17 July 1998.

Resolution 1192 adopted by the UN Security Council at its 3920th meeting. UN Doc. S/RES/1192, 27 August 1998.

Acuerdo sobre extradición entre los estados partes del Mercosur, 10 December 1998.

Treaty on Cooperation among the States Members of the Commonwealth of Independent States in Combating Terrorism, 4 June 1999.

Organisation of African Unity Convention on the Prevention and Combating of Terrorism, 14 July 1999.

Convention for the Suppression of the Financing of Terrorism (Terrorism Financing Convention). UN Doc. A/54/109, 9 December 1999.

UN Security Council Resolution 1269 on the Responsibility of the Security Council in the Maintenance of International Peace and Security. UN Doc. S/RES/1269, 19 October 1999.

Measures to Eliminate International Terrorism. UN Doc. A/RES/54/110, 9 December 1999.

Draft Comprehensive Convention on International Terrorism. UN Doc. A/C.6/55/1, 28 August 2000.

Threats to International Peace and Security Caused by Terrorist Acts. UN Doc. S/ RES/1368, 12 September 2001.

European Commission, Proposal for a Council Framework Decision on Combating Terrorism, COM (2001) 521 Final, 2001/0217 (CNS), 19 September 2001.

Council of Europe Parliamentary Assembly, Resolution 1258 on Democracies Facing Terrorism, 26 September 2001.

UN Security Council Resolution 1373 Threats to International Peace and Security Caused by Terrorist Acts. UN Doc. S/RES/1373, 28 September 2001.

UN Security Council Resolution 1377 Declaration on the Global Effort to Combat Terrorism. UN Doc. S/RES/1377, 12 November 2001.

Measures to Eliminate International Terrorism. UN Doc. A/RES/58/81, 9 December 2001.

Council of Europe Parliamentary Assembly Recommendation 1550, Combating Terrorism and Respect for Human Rights, 24 January 2002.

Council Framework Decision of 13 June 2002 on the European Arrest Warrant and the Surrender Procedures between Member States - Statements Made by certain 
Member States on the Adoption of the Framework Decision. 2002/584/JHA, OJ L 190, 18 July 2002.

Council Framework Decision of 13 June 2002 on Combating Terrorism. 2002/475/ JHA, OJ L 164, 22 June 2002.

Committee of Ministers of the Council of Europe, Guidelines on Human Rights and the Fight Against Terrorism. H (2002) 4, 11 July 2002.

The London Scheme for Extradition within the Commonwealth, Incorporating the Amendments Agreed at Kingstown in November 2002.

Measures to Eliminate International Terrorism. UN Doc. A/RES/57/27 19 November 2002.

Protocol Amending the European Convention on the Suppression of Terrorism. ETS No. 190, 15 May 2003.

Agreement on Extradition between the European Union and the United States of America. OJ L 181/27, 19 July 2003.

UN Security Council Resolution 1624. UN Doc. S/RES/1624, 14 September 2005. Council of Europe Convention on the Prevention of Terrorism. CETS No. 196, 16 May 2005.

Resolución No 8: Extradición de Luis Posada Carriles XXIII Asamblea Ordinaria del Parlamento Latinoamericano Ciudad de Panamá, República de Panamá, 6-7 December 2007.

Consolidated version of the Treaty on the Functioning of the European Union Protocol (No 24) on asylum for nationals of Member States of the European Union. OJ 115/24, 9 May 2008.

\subsection{Bilateral extradition conventions}

\section{United States}

Some of the existing conventions are not listed, as they were signed when the signatory states were not independent. To the author's knowledge, only three other treaties are missing from the listing: the 1874 US-Salvador and the 1924 US-Bulgaria and USRomania treaties. It is, however, possible that some other treaties are also missing. Please see the Appendix for a table categorising all these treaties and their provisions concerning terrorism and political crime.

The Webster-Ashburton Treaty. Treaty to Settle and Define the Boundaries between the Territories of the United States and the Possessions of Her Britannic Majesty in North America, for the Final Suppression of the African Slave Trade, and for the Giving Up of Criminals Fugitive from Justice, in Certain Cases, 1842. 8 Stat. 572, 9 August 1842 .

Convention for the Surrender of Criminals between the United States of America and His Majesty the King of the French, 9 November 1843.

Convention for the Mutual Delivery of Criminals, United States and Germany (Prussia and Germanic Confederation), 16 June 1852.

Convention between the United States of America and the Austro-Hungarian Monarchy Relating to Extradition for the Mutual Delivery of Criminals, Fugitives from Justice, in Certain Cases, 3 July 1856.

United States-Haiti Treaty on Amity, Commerce and Navigation and the Extradition of Criminals. 3 November 1864. 
Ecuador International Extradition Treaty with the United States, 28 June 1872.

United States-Turkey Extradition Treaty, 11 August 1874. ${ }^{1}$

United States-Belgium Extradition Treaty, 13 June 1882.

United States-Japan Extradition Treaty, 29 April 1886.

United States-Russia Extradition Treaty, 16(28) March 1887.

United States-Netherlands Extradition Treaty, 2 June 1887.

Convention between the United States of America and Colombia for the Reciprocal Extradition of Criminals, 7 May 1888.

Convention between the United Kingdom and the United States of America for the Mutual Extradition of Fugitive Criminals, 12 July 1889.

United States-Norway Extradition Treaty, 7 June 1893.

United States-Argentina Extradition Treaty, 26 September 1896.

United States-Brazil Extradition Treaty, 14 May 1897 and 28 May 1898.

United States-Mexico Extradition Treaty, 22 February 1899.

Chile International Extradition Treaty with the United States, 17 April 1900.

United States-Bolivia Extradition Treaty, 21 April 1900.

Supplementary Convention between the United Kingdom and the United States of America for the Mutual Extradition of Fugitive Criminals, 13 December 1900.

Extradition Treaty between the Government of the United States of America and the Government of the Swiss Confederation, 14 May 1900.

Slovenia (Former Yugoslavia) International Extradition Treaty with the United States, 25 October 1901.

United States-Belgium Extradition Treaty, 26 October 1901.

United States-Denmark Extradition Treaty, 6 January 1902.

Treaty between the United States and the Republic of Guatemala for the Mutual Extradition of Fugitives from Justice, 27 February 1903.

Treaty between the United States and Cuba for the Mutual Extradition of Fugitives from Justice, 6 April 1904.

United States-Spain Extradition Treaty, 15 June 1904.

United States-Haiti Extradition Treaty, 9 August 1904.

Nicaragua International Extradition Treaty with the United States, 1 March 1905.

United States-Uruguay Extradition Treaty, 11 March 1905.

San Marino International Extradition Treaty with the United States, 10 January 1906.

Portugal International Extradition Treaty with the United States, 7 May 1908.

Convention d'extradition entre la France et les Etats-Unis d'Amérique, 6 January 1909.

Congo International Extradition Treaty with the United States, 6 January 1909.

Honduras International Extradition Treaty with the United States, 15 January 1909.

Dominican Republic International Extradition Treaty with the United States, 19 June 1909.

Treaty of Extradition between the United States of America and El Salvador, 18 April 1911.

Convention between the United Kingdom and the United States of America Concerning Extradition (Supplementary), 15 January 1917.

Extradition Treaty between the United States of America and Turkey, 6 August 1923.

1 Treaties that have no specific title have been marked as United States-(other state) Extradition Treaty, date. 


\section{Sources and bibliography}

Treaty between the United States and Latvia for the Extradition of Fugitives from Justice, 16 October 1923.

Extradition Convention between the United States of America and Estonia, 8 November 1923.

Extradition Treaty between Bulgaria and the United States of America, 19 March 1924.

Czechoslovakia International Extradition Treaty with the United States, 2 July 1925.

Treaty of Extradition between the United States of America and the Republic of Poland, 22 November 1927.

Convention between the United States of America and Austria Regarding the Reciprocal Extradition of Criminals, 31 January 1930.

Extradition Treaty between Germany and the United States of America, 12 July 1930.

Greece International Extradition Treaty with the United States, 6 May 1931.

Extradition Treaty between His Majesty, in Respect of the United Kingdom, and the President of the United States of America, 22 December 1931.

Albania International Extradition Treaty with the United States, 1 March 1933.

Iraq International Extradition Treaty with the United States, 7 June 1934.

Liechtenstein International Extradition Treaty with the United States, 20 May 1936. Liberia International Extradition Treaty with the United States, 1 November 1937.

Monaco International Extradition Treaty with the United States, 15 February 1939.

Supplementary Convention to the Extradition Treaty Concluded between the United States of America and the Republic of Guatemala, 20 February 1940.

Treaty between the United States of America and the Union of South Africa Relating to Extradition, 18 December 1947.

Extradition Treaty and Additional Protocol between the United States of America and Brazil, 13 January 1961.

Convention on Extradition between the United States of America and Sweden, 24 October 1961.

Israel International Extradition Treaty with the United States, 10 December 1962.

Singapore Extradition Treaty - Exchange of Notes with the United States. Extradition: Continued Application to Singapore of the United States-United Kingdom Treaty of 22 December 1931, 23 April 1969.

Treaty on Extradition between the United States of America and New Zealand, 12 January 1970.

Spain International Extradition Treaty with the United States, 29 May 1970.

Treaty on Extradition between the Government of Canada and the Government of the United States of America, 3 December 1971.

Treaty on Extradition between the United States of America and the Republic of Argentina, 21 January 1972.

Extradition Treaty between the Government of the United Kingdom of Great Britain and Northern Ireland and the Government of the United States of America, 8 June 1972.

Kiribati International Extradition Treaty with the United States, 8 June 1972.

Treaty on Extradition between the Kingdom of Denmark and the United States of America, 22 June 1972.

Treaty on Extradition between the United States of America and Italy, 18 January 1973.

Treaty on Extradition and Cooperation in Penal Matters between the United States of America and the Oriental Republic of Uruguay, 6 April 1973. 
Treaty on Extradition between the United States of America and the Republic of Paraguay, 24 May 1973.

Treaty on Extradition between Australia and the United States of America, 14 May 1974.

Extradition Treaty between the United States of America and Finland, 11 June 1976.

Extradition Treaty between the Government of the United Kingdom of Great Britain and Northern Ireland and the Government of the United States of America (With Protocol of Signature) (together with Exchange of Notes Extending the Treaty to Certain Territories), 21 October 1976.

Extradition Treaty between the United States of America and the Kingdom of Norway, 9 June 1977.

Japan International Extradition Treaty with the United States, 3 March 1978.

Mexico International Extradition Treaty with the United States, 4 May 1978.

West Germany (FRG) International Extradition Treaty with the United States, 20 June 1978.

Treaty on Extradition and Mutual Assistance in Criminal Matters between the United States of America and the Republic of Turkey, 7 June 1979.

Colombia International Extradition Treaty with the United States, 14 September 1979.

Extradition treaty between the Kingdom of the Netherlands and the United States of America, 24 June 1980.

Costa Rica International Extradition Treaty with the United States, 4 December 1982.

Extradition Treaty between the Government of the United States of America and the Government of Jamaica. 14 June 1983.

Treaty on Extradition between Ireland and the United States of America, 13 July 1983.

Extradition Treaty between the Government of the United States of America and the Government of the Republic of Italy, 13 October 1983.

Thailand International Extradition Treaty with the United States, 14 December 1983.

The Supplementary Treaty to the Treaty between the United States of America and the Federal Republic of Germany Concerning Extradition, 21 October 1986.

Supplementary Treaty between the Government of the United Kingdom of Great Britain and Northern Ireland and the Government of the United States of America, 25 June 1985, concerning the 8 June 1972 Extradition Treaty. Amended 19 and 20 August 1986.

Convention d'extradition entre le Royaume de Belgique et les Etats-Unis d'Amérique, 27 April 1987.

Second Supplementary Treaty on Extradition between the United States of America and the Kingdom of Spain, 9 February 1988.

Extradition Treaty between the Government of the United States of America and the Government of the Swiss Confederation, 14 November 1990.

Treaty between the Government of the United States of America and the Government of the Republic of Hungary on Extradition, 1 December 1994.

Jordan International Extradition Treaty with the United States, 28 March 1995.

Treaty between the Government of the United States of America and the Government of the Republic of Bolivia on Extradition, 27 June 1995.

Extradition Treaty between the Government of the United States of America and the Government of Malaysia, 3 August 1995. 


\section{Sources and bibliography}

Extradition Treaty between the Government of the United States of America and the Government of Barbados, 28 February 1996.

Extradition Treaty between the Government of the United States of America and the Government of the Republic of Trinidad and Tobago, 4 March 1996.

Extradition Treaty between the Government of the United States of America and the Government of Saint Lucia, 18 April 1996.

Extradition Treaty between France and the United States of America, 23 April 1996.

Extradition Treaty between the Government of the United States of America and the Government of Grenada, 30 May 1996.

Antigua and Barbuda International Extradition Treaty with the United States, 3 June 1996.

Extradition Treaty between the Government of the United States of America and the Government of the Republic of Cyprus, 17 June 1996.

Poland International Extradition Treaty with the United States, 10 July 1996.

Extradition Treaty between the Government of the United States of America and the Government of Saint Vincent and the Grenadines, 15 August 1996.

Extradition Treaty between the United States of America and the Grand Duchy of Luxembourg, l October 1996.

Extradition Treaty between the Government of the United States of America and the Government of Dominica, 10 October 1996.

China (Hong Kong) International Extradition Treaty with the United States, 20 December 1996.

India International Extradition Treaty with the United States, 25 June 1997.

Extradition Treaty between the Argentina Republic and the United States of America, 10 July 1997.

Extradition Treaty between the Government of the United States of America and the Government of the Republic of Zimbabwe, 25 July 1997.

Extradition Treaty between the Government of the Republic of Austria and the Government of the United States of America, 8 January 1998.

Extradition Treaty between the Government of the Republic of Korea and the Government of the United States of America, 9 June 1998.

Extradition Treaty between the Government of the Republic of Paraguay and the Government of the United States of America, 9 November 1998.

Extradition Treaty between the Government of the United States of America and the Government of the Republic of South Africa, 16 September 1999.

Extradition Treaty between the Government of the United States of America and the Government of the Democratic Socialist Republic of Sri Lanka, 30 September 1999.

Extradition Treaty between the Government of the United States of America and the Government of Belize, 30 March 2000.

Extradition Treaty between the United States of America and Lithuania, 23 October 2001.

Extradition Treaty between the Government of the United States of America and the Government of the Republic of Peru, 26 July 2001.

Extradition Treaty between the Government of the United Kingdom of Great Britain and Northern Ireland and the Government of the United States of America, 31 March 2003.

Protocol between the Government of the State of Israel and Government of the United States amending the Convention on Extradition signed at Washington D.C. 10 December 1962, 6 July 2005. 
Latvia International Extradition Treaty with the United States, 7 December 2005.

Second Supplementary Treaty, Amending the Treaty of 2 July 1925, as Amended by the Supplementary Treaty of 29 April 1935, between the United States of America and the Czech Republic, 16 May 2006.

Extradition Treaty between the Government of the Republic of Estonia and the Government of the United States of America, 8 February 2006.

Romania International Extradition Treaty with the United States, 10 September 2007. Bulgaria International Extradition Treaty with the United States, 19 September 2007.

\section{European states}

Convention d'extradition France-Belgique, 29 April 1869.

Convention d'extradition France-Belgique, 15 August 1874.

Treaty on Extradition between France and the United Kingdom of Great Britain and Northern Ireland, 14 August 1876.

Treaty between the Argentina Republic and Her Britannic Majesty for the Mutual Surrender of Fugitive Criminals, 22 May 1889. Amended by the Protocol of 12 December 1890.

Traité d'extradition entre la France et la Grèce, 11 April 1906.

Convention d'extradition entre la France et les Etats-Unis d'Amérique, 6 January 1909.

Convention d'extradition entre la Bulgarie et la France, 29 December 1911.

Extradition treaty between the United Kingdom and Finland, 30 May 1924.

Traité d'extradition entre la France et la Pologne, 30 December 1925.

Extradition convention between Estonia and Finland, 2 January 1925.

Convention relating to Extradition and Judicial Assistance in Criminal Matters between Austria and Finland, 22 October 1928.

Extradition Treaty between His Majesty, in respect of the United Kingdom, and the President of the Polish Republic, 11 January 1932.

Convention franco-allemande d'extradition, 29 November 1951.

Tratado de extradiçáo entre o Brasil e a Bélgica, 6 May 1953.

Convention d'extradition entre la France et l'état d'Israél, 12 November 1958.

Treaty between the Kingdom of Belgium, the Grand Duchy of Luxembourg, and the Kingdom of the Netherlands Concerning Extradition and Mutual Assistance in Criminal Matters, 27 June 1962.

Treaty Between Canada and the Federal Republic of Germany Concerning Extradition, 11 July 1977.

Tratado de extradição entre a República do Brasil e o Reino da Espanha, 2 February 1988.

Extradition Treaty between the Government of Canada and the Government of the Republic of France, 17 November 1988.

Treaty of Extradition Between Canada and Spain, 31 May 1989.

Tratado de extradição entre o Brasil e a República Italiana, 17 October 1989.

Extradition Treaty between the Government of the Republic of India and the Government of the United Kingdom of Great Britain and Northern Ireland, 30 December 1993.

Treaty on Extradition between the Government of Canada and the Government of Sweden, 15 February 2000.

Treaty Between the Government of Canada and the Government of the Italian Republic Concerning Extradition, 13 January 2005. 


\section{Other states}

Tratado de extradicíon, República de Colombia y República de Panama, 24 December 1927.

Tratado de extradição entre o Brasil e a Bolivia, 25 February 1938.

Extradition Treaty between the Government of Canada and the Government of India, 6 February 1987.

Tratado de extradição entre o Governo da República Federativa do Brasil e o Governo do Canada, 27 January 1995.

Acuerdo sobre extradición entre el Mercosur, la República de Bolivia y la Republica de Chile, 10 December 1998.

Treaty between the Government of Canada and the Government of the Republic of South Africa on Extradition excluding for instance murder, inflicting serious bodily harm and sexual assault from the protection of the POE, 12 November 1999.

\subsection{Interpol resolutions}

\begin{tabular}{|c|c|c|}
\hline $\mathrm{AGN} / 20 / \mathrm{RES} / 11$ & Requests for international enquiries & Lisbon, 1951 \\
\hline $\mathrm{AGN} / 4 \mathrm{l} / \mathrm{RES} / 7$ & Hostages and blackmail & Frankfurt, 1972 \\
\hline $\mathrm{AGN} / 48 / \mathrm{RES} / 8$ & $\begin{array}{l}\text { Acts of violence committed by } \\
\text { organised groups }\end{array}$ & Nairobi, 1979 \\
\hline $\mathrm{AGN} / 50 / \mathrm{RES} / 2$ & Tagging of explosives & Nice, 1981 \\
\hline $\mathrm{AGN} / 52 / \mathrm{RES} / 9$ & Terrorism & Cannes, 1983 \\
\hline $\mathrm{AGN} / 53 / \mathrm{RES} / 6$ & $\begin{array}{l}\text { Violent crime commonly referred to } \\
\text { as terrorism }\end{array}$ & Luxembourg, 1984 \\
\hline $\mathrm{AGN} / 53 / \mathrm{RES} / 7$ & $\begin{array}{l}\text { Application of Article } 3 \text { of the } \\
\text { constitution }\end{array}$ & Luxembourg, 1984 \\
\hline $\mathrm{AGN} / 54 / \mathrm{RES} / 1$ & $\begin{array}{l}\text { International terrorism and unlawful } \\
\text { interference with civil aviation }\end{array}$ & Washington, DC, 1985 \\
\hline $\mathrm{AGN} / 55 / \mathrm{RES} / 3$ & $\begin{array}{l}\text { Co-operation in terrorist cases; } \\
\text { Guide for NCBs and specialized } \\
\text { services }\end{array}$ & Belgrade, 1986 \\
\hline AGN/63/RES/9 & $\begin{array}{l}\text { Application of Article } 3 \text { of the } \\
\text { Constitution in the context of } \\
\text { serious violations of international } \\
\text { humanitarian law }\end{array}$ & Rome, 1994 \\
\hline $\mathrm{AGN} / 64 / \mathrm{RES} / 8$ & Monitoring of resolutions & Beijing, 1995 \\
\hline $\mathrm{AGN} / 67 / \mathrm{RES} / 6$ & $\begin{array}{l}\text { New Guidelines for Co-operation } \\
\text { in Combating International } \\
\text { Terrorism }\end{array}$ & Cairo, 1998 \\
\hline AGN $/ 67 / \mathrm{RES} / 12$ & Cairo declaration against terrorism & Cairo, 1998 \\
\hline AGN/68/RES/2 & The financing of terrorism & Seoul, 1999 \\
\hline AG-2001-RES-05 & $\begin{array}{l}\text { Terrorist attack of } 11 \text { September } \\
2001\end{array}$ & Budapest, 2001 \\
\hline AG-2005-RES-10 & $\begin{array}{l}\text { Addressing Internet activities } \\
\text { supporting terrorism }\end{array}$ & Berlin, 2005 \\
\hline AG-2006-RES-09 & $\begin{array}{l}\text { Home-grown terrorists - al-Qaeda } \\
\text { linked/al-Qaeda inspired terrorism }\end{array}$ & Rio de Janeiro, 2006 \\
\hline
\end{tabular}


AG-2008-RES-06 Increasing the sharing of information Saint Petersburg, 2008 in terrorist-related matters, using the available INTERPOL tools and the Fusion Contact Officers network

AG-2009-RES-15 Draft Arrangement on Co-operation Singapore, 2009 between the International Criminal Police Organisation-INTERPOL and the United Nations in relation to the United Nations Security Council Sanctions Committees supplementary arrangement to the Co-operation Agreement between the International Criminal Police Organisation-INTERPOL and the United Nations

\subsection{Case law/legal cases}

\section{European Court of Human Rights}

Soering v. the United Kingdom, Application no. 14038/88, 7 July 1989.

\section{Canada}

Chitat Ng v. Canada, Communication No. 469/1991, U.N. Doc. CCPR/ C/49/D/469/1991 (1994).

Gil v. Canada (M.E.I.), [1995] I F.C. 508 (F.C. Appeal).

\section{France}

Holder, Cour d'Appel, Paris, Jugement de 14 April 1975.

Abu Daoud, D.S.I.R. 352, Gaz. du Palais 105, 11 January 1977. See also 104 J. Du DR. INTL 843 (1977).

Croissant, Cour d'Appel, Paris, 16 November 1977, 2nd decision, 93 J.Trib. (1978). Piperno, Cour d'Appel, Paris, 17 October 1979.

Barabass and Hofmann, Cour d'Appel, Paris, Jugement de 9 July 1980.

McCann, Cour d'Appel, Aix-en-Provence, Jugement de 13 December 1978. Affatigato, Cour d'Appel, Aix-en-Provence, Jugement de 5 September 1980. Astudillo-Calleja, Conseil d'Etat, Paris, Jugement de 24 June 1977.

In re Galdeano, Ramirez and Beiztegui, 1985. (See in more detail Gilbert, 2006.)

\section{Switzerland}

Wassijlieff case [1909] Foreign Relations. U.S. 519 (1914).

In re Ockert, Bundesgericht, Oct. 20, 1933, 59(1.) Entscheidungen des Schweizerischen Bundesgerichtes 136, 137, [1933-34] Ann. Dig. 369, 370 (No. 157) (Swit.). 
In re Nappi, 19 LL.R. 375 (Fed. Trib., Switz., 1952).

In re Kavic, [1952] Int'l L. Rep. 371 (No. 80) (Swit.).

Ktir v. Ministere Public Federal (1961) 235.

Della Savia contro Ministero pubblico della Confederazione, BGE 95 I 462 (1969).

\section{United Kingdom}

In re Castioni [1890] 1 Q.B. 149.

Regina v. Governor of Brixton Prison, Ex Parte Kolczynski [1955] I Q.B. 540.

Reg. v. Governor of Pentonville Prison, Ex Parte Tzu-Tsai Cheng [1973] A.C. 931 Q.B. Cf. Ferrandi v. Governor of Brixton Prison, DC/205/81 [1981] (MWC), Q.B.D.

$T$ v. Secretary of State for the Home Department [1995] 2 All E.R. 1042, [1994] 1 W.L.R. 545.

Tv. Secretary of State for the Home Department [1996] 2 All E.R. 865.

\section{United States}

In re Ezeta. In re Bolanos, In re Colocho. In re Cienfuegos. In re Bustamante. 62 F. 972,

(District Court, N.D. California, 1894).

Ornelas v. Ruiz 161 U.S. 502 (1896).

United States v. Tapolcsanyi 40 F.2d 255 (3d Cir. 1930).

Kjar v. Doak 61 F.2d 566 (7th Cir. 1932).

United States v. Artukovic 170 F. Supp. 383 (S.D. Cal. 1959).

Ramos v. Diaz 179 F. Supp. 459 (S.D. Fla. 1959).

In re Mylonas 187 F. Supp. 716 (N.D. Ala. 1960).

In re Gonzalez 217 F. Supp. 717 (S.D.N.Y. 1963).

Garcia-Guillern v. United States, 450 F.2d 1189, 1192 (5th Cir. 1971).

Escobedo v. United States 623 F.2d 1098, 1104 (5th Cir. 1980).

Eain v. Wilkes 641 F.2d 504 (7th Cir. 1981).

In re Mackin 668 F.2d 122 (USCA 2nd Cir. 1981).

In re Doherty 599 F.Supp. 270 (S.D.N.Y.1984).

Quinn v. Robinson 783 F.2d 776 (9th Cir. 1985).

McMullen v. Immigration and Naturalisation Service 788 F.2d 591 (USCA 9th Circ. 1986).

Ahmad v. Wigen 726 F. Supp. 389 (E.D.N.Y. 1989), aff'd, 910 F.2d 1063 (2d Cir. 1990).

Extradition of Smyth 820 F. Supp. 498 (N.D. Cal. 1993).

In re: Requested Extradition of Smyth 61 F.3d 711 (USCA 9th Cir. 1995).

In re Extradition of Singh 170 F. Supp. 2d 982 (E.D. Cal. 2001).

Meza v. U.S. Att'y Gen. 693 E3d 1350, 1353 (11th Cir. 2012).

\subsection{Legislation}

\section{Australia}

Division 101 of the Australian Criminal Code Act 1995.

Security Legislation Amendment (Terrorism) Act 2002. 


\section{Finland}

Finnish Criminal Law, Ch 34a on terrorism, 24 January 2003/17.

Finnish Criminal Law, Ch 44 on crimes that endanger public health or safety, 16 December $2016 / 1143 .^{2}$

\section{France}

Déclaration des Droits de l'Homme et du Citoyen de 1789.

Loi du 29 juillet 1881 sur la liberté de la presse.

Loi du 10 mars 1927 relative à l'extradition des étrangers, 10 March 1927.

\section{Germany}

Terrorismusbekämpfungsgesetz (TerrorBekämpfG k.a.Abk.) G. v. 09.01.2002 BGBl. I S. 361, 3142.

\section{Republic of Ireland}

Irish Criminal Law (Jurisdiction) Act 1976, No. 14.

\section{Spain}

Ley Orgánica 7/2000, de 22 de diciembre, de modificación de la Ley Orgánica 10/1995, de 23 de noviembre, del Código Penal, y de la Ley Orgánica 5/2000, de 12 de enero, reguladora de la Responsabilidad Penal de los Menores, en relación con los delitos de terrorismo.

\section{United Kingdom}

Treason Act 1351 c. 2 (Regnal. 25 Edw 3 Stat5).

Extradition Act 1870 (33 and 34 Vict. c. 52).

Backing of Warrants (Republic of Ireland) Act 1965 (c 45).

Fugitive Offenders Act 1967 (c. 68).

Criminal Jurisdiction Act 1975 (c. 59).

Suppression of Terrorism Act 1978 (c. 26).

Prevention of Terrorism (Temporary Provisions) Act 1989 (c. 4).

Terrorism Act 2000 (c.11).

\section{United States}

Antiterrorism and Effective Death Penalty Act of 1996, Pub. L. No. 104132, \$443(a), 110 Stat. 1214 (1996).

18 U.S.C. Ch. 209 Extradition $\$ 3181$ (b).

18 U.S.C. Ch. 113B, Part I, $\$ 2331$ (1).

18 U.S.C. Ch. 38 , Title 22 , Annual country reports on terrorism, $\$ 2656$ f.

2 Translated by the author. 


\subsection{Official publications}

Résolutions d'Oxford (Extradition), Justifia et Pace, Institut de Droit International, Session d'Oxford, 9 September 1880.

Révision des articles 13 et 14 des Résolutions d'Oxford (Extradition) Justifia et Pace, Institut de Droit International, Session de Genève, 8 September 1892.

Country Reports on Human Rights Practices for 1991, U.S. Dept. of State, 1031 1394.

107th Congress, 2nd Session, Executive report, Committee on Foreign Relations, 107-13, 21 October 2002.

The Restatement (Fourth) of Foreign Relations Law of the United States: Jurisdiction $\$ 312$, Tentative Draft No 3 (2017).

\subsection{Newspaper articles}

New York Times. 16 August 1981. "I.R.A. member wins extradition case in U.S." http://www.nytimes.com/1981/08/16/nyregion/ira-member-wins-extraditioncase-in-us.html. Retrieved 27 November 2017.

Los Angeles Times. 27 December 1985. "16 die in terrorist attacks at Rome, Vienna airports: 117 hurt in raid aimed at Israeli." http://articles.latimes.com/1985-1227/news/mn-25659_1_rome-airport. Retrieved 31 May 2017.

New York Times. 14 November 2001. "4 guilty in fatal 1986 Berlin disco bombing linked to Libya." http://www.nytimes.com/2001/11/14/world/4-guilty-infatal-1986-berlin-disco-bombing-linked-to-libya.html. Retrieved 14 January 2018.

New York Times. 21 August 2007. "Take Al-Qaeda to court.” http://www.nytimes. com/2007/08/21/opinion/21 moore.html. Retrieved 20 December 2017.

Fox News. 30 November 2010. "Yes, WikiLeaks is a terrorist organization and the time to act is NOW." http://www.foxnews.com/opinion/2010/11/30/yeswikileaks-terrorist-organization-time-act.html. Retrieved 24 April 2017.

The Guardian. 19 December 2010. "Julian Assange like a hi-tech terrorist, says Joe Biden." https://www.theguardian.com/media/2010/dec/19/assange-hightech-terrorist-biden. Retrieved 19 October 2018.

The Guardian. 10 April 2011. "Cuba denounces acquittal of former CIA agent Luis Posada as a farce." https://www.theguardian.com/world/2011/apr/10/luisposada-cuba-denounces-us-acquittal-cia-agent. Retrieved 14 January 2018.

The Irish Independent. 6 May 2012: "Hero or villain? The gruesome tale of the 'real' Playboy of the Western World." http://www.independent.ie/lifestyle/hero-orvillain-the-gruesome-tale-of-the-real-playboy-of-the-western-world-26850686. html. Retrieved 26 September 2017.

The Guardian. 21 August 2013. "Edward Snowden and the NSA files - timeline." https://www.theguardian.com/world/2013/jun/23/edward-snowden-nsafiles-timeline. Retrieved 29 August 2017.

Helsingin Sanomat. 12 August 2014. "Oikeutta käytetään myös sodankäynnin strategiana.” https://www.hs.fi/paakirjoitukset/art-2000002752695.html. Retrieved 10 January 2019.

Reuters. 15 September 2014. "Switzerland would shield Snowden from 'political' extradition to US." https://www.reuters.com/article/us-usa-security-snowdenswitzerland/swiss-say-would-shield-snowden-from-political-extradition-to-u-sidUSKBNOHAIVX20140915. Retrieved 20 November 2017. 
The Guardian. 28 August 2015. "FBI demanded Scandinavian countries arrest Edward Snowden should he visit." https://www.theguardian.com/us-news/2015/aug/28/ edward-snowden-fbi-norway-extradite-julian-assange. Retrieved 24 April 2017.

The Guardian. 25 June 2016: “We thought this would be the end of us': the raid on Entebbe, 40 years on." https://www.theguardian.com/world/2016/ jun/25/entebbe-raid-40-years-on-israel-palestine-binyamin-netanyahu-jonathanfreedland. Retrieved 29 November 2017.

Newsweek. 29 March 2017. "Will Julian Assange be sent to the U.S.? Ecuador election results could decide extradition case." http://www.newsweek.com/julianassange-ecuador-election-wikileaks-576303. Retrieved 24 April 2017.

New York Times Magazine. 12 June 2017. “The long, lonely road of Chelsea Manning.” https://www.nytimes.com/2017/06/12/magazine/the-long-lonely-road-ofchelsea-manning.html. Retrieved 14 January 2018.

New York Times. 18 January 2017. "Russia extends Edward Snowden's asylum." https://www.nytimes.com/2017/01/18/world/europe/edward-snowdenasylum-russia.html. Retrieved 9 May 2018.

Washington Post.27 September 2018. "Theimage ofJulian Assange grows darker by the day." https://www.washingtonpost.com/news/democracy-post/wp/2018/09/27/ the-image-of-julian-assange-grows-darker-by-the-day /?utm_term=. 5 acd7d353406. Retrieved 26 October 2018.

Le Parisien. 14 January 2019. "Battisti arrêté: quel avenir pour les militants italiens qui vivent en France?” http://www.leparisien.fr/faits-divers/battisti-arrete-quelavenir-pour-les-militants-italiens-qui-vivent-en-france-14-01-2019-7988352.php. Retrieved 5 February 2019.

\subsection{Online resources}

Global Terrorism Database: Data Collection Methodology. http://www. stArticleumd.edu/gtd/using-gtd/. Retrieved 23 July 2017.

Merriam Webster. "Depoliticization.” https://www.merriam-webster.com/dictionary/ depoliticization. Retrieved 24 July 2017.

\subsection{Bibliography}

Abbell, Michael. 2010. Extradition to and from the United States 2010. Leiden: Brill Nijhoff.

Aldrich, Richard J. 2004. Transatlantic intelligence and security cooperation. International Affairs 80(4): 731-753.

Allan, Richard. 1993. Terrorism, extradition and international sanctions. Albany Law Journal of Science and Technology 3: 327-341.

Ambos, Kai, and Anina Timmerman. 2014. Terrorism and customary international law. In: Ben Saul (ed.), Research Handbook on International Law and Terrorism. Cheltenham, UK: Edward Elgar, 20-38.

Andreas, Peter, and Ethan Nadelmann. 2006. Policing the Globe: Criminalization and Crime Control in International Relations. Oxford: Oxford University Press.

Angli, Mariona Llobet. 2013. What does 'terrorism' mean? In: Aniceto Masferrer and Clive Walker (eds.), Counter-Terrorism, Human Rights and the Rule of Law: Crossing Legal Boundaries in Defence of the State. Cheltenham, UK and Northampton, MA: Edward Elgar, 17-36. 


\section{Sources and bibliography}

Banoff, Barbara Ann, and Christopher H. Pyle. 1984. "To surrender political offenders": The political offense exception to extradition in United States law. New York University Journal of International Law and Politics 16(2): 169.

Bassiouni, M. Cherif. 1969. Ideologically motivated offences and the political offences exception in extradition: A proposed juridical standard for an unruly problem. De Paul Law Review 19(2): 217-265.

Bassiouni, M. Cherif. 1973. Unlawful seizures and irregular rendition devices as alternatives to extradition. Vanderbilt Journal of Transnational Law 7(1): 25-66.

Bassiouni, M. Cherif. 1987. A Draft International Criminal Code and Draft Statute for an International Criminal Tribunal. Rev. ed. Dordrecht: Nijhoff.

Bassiouni, M. Cherif. 2001. International Terrorism: Multilateral Conventions (1937-2001). Ardsley, NY: Transnational Publishers.

Bassiouni, M. Cherif. 2002. International Terrorism: A Compilation of U.N. Documents 1972-2001, vol. 1. International and Comparative Criminal Law Series. Ardsley, NY: Transnational Publishers.

Bassiouni, M. Cherif, and Edward M. Wise. 1995. Aut Dedere Aut Judicare: The Duty to Extradite or Prosecute in International Law. Dordrecht: Nijhoff.

Basso, Kathleen A. 1989. The 1985 U.S.-U.K. Supplementary extradition treaty: A superfluous effort? Boston College International and Comparative Law Review 12(1): 301 .

Bay, Christian. 1989. Civil disobedience: The inner and outer limits. In: C.E.S. Franks (ed.), Dissent and the State. Oxford: Oxford University Press, 40-61.

De Benedictis, Angela. 2001. Politica, governo e istituzioni nell'Europa moderna. Bologna: Il mulino.

Berger, Stefan. 2006. A Companion to Nineteenth-Century Europe, 1789-1914. Malden, MA: Blackwell.

Bingham, Lord of Cornhill. 2006. Rule of Law. Sixth Sir David Williams Lecture. 16 November. https://www.cpl.law.cam.ac.uk/sir-david-williams-lectures2006rule-law/rule-law-text-transcript. Retrieved 2 May 2018.

Blakesley, Christopher L. 1981. The practice of extradition from antiquity to modern France and the United States: A brief history. Boston College International and Comparative Law Review 4(1): 39-60.

Blakesley, Christopher L. 1986. The evisceration of the political offense exception to extradition. Denver Journal of International Law and Policy 15(1): 109.

Blakesley, Christopher L. 2000. Autumn of the patriarch: The Pinochet extradition debacle and beyond: Human rights clauses compared to traditional derivative protections such as double criminality. The Journal of Criminal Law and Criminology 91(1): 1-98.

Blakesley, Christopher L. 2002. The United States. In: Albin Eser, Otto Lagodny, and Christopher L. Blakesley (eds.), The Individual as Subject of International Cooperation: A Comparative Study. Baden-Baden, Germany: Nomos, 527-695.

Boister, Neil. 2015. The concept and nature of transnational criminal law. In: Neil Boister and Robert J. Currie (eds.), Routledge Handbook of Transnational Criminal Law. London: Routledge/Taylor \& Francis Group, 11-26.

Boister, Neil, and Robert J. Currie (eds.) 2015. Routledge Handbook of Transnational Criminal Law. London: Routledge/Taylor \& Francis Group.

Borelli, Silvia. 2014. Extraordinary rendition, counterterrorism and international law. In: Ben Saul (ed.), Research Handbook on International Law and Terrorism. Cheltenham, UK: Edward Elgar, 361-378. 
Borum, Randy, and Chuck Tilby. 2005. Anarchist direct actions: A challenge for law enforcement. Studies in Conflict and Terrorism 28(3): 201-223.

Boyd, Colin. 26-30 August 2001. Workshop: Police investigations of "politically sensitive" or high profile crimes: The Lockerbie trial. Paper presented at International Society for the Reform of Criminal Law, 15th International Conference: Politics, Crime and Criminal Justice. Canberra, Australia.

Bribosia, Emmanuelle, and Anne Weyembergh. 1997. Asile et extradition: Vers un espace judiciaire européen. Revue Belge de Droit International 30(1): 69-132.

Bryan, Dominic. 2012. Is terrorism still a useful analytical term or should it be abandoned? NO: A landscape of meaning: Constructing understandings of political violence from the broken paradigm of terrorism. In: Richard Jackson and Samuel J. Sinclair (eds.), Contemporary Debates on Terrorism. Abingdon, Oxon, UK: Routledge, 17-25.

Buller, Jim, and Matthew Flinders. 2005. Depoliticization, democracy and arenashifting. Paper presented at Autonomisation of the State: From Integrated Administrative Models to Single Purpose Organizations, SCANCOR/SOG Conference. Stanford University.

Cancio Melia, Manuel, and Anneke Petzsche. 2013. Terrorism as a criminal offence. In Aniceto Masferrer (ed.), Counter-Terrorism, Human Rights and the Rule of Law: Crossing Legal Boundaries in Defence of the State. Cheltenham, UK, and Northampton, MA: Edward Elgar, 87-105.

Carbonneau, Thomas E. 1980. Terrorist acts - crimes or political infractions? An appraisal of recent French extradition cases. Hastings International and Comparative Law Review 3(2): 265.

Carbonneau, Thomas E. 1983. The political offense exception as applied in French cases dealing with the extradition of terrorists: The quest for an appropriate doctrinal analysis revisited. Michigan Yearbook of International Legal Studies 209-243.

Casale, David. 2008. EU institutional and legal counter-terrorism framework. Defence Against Terrorism Review 1(1): 49-78.

Cassese, Antonio. 1989. Terrorism, Politics and Law: The Achille Lauro Affair. Cambridge: Polity Press.

Cassese, Antonio. 2001. Terrorism is also disrupting some crucial legal categories of international law. European Journal of International Law 12(5): 993-1001.

Clark, Reuben J. Jr. 1909. Address of Mr. J. Reuben Clark, Jr., assistant solicitor of the Department of State. [The nature definition of political offense in international extradition]. Proceedings of the American Society of International Law at its Annual Meeting (1907-1917) 3: 95-165.

Coady, C. A. J. 2008. Morality and Political Violence. Cambridge and New York: Cambridge University Press.

Cohen, Aviv. 2012. Prosecuting terrorists at the international criminal court: Reevaluating and unused legal tool to combat terrorism. Michigan State International Law Review 20(2): 219-257.

Collyer, Michael. 2005. Secret agents: Anarchists, Islamists and responses to politically active refugees in London. Ethnic and Racial Studies 28 (2): 278-303.

Corrado, Raymond R., and Rebecca Evans. 1988. Ethnic and ideological terrorism in Western Europe. In: Michael Stohl (ed.), The Politics of Terrorism, 3rd ed. New York: Marcel Dekker, 373-444. 


\section{Sources and bibliography}

Coudert, Frederic R. 1909. Address of Mr. Frederic R. Coudert, of New York City. [The nature definition of political offense in international extradition]. Proceedings of the American Society of International Law at its Annual Meeting (1907-1917) 3: 95-165.

Coudert, Frederic R., Julian W. Mack, and Reuben J. Clark. 1909. The nature definition of political offense in international extradition. Proceedings of the American Society of International Law at its Annual Meeting (1907-1917) 3: 95-165.

Currie, Robert J. 2015. The protection of human rights in the suppression of transnational crime. In: Neil Boister and Robert J. Currie (eds.), Routledge Handbook of Transnational Criminal Law. London: Routledge/Taylor \& Francis Group, 27-40.

Deen-Racsmány, Zsuzsanna. 2007. Active personality and non-extradition of nationals in international criminal law at the dawn of the twenty-first century: Adapting key functions of nationality to the requirements of International Criminal Justice. Doctoral thesis, Leiden University.

Deere, Lora L. 1933. Political offenses in the law and practice of extradition. The American Journal of International Law 27(2): 247-270.

DeFabo, Vincent. 2012. Terrorist or revolutionary: The development of the political offender exception and its effects on defining terrorism in international law. American University National Security Law Brief 2(2): 69-104.

Deflem, Mathieu. 2002. Policing World Society: Historical Foundations of International Police Cooperation. Clarendon Studies in Criminology. Oxford: Oxford University Press.

Deflem, Mathieu. 2004. Social control and the policing of terrorism: Foundations for a sociology of counter-terrorism. The American Sociologist 35(2): 75-92.

Deflem, Mathieu. 2005. "Wild beasts without nationality": The uncertain origins of Interpol 1898-1910. In: Philip L. Reichel (ed.), The Handbook of Transnational Crime and Justice. Thousand Oaks, CA: Sage, 275-285.

Deflem, Mathieu. 2006. Global rule of law or global rule of law enforcement? International police cooperation and counter-terrorism. The Annals of the American Academy of Political and Social Science 603: 240-251.

DeSchutter, Bart. 1975. Problems of jurisdiction in the international control and repression of terrorism. In: M. Cherif Bassiouni (ed.) International Terrorism and Political Crimes. Springfield, IL: Charles C. Thomas, 377-390.

Dickson, Brice. 2013. The right of access to a lawyer in terrorist cases. In: Aniceto Masferrer and Clive Walker (eds.), Counter-Terrorism, Human Rights and the Rule of Law: Crossing Legal Boundaries in Defence of the State. Cheltenham, UK, and Northampton, MA: Edward Elgar, 189-211.

Di Filippo, Marcello. 2014. The definition(s) of terrorism in international law. In: Ben Saul (ed.), Research Handbook on International Law and Terrorism. Cheltenham, UK: Edward Elgar 3-19.

Di Paola, Pietro. 2007. The spies who came in from the heat: The international surveillance of the anarchists in London. European History Quarterly 37(2): 189-215.

Ditrych, Ondrej. 2013. From discourse to dispositif: States and terrorism between Marseille and 9/11. Security Dialogue 44(3): 223-240.

Dugard, John. 1973. Towards the definition of international terrorism. The American Journal of International Law 67(5): 94-100.

Dugard, John, and Christine van den Wijngaert. 1998. Reconciling extradition with human rights. The American Journal of International Law 92(2): 187-212. 
Dumitriu, Eugenia. 2004. The EU's definition of terrorism: The council framework decision on combating terrorism. German Law Journal 5(5): 585-602.

Duyvesteyn, Isabelle. 2004. How new is the new terrorism? Studies in Conflict and Terrorism 27(5): 439-454.

Emerson, Steve. 2004. The Lockerbie terrorist attack and Libya: A retrospective analysis. Case Western Reserve Journal of International Law 36(2/3): 487-490.

Epps, Valerie. 1979. The validity of the political offender exception in extradition treaties in Anglo-American jurisprudence. Harvard International Law Journal 6l(20): 61-88.

Epps, Valerie. 1988. Abolishing the political offence exception. In: M. Cherif Bassiouni (ed.), Legal Responses to International Terrorism: U.S. Procedural Aspects, vol. 4. Dordrecht: Martinus Nijhoff, 203-217.

Eser, Albin, Otto Lagodny, and Christopher L. Blakesley. 2002. The Individual as Subject of International Cooperation: A Comparative Study. Baden-Baden, Germany: Nomos.

Evans, Alona E. 1969. The political refugee in United States immigration law and practice. International Lawyer 3(2): 204-253.

Extradition. 1935. American Journal of International Law Supplement 29(1): 1-1240.

Ferrari, Robert. 1920. Political crime. Columbia Law Review 20(3): 308-316.

Field, David Dudley. 1876. Outlines of an International Code, 2nd ed. New York: Baker, Voorhis \& Co.

Fields, Louis. 1988. The evolution of U.S. counter-terrorist policy. In: M. Cherif Bassiouni (ed.), Legal Responses to International Terrorism: U.S. Procedural Aspects, vol. 4. Dordrecht: Martinus Nijhoff, 279-288.

Flemming, Peter A., Alex P. Schmid, and Michael Stohl. 1988. The theoretical utility of typologies of terrorism: Lessons and opportunities. In: Michael Stohl (ed.), The Politics of Terrorism, 3rd ed. New York: Marcel Dekker, 153-195.

Fletcher, George P. 2006. The indefinable concept of terrorism. Journal of International Criminal Justice 4(5): 894-911.

Fooner, Michael. 1989. Interpol: Issues in World Crime and International Criminal Justice. New York: Plenum.

Franks, C.E.S. 1989. Dissent and the State. Toronto: Oxford University Press.

Freestone, David. 1981. Legal responses to terrorism: Towards European cooperation. In Juliet Lodge (ed.), Terrorism: A Challenge to the State. Oxford: Martin Robertson, 195-224.

Friedlander, Robert A. 1988. The U.S. legislative approach. In: M. Cherif Bassiouni (ed.), Legal Responses to International Terrorism: U.S. Procedural Aspects, vol. 4. Dordrecht: Martinus Nijhoff, 3-23.

Fukuyama, Francis. 1992. The End of History and the Last Man. New York: The Free Press.

Galgani, Benedetta. 2013. Extradition, political offence and the discrimination clause. In: Stefano Ruggeri (ed.), Transnational Inquiries and the Protection of Fundamental Rights in Criminal Proceedings: A Study in Memory of Vittorio Grevi and Giovanni Tranchina. Berlin: Springer, 167-191.

Galli, Francesca. 2013. Freedom of thought or "thought-crimes"? Counter-terrorism and freedom of expression. In: Aniceto Masferrer and Clive Walker (ed.) CounterTerrorism, Human Rights and the Rule of Law: Crossing Legal Boundaries in Defence of the State. Cheltenham, UK, and Northampton, MA: Edward Elgar, 106-127. 
Ganor, Boaz, and Alex Conte. 2005. Legal and Policy Issues in Establishing an International Framework for Human Rights Compliance When Countering Terrorism. International Institute for Counter-Terrorism.

García-Mora, Manuel R. 1956. International Law and Asylum as a Human Right. Washington, DC: Public Affairs Press.

García-Mora, Manuel R. 1962. The nature of political offenses: A knotty problem of extradition law. Virginia Law Review 48(7): 1226-1257.

Gemie, Sharif, 2006. Revolutions and revolutionaries: Histories, concepts and myths. In: Stefan Berger (ed.), A Companion to Nineteenth-Century Europe, 1789-1914. Malden, MA: Blackwell, 125-137.

Gilbert, Geoff. 1985. Terrorism and the political offence exemption reappraised. The International and Comparative Law Quarterly 34(4): 695-723.

Gilbert, Geoff. 1991. Aspects of Extradition Law: International Studies in Human Rights. Dordrecht: Nijhoff.

Gilbert, Geoff. 1998. Transnational Fugitive Offenders in International Law: Extradition and Other Mechanisms. The Hague: Martinus Nijhoff.

Gilbert, Geoff. 2014. Terrorism and international refugee law. In: Ben Saul (ed.), Research Handbook on International Law and Terrorism. Cheltenham, UK: Edward Elgar, 470-485.

Gilmore, William C. 1992. Extradition and the political offence exception: Reflections on United Kingdom law and practice. Commonwealth Law Bulletin 18(2): 701-719.

Gold, Martin E. 1970. Non-extradition for political offenses: The communist perspective. Harvard International Law Journal 11(1): 191.

Grace, Elizabeth, and Colin Leys. 1989. The concept of subversion and its implications. In: C.E.S. Franks (ed.), Dissent and the State. Toronto: Oxford University Press, 62-85.

Green, L.C. 1962. Political offences, war crimes and extradition. The International and Comparative Law Quarterly 11(2): 329-354.

Groarke, John Patrick. 1988. Revolutionaries beware: The erosion of the political offense exception under the 1986 United States-United Kingdom supplementary extradition treaty. University of Pennsylvania Law Review 136(5): 1515-1545.

Gurr, Ted Robert. 1988. Some characteristics of political terrorism in the 1960s. In: Michael Stohl (ed.), The Politics of Terrorism, 3rd ed. New York: Marcel Dekker, 31-57.

Gustavsson, Gina. 2014. Romantic liberalism: An alternative perspective on liberal disrespect in the Muhammad cartoons controversy. Political Studies 62(1): 53-69.

Hagan, Frank E. 1997. Political Crime: Ideology and Criminality. Needham Heights, MA: Allyn \& Bacon.

Hallberg, Pekka. 2004. The Rule of Law. Helsinki, Finland: Edita.

Hannay, William M. 1988. The legislative approach to the political offence exception. In: M. Cherif Bassiouni (ed.), Legal Responses to International Terrorism: U.S. Procedural Aspects, vol. 4. Dordrecht: Martinus Nijhoff, 115-127.

Harrington, Joanna. 2015. Extradition of transnational criminals. In: Neil Boister and Robert J. Currie (eds.), Routledge Handbook of Transnational Criminal Law. London: Routledge/Taylor \& Francis Group, 153-166.

Hebenton, Bill, and Terry Thomas. 1995. Policing Europe: Co-operation, Conflict and Control. New York: St. Martin's Press.

Held, David. 1995. Democracy and the Global Order: From the Modern State to Cosmopolitan Governance. Cambridge: Polity Press. 
Herbst, Philip. 2003. Talking Terrorism: A Dictionary of the Loaded Language of Political Violence. Westport, CT: Greenwood Press.

Hessick, Carissa Byrne. 2006. Motive's role in criminal punishment. Southern California Law Review 80: 89-150.

Himmelstrand, Ulf. 1961. A Theoretical and Empirical Approach to the Study of Depoliticization and Political Involvement. Uppsala, Sweden: Research Reports from the Department of Sociology, Uppsala University.

Hobsbawm, Eric John. 1962. The Age of Revolution: Europe 1789-1848. London: Weidenfeld \& Nicolson.

Hoffman, Bruce. 1998. Inside Terrorism. London: Victor Gollancz.

Husak, Douglas N. 1989. Motive and criminal liability. Criminal Justice Ethics 8(1): $3-14$.

Ingraham, Barton L., and Kazuhiko Tokoro. 1969. Political crime in the United States and Japan. Issues in Criminology 4(2): 145-169.

Jackson, Freedom, Kelly R. Damphousse, and Brent L. Smith. 2002. The prosecution and punishment of international terrorists in federal courts: 1980-1998. Criminology and Public Policy 1(3): 311-388.

Jansson, Julia. 2008. Different centuries, similar responses? International police cooperation and the depoliticizing of terrorism in 1898 and 1998. Unpublished master's thesis, University of Helsinki, Finland.

Jenkins, Philip. 2003. Images of Terror: What We Can and Can't Know about Terrorism. New York: Aldine de Gruyter.

Jensen, Richard Bach. 1981. The international anti-anarchist conference of 1898 and the origins of Interpol. Journal of Contemporary History 16(2): 323-347.

Jensen, Richard Bach. 2014. The Battle against Anarchist Terrorism: An International History, 1878-1934. New York: Cambridge University Press.

Kälin, Walter, and Jorg Künzli. 2000. Article 1F: Freedom fighters, terrorists, and the notion of serious non-political crimes. International Journal of Refugee Law 46(12): 47-78.

Kaufman, Whitley R.P. 2003. Motive, intention, and morality in the criminal law. Criminal Justice Review 28(2): 317-335.

Kaunert, Christian. 2010. Europol and EU counterterrorism: International security actorness in the external dimension. Studies in Conflict and Terrorism 33(7): 652-671.

Kekkonen, Jukka. 2013. Mitä on kontekstuaalinen oikeushistoria? Helsinki: Helsingin yliopisto.

Kinna, Ruth (ed.). 2006. Early Writings on Terrorism, vols. 1-3. London and New York: Routledge.

Kirchheimer, Otto. 1961. Political Justice. The Use of Legal Procedure for Political Ends. Princeton, NJ: Princeton University Press.

Klabbers, Jan. 2003. Rebel with a cause? Terrorists and humanitarian law. European Journal of International Law 14(2): 299-312.

Knauss, Peter R., and D. A. Strickland 1988. Political disintegration and latent terror. In: Michael Stohl (ed.), The Politics of Terrorism, 3rd ed. New York: Marcel Dekker, 85-125.

Kulman, Bradley G. 1986. Eliminating the political offense exception for violent crimes: The proposed United States-United Kingdom supplementary extradition treaty. Virginia Journal of International Law 26(3): 755.

Kundnani, Arun. 2012. Radicalisation: The journey of a concept. Race and Class 54(2): 3-25. 
Lanzoni, Monica. 2017. Les exilés politiques italiens et la Doctrine Mitterrand: Le juridique, le politique et l'asile français. Viaggiatori 1(1): 187-223.

Levi, Michael. 2007. Organized crime and terrorism. In: Mike Maguire, Rod Morgan, and Robert Reiner (eds.), The Oxford Handbook of Criminology, 4th ed. Oxford: Oxford University Press, 771-809.

Li, Yao. 2017. Exclusion from Protection as a Refugee: An Approach to a Harmonizing Interpretation in International Law. Boston and Leiden: Brill Nijhoff.

Liang, Hsi-Huey. 1992. The Rise of Modern Police and the European State System from Metternich to the Second World War. Cambridge, UK: Cambridge University Press.

Lieberman, David M. 2006. Sorting the revolutionary from the terrorist: The delicate application of the "political offense" exception in U.S. extradition cases. Stanford Law Review 59(1): 181-212.

Lodge, Juliet. 1981a. Concluding remarks. In: Juliet Lodge (ed.), Terrorism: A Challenge to the State. Oxford: Martin Robertson, 225-230.

Lodge, Juliet. 1981b. The European community and terrorism: Establishing the principle of 'extradite or try'. In: Juliet Lodge (ed.), Terrorism: A Challenge to the State. Oxford: Martin Robertson, 91-194.

Lodge, Juliet. 1981c. Terrorism: A Challenge to the State. Oxford, UK: Martin Robertson.

Lubet, Steven. 1982. Extradition reform: Executive discretion and judicial participation in the extradition of political terrorists. Cornell International Law Journal 15(2): 247-291.

Lundestad, Geir. 2003. The United States and Western Europe Since 1945: From "Empire" by Invitation to Transatlantic Drift. Oxford: Oxford University Press.

Maguire, Mike, Rod Morgan, and Robert Reiner (eds.). 2007. The Oxford Handbook of Criminology, 4th ed. Oxford: Oxford University Press.

McDermott, Helen. 2015. The structure of international cooperation in the transfer of suspects. Extradite or abduct? International Criminal Law Review 15(2): 254-297.

McElrath, Karen. 2000. Unsafe Haven: The United States, the IRA, and Political Prisoners. London: Pluto Press.

Mettraux, Guénaël. 2014. The United Nations special tribunal for Lebanon: Prosecuting terrorism. In: Ben Saul (ed.), Research Handbook on International Law and Terrorism, Cheltenham, UK: Edward Elgar 651-665.

Meysman, Michaël. 2016. Belgium and the European arrest warrant: Is European criminal cooperation under pressure? European Criminal Law Review 6(2): $186-210$.

Müller-Rappard, Ekkerhart. 1988. The European response to international terrorism. In M. Cherif Bassiouni (ed.), Legal Responses to International Terrorism: U.S. Procedural Aspects, vol. 4. Dordrecht: Martinus Nijhoff, 385-417.

Mulligan, William. 2006. Restrained competition: International relations. In: Berger, Stefan (ed.), A Companion to Nineteenth-Century Europe, 1789-1914. Malden, MA: Blackwell, 403-416.

Murphy, John F. 1985. Punishing International Terrorists: The Legal Framework for Policy Initiatives. Totowa, NJ: Rowman \& Allanheld.

Nadelmann, Ethan A. 1993. The evolution of United States involvement in the international rendition of fugitive criminals. New York University Journal of International Law and Politics 25(4): 813-885. 
Nicholson, Frances, and Patrick Twomey (eds.). 1999. Refugee Rights and Realities: Evolving International Concepts and Regimes. Cambridge: Cambridge University Press.

Noone, Michael F., and Yonah Alexander. 1997. Cases and Materials on Terrorism: Three Nations' Response. The Hague: Kluwer Law International.

Norton Moore, John. 1988. The need for an international convention. In: M. Cherif Bassiouni (ed.), Legal Responses to International Terrorism: U.S. Procedural Aspects, vol. 4. Dordrecht: Martinus Nijhoff, 437-444.

Nuotio, Kimmo. 2006. Terrorism as a catalyst for the emergence, harmonization and reform of criminal law. Journal of International Criminal Justice 4(5): 998-1016.

Oehmichen, Anna. 2009. Terrorism and Anti-Terror Legislation: The Terrorised Legislator? A Comparison of Counter-Terror Legislation and Its Implications on Human Rights in the Legal Systems of the United Kingdom, Spain, Germany and France. School of Human Rights Research Series, vol. 34. Antwerp: Intersentia.

Oppenheim, Lassa, Robert Jennings, and Arthur Watts. 1992. Oppenheim's International Law. Vol. 1: Peace, parts 2 to 4, 9th ed. London: Longman.

Patterson, James T. 2005. Restless Giant: The United States from Watergate to Bush v. Gore. New York: Oxford University Press.

Perry, Gregory Chadwick. 1989. The four major Western approaches to the political offense exception to extradition: From inception to modern terrorism. Mercer Law Review 40(2): 709.

Petersen, Antje C. 1992. Extradition and the political offence exception in the suppression of terrorism. Indiana Law Journal 67(3): 767-796.

Piemonte, Christina. 2013. Motivation is fickle in the application of the political offense exception to extradition. Tulane Journal of International and Comparative Law 21(2): 617-633.

Plachta, Michael. 1999. (Non-)extradition of nationals: A neverending story. Emory International Law Review 77(13): 77-159.

Puistola, Juha-Antero, and Janne Herrala. 2006. Terrorismi Euroopassa: Terrorismi äärimmäisen poliittisen, taloudellisen ja kulttuurillisen turhautumisen ilmentymänä. Helsinki: Tammi.

Pyle, Christopher H. 1988. The political offence exception. In: M. Cherif Bassiouni (ed.), Legal Responses to International Terrorism: U.S. Procedural Aspects, vol. 4. Dordrecht: Martinus Nijhoff, 115-127.

Pyle, Christopher H. 2001. Extradition, Politics and Human Rights. Philadelphia, PA: Temple University Press.

Rogers, David M. 2003. International law - extradition and the political offense exception. Suffolk Transnational Law Review 26(2): 479.

Ronen, Yaël. 2014. Terrorism and freedom of expression in international law. In: Ben Saul (ed.), Research Handbook on International Law and Terrorism. Cheltenham, UK: Edward Elgar, 437-452.

Ross, Jeffrey Ian. 2003. The Dynamics of Political Crime. Thousand Oaks, CA: Sage . Ross, Jeffrey Ian. 2012. An Introduction to Political Crime. Bristol, UK: Policy Press. Said, Wadie E. 2012. The message and means of the modern terrorism prosecution. (Ten years after 9/11: Rethinking counterterrorism). Transnational Law and Contemporary Problems 21(1): 175-196.

Said, Wadie E. 2015. Crimes of Terror. The Legal and Political Implications of Federal Terrorism Prosecutions. Oxford: Oxford University Press. 
Sambei, Arvinder, Anton Du Plessis, and Martin Polaine. 2009. Counter-Terrorism Law and Practice: An International Handbook. Oxford and New York: Oxford University Press.

Sapiro, Miriam E. 1986. Extradition in an era of terrorism: The need to abolish the political offense exception. New York University Law Review 61(4): 654.

Saul, Ben. 2005. Attempts to define 'terrorism' in international law. Netherlands International Law Review 52(1): 57-83.

Saul, Ben. 2006. The legal response of the League of Nations to terrorism. Journal of International Criminal Justice 4(1): 78-102.

Saul, Ben. 2008. The curious element of motive in definitions of terrorism: Essential ingredient - or criminalising thought? Sydney Law School, Research Paper No. $08 / 123$.

Saul, Ben. 2011. Documents in International Law: Terrorism. Oxford: Hart.

Saul, Ben. 2012. Terrorism. Oxford: Hart.

Saul, Ben. 2014a. International convention against the taking of hostages. United Nations Audiovisual Library of International Law.

Saul, Ben (ed.). 2014b. Research Handbook on International Law and Terrorism. Cheltenham, UK: Edward Elgar .

Saul, Ben. 2014c. Terrorism and international humanitarian law. In: Ben Saul (ed.), Research Handbook on International Law and Terrorism. Cheltenham, UK: Edward Elgar, 208-231.

Saul, Ben. 2015. Terrorism as a transnational crime. In: Neil Boister and Robert J. Currie (eds.), Routledge Handbook of Transnational Criminal Law. London: Routledge/Taylor \& Francis Group, 394-408.

Schafer, Stephen. 1971. The concept of the political criminal. The Journal of Criminal Law, Criminology and Police Science 62(3): 380-387.

Schlaefer, Cindy Verne. 1981. American courts and modern terrorism: The politics of extradition. New York University Journal of International Law and Politics 13(3): 617.

Schmid, Alex P. 1984. Political Terrorism: A Research Guide to Concepts, Theories, Databases and Literature. C.O.M.T. publication no. 12. Amsterdam: North-Holland.

Schmid, Alex P. 2004. Terrorism - the definitional problem. Case Western Reserve Journal of International Law 36(2-3): 375.

Schmid, Alex P. 2011. The Routledge Handbook of Terrorism Research. Routledge Handbooks. London: Routledge.

Schmitt, Carl. 1996 (orig. 1932). The Concept of the Political. Translated and Introduction by George Schwab. Foreword by Tracy B. Strong. Notes by Leo Strauss. Chicago: University of Chicago Press.

Schwab, George. 1996. Introduction. In: Carl Schmitt, The Concept of the Political. Chicago: University of Chicago Press, 3-16.

Shearer, Ivan Anthony. 1966. Non-extradition of nationals. The Adelaide Law Review 2(3): 273-309.

Shearer, Ivan Anthony. 1971. Extradition in International Law. Manchester, UK: Manchester University Press.

Sheehan, Seán M. 2003. Anarchism. London: Reaktion Books.

Shklar, Judith N. 1986. Legalism: Law, Morals, and Political Trials. Cambridge, MA: Harvard University Press. 
Sievers, Julia. 2008. Too different to trust? First experiences with the application of the European arrest warrant. In: Elspeth Guild and Florian Geyer (eds.), Security Versus Justice? Police and Judicial Cooperation in the European Union. Abingdon, Oxon, UK: Ashgate, 109-128.

Smith, Brent L., and Kelly R. Damphousse. 1996. Punishing political offenders: The effect of political motive on federal sentencing decisions. Criminology 34(3): 289-322.

Sofaer, Abraham D. 1986. The political offense exception and terrorism. (United States, Great Britain). Denver Journal of International Law and Policy 15(1): 125.

Spear, Samuel T. 1983 (orig. 1885). The Law of Extradition, International and InterState, 3rd ed. Littleton, CO: F.B. Rothman.

Stanbrook, Ivor, and Clive Stanbrook. 2000. Extradition: Law and Practice. Oxford: University Press.

Steinbock, Daniel J. 1999. The refugee definition as law: Issues of interpretation. In: Frances Nicholson and Patrick Twomey (eds.), Refugee Rights and Realities: Evolving International Concepts and Regimes. Cambridge: Cambridge University Press, 13-36.

Stohl, Michael. 1988a. Demystifying terrorism: The myths and realities of contemporary political terrorism. In: Michael Stohl (ed.), The Politics of Terrorism, 3rd ed. New York:Marcel Dekker, 1-28.

Stohl, Michael. 1988b. The Politics of Terrorism, 3rd ed. Public Administration and Public Policy, 33. New York: Marcel Dekker.

Stohl, Michael. 1988c. Responding to the terrorist threat: Fashions and fundamentals. In: Michael Stohl (ed.), The Politics of Terrorism, 3rd ed. New York: Marcel Dekker, 579-599.

Strauss, Leo. 1996. Notes on Carl Schmitt: The concept of the political. In: Carl Schmitt Schwab, The Concept of the Political. Chicago: University of Chicago Press, 81-107.

Strong, Tracy B. 1996. Foreword: Dimensions of the new debate around Carl Schmitt. In: Carl Schmitt, The Concept of the Political. Chicago: University of Chicago Press, ix-xxvii.

Sztucki, Jerzy. 1999. Who is a refugee? The convention definition: Universal or obsolete? In: Frances Nicholson and Patrick Twomey (eds.), Refugee Rights and Realities: Evolving International Concepts and Regimes. Cambridge: Cambridge University Press, 55-80.

Tamburini, Francesco. 1997. La conferenza internazionale di roma per la difesa sociale contro gli anarchici (24 novembre-21 dicembre 1898). Clio: Rivista Trimestrale Di Studi Storici (2).

Targ, Harry R. 1988. Societal structure and revolutionary terrorism: A preliminary investigation. In: Michael Stohl (ed.), The Politics of Terrorism, 3rd ed. New York: Marcel Dekker, 127-151.

Teitel, Ruti G. 2000. Transitional Justice. Oxford and New York: Oxford University Press.

Tilly, Charles. 2002. Violence, terror, and politics as usual. America's "new war" reflects an epochal change in the nature of collective violence. Boston Review 27: 3-4.

Tilly, Charles. 2003. The Politics of Collective Violence. Cambridge Studies in Contentious Politics. Cambridge: Cambridge University Press. 


\section{Sources and bibliography}

Trager, Oliver. 1986. Fighting Terrorism: Negotiation or Retaliation? New York: Facts on File.

Tuchman, Barbara Wertheim. 1966. The Proud Tower: A Portrait of the World before the War 1890-1914. New York: Macmillan.

Turner, Stephen. 1989. Depoliticizing power. (Review of Barry Barnes, The Nature of Power). Social Studies of Science 19(3): 533.

Vallée, Charles. 1976. La convention européenne pour la répression du terrorisme. Annuaire Français De Droit International 22(1): 756-786.

Van de Wijngaert, Christine. 1980. The Political Offence Exception to Extradition: The Delicate Problem of Balancing the Rights of the Individual and the International Public Order. Deventer: Amsterdam.

Vedel, Georges (ed.) 1962. La dépolitisation: Mythe ou réalitée. Paris: Collin.

Walker, Clive. 1992. The Prevention of Terrorism in British Law, 2nd ed. Manchester, UK: Manchester University Press.

Wallerstein, Shlomit. 2013. Safety interviews, adverse inferences and the relationship between terrorism and ordinary criminal law. In: Aniceto Masferrer and Clive Walker (eds.), Counter-Terrorism, Human Rights and the Rule of Law: Crossing Legal Boundaries in Defence of the State. Cheltenham, UK, and Northampton, MA: Edward Elgar, 149-165.

Wight, Colin. 2015. Rethinking Terrorism: Terrorism, Violence and the State. London: Palgrave McMillan.

Wilkinson, Paul. 2012. Is terrorism still a useful analytical term or should it be abandoned? YES: The utility of the concept of terrorism. In: Richard Jackson and Samuel J. Sinclair (eds.), Contemporary Debates on Terrorism. Abingdon, Oxon, UK: Routledge, 12-17.

Wouters, Jan, and Frederik Naert. 2004. Of arrest warrants, terrorist offences and extradition deals: An appraisal of the EU's main criminal law measures against terrorism after "11 September." Common Market Law Review 41(4): 909-935.

Wright, Richard A., and J. Mitchell Miller (eds.). 2005. Encyclopedia of Criminology, vol. 2. New York: Routledge.

Young, Reuven. 2006. Defining terrorism: The evolution of terrorism as a legal concept in international law and its influence on definitions in domestic legislation. Boston College International and Comparative Law Review 29(1): 23.

Zanotti, Isidoro. 2006. Extradition in Multilateral Treaties and Conventions. Leiden: Brill. 


\section{Appendix}

\section{Table on US extradition treaties}

The following table contains those provisions of US extradition treaties that relate to political crime and terrorism. The table consists of 119 treaties dating from 1842 until 2007. 


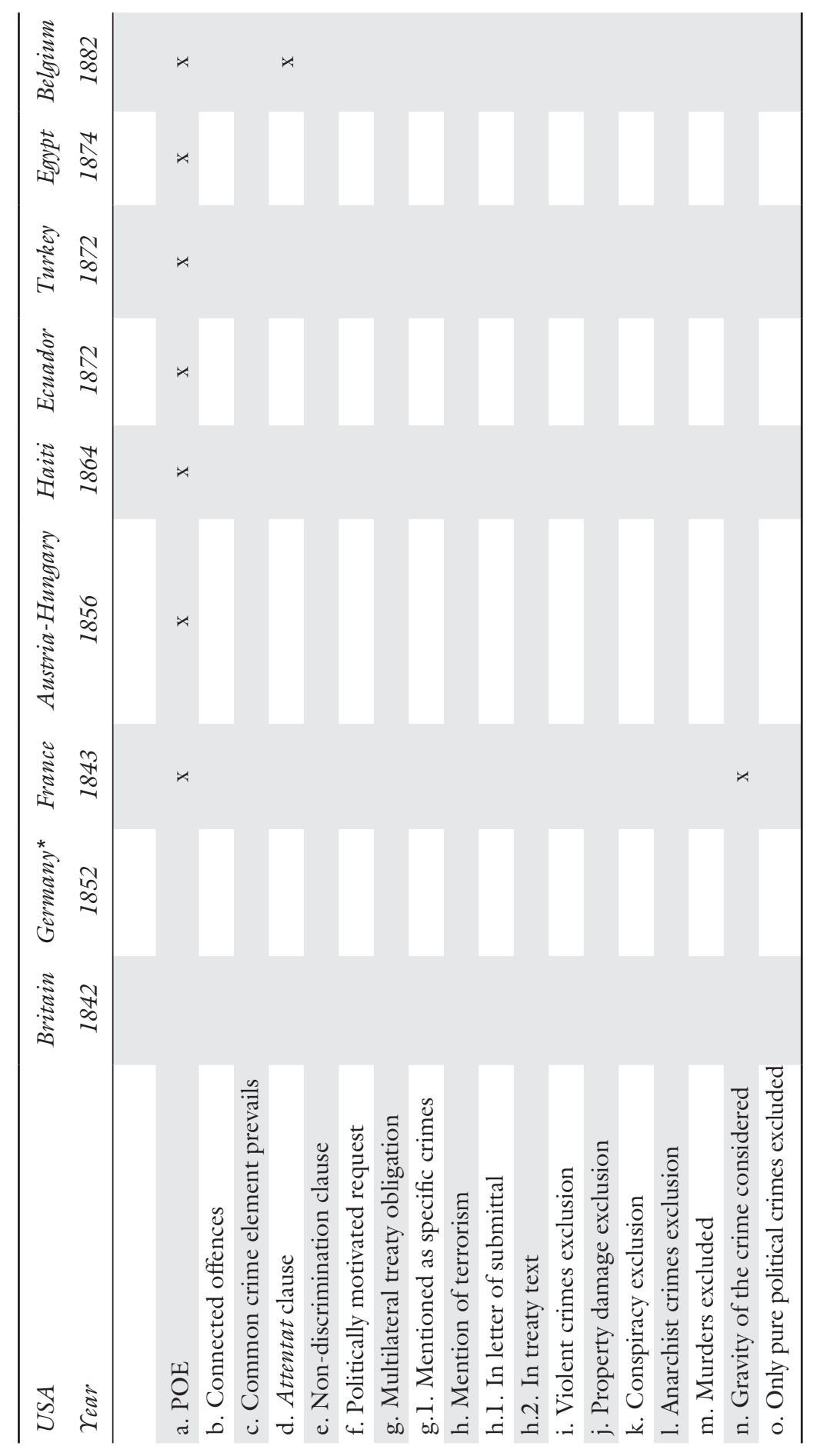




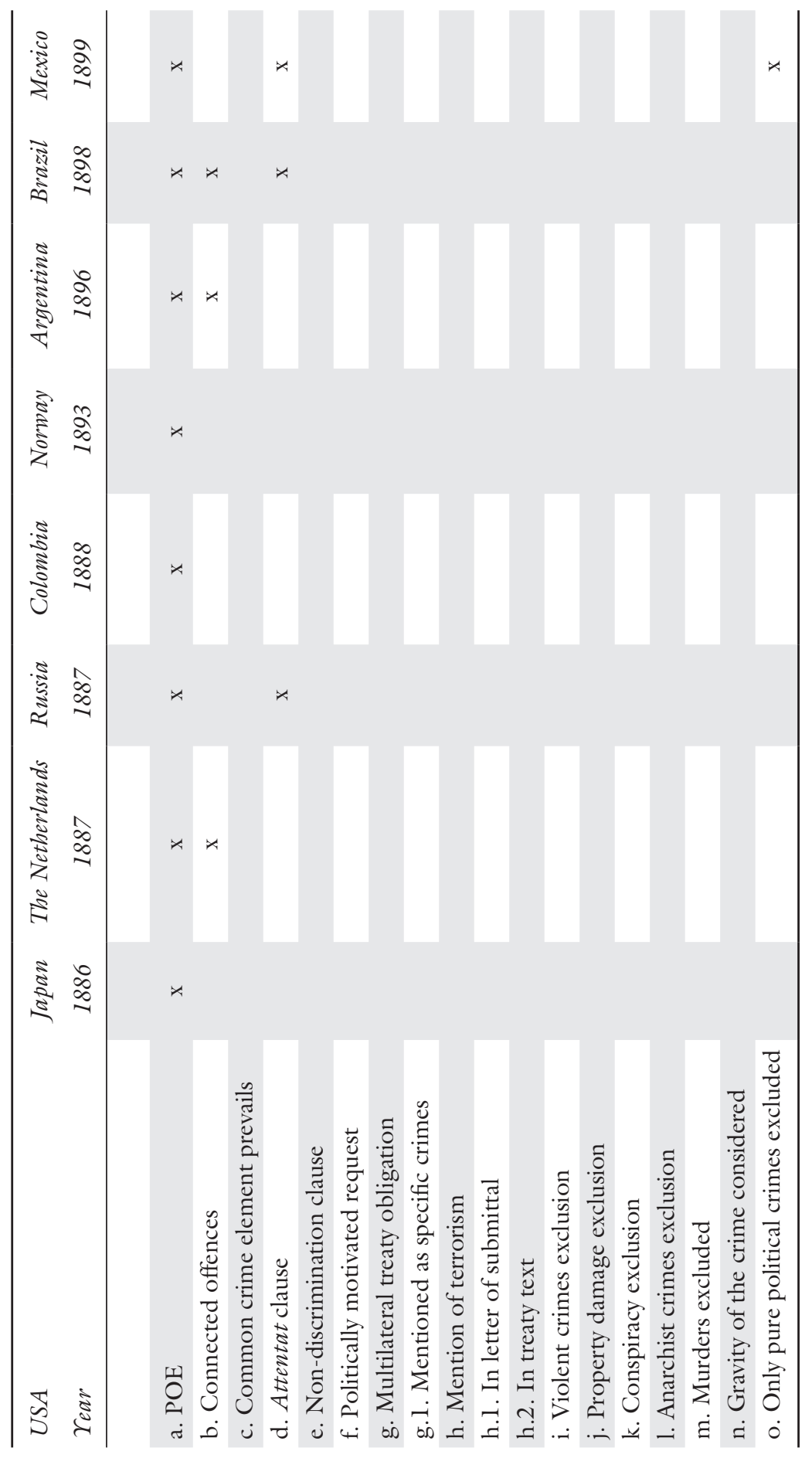




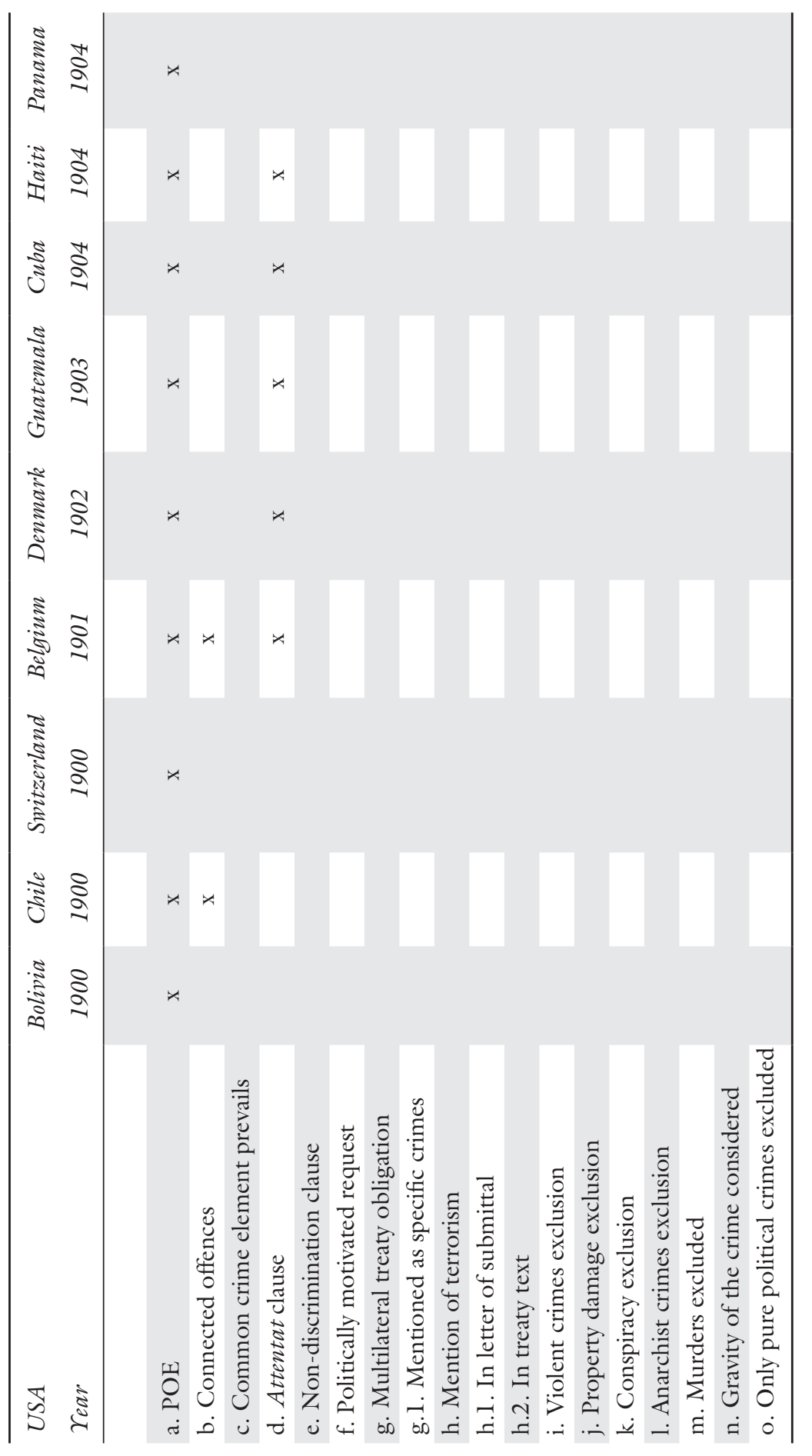




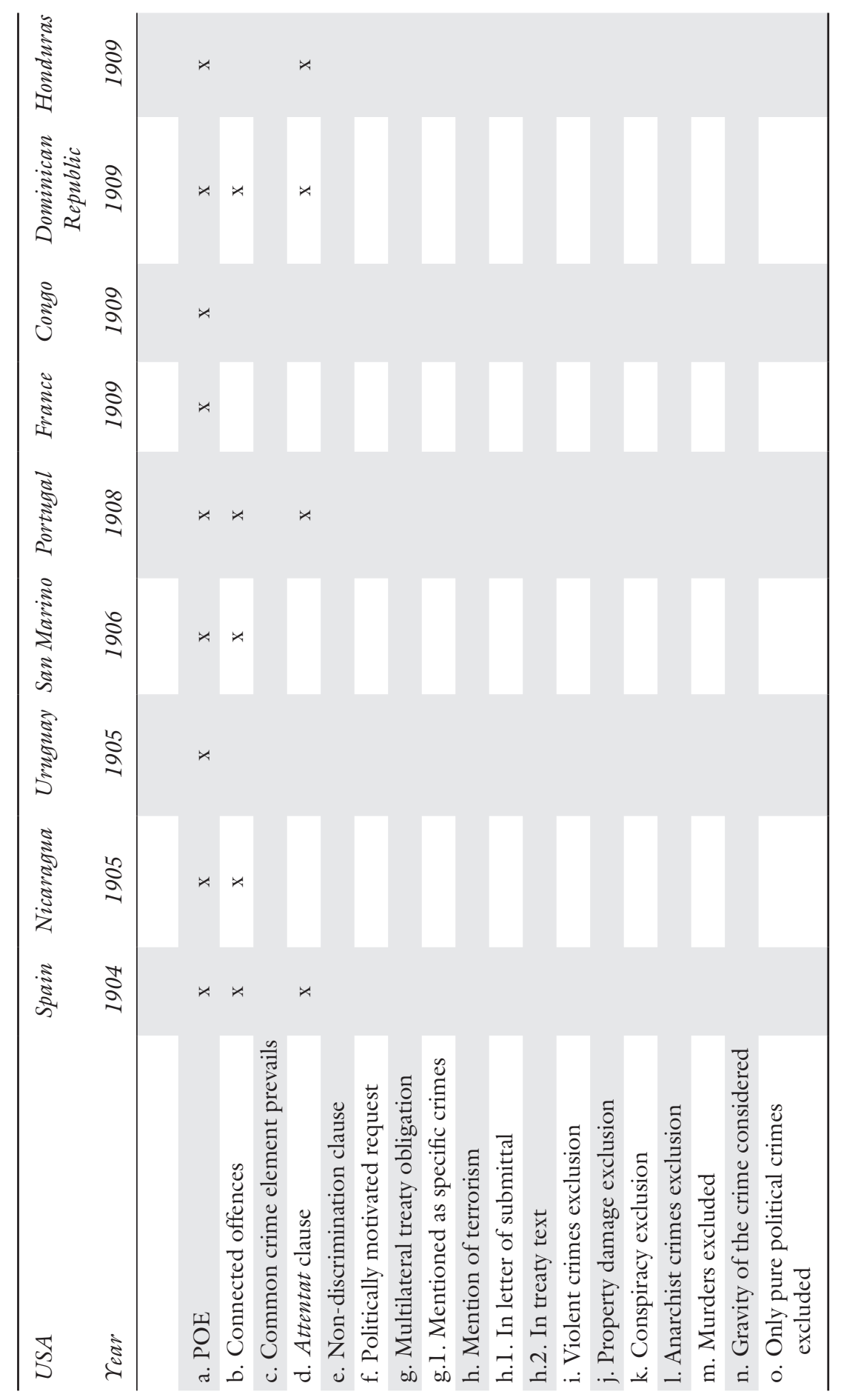




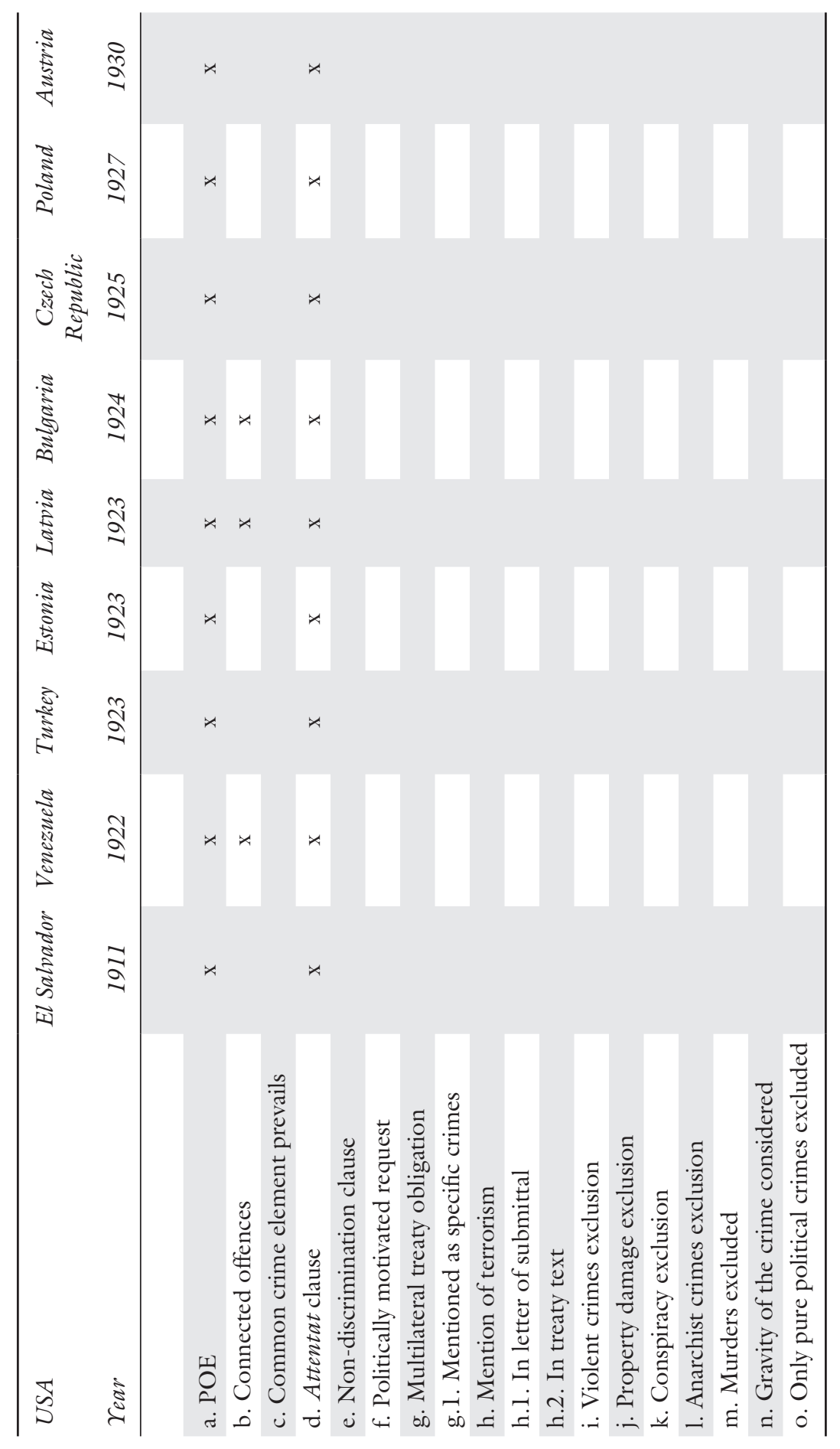




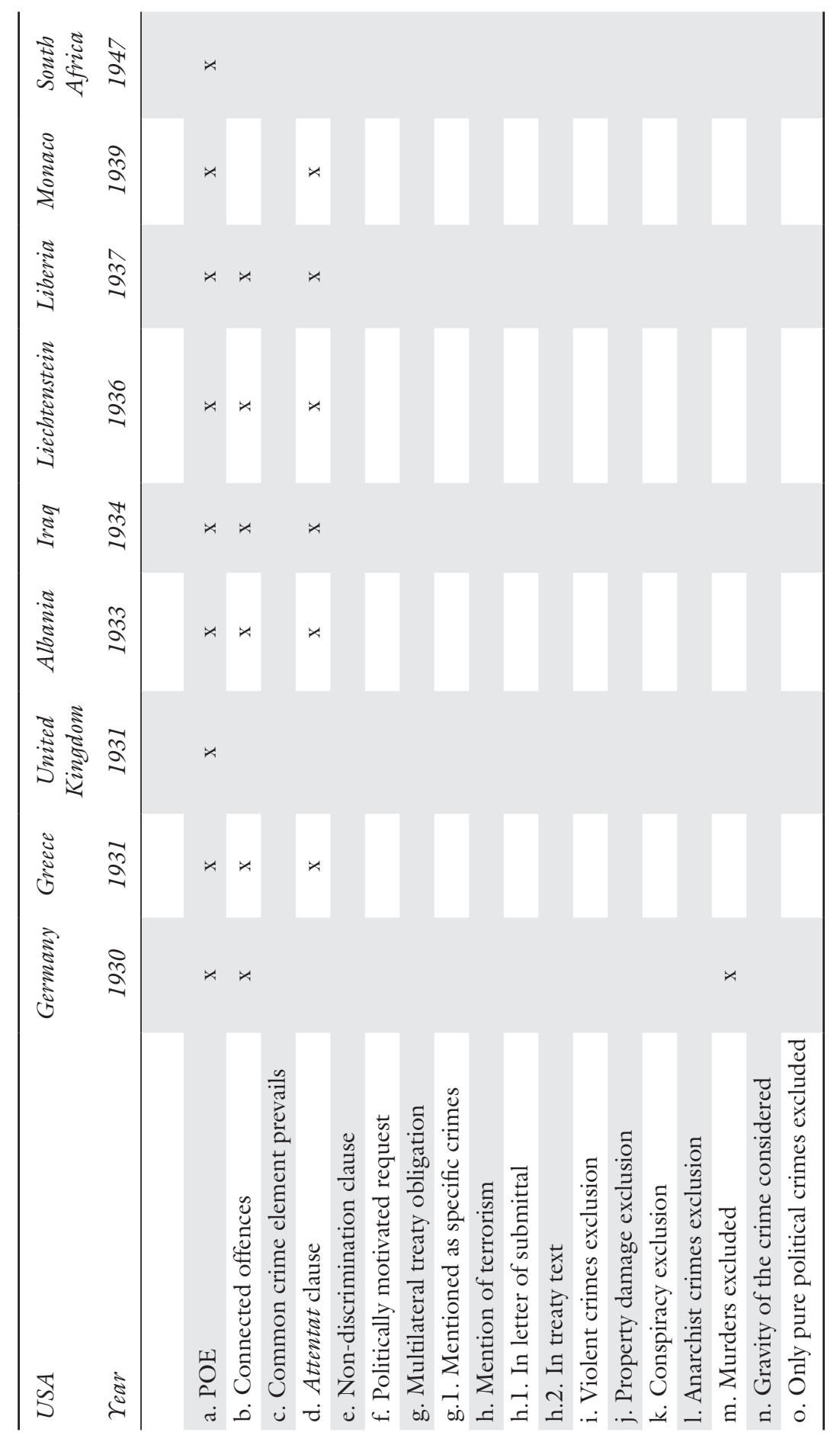




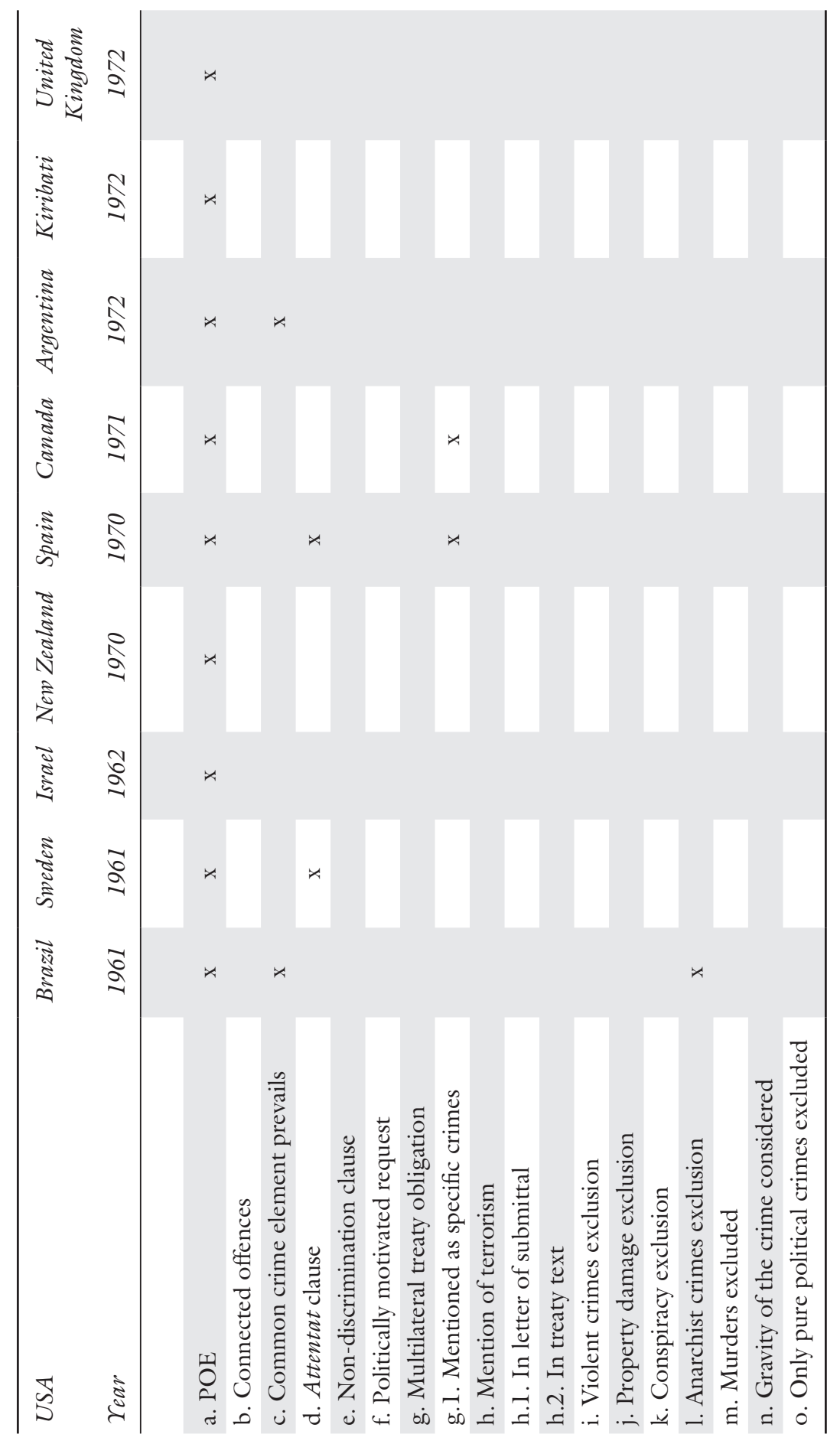




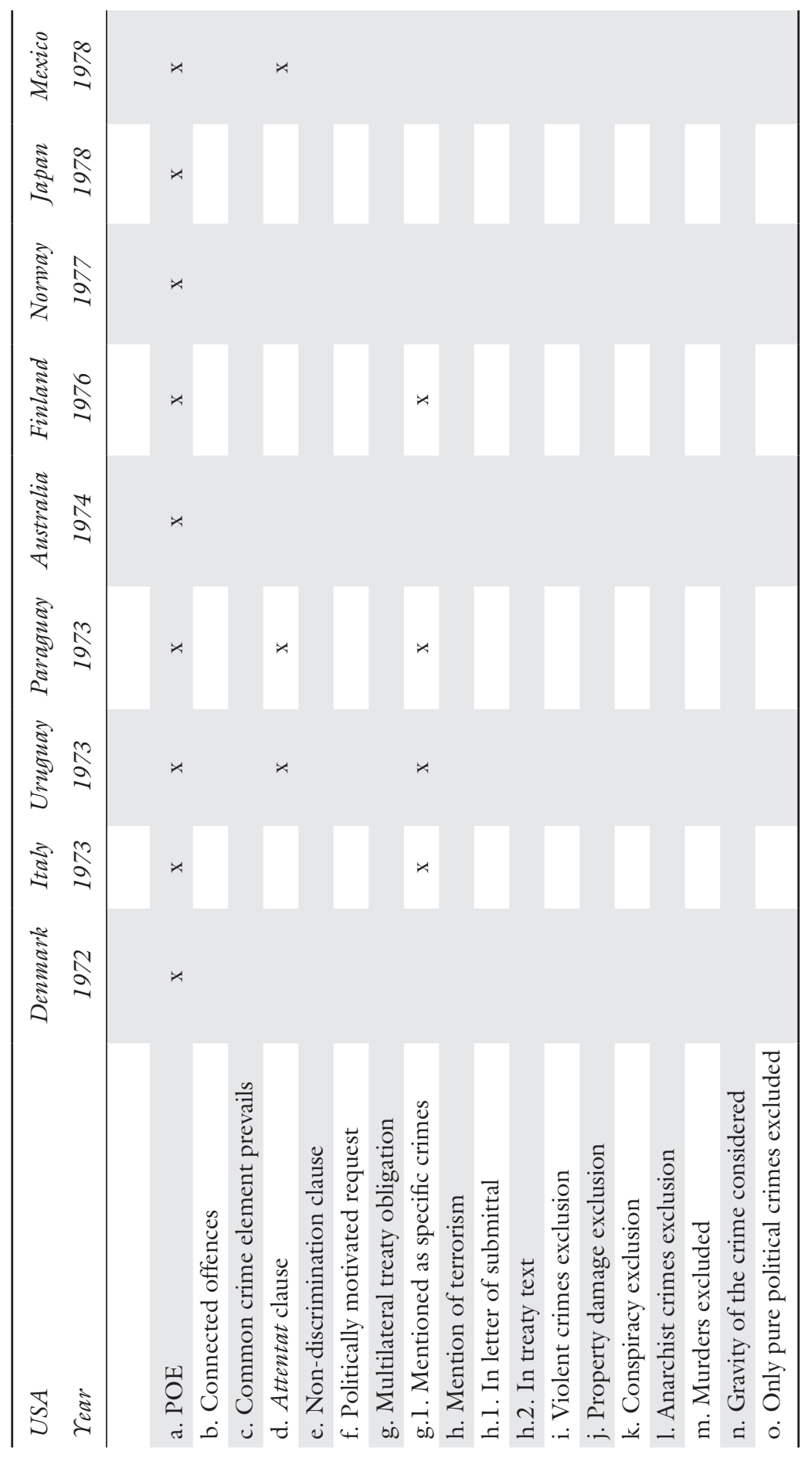




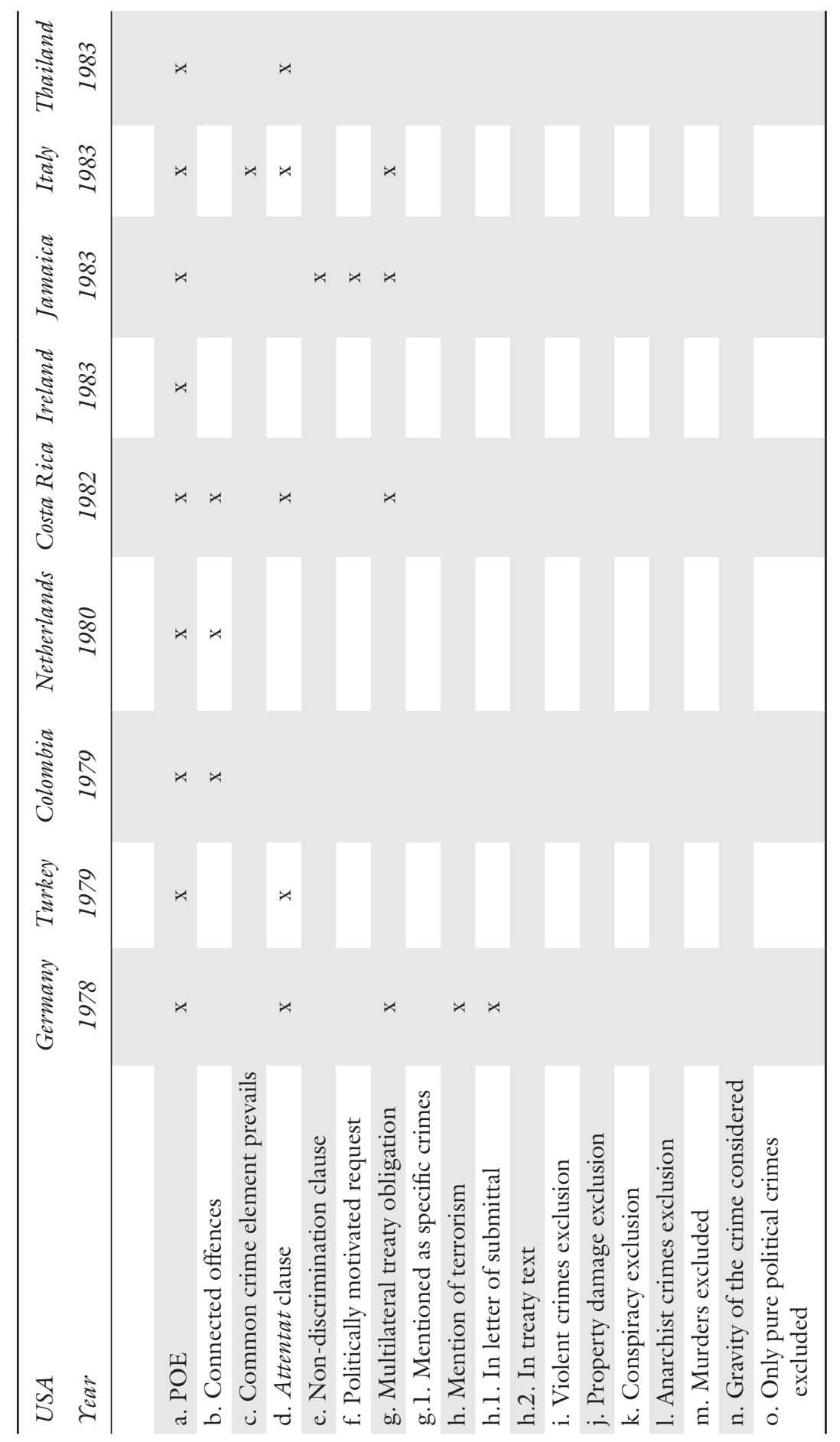




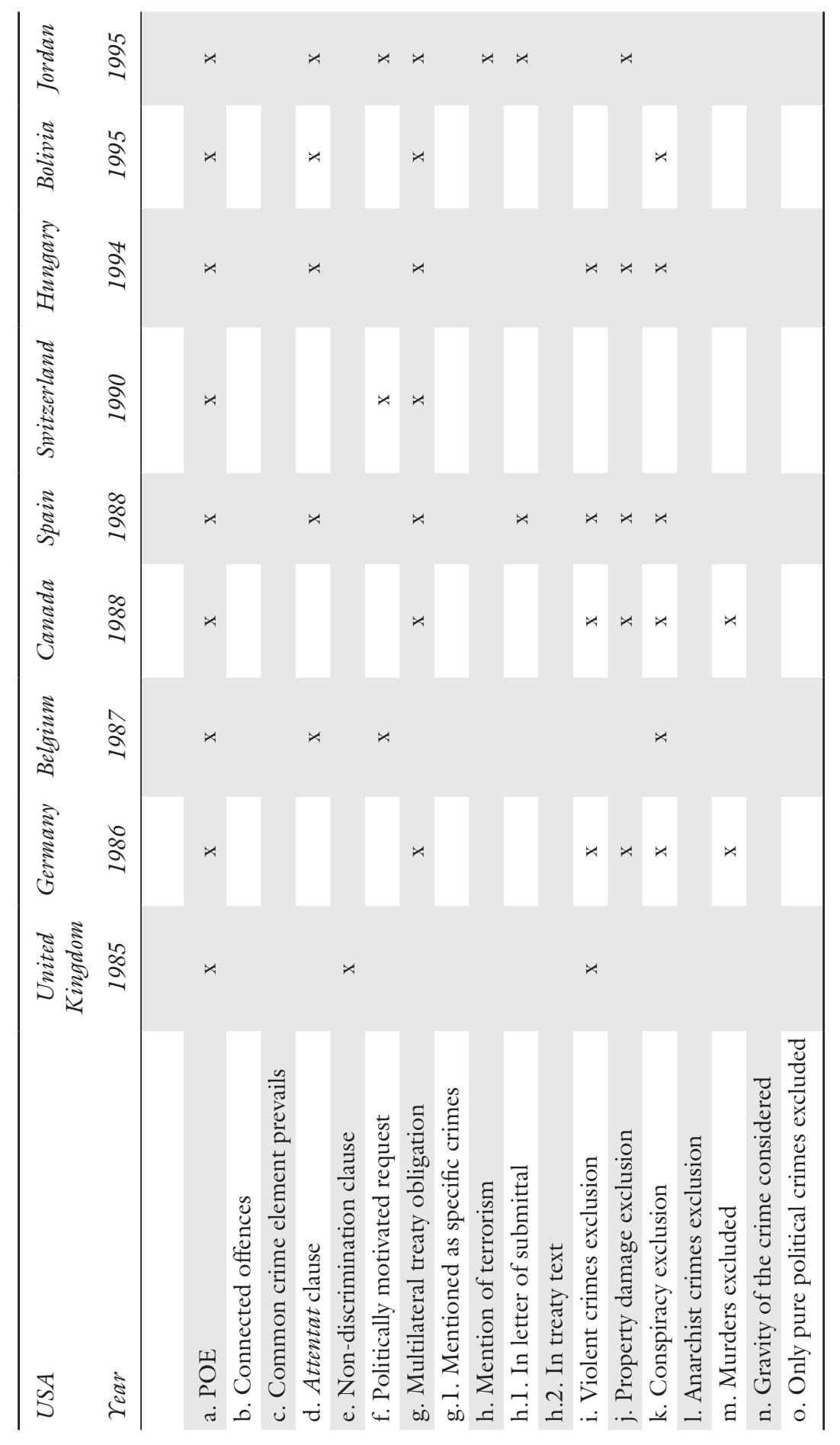




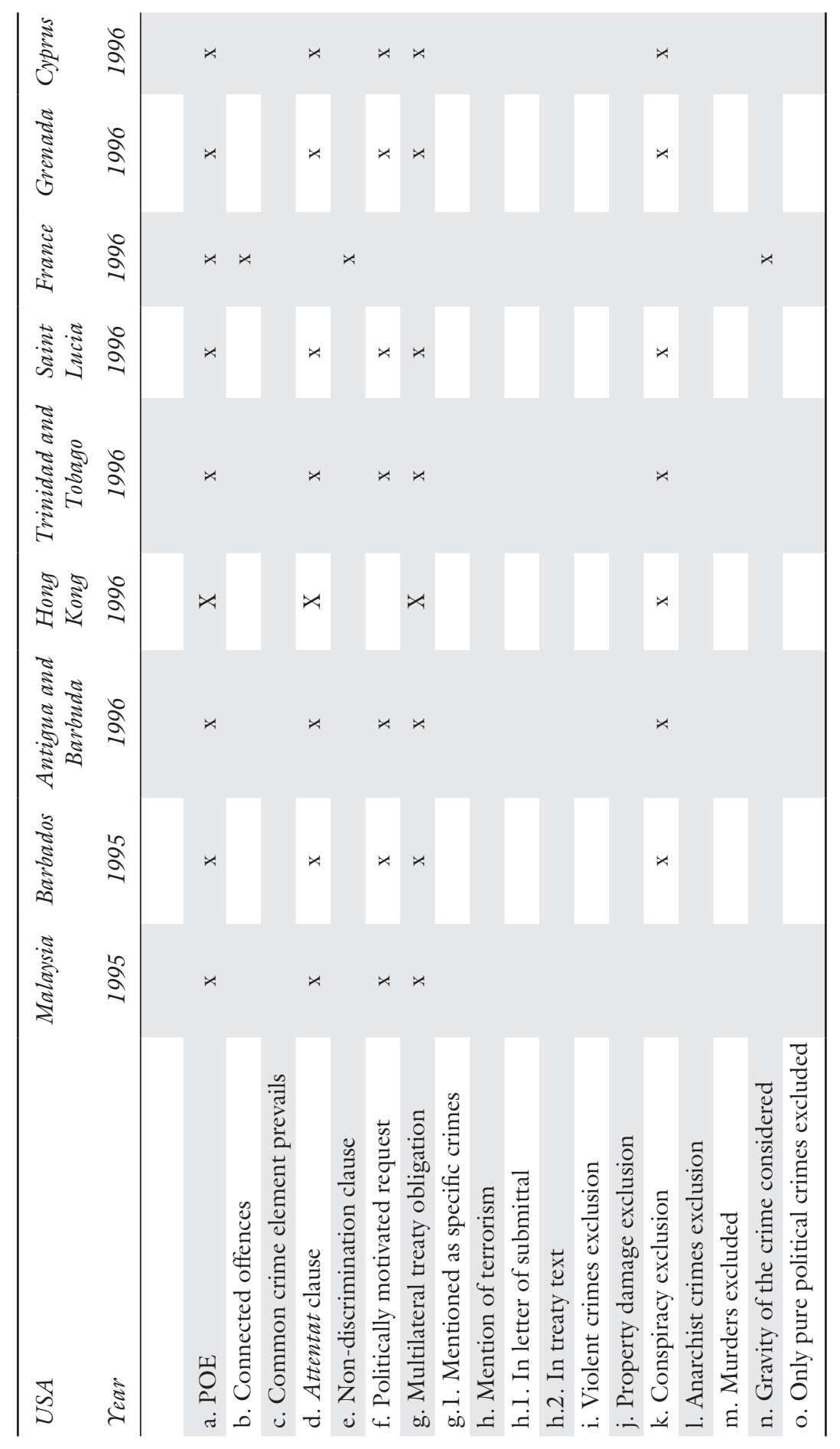




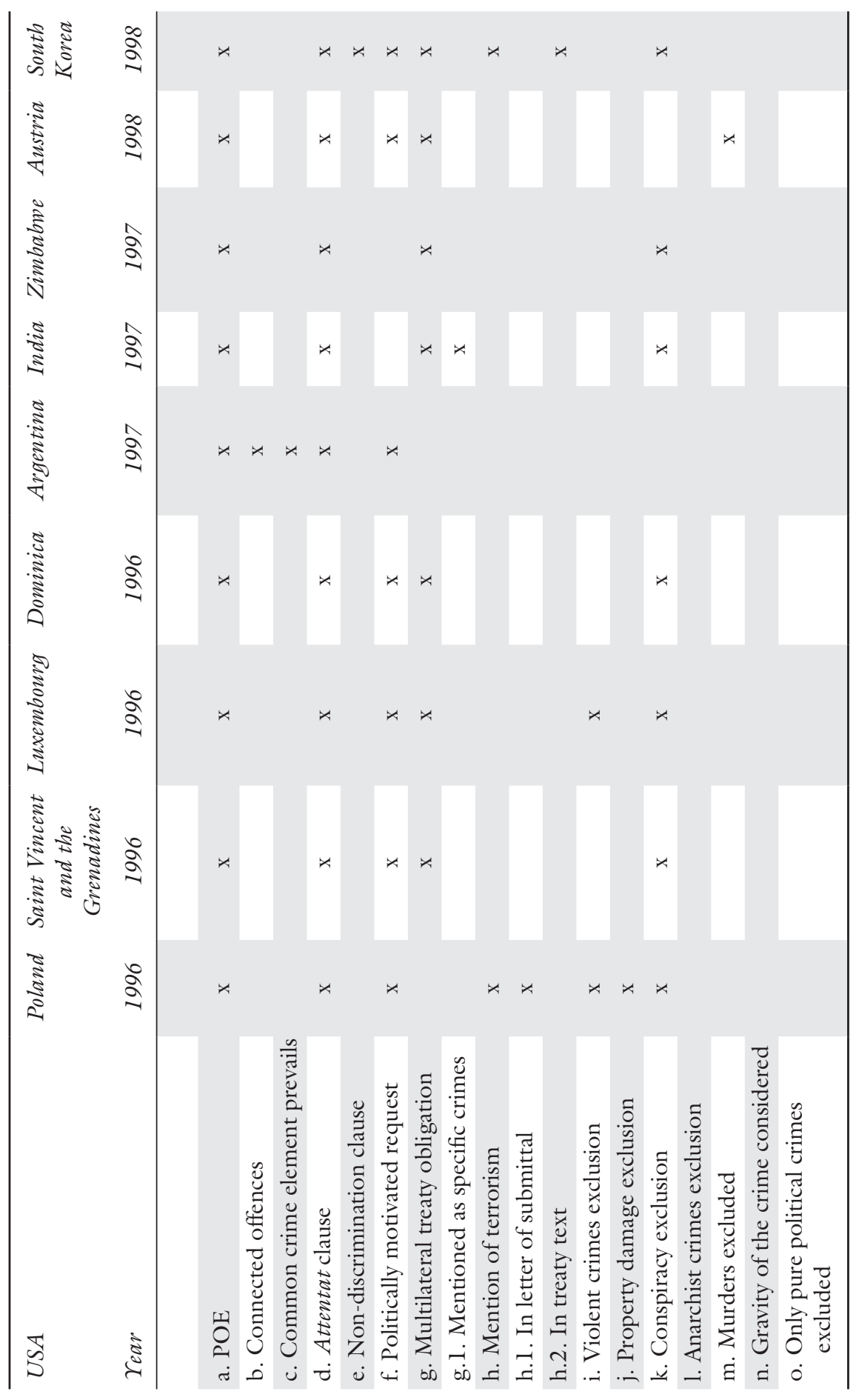




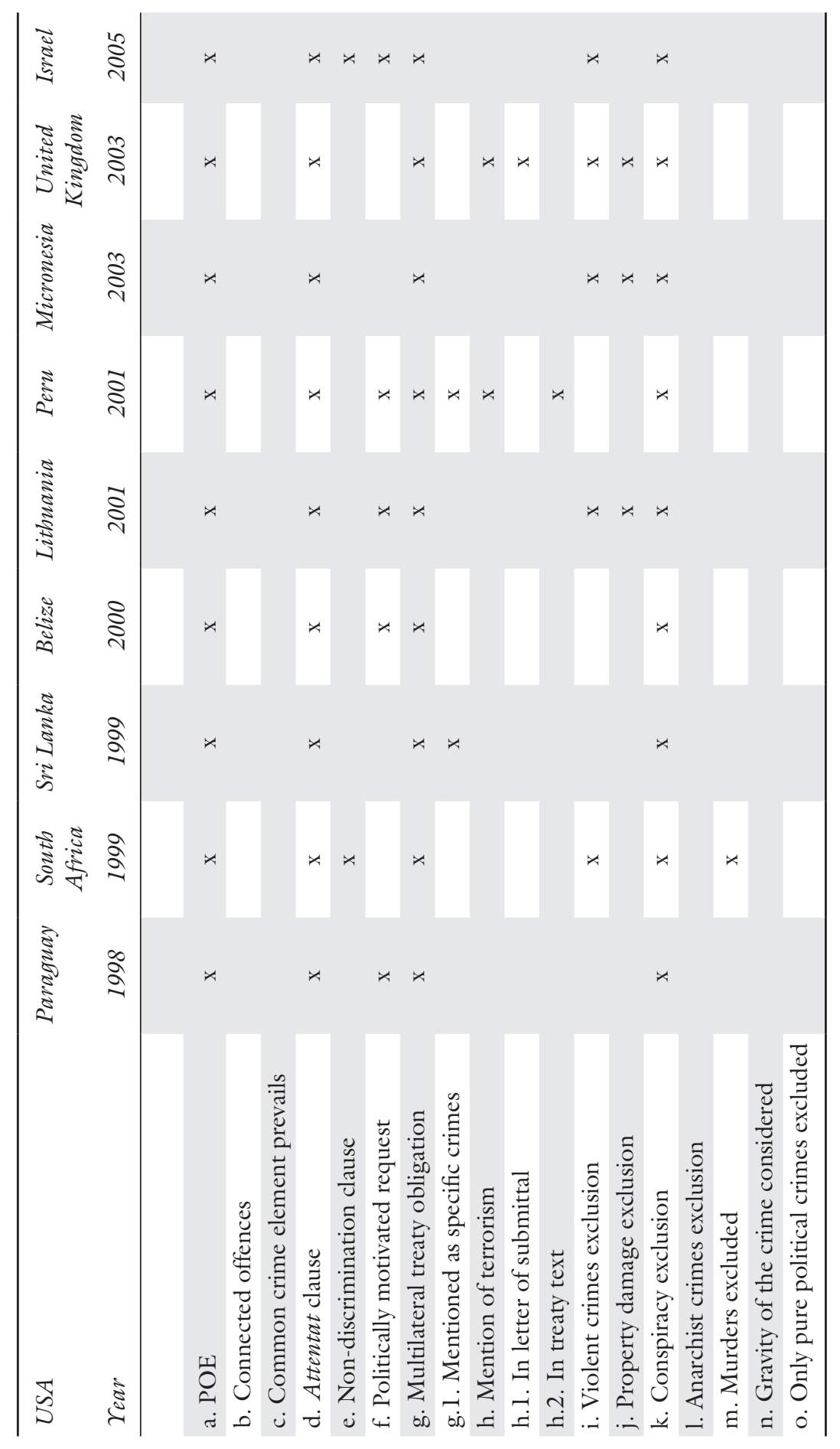




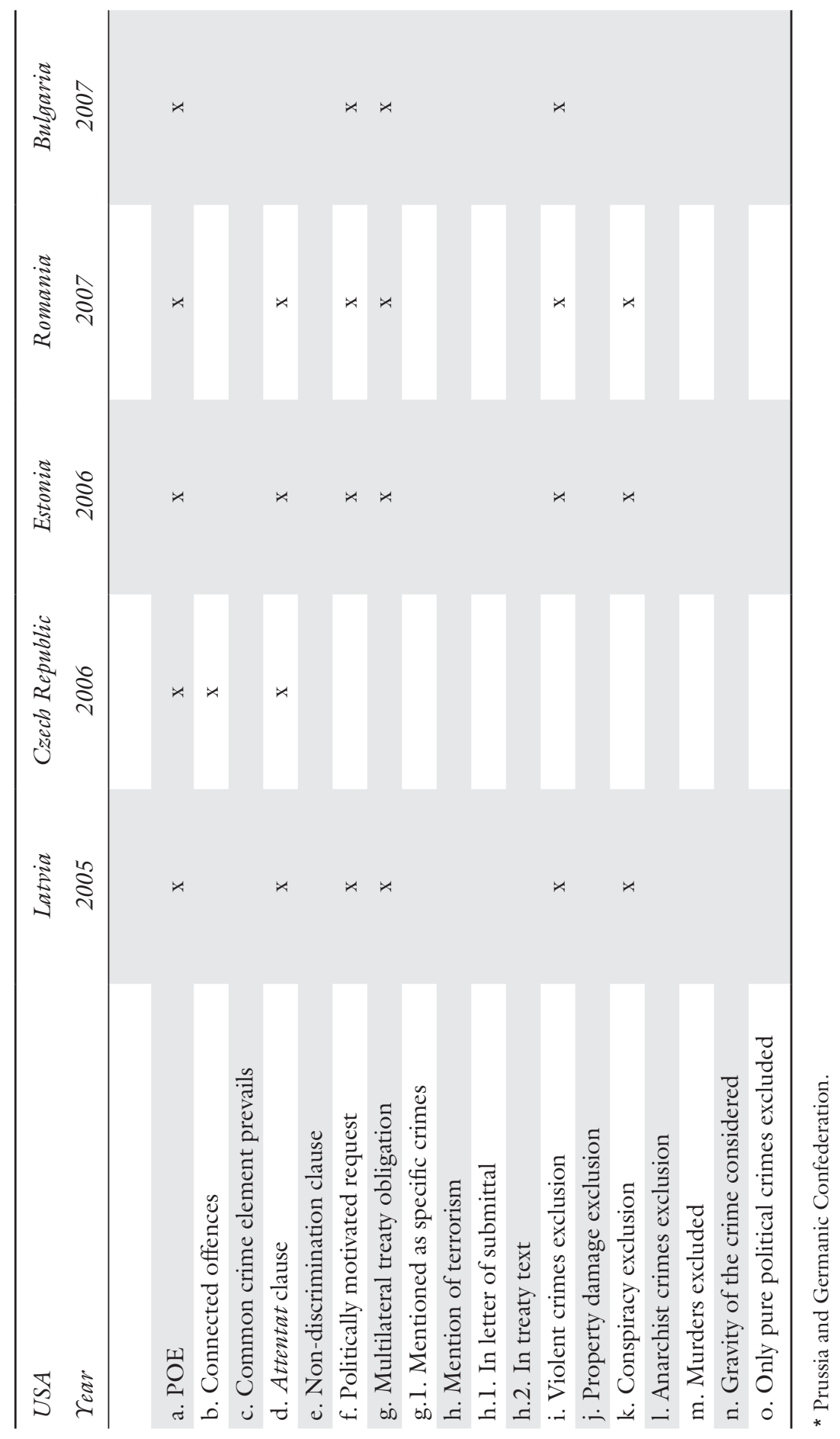




\section{Explanations of the terms used}

a. Contains the political offence exception (POE; different wordings are used in different treaties).

b. In the POE, in addition to political crimes or offences, also connected offences are protected from extradition.

c. Regardless of the political nature of the crimes, extradition is possible should the political element of the crime prevail.

d. Contains the Belgian or attentat clause excluding attacks against heads of state from the protection of the POE (variations of the clause are all included).

e. Contains the discrimination clause, which allows the state to refuse the extradition request should they evaluate that the fugitive could not receive a fair trial should they be extradited, due to for instance their race, political or religious opinions, or sexual orientation.

f. Allows for the denial of the extradition in case the request is considered to be politically motivated.

g. Limits the POE so that it does not cover international crimes that one of the parties to the treaty has a duty to extradite or prosecute, as a result of their obligations under the multilateral treaties they are party to.

g.1. Specific crimes contained in multilateral treaties are mentioned as extraditable, regardless of their political motivation/nature.

h. The treaty uses the term 'terrorism.'

i. The treaty categorically excludes violent crimes from the scope of the protection of the POE.

j. The treaty excludes damage to property from the scope of the protection of the POE.

k. The treaty excludes conspiracies to specific crimes from the scope of the protection of the POE.

1. The treaty excludes anarchist crimes from the scope of the protection of the POE.

m. All murders are excluded from the protection of the POE.

$\mathrm{n}$. The treaty party can consider the gravity of the crime in question when making the decision whether it is to be considered a political crime (comparative to the Swiss predominance test).

o. Only pure political crimes are considered political offences. 


\section{Index}

$9 / 11186$

22 July 1968, aircraft hijacking 114

1830s: attentat clause of 1856 85-91;

POE becomes widely accepted 77-85; reasons behind POE 91-5; revolution as evolution 71-77

1960-1980s: changes in US extradition treaties 110-113; Interpol 121-123; Iranian hostage crisis (1979) 131-132; new revolutionary wave 113-117; politics overrule legal concerns 117-121; terrorism alerts Europe 123-131; US draft convention (1972) 113-117

1980s: Eain v. Wilkes 133-137; legislative war against terrorists 133 ; POE loses justification 142-146; Supplementary Treaty (US and UK, 1985), 151-159; terrorism affects the US 137-142; US-UK controversies with regard to terrorism 146-151 1990s, changes in global views on terrorism: depoliticisation of terrorism 181-186; Interpol 168-172; UN and terrorism as unacceptable violence 172-181; US 161-168

2000s: applying POE 198-201; terrorism as evil ideology 186-188

Abbell, Michael 83, 85

Abu Daoud case 118 acceptance of POE (1830s) 77-85 accreditation for legal systems 204 Achille Lauro case, 140-141, 173 Acts of Violence Committed by

Organised Groups (1979) 132

Age of Revolution 71-72

Agreement Concerning the Application of the European Convention on the Suppression of Terrorism 129
Abmad v. Wigen (1989) 136

aircraft hijacking 111-112; 22 July 1968 114; Pan Am flight 103 141; TWA flight 847140

Alexander, Yonah 77

Allan, Richard 19

Al Qaeda 162

anarchism 229; 1937 convention 105-108; crimes against whole humankind 95-96; depoliticisation of (1898) 98-103; political goals 96-98; reasons for depoliticisation 104-105

'Anarchist' 96

"The Anarchist Beast" 97

Andreas, Peter 170

Anti-Anarchist Conference 102-103

anti-state terrorism 17

antiterrorism conventions, UN 111

Arab League 180

Arab States and Arab League

Extradition Agreement (1952) 89

arena-shifting 38

Argentina, US-Argentina treaty (1972) 90,110

Assange, Julian 11, 200

asylum 50-54, 205

attentat clause (1856) 85-91, 93-95, $145,163,225$; anarchism (turn of 20th century) 102; POE (political offence exception to extradition) 1

Aum Shinrikyo 162

Austria, US-Austria treaty (1998) 90

aut dedere ant judicare principle 36-37, 50, 111, 113, 115, 132, $173,202,206$

Banoff, Barbara Ann 144

Barabass, Ingrid 120

Barthou, Jean-Louis 105 
Bassiouni, M. Cherif 6, 14, 16, 22, 42-43, 52, 72, 76, 111, 114, 208-209

Basso, Kathleen A. 46

Bay, Christian 34

Belfast Agreement 197

Belgian clause 164

Belgian Extradition Act (1833) 83

Belgian-French treaty (1834) 83

Belgium: Extradition Act of 183374 ; US-Belgium treaty (1882) 83, 87-88

Belgium clause see attentat clause

Berlin disco bombings 141

bilateral treaties, extradition 40-41

Bingham, Lord $22 \ln 349$

Blakesley, Christopher L. 43, 140, 155-156, 209

'Black International' 96

Black Liberation Army 14

Black September 111; Munich Massacre (1972) 33

blunders 211

Boister, Neil 4, 41, 45

bombings: Lockerbie bombings 118 , 141; Oklahoma City bombing 162; USS Cole 162; World Trade Center bombing (1993) 162, 216-217

Bosch, Orlando 198

Brazil, extradition treaty with US 103,110

Brazil-Bolivia treaty (1938) 103

Brazil-Canada treaty (1995) 165

Brazil-Spain treaty (1988) 165

Bresler, Fenton 123

British Extradition Act (1870) 82-83

Buchwald, Magistrate 148

Buller, Jim 38

Bustamante code 84

"Cairo declaration on terrorism," Interpol 171

Canada: extradition treaties 158; US-Canada treaty (1971) 112-113

Canada-Italy treaty (2005) 90-91

Canada-South Africa treaty 194

Canada-Sweden extradition treaty (2000) 194

Carbonneau, Thomas 118, 119, 121

Carter, President Jimmy 142-143

cases: Abu Daoud 118; Achille Lauro 140-141, 173; Abmad v. Wigen (1989) 136; Cheng 59, 183; Croissant 119-120; Eain 111; Eain v. Wilkes 133-137; Ex parte Kolczynski 67-68;
Gonzales 64; Holder 118; In re

Castioni 58; In re Doherty 149; In re Ezeta 1894 59-62, 144; In re Giovanni Gatti 65-66; In re Kavic 67; In re Meunier 99-100; In re Nappi 67; In re Ockert 67; Jacquin 86; Jimenez v. Aristeguieta 64; Kolczynski 58-59, 183; Lynchehaun 61; MacCann 121; Mackin 147-148; McMullen 147-148; Meunier 183; Meza 199; Mylonas 64; Ng v. Canada 45; Ornelas 61-62; Ornelas v. Ruiz 183; Piperno and Pace 120; Quinn 135, 199; Quinn v. Robinson 150151; Ramos v. Diaz 63-64; Singh (2001) 167-168; Soering 44-45; V.P. Wassilieff 67; Winter 120

Castioni, Angelo 58

Castro, Fidel 198

Central Intelligence Agency (CIA) 215-216

changes in global views on terrorism, US 161-168

Cheng 59, 183

CIA (Central Intelligence Agency) 215-216

civilians, defining 207

Clark, J. Reuben 51, 86

"classic political trial" 11

classifying: political crime 15-16; terrorism 30-31

Clinton, President Bill 164-165

Clinton administration (US), counterterrorism 163

Coady, C. A. J. 22, 28, 196, 209

coercive diplomacy 33

Cohen, Aviv 177

collective violence 32

Colombia, US-Colombia treaty (1888) 83

Colombia-Panama treaty (1927) 103

Committee of Ministers of the Council of Europe 125, 188

common crimes $14,22,212$

Commonwealth Fugitive Offenders Act (1881) 81

Commonwealth Scheme Relating to the Rendition of Fugitive Offenders (1966) 81-82

comparing definitions of terrorism 25-26

compound political offences 15 connected offences 82-83 
Conte, Alex 183

contemporary Islamic terrorism 162

contentious politics 32

Convention Against Torture 46-47

Convention for the Prevention and Punishment of Terrorism (1937) 105-108

Convention for the Suppression of Unlawful Acts Against the Safety of Civil Aviation (1971) 112

Convention on the Prevention and Punishment of Crimes against Internationally Protected Persons 113 Coudert, Frederic 56, 85, 103

Council of Europe 6, 123, 124, 130; Committee of Ministers 125; Convention on the Prevention of Terrorism 219; Interpol 122

Counter-Terrorism Committee (CTC) 187

Counter-Terrorism Task Force 189

Counter Terrorist Group (CTG) 189 crimen majestatis 54

crimes against whole humankind, turn of 20th century 95-96

crimes of war 222

criminal approach, anti-terrorist actions 32

Criminal Jurisdiction Act (1975, UK) 215

criminal law 214

criminals, motives of 211-214

Croissant 119-120

Croissant, Klaus 119-120

CTC (Counter-Terrorism Committee) 187

CTG (Counter Terrorist Group) 189

Currie, Robert 44

custodia honesta 74

Damphousse, Kelly R. 214

decision-making power, executive branch 231

Declaration on Measures against International Terrorism (1994) 17-18

Declaration on Measures to Eliminate International Terrorism (1994) 174-175

Declaration on Territorial Asylum 53

Deflem, Mathieu 7, 39, 102, 171-172

de Graaf, Janny 30

de Kerchove, Gilles 184

delegitimisation of terrorism 228-230 demise of POE (political offence exception to extradition) 225-228

democracy, threats to 221-223

democratic state 73

depoliticisation 36-40; of anarchism (1898) 98-105; of terrorism 181-186, 228-230

deportation 45-46

"derivative political trial" 11

DeSchutter, Bart 181

D'Estaing, Valéry Giscard 119, 129

Diplock courts 156-157

diplomacy of violence 33

discrimination clause 47-48, 127, 205; Supplementary Treaty (US and UK, 1985) 153-154; US-France treaty (1996) 167

dismantling of POE: EAW (European Arrest Warrant) of 2004 188-194; POE in modern days 194-197; terrorism as evil ideology 186-188

Ditrych, Ondřej 107, 115, 181

Doherty 149

domestic terrorism 22

Draft Code of Crimes against the Peace and Security of Mankind (1991) 17n58

Draft Comprehensive Convention on International Terrorism 18

Draft Convention on Extradition, (1935) 81

dual criminality, anarchism 101

Dublin Convention 129

Eain 111

Eain v. Wilkes 133-137

EAW (European Arrest Warrant) 50

EAW (European Arrest Warrant) of 2004 188-194

ECHR (European Court of Human Rights) 44, 193

ECST (European Convention on the Suppression of Terrorism) 56 , 126-129, 158, 191, 228

Ecuador, US-Ecuador extradition treaty (1872) 200

EEC (European Economic Community) 123,129

embassy bombings in Kenya and Tanzania (1998) 162

emergence of POE (political offence exception), 1830s: acceptance of POE 77-85; attentat clause 85-91; reasons behind POE 91-95; revolution 71-77 
Emmerson, Ben 184

Empress Elisabeth of Austria 100

'encouragement of terrorism' 218

England, anarchists (turn of 20th century) 98-99

Entebbe hostages 125

Epps, Valerie 59, 64, 137, 202-203, 205,210

equal protection clause 47

Espina, Maria Natividad "Jaione" Jauregui 193

ETA activists 118-119

EU (European Union): EAW (European Arrest Warrant) of 2004 188-194; extradition agreement with US (2003) 197; Extradition Convention (1996) 19; Framework Decision on Combating Terrorism 24, 218

Europe, terrorism alerts Europe (1970s) 123-131

European Arrest Warrant (EAW) 2, 50

European Convention of Extradition (1957), discrimination clause 48

European Convention of Human Rights (ECHR) 193

European Convention on Extradition (1957) 82, 89, 95, 123

European Convention on Mutual Assistance in Criminal Matters (1959) 123-124

European Convention on the Suppression of Terrorism (ECST) 56, 81, 126-129, 190, 228

European Council 125; Action Plan 188

European Court of Human Rights (ECHR) 44

European Economic Community (EEC) 123,129

European Judicial Area 129

European Union Extradition Convention (1996) 19

Europol (European Police Office) 123,125

evaluating: incidence test 62-65; Supplementary Treaty (US and UK, 1985) 154-159

'evil ideology,' terrorism as 186-188

exceptions to the exception, attentat clause (1856) 85-91

executive branch, decision-making power 231

Ex parte Kolczynski 67-68

extradition 36-37; history of extradition of political criminals 54-56; human rights protections 44-50; POE versus political refugee $50-54$; political offenders see political offenders; reciprocal legal assistance 40-43

Extradition Act of 1833 (Belgium) 74

extradition treaties 4 ; 1960-1970s (US)

110-113; history of 54-56; human rights protections 44; US 78-79, 194-196, 204, 263-277; see also treaties

extraordinary rendition 46

Ezeta, A. 60

'fair trial' 204-205

FBI (Federal Bureau of Investigation) 216

Federal Bureau of Investigation) 216

'Feindstrafrecht' 221

Ferdinand, Archduke Franz 105

Ferrari, Robert 98, 211

financing terrorism, Interpol 170

Finland, repoliticisation of terrorism 219-220

First South American Congress on Private International Law (1889) 80

fixing POE (political offence exception to extradition) 201-211

Flinders, Matthew 38

Fooner, Michael 170

Fox News 200

Framework Decision on Combating Terrorism (EU, 2002) 24, 189-190, 218

France: Abu Daoud 118; asylum for two African Americans 112; ETA activists 118-119; injured rights theory 65-66; punishment for preparation and incitement of terrorism 218 ; US-France treaty $(1996) 79,165-167$

freedom fighters 19, 28, 157

freedom from persecution clause 47

French German treaty (1951) 90

French Revolution, political crimes 54

FRG (Federal Republic of Germany) 138-139

Gaddafi, Muammar 141

Galli, Francesca 220

Galotti case 74

Ganor, Boaz 183

García-Mora, Manuel R. 14, 82, 92, 94, 226

General Assembly (UN), condemnation of terrorism 172-181 
General Assembly Resolution 49/60 176

Geneva Conventions 34-35

German Extradition Act (1929) 10, 90

Germany: FRG (Federal Republic of Germany) 138; provisions of terrorism 219; US-Germany extradition treaty (1930) 89-90

Gilbert, Geoffrey, 4, 5, 52, 55-56, 69, $71,100,127,128,173,203,206$, $207,209,226$

Giovanni Gatti case 15

Global Terrorism database 23

'glorification' of terrorists 218-219

GMT (Multidisciplinary Group on International Actions against Terrorism) 188

Gold, Martin E. 208

Goluchowsky, Count 100

Gonzales 64

Good Friday Agreement (1998) 197

Green, L. C., 58, 122

Groarke, John Patrick 156, 207

Gurr, Ted Robert 33

Gustavsson, Gina 72

Hacker, Frederick 30

Hague Convention (1970) 111-112

Haig, Alexander 143

Hannay, William M. 43, 58

Harding, President Warren 213

hate crimes 214

Held, David 37, 169

Herbst, Philip 20

historico-legal approach 2-7

history of extradition of political criminals $54-56$

Hobsbawm, Eric John 71

Hoffman, Bruce 23

Hofmann, Sieglinde 120

Holder 118

Honduras International Extradition Treaty (1909) 87-88

'Hostages and Blackmail' 122

Hostages Convention 132

hostis 21

human rights law 71

human rights protections: extradition 44-50; for terrorists 214-221

ICC (International Criminal Court) 35-36, 210

ICCPR (International Covenant for Civil and Political Rights) 45
ICT (International Institute for

Counter-Terrorism) 24

ideologically motivated acts 20-29

IHL (international humanitarian

law) 17,35

IHRL (international human rights law) 17

IIL (Institute of International Law) 80

inchoate offences 218-220

incidence test 117; evaluating 62-65; US 59-62; US-France treaty (1996) 167

incitement of terrorism 219

India, US-India extradition treaty (1997) 167-168

Ingraham, Barton L. 9, 76, 232

inimicus 21

injured rights theory (France) 65-66

In re Castioni 58

In re Doherty 149

In re Ezeta 1894 59-62, 144

In re Giovanni Gatti 65-66

In re Kavic 67

In re Meunier 99-100

In re Nappi 67

In re Ockert 67

Institute of International Law (IIL) 47, 80; Geneva meeting (1892) 89

Inter-American Convention on Extradition (1933) 88

International Conference of Rome for the Social Defence Against Anarchists 100-101

International Convention Against the Taking of Hostages 132

international courts 210

International Covenant for Civil and Political Rights (ICCPR) 45

international crime 34-36

International Criminal Court (ICC) $35-36,210$

International Criminal Police Organisation see Interpol

International Humanitarian Law (IHL) 17,35

international human rights law (IHRL) 17

International Institute for CounterTerrorism (ICT) 24

International Law Commission, Draft Code of Crimes against the Peace and Security of Mankind (1991) 17n58

International Penal and Prison Commission (1931) 89 
international terrorism $17 \mathrm{n} 58,22,27$, 116,173

Interpol 4, 32, 121-123, 122n80, 228; new understanding of terrorism $168-172$

Interpol General Assembly, (September 2001) 187

IRA (Irish Republican Army) 121, $146-151,159,170$

Iran 161

Iranian hostage crisis (1979) 131-132

Ireland 146-151; IRA (Irish Republican Army) 121, 146-151, 159, 170; Northern Ireland 209; PIRA (Provisional Irish Republican Army) $117,146-152$

Irish Criminal Law (Jurisdiction) Act (1976) 215

Irish Republican Army (IRA) 121, 146-151, 159, 170

Israel: Abmad v. Wigen (1989) 136; aircraft hijacking, 22 July 1968 114; Eain 111; US-Israel extradition treaty 136

Italian Court of Appeal of Turin 94

Italy: anarchists (turn of 20th century) 100; US-Italy treaty (1973) 112; US-Italy treaty (1983) 145

Jacobean Constitution 73

Jacquin, Celestin 86

Jacquin case 86

Jakobs, Gunther 221

Jamaica, US-Jamaica treaty (1983) 145

Jenkins, Philip 3, 18-19, 22, 107, 138,217

Jensen, Richard Bach 87, 95, 100, 101

Jimenez v. Aristeguieta 64

Jordan, US-Jordan treaty (1995) 164-165

jus cogens 44

Justice and Home Affairs Council 188

justified violence 208-209

Kaufman, Whitley 214

King Alexander of Yugoslavia 105

King Umberto I of Italy 102

Kirchheimer, Otto 9, 10-11, 21, 68, 74, $92,105,106,200$

Klabbers, Jan 1, 127, 184-185

Kolczynski 58-59, 183

Koskenniemi, Martti 184

Kropotkin, Peter 97
Kudnani, Arun 187

Kulman, Bradley G. 91, 153, 154, 202

Lampo, Steve 136

laws 9-10

League of Nations, Convention for the Prevention and Punishment of Terrorism (1937) 105-108, 210

League of Nations Convention, International Status of Refugees (1933) 49

legal concerns (1970s-1980s) 117-121

legal fiction 185

legality 221

legislative war against terrorists (1980s) 133

Libya, Lockerbie bombings 118 , 141-142

Lieberman, David M. 56, 93, 150

limited political terrorism 30

limiting the POE 203, 206-207

Lithuania, US-Lithuania treaty (2001) 195

Lockerbie bombings 118, 141

Lodge, Juliet 129

London train attacks (2005) 188

Lubet, Steven. 50-51, 63

Lucheni, Luigi 95

Lynchehaun 61

Lynchehaun, James 61

Maastricht treaty 191

MacCann 121

McElrath, Karen 46, 150, 159

Mackin 147-148

McMullen 147-148

McMullen, Peter Gabriel John 154

McVeigh, Timothy 162

Madrid train attacks (2004) 188

mala in se 16

mala probibita 16

Manning, Chelsea 201

Marcos, Ferdinand 157

Measures to Eliminate International Terrorism (1991) 174

Measures to Eliminate International Terrorism (1997) 175-176

Melia, Manuel Cancio 222

Memorial Institute for the Prevention of Terrorism (MIPT) 28-29

Mercosur, Bolivia and Chile treaty (1998) 165

Mercosur extradition treaty (1998) 179 
Meunier 183

Mexico: US-Mexico treaty (1899) 79;

Mexico-US treaty (1978) 113

Meysman, Michaël 193

Meza 199

Meza, Carlos Yacaman 199

MIPT (Memorial Institute for the

Prevention of Terrorism) 28-29

Mitterand, François 119

Mitterand doctrine 119

mixed political crimes 15

Model Draft of an Extradition Treaty 89

Model Treaty on Extradition (1990) 174

Model Treaty on Mutual Assistance in Criminal Matters (1990) 174

Montevideo Convention on Extradition (1933) 82

Montreal Convention (1971) 111

Moore, John Norton 203

Moore, Kelly Anne 184

Moro, Aldo 120, 129

Morocco, US-Morocco treaty (2013) 194

motives of criminals 211-214

Mujahedin (Afghanistan) 162

Multidisciplinary Group on

International Action against

Terrorism (GMT) 188

multilateral treaties, extradition 41-42

multilateral treaty clause 163

Munich Massacre (1972) 33, 114, 118,122

Murphy, John F. 31, 151, 186

Mylonas 64

Nadelmann, Ethan A. 170

Naert, Frederik 192-193

National Central Bureaus 122

national liberation movements 116

nerve gas attack (Tokyo subway system, $1995) 162$

New Guidelines for Co-operation in Combating International

Terrorism 170

new revolutionary wave (1960-1980s)

$$
\text { 113-117 }
$$

$\mathrm{Ng}$, Chitat 45

Ng v. Canada 45

Nichols, Terry 162

Nixon, President Richard 114

Noble, Ronald 186

non-combatants 23 non-extradition of nationals 49

non-political terrorism 30

non-refoulement principle 47-49, 52-53

Noone, Michael F. 77

Northern Ireland 146-151, 209

OAU (Organisation of the African Unity) 178-179

Oehmichen, Anna 214, 220

Office of International Affairs (OIA) 143

official terrorism 30

OIA (Office of International Affairs) 143

Oklahoma City bombing 162

Oppenheim, Lassa 80-81

oppositional 10

ordinary crimes 27

Organisation of the African Unity (OAU) 178-179

Organisation of the Islamic Conference on Combating International

Terrorism (1999) 179

organised crime 31

Ornelas 61-62

Ornelas v. Ruiz 183

overinclusiveness, incidence test 63

Palestinian Liberation Organisation (PLO) 118

Palestinians: aircraft hijacking 111, 114; Black September 33

Palonen, Kari 37

Pan American Convention on Territorial Asylum (1954) 82

Pan American Treaty (1902) 103

Pan Am flight 103141

parallel punishments 74

Parliamentary Assembly of the Council of Europe 188

Petersen, Antje 92, 202, 207

Petzsche, Anneke 222

Piemonte, Christina 199

Piperno and Pace 120

PIRA (Provisional Irish Republican Army) 117, 146-152

piracy 111

PLO (Palestinian Liberation Organisation) 118

POE (political offence exception to extradition) $1-2$; applying in the 2000s 198-201; attentat 
clause 1; demise of 225-228; versus discrimination clause 47-8; dismantling of 186-197; fixing 201-211; history of extradition of political criminals 55-56; limiting 203, 206-207; loses justification (1980s) 142-146; versus political refugee 50-54; reasons behind POE (1830s) 91-95; US courts 43

Poland: Kolczynski 58-59; US-Poland treaty 167

political asylum $50-51$

political change 202

political crimes $7,27,92,189,212-$ 213; classifying 15-16; defining 9-15; mixed political crimes 15

political criminals 184; history of extradition of 54-56

political demands of terrorists 217

political goals, of anarchists, turn of 20th century 96-98

political incidence test, $57-65$

"political offence" 12-13; common definition 124

political offence exception to extradition see $\mathrm{POE}$

political offenders $15-16,51,56-57$; French injured rights theory 65-66; incidence test (US) 59-62; political incidence test (UK) 57-59; predominance test $66-69$; romantic liberalism 72-73

political refugee, versus POE (political defence exception) 50-54

political terrorism 30,162

political trials 10-12

political violence $30,32,202$

politicisation of POE 231-232

politics: contentious politics

32; overruling legal concerns (1970s-1980s) 117-121; terrorism 22-23

Posada, Luis 198-9

“positive approach" 207

predominance test 66-9, 121-122;

US-France treaty (1996) 166

Princip, Gavrilo 105

principle of legality 221

proportionality test 205-206

protection from unfair trials, reasons

behind POE (1830s) 91

Provisional Irish Republican Army (PIRA) 117, 146-152

'provocation of terrorism' 218-219
Pyle, Christopher H. 6, 42, 55, 63, 65, 74, 76, 78, 98-99, 113, 133, 135, $142,144,153-154,157-158,204$, 206, 208-209, 226

quasi-terrorism 30

Quinn 135, 199

Quinn, William 150

Quinn v. Robinson 150-151

radicalisation 187

Ramos v. Diaz 63-64

Reagan, President Ronald 137, 142143,157

Reagan administration (US) 133; POE loses justification 142-6; Supplementary Treaty (US and UK, 1985) 151-154

reciprocal legal assistance, extradition, $40-43$

Recommendation 703 on International Terrorism 124

Recommendation 852 on Terrorism in Europe 130

Recommendation 916 on the Conference on "Defence of Democracy Against Terrorism in Europe--Tasks and Problems" 130

Recommendation 1534 on Democracies Facing Terrorism 188

Recommendation 1550 on Combating Terrorism and Respect for Human Rights 189

Recommendation on International Terrorism 124

Red Scare 138n186

Refugee Convention 53, 68-69; Article 3347

refugees 51; non-refoulement principle $48-49$

refugee status 52

relative political offence 16

religious terrorism 161-162

repoliticisation of terrorism 40, 230; human rights for terrorists 214-221; motives of criminals 211-214; threats to democracy 221-223

Report of the Task Force on Disorders and Terrorism (1976) 30

Resolution (74) 3 on International Terrorism 125

Resolution 731 (UN) 141

Resolution 1258188

Resolution 1368187 
Resolution 1373187

revolution, as evolution (1830s) 71-77

revolutionary mass movements 116

right to refuse extradition $49-50$

right to resist 73

Riyadh Arab Convention 180

Rogers, William P. 137, 168

romanticism 74

romantic liberalism 3, 72

Rome Anti-Anarchist Conference 182

Roosevelt, Theodore. 95

Ross, Jeffrey I. 7, 14, 21

Rossi, Luigi 58

rule of non-inquiry 60

rules of law $22 \ln 349$

Russia, anarchists (turn of 20th century) 96

SAARC (South Asian Association for Regional Cooperation) 158

Said, Wadie E. 215

Sapiro, Miriam E. 91, 93

Saul, Ben 7, 18, 20, 36, 132, 184, 185, 208-209, 213, 217

Savia, Della 67

Schengen acquis 191

Schlaefer, Cindy 43, 139, 206

Schmid, Alex P. 7, 18, 21, 29, 30, 128

Schmitt, Carl 7, 20, 98, 182, 222-223

secular terrorism 162

September 11, 2001 186

Seventh Circuit Court of Appeals, US 134

Shkar, J. N. 3, 11, 227

Singh (2001) 167-168

Smith, Brent L. 214, 216

Snowden, Edward 201

Soering 44-55

Sofaer, Abraham 140, 150, 226

South Asian Association for Regional Cooperation (SAARC) 158

Soviet Union 163

Søvndal, Villy 184

Spain: ETA activists 119; 'glorification' of terrorists 219; US-Spain treaty (1970) 111

Spain-US treaty (1970) 83

Spear, Samuel T. 72

Special Tribunal for Lebanon (STL) (2012) 36

Sprizzo, Judge 149

Stanbrook, Clive 93, 208

Stanbrook, Ivor 93, 208

state terrorism 17, 30
Stethem, Robert 140

STL (Special Tribunal for Lebanon) (2012) 36

subversives 226

Supplementary Convention 210

Supplementary Treaty (US and UK, 1985) 151-159, 182

Suppression of Terrorism Convention 210

Swiss Federal Tribunal 94

Switzerland: predominance test 66-69; US-Swiss extradition treaty (1990) 201

Tamburini, Francesco 102

Task Force on Combatting Terrorism (1986), US 145

technological terrorism 180

terrorism: affects the US (1980s)

137-142; classifying 30-31; comparing definitions 25-26; defining 16-21; Europe 1970s 123-131; historico-legal approach 2-7; as international crime 34-36; Interpol 121-123; Iranian hostage crisis (1979) 131-132; legal concerns and politics 117-121; as unacceptable violence 172-181; as uncivil disobedience 29-34; US-UK controversies with regard to terrorism (1980s) 146-151

Terrorism (1983, Interpol resolution) 169

Terrorism Act 2000 (UK) 24, 218

Terrorism Act 2006 (UK) 218

Terrorism Financing Convention 178

Terrorist Bombings Convention, (UN) 176

Terrorist Financing Convention 18 'terroristic' violence (1960-1980s) 113-117

terrorists 11,28 ; human rights protections 214-221

'terrorist targets' 216

tests: evaluating incidence tests 62-65; French injured rights theory 65-66; incidence test (US) 59-62; political incidence test (UK) 57-59; predominance test 66-69; proportionality test 205-206

Thatcher, Margaret 148, 152

'Third World,' politics overrule legal concerns (1970s-1980s) 117-121

threats to democracy 221-223

Tilly, Charles 28nl17, 32, 232 
Tokoro, Kazuhiko 9, 76, 232

Tokyo Convention (1963) 111

torture, extradition 46-47

treaties: Belgian-French treaty

(1834) 83; Brazil-Bolivia treaty

(1938) 103; Brazil-Canada treaty

(1995) 165; Brazil-Spain treaty

(1988) 165; Canada-Italy treaty

(2005) 90-91; Canada-South

Africa treaty 194; Canada-Sweden

extradition treaty (2000) 194;

Colombia, US-Colombia treaty

(1888) 83; Colombia-Panama treaty

(1927) 103; Honduras International

Extradition Treaty (1909) 87-88;

Model Draft of an Extradition Treaty

89; Model Treaty on Extradition

(1990) 174; Supplementary Treaty

(US and UK, 1985) 151-159,

182; Treaty of Amiens (1802)

41-42; Treaty on Cooperation

180; UK-India extradition treaty

(1993) 129-130; US-Argentina treaty

(1972) 90, 110; US-Austria treaty

(1998) 90; US-Belgium extradition

treaty (1882) 83; US-Belgium treaty

(1882) 87-88; US-Brazil treaty

(1961) 103, 110; US-Canada treaty

(1971) 112-113; US-Colombia treaty

(1888) 83; US-Ecuador extradition

treaty (1872) 200; US-France treaty

(1996) 79, 165-167; US-FRG treaty

(1978) 138-139; US-Germany

extradition treaty (1930) 89-90;

US-India extradition treaty (1997)

167-168; US-Israel extradition

treaty 136; US-Italy treaty (1973)

112; US-Italy treaty (1983) 145;

US-Jamaica treaty (1983) 145;

US-Jordan treaty (1995) 164;

US-Lithuania treaty (2001) 195;

US-Mexico treaty (1899) 79;

US-Morocco treaty (2013) 194;

US-Poland treaty 167; US-Spain

extradition treaty (1970) 111;

US-Swiss extradition treaty (1990)

201; US-UK extradition treaty

(1972) 152; US-UK treaty (1889)

84; US-UK treaty (2003) 196;

US-United Arab Emirates (2006) 194

treaty-based crimes 35

Treaty of Amiens (1802) 41-42

Treaty on Cooperation 180
TREVI 123, 125

Tulkens, Françoise 207

turn of 20th century: 1937 convention 105-108; anarchists 95-98; depoliticisation of anarchism (1898) 98-103

TWA flight 847140

'two logics of exception' 115

Tyler, Judge 64, 78

UDHR (Universal Declaration of Human Rights) 53, 73

UK (United Kingdom): controversies with US over terrorism (1980s) 146-151; political incidence test 57-59; Terrorism Act 2000 218; Terrorism Act 2006 218; US-UK treaty (1889) 84; US-UK treaty (2003) 196

UK Criminal Jurisdiction Act (1975) 215

UK Extradition Act (1870) 94

UK-India extradition treaty (1993) 129-130

UK Terrorism Act 2000 24; Supplementary Treaty (US and UK, 1985 ) 151-154

Ulloa, Luis Rolando Valenzuela 199

UN (United Nations) 228; antiterrorism conventions 111; Convention on the Prevention and Punishment of Crimes against Internationally Protected Persons 113; Hague Convention (1970) 111-112; Hostages Convention 132; Interpol 169; Montreal Convention (1971) 112; terrorism 115-116; terrorism as unacceptable violence 172-181

uncivil disobedience 29-34

underinclusiveness, incidence test 63

UNHCR Handbook and Guidelines on Procedures and Criteria for Determining Refugee Status 205-206

United Arab Emirates, US-United Arab Emirates (2006) 194

United Kingdom (UK): controversies with US over terrorism (1980s) 146-51; political incidence test 57-9; Terrorism Act 2000 218; Terrorism Act 2006 218; US-UK treaty (2003) 196

United Nations Refugee Agency 48

United States see US 
Universal Declaration of Human Rights (UDHR) 53, 73

UN resolutions 5

UN Security Council 177; incitement of terrorism 219; September 2001187

US (United States); controversies with UK over terrorism (1980s) 146-151; Eain v. Wilkes 133-137; extradition 78-79; extradition agreement with EU (2003) 197; extradition treaties 4, 194-196, 204; incidence test 59-62; new understanding of terrorism 161-168; political crime 213; Reagan administration, POE loses justification 142-146; Reagan administration (US) 133; Supplementary Treaty (US and UK, 1985) 151-154; terrorism in the 80 s 137-142

US-Argentina treaty (1972) 90, 110

US-Austria treaty (1998) 90

US-Belgium extradition treaty (1882) 83

US-Belgium treaty (1882) 87-88

US-Brazil treaty (1961) 103, 110

US-Canada treaty (1971) 112-113

US-Colombia treaty (1888) 83

US courts, POE (political offence exception to extradition) 43

US draft convention (1972) 113-117

US-Ecuador extradition treaty (1872) 200

US extradition treaties; 1960-1970s 110-113; Belgian clause 164

US-France treaty (1996) 79, 165-167

US-FRG treaty (1978) 138-139

US-Germany extradition treaty (1930) 89-90

US-India extradition treaty (1997) 167-168

US-Israel extradition treaty 136

US-Italy treaty (1973) 112

US-Italy treaty (1983) 145
US-Jamaica treaty (1983) 145

US-Jordan treaty (1995) 164

US-Lithuania treaty (2001) 195

US-Mexico treaty (1899) 79

US-Morocco treaty (2013) 194

US-Poland treaty 167

USS Cole 162

US-Spain extradition treaty (1970) 111

US-Swiss extradition treaty (1990) 201

US-UK extradition treaty (1972) 152

US-UK treaty (1889) 84

US-UK treaty (2003) 196

US-United Arab Emirates (2006) 194

Van den Wijngaert, Christine 6-7, 13, $15,23,62,72,93,120,185,205$, 222,229

Venezuela 198-199

Vidal, Georges 97

violence: justified violence 208-209; political violence 30

Violent Crime Commonly Referred to as Terrorism 169

Volya, Narodnaya 96

V.P. Wassilieff 67

Walker, Clive 23

wanton crimes 206, 226

wanton crimes exception 134-135

warfare approach, to anti-terrorist actions 32

Webster-Ashburton treaty (1842) 42, 78,156

West Germany 139; Croissant 119-120

Whitley, Joe D. 198

Wight, Colin 22-23, 28, 34, 162, 186

WikiLeaks 200

Wilkinson, Paul 30

Winter 120

World Trade Center bombing (1993) 162, 216-217

Wouters, Jan 192-193 


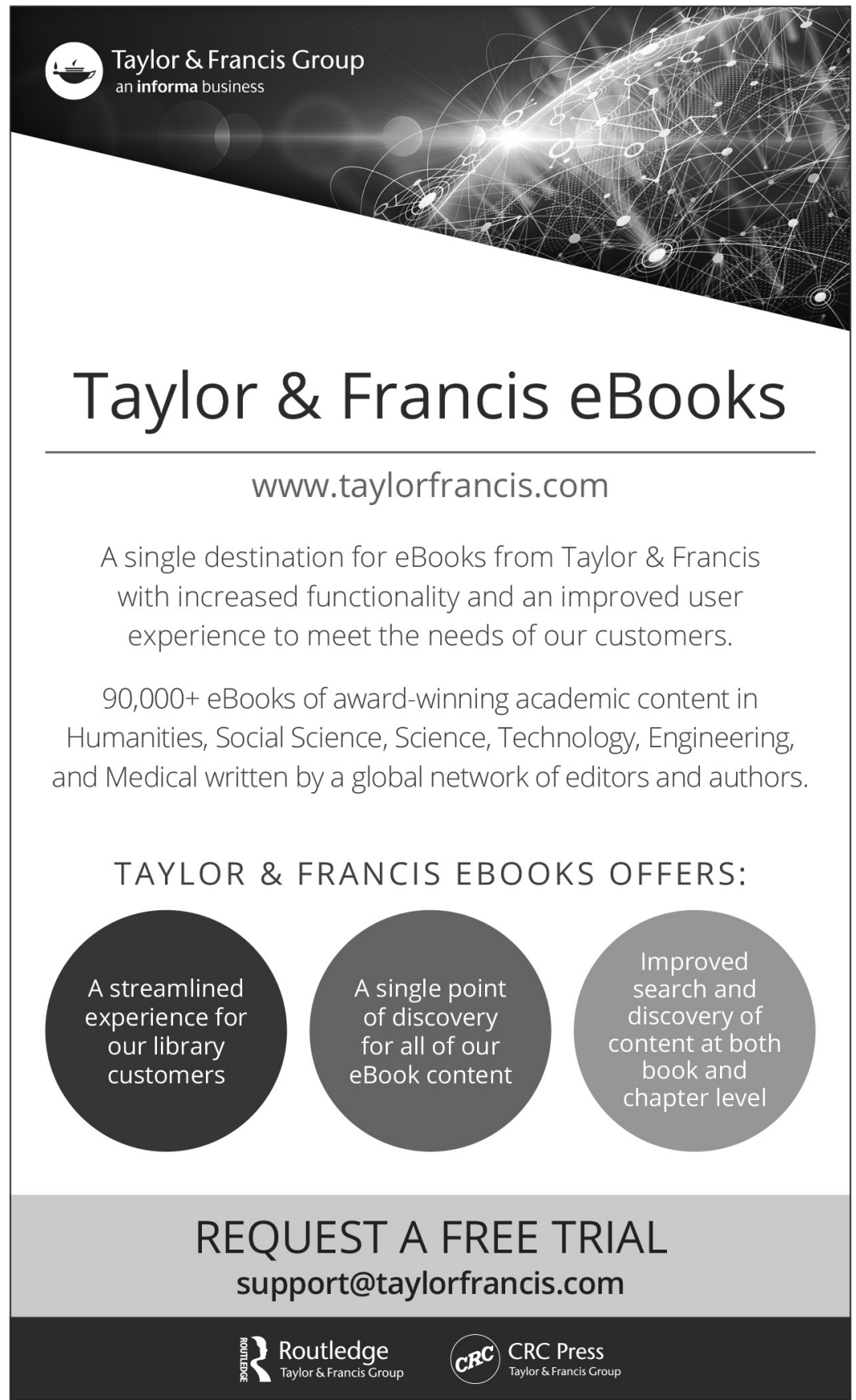

